\author{
UNIVERSIDADE DE SÃO PAULO \\ ESCOLA DE ENGENHARIA DE SÃO CARLOS \\ DEPARTAMENTO DE HIDRÁULICA E SANEAMENTO \\ CENTRO DE RECURSOS HÍDRICOS E ECOLOGIA APLICADA
}

Julia Myriam de Almeida Pereira

Avaliação biossocioeconômica das pescarias artesanais da represa de Barra Bonita (SP)

São Carlos, 2010 

Julia Myriam de Almeida Pereira

\title{
AVALIAÇÃO BIOSSOCIOECONÔMICA DAS PESCARIAS ARTESANAIS DA REPRESA DE BARRA BONITA (SP)
}

\author{
Tese apresentada à Escola de Engenharia de São Carlos da \\ Universidade de São Paulo como parte dos requisitos para obtenção \\ do título de Doutora em Ciências da Engenharia Ambiental.
}

Orientador: Prof. Dr. Miguel Petrere Júnior

São Carlos - SP

2010 
AUTORIZO A REPRODUÇÃO E DIVULGAÇÃO TOTAL OU PARCIAL DESTE TRABALHO, POR QUALQUER MEIO CONVENCIONAL OU ELETRÔNICO, PARA FINS DE ESTUDO E PESQUISA, DESDE QUE CITADA A FONTE.

Ficha catalográfica preparada pela Seção de Tratamento da Informação do Serviço de Biblioteca - EESC/USP

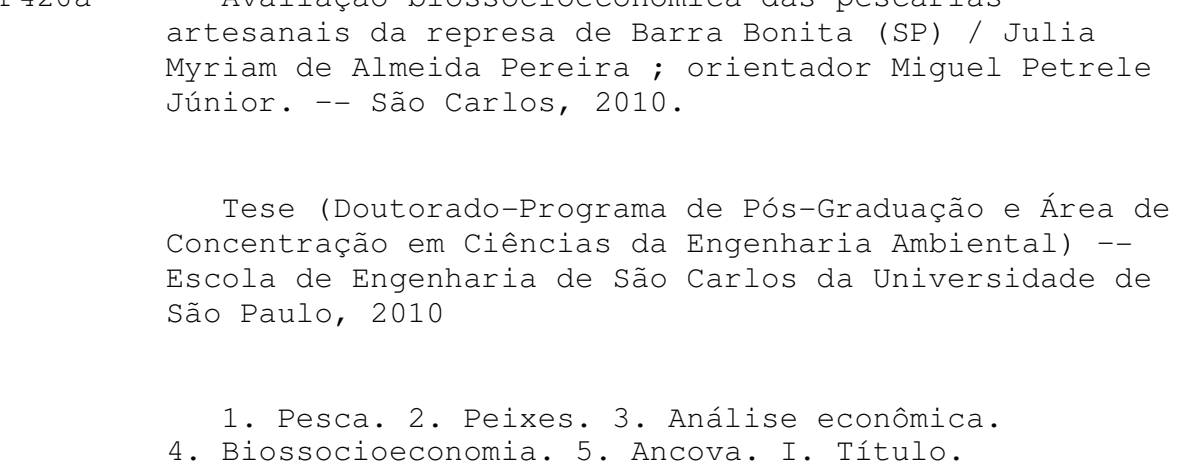

Tese (Doutorado-Programa de Pós-Graduação e Área de Concentração em Ciências da Engenharia Ambiental) -Escola de Engenharia de São Carlos da Universidade de São Paulo, 2010

1. Pesca. 2. Peixes. 3. Análise econômica. 4. Biossocioeconomia. 5. Ancova. I. Título. 
Candidato(a): Engenheiro JULIA MYRIAM DE ALMEIDA PEREIRA.

Tese defendida e julgada em 28.06.2010 perante a Comissão Julgadora:

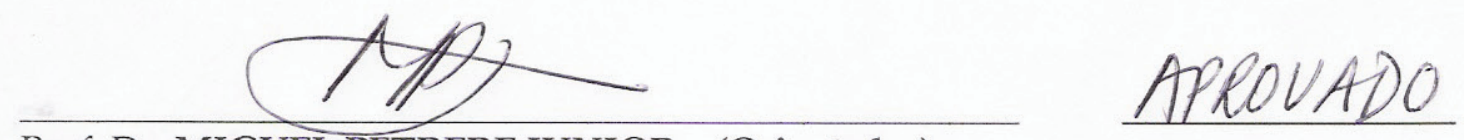

Prof. Dr. MIGUEL PETRERE JUNIOR - (Orientador)

(Universidade Estadual Paulista "Julio de Mesquita Filho"/UNESP/Campus de Rio Claro)

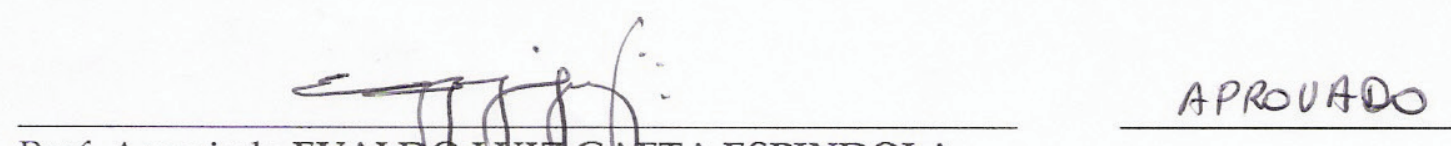

Prof. Associado EVALD $\phi$ wIt GAETA ESPINDOLA

(Escola de Engenharia de São Carlos/USP)

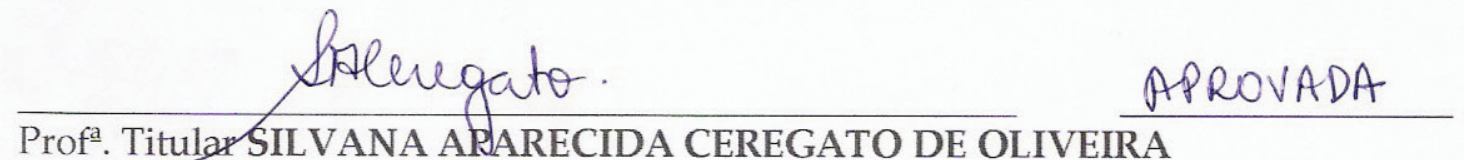
(Faculdades Integradas Claretianas/FIC)

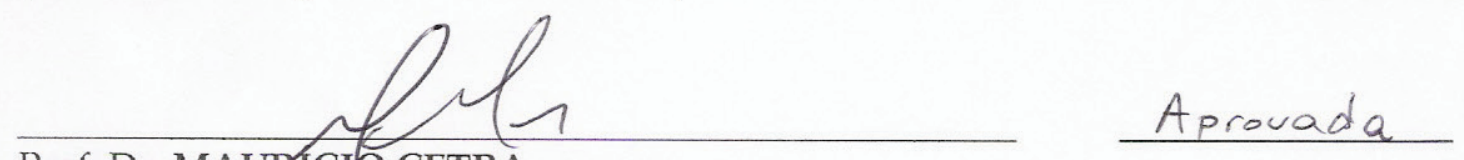

Prof. Dr. MAGRICIO CETRA

(Universidade Federat de São Carlos/UFSCar/Campus de Sorocaba)

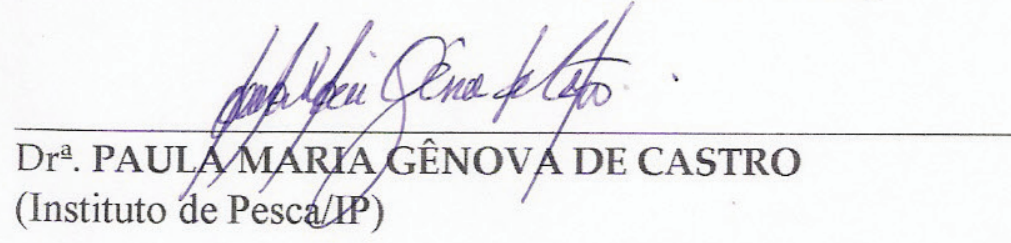

APEOVADA

(Instituto de PescallP)
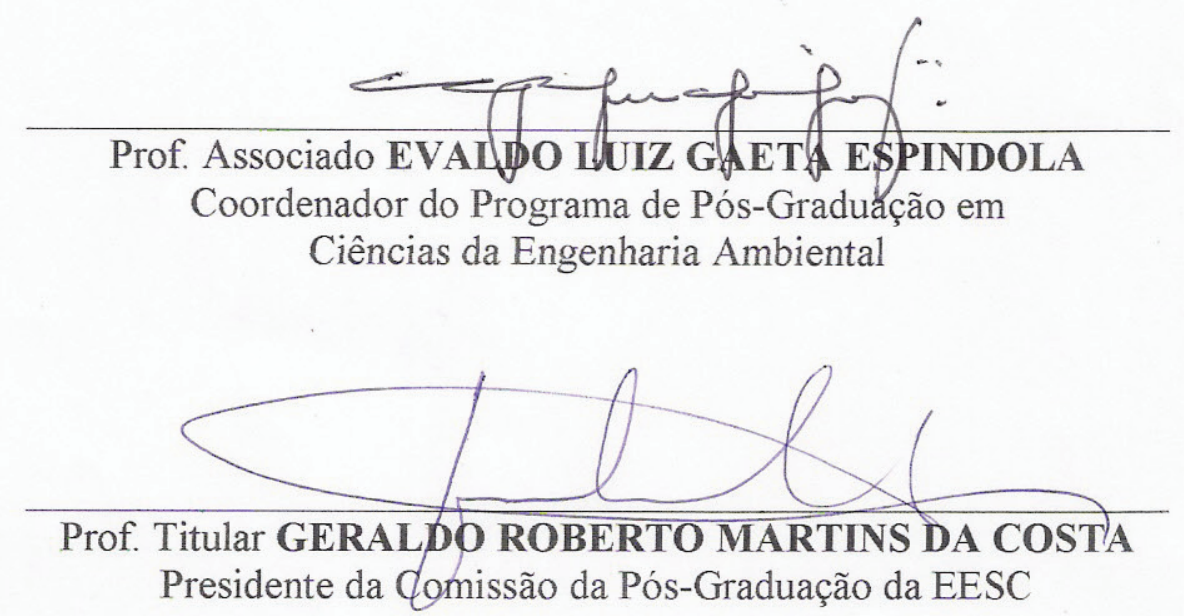

Ao meu querido professor Miguel Petrere

À minha amada Tia Zuleika 



\section{Agradecimentos}

Ao Conselho Nacional de Desenvolvimento Científico e Tecnológico pela concessão de bolsa de estudo durante o período de 12/2005 a 02/2009. À Coordenação de Aperfeiçoamento de Pessoal de Nível Superior pela concessão de bolsa no período de 03/2009 a 11/2009.

Ao Programa de Pós Graduação em Ciências da Engenharia Ambiental (Centro de Recurso Hídricos e Ecologia Aplicada - CRHEA) da Escola de Engenharia de São Carlos, Universidade de São Paulo.

Aos doutores Evaldo Luís Gaeta Espíndola, Paula Maria Gênova de Castro, Silvana Ceregato e Maurício Cetra por aceitarem examinar este trabalho.

Ao Dr. Evaldo Luís Gaeta Espíndola pelo convívio agradável, por todo o apoio e oportunidades oferecidas a mim durante ao longo destes anos.

Aos doutores Walter Barrela e Norma Felicidade Lopes da Silva Valêncio pelas valiosas sugestões em meu exame de qualificação.

À querida Claudete e ao Nelson por todo apoio e prontidão em me ajudar em todos os momentos.

Ao senhor Reinaldo José Spingolon por me acompanhar nos trabalhos de campo.

Aos meus pais, Joaquim e Regina pelo apoio e carinho que recebi. Aos meus irmãos Marcello, Andréia e Cecília, e aos meus cunhados Lucia, Ivan e Fábio. À Déia pelo apoio logístico na reta final.

Ao meu grande amor Rinaldinho pela paciência, companheirismo e apoio nos trabalhos de campo.

Ao meu filho Diogo, "o cara mais legal do planeta Júpiter" por ser um menino carinhoso e compreensivo e, do alto dos seus 5 anos, conseguir ter paciência para esperar a conclusão deste trabalho para eu poder me dedicar a ele como realmente merece.

E, finalmente, a grande questão: por que as diretrizes para apresentação deste trabalho não me deixam ter um prólogo? Se eu pudesse, ele seria mais ou menos assim:

“Em 1992 ingressei no curso de Ecologia, na UNESP de Rio Claro. O pouco contato que tive com o Miguel àquela época despertou meu respeito por toda a sua sabedoria $e$ conhecimento. Anos depois, virei "ecóloga desertora" fui para Recife cursar Engenharia de Pesca. O tempo passou e em 2002 eu estava lá em sua sala pedindo que me orientasse em meu mestrado. Aprendi bem mais do que "os mistérios das pescarias esportivas" e o uso das 
ferramentas estatísticas para sua análise, e descobri, além do respeito que já tinha, o querer bem. Ao final do meu mestrado, ele me acolheu para o desenvolvimento deste trabalho. Me ensinou sobre as pescarias artesanais, dinâmica de populações, lições da vida. Agora, ao final desta etapa, já sinto saudade do nosso, ainda que distante, convívio. Obrigada por sempre me orientar, ensinar, ajudar, e oferecer seu carinho e apreço à minha família. Peço desculpas por não ter, em alguns momentos, correspondido às suas expectativas. Mas agradeço, sobretudo, pela sua amizade. Obrigada, Miguel!" 


\section{Resumo}

Pereira, J.M.A. (2010). Avaliação biossocioeconômica das pescarias artesanais da represa de Barra Bonita (SP). Tese (Doutorado) - Escola de Engenharia de São Carlos, Universidade de São Paulo, São Carlos, 2010.

As pescarias artesanais ou de pequena escala são aquelas praticadas em embarcações de pequeno porte, com área de atuação restrita, cuja mão de obra é principalmente familiar. São comuns em águas continentais e o pescado capturado constitui importante fonte de proteína para as populações que delas dependem, além de garantir rendimentos econômicos ao pescador, apesar da presença de intermediários na comercialização do pescado. Os recursos pesqueiros da represa de Barra Bonita (SP) têm sustentado economicamente os pescadores do município e de outras regiões e considerou-se a hipótese de que a represa, por possuir características tróficas de qualidade de água intermediárias em relação à represa Billings (à montante) e ao Complexo de Urubupungá (à jusante), possui também produção pesqueira e lucratividade intermediárias. Os aspectos sociais, o cálculo de produção, esforço e renda foram determinados a partir da aplicação de questionários junto aos pescadores entre 2007 e 2008. As pescarias eram praticadas principalmente por homens jovens (entre 30 e 39 anos) que possuíam baixa escolaridade. A presença do intermediário se deu em várias dimensões: ora como fornecedor de alimentos, ora de insumos e também de petrechos, já que muitos dos pescadores não faziam distinção entre a figura do intermediário e do patrão. Além disso, houve menção à estreita dependência em relação também à moradia e à provisão de alimentos, atrelando fortemente a produção do pescador ao intermediário. A principal espécie capturada foi a tilápia e o modelo da ANCOVA indicou que a produção pesqueira dependeu das características fisiográficas e das oscilações provocadas pela sazonalidade. Houve diferença no volume de pescado capturado apenas entre as estações seca e cheia no braço do Rio Piracicaba, com as capturas mais elevadas na época chuvosa. Os estudos sobre os custos das pescarias indicaram que o principal componente é o combustível, apesar da pequena distância percorrida para suas pescarias. Os lucros são provenientes das capturas de tilápias, que embora não tenha alto valor comercial, assegura os rendimentos dos pescadores devido à sua a constância nas capturas. O modelo de ANCOVA mostrou que os lucros dependeram apenas do grau de instrução dos pescadores. Os pescadores indicaram o declínio do estoque pesqueiro e acreditavam que, se houvesse fiscalização eficiente, as pescarias predatórias (com petrechos fora dos padrões permitidos por lei) poderiam ser coibidas. Eles evidenciaram as condições a que foram relegados e seu desejo de evitar a marginalização da categoria. As políticas de manejo, em especial o co-manejo, deveriam assim considerar também este fator, tendo no pescador seu aliado para a manutenção da atividade e do meio ambiente.

Palavras chaves: pesca, peixes, análise econômica, biossocioeconomia, ANCOVA. 


\section{Abstract}

Pereira, J.M.A. (2010). Bio socio economic evaluation of artisanal fisheries of Barra Bonita reservoir (SP). Tese (Doutorado) - Escola de Engenharia de São Carlos, Universidade de São Paulo, São Carlos, 2010.

The artisanal or small scale fisheries are practiced in small reservoirs, with an operation area restricted and familiar labor. It's common in inland waters and the fish caught is an important source of protein for people who depend on them and provide economic returns to the fisher, despite the presence of intermediaries in the marketing of fish. The Barra Bonita reservoir (SP) have supported the fishers from other regions and we considered the hypothesis that Barra Bonita reservoir, because its trophic characteristics of water, intermediary in relation to the Billings (upstream) and the Complexo de Urubupungá (downstream), also has fisheries production and profitability intermediate. The social aspects, the yields, effort and income were derived from the application of questionnaires between 2007 and 2008. The analysis indicated that the fisheries were practices mostly by young men (between 30 and 39 years) who had little schooling. The presence of an intermediary was in several dimensions: sometimes he was the provider of food, sometimes supplies and also fishery equipments, and many fishers didn't made distinction between the figure of the intermediary and the employer. Furthermore, there was mention of the close dependence on the dwelling and also the provision of food, sticking strongly to the production of intermediate. The principal specie was tilapia and the ANCOVA model indicated that fish production depended on physiographic characteristics and fluctuations caused by seasonality. There were differences in the yields only during the dry season in the Piracicaba River, with higher catches during the rainy season. Studies on the fisheries' costs indicated that the main component is the fuel, despite the short distance to their fisheries. Profits are derived from the tilapia's yields, which no commercial value; ensure the income of fishers due to its constancy in the catch. The ANCOVA model showed that profits depend on the education level of fishers. Fishers indicated the decline of fish stocks and believed that if there was effective supervision, predatory fisheries could be curbed. Fishers showed the conditions to which they were relegated and his desire to avoid marginalization of the category. The management policies, especially the co-management, should therefore also consider this factor and its ally the fisher to maintain the activity and the environment.

Key words: fishery, fishes, economic analysis, bio socio economics, ANCOVA. 


\section{Lista de Figuras}

Figura 1: Represa de Barra Bonita (Fonte: http://www.earth.google.com)............................................... 6

Figura 2: Distribuição de faixa etária por gênero para os pescadores artesanais da represa de Barra Bonita..14

Figura 3: Distribuição de escolaridade por gênero para os pescadores artesanais da represa de Barra Bonita, onde (1) $\mathrm{EB}_{\text {incompleto }}=$ ensino básico incompleto; (2) $\mathrm{EB}_{\text {completo }}=$ ensino básico completo; (3) $\mathrm{EM}_{\text {incompleto }}=$ ensino médio incompleto; (4) $\mathrm{EM}_{\text {completo }}$ ensino médio completo; (5) SE= sem estudo; (6) $\mathrm{ES}=$ ensino superior completo.

Figura 4: Freqüência absoluta de dependentes dos pescadores que trabalham, com respectiva renda mensal média e dos que não trabalham.

Figura 5: Origem dos pescadores artesanais da represa de Barra Bonita $(n=102)$, com destaque para os pescadores oriundos do Estado de São Paulo $\left(n_{\text {total }}=59\right)$

Figura 6: Tempo de residência dos pescadores (anos) no entorno da represa de Barra Bonita. ......................17

Figura 7: Aspectos favoráveis e desfavoráveis apontados pelos pescadores artesanais de Barra Bonita ........17

Figura 8: Situação de moradia dos pescadores artesanais de Barra Bonita ................................................17

Figura 9: Freqüência absoluta dos animais criados pelos pescadores artesanais de Barra Bonita ...................19

Figura 10: Posse de bens de consumo indicados pelos pescadores de Barra Bonita......................................19

Figura 11: Abastecimento e tratamento da água consumida pelos dos pescadores de Barra Bonita...............20

Figura 12: Localização das instalações sanitárias e deposição do esgoto dos domicílios dos pescadores da represa de Barra Bonita

Figura 13: Deposição de resíduo sólido gerado pelos pescadores da represa de Barra Bonita. .......................21

Figura 14: Utilização das águas da represa de Barra Bonita pelos pescadores artesanais.................................22

Figura 15: Atendimento à saúde dos pescadores da represa de Barra Bonita ..............................................22

Figura 16: Assistência previdenciária dos pescadores da represa de Barra Bonita. .......................................23

Figura 17: Doenças contraídas pelos pescadores de Barra Bonita ou diagnosticadas....................................23

Figura 18: (A) Incidência de insetos e outros animais no entorno das moradias dos pescadores e (B) Ataque de animais peçonhentos aos pescadores da represa de Barra Bonita.

Figura 19: (A) Indicação da presença de animais silvestres, (B) Ataque de animais silvestres aos pescadores e

(C) Indicação do uso de animais silvestres pelos pescadores do entorno da represa de Barra Bonita......24

Figura 20: Indicação do uso de plantas da região pelos pescadores da represa de Barra Bonita. ....................25

Figura 21: Indicação da dieta alimentar dos pescadores da represa de Barra Bonita. ....................................25

Figura 22: Indicação da freqüência do consumo de peixe capturado pelos pescadores da represa de Barra Bonita.

Figura 23: Indicação da origem dos produtos hortifrutigrangeiros e de origem protéica consumidos pelos pescadores da represa de Barra Bonita. $p / p$ é a aquisição de produtos de patrões e/ou peixeiros .........26

Figura 24: Distribuição de captura absoluta por espécie $\left(Y_{w}, \mathrm{~kg}\right)$ da represa de Barra Bonita, onde dryLAKE= estação seca, zona lacustre; dryRP= estação seca, zona fluvial/braço Piracicaba; dryRT= estação seca, zona fluvial/braço Tietê; dryTRANS= estação seca, zona de transição; rainyLAKE= estação chuvosa, zona lacustre; rainyRP= estação chuvosa, zona fluvial/braço Piracicaba; rainyRT= estação chuvosa, zona fluvial/braço Tietê; rainyTRANS= estação chuvosa, zona de transição.

Figura 25: Distribuição das espécies capturadas $\left(Y_{w}, \mathrm{em} \mathrm{kg}\right)$ na represa de Barra Bonita, onde cada marca do eixo horizontal representa (1) estação seca, zona lacustre; (2) estação seca, zona fluvial/braço Piracicaba; (3) estação seca, zona fluvial/braço Tietê; (4) estação seca, zona de transição; (5) estação chuvosa, zona lacustre; (6) estação chuvosa, zona fluvial/braço Piracicaba; (7) estação chuvosa, zona fluvial/braço Tietê; (8) estação chuvosa, zona de transição.

Figura 26: (A) Análise de correlação entre os dados das capturas diárias (TOT_DIA) e a soma das capturas semanais (TOT_SEM), por espécie e (B) Análise de correlação entre os dados logaritimizados das capturas diárias (LNTD) e a soma das capturas semanais por espécie (LNTD).

Figura 27: Esforço de pesca (LNF, logaritmo do esforço pesqueiro em termos de número de dias de pescaria na semana) versus captura (LNY, logaritmo da captura em quilogramas).

Figura 28: Histograma dos resíduos do modelo final da ANCOVA $\ln y=\mu+S^{*} Z+\varepsilon$ para os dados agrupados das pescarias artesanais de Barra Bonita, onde $S^{*} Z$ é a interação entre (S) estações do ano (dry=seca, rainy=chuvosa) e (Z) zonas da represa ( $\mathrm{RP}=$ zona fluvial/braço Piracicaba, $\mathrm{RT}=$ zona fluvial/braço Tietê, TRANS= zona de transição e LAKE= zona lacustre) e $\varepsilon$ é o erro experimental ............49

Figura 29: (a) Locais de comercialização e (b) principais compradores do pescado capturado pelos pescadores artesanais da represa de Barra Bonita, onde dryLAKE= estação seca, zona lacustre; dryRP= estação seca, zona fluvial/braço Piracicaba; dryRT= estação seca, zona fluvial/braço Tietê; dryTRANS= estação seca, 
zona de transição; rainyLAKE= estação chuvosa, zona lacustre; rainyRP= estação chuvosa, zona fluvial/braço Piracicaba; rainyRT= estação chuvosa, zona fluvial/braço Tietê; rainyTRANS= estação chuvosa, zona de transição.

Figura 30: Formas de conservação do pescado da represa de Barra Bonita, onde dryLAKE= estação seca, zona lacustre; dryRP= estação seca, zona fluvial/braço Piracicaba; dryRT= estação seca, zona fluvial/braço Tietê; dryTRANS= estação seca, zona de transição; rainyLAKE= estação chuvosa, zona lacustre; rainyRP= estação chuvosa, zona fluvial/braço Piracicaba; rainyRT= estação chuvosa, zona fluvial/braço Tietê; rainyTRANS= estação chuvosa, zona de transição).

Figura 31: Distribuição dos custos semanais totais absolutos para as pescarias de Barra Bonita (Cfa= custo fixo semanal unitário do petrecho; $\mathrm{Cfe}=$ custo fixo semanal unitário da embarcação; Insumos=gasto semanal com gasolina e óleo para motor; Parceiro= pagamento semanal de parceiro/ajudante; dryLAKE= estação seca, zona lacustre; dryRP= estação seca, zona fluvial/braço Piracicaba; dryRT= estação seca, zona fluvial/braço Tietê; dryTRANS= estação seca, zona de transição; rainyLAKE= estação chuvosa, zona lacustre; rainyRP= estação chuvosa, zona fluvial/braço Piracicaba; rainyRT= estação chuvosa, zona fluvial/braço Tietê; rainyTRANS= estação chuvosa, zona de transição).

Figura 32: Distribuição dos custos semanais totais relativos para as pescarias de Barra Bonita (Cfa= custo fixo semanal unitário do petrecho; $\mathrm{Cfe}=$ custo fixo semanal unitário da embarcação; Insumos=gasto semanal com gasolina e óleo para motor; Parceiro= pagamento semanal de parceiro/ajudante; dryLAKE= estação seca, zona lacustre; dryRP= estação seca, zona fluvial/braço Piracicaba; dryRT= estação seca, zona fluvial/braço Tietê; dryTRANS= estação seca, zona de transição; rainyLAKE= estação chuvosa, zona lacustre; rainyRP= estação chuvosa, zona fluvial/braço Piracicaba; rainyRT= estação chuvosa, zona fluvial/braço Tietê; rainyTRANS= estação chuvosa, zona de transição).

Figura 33: Distribuição da renda bruta total de cada espécie (R\$) a partir da comercialização de peixes na represa de Barra Bonita, onde dryLAKE= estação seca, zona lacustre; dryRP= estação seca, zona fluvial/braço Piracicaba; dryRT= estação seca, zona fluvial/braço Tietê; dryTRANS= estação seca, zona de transição; rainyLAKE= estação chuvosa, zona lacustre; rainyRP= estação chuvosa, zona fluvial/braço Piracicaba; rainyRT= estação chuvosa, zona fluvial/braço Tietê; rainyTRANS= estação chuvosa, zona de transição.

Figura 34: (A) Análise de correlação entre os dados das rendas calculadas (RC) e as rendas declaradas (RD) pelos pesadores e (B) Análise de correlação entre os dados das rendas declaradas (RD) e das rendas calculadas (RC).

Figura 35: (a) Relação entre InL (logaritmo neperiano do lucro, em reais) e Inf (logaritmo neperiano do esforço, em termos de número de dias de pescaria por semana); (b) Relação entre InL (logaritmo neperiano do lucro, em reais) e Inl (logaritmo neperiano da idade dos pescadores, em termos de número de anos); (c) Relação entre InL (logaritmo neperiano do lucro, em reais) e InT (logaritmo neperiano da experiência dos pescadores, em termos de número de anos).

Figura 36: Histograma dos resíduos do modelo final da ANCOVA $\ln L=\mu+\ln +\varepsilon$ para os dados agrupados das pescarias artesanais de Barra Bonita, onde In é o grau de instrução dos pescadores e $\varepsilon$ é o erro experimental

Figura 37: Representação esquemática do Sistema Agroindustrial (SAG) do Pescado. Fonte: Sonoda (2006) .80

Figura 38: Problemas enfrentados pelos pescadores da represa de Barra Bonita. ..........................................87

Figura 39: (a) Situação do estoque pesqueiro da represa de Barra Bonita à época do estudo, e (b) Motivos para a redução.

Figura 41: Possíveis benefícios advindos da criação de uma Associação ou Cooperativa às margens da represa de Barra Bonita

Figura 42: Anseios dos pescadores da represa de Barra Bonita para a geração futura .................................89 
Lista de Tabelas

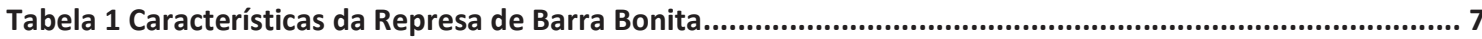

Tabela 2: Espécies de peixes encontradas na represa de Barra Bonita............................................................8

Tabela 3: Número entrevistas, de acordo com os locais visitados e zonas da represa de Barra Bonita. ..........13

Tabela 4. Freqüência absoluta do gênero dos pescadores artesanais da represa de Barra Bonita $\left(n_{\text {total }}=103\right) .13$

Tabela 5. Freqüência absoluta do estado civil dos pescadores artesanais da represa de Barra Bonita............14

Tabela 6: Tipo de material utilizado para a construção das residências dos pescadores artesanais da represa de Barra Bonita ( $n=102)$

Tabela 7: Fonte de energia e combustível de cocção.

Tabela 8: Freqüência relativa do uso da terra do entorno da represa de Barra Bonita para plantio e para criação de animais.

Tabela 9: Comparação entre a intensidade de pesca na represa de Barra Bonita, outras represas do Rio Tietê, represas do Brasil e de outras regiões tropicais.

Tabela 10: Estatísticas oficiais sobre a situação do saneamento (abastecimento de água canalizada, coleta de esgoto e coleta de lixo) dos municípios banhados pelas águas da represa de Barra Bonita e das zonas rural e urbana do estado de São Paulo (valores obtidos a partir de IBGE, 2010).

Tabela 11: Tempo de experiência na atividade pesqueira para os pescadores de Barra Bonita. . .40

Tabela 12: Especificações das embarcações e dos petrechos de pesca utilizadas pelos pescadores artesanais de Barra Bonita, com detalhamento da qualidade do material, propriedade e tamanho, de acordo com as estações do ano e as zonas da represa, onde RP= zona fluvial/braço Piracicaba; $R T=$ zona fluvial/braço Tietê; TRANS= zona de transição; LAKE= zona lacustre. RE é rede de espera, RA é rede de arrasto e PB é pesca de batida.

Tabela 13: Espécies de peixes encontradas na represa de Barra Bonita.

Tabela 14: Distribuição de captura ( $Y w$, em kg) total diária e total semanal na represa de Barra Bonita, onde RP= zona fluvial/braço Piracicaba; RT= zona fluvial/braço Tietê; TRANS= zona de transição; LAKE= zona lacustre.

Tabela 15: Distribuição das espécies capturadas $\left(Y_{w}, \mathrm{em} \mathrm{kg}\right)$ na represa de Barra Bonita, onde RP é a zona fluvial/braço Piracicaba; RT é zona fluvial/braço Tietê; Trans é a zona de transição; Lake é a zona lacustre.

Tabela 16: Esforço de pesca dos pescadores de Barra Bonita expresso em termos de número de horas por dia e número de dias por semana, onde RP= zona fluvial/braço Piracicaba; RT= zona fluvial/braço Tietê; TRANS= zona de transição; LAKE= zona lacustre.

Tabela 17: Resultados da ANCOVA aplicada no modelo $\ln c w=\mu+Z+S+Z * S+\ln f+\varepsilon$, onde $S$ é a estação do ano (dry=seca e rainy=chuvosa), $Z$ é a zona da represa (RT= zona fluvial/braço Tietê, RP= zona fluvial/braço Piracicaba, TRANS= zona de transição e LAKE=zona lacustre), $Z * S$ é interação de 1 ạ ordem, $\ln f$ é o logaritmo do esforço expresso em termos de dias de pescaria por semana.

Tabela 18 Teste a posteriori entre as médias de Iny (logaritmo neperiano da captura, em $\mathrm{kg}$ ) obtidas a partir do modelo final $\ln c w=\mu+Z * S+\varepsilon$. Comparação entre as zonas da represa (LAKE= zona lacustre; RP= zona fluvial/braço Piracicaba; RT= zona fluvial/braço Tietê; TRANS= zona da transição) em relação às estações do ano (seca e chuvosa). Os números entre parêntesis representam os antilogaritmos das médias ajustadas, em escala aritmética.

Tabela 19: Motivos para introduções de espécies de peixes exóticas e alóctones (Fonte: Holčík (1991).........53

Tabela 20: Comparação entre a intensidade de pesca em Barra Bonita, outras represas do Rio Tietê, represas do Brasil e de outras regiões tropicais..

Tabela 21 Equações utilizadas para os cálculos de custos, receita e lucro. .................................................62

Tabela 22: Levantamento dos custos das embarcações e dos petrechos utilizados pelos pescadores artesanais de Barra Bonita $(\mathrm{P}=$ preço unitário; $\mathrm{t}=$ tempo de vida útil; $\mathrm{D}=$ depreciação; $\mathrm{M}=$ custo de manutenção; $\mathrm{Cf}=$ custo fixo anual unitário; Cf sem= custo fixo semanal unitário. RP = zona fluvial/braço Piracicaba; $R T$ = zona fluvial/braço Tietê; Trans = zona de transição; Lake = ona lacustre.

Tabela 23: Custos variáveis das pescarias artesanais de Barra Bonita (In=gasto com gasolina, óleo para motor; Parc= pagamento de parceiro/ajudante; $\mathbf{C}$ sem= soma dos Insumos+Parceiro, por semana. $\mathbf{R P}=$ zona fluvial/braço Piracicaba; RT = zona fluvial/braço Tietê; Trans = zona de transição; Lake = zona lacustre.67 
Tabela 24: Valor de comercialização dos peixes capturados na represa de Barra Bonita, de acordo com a estação do ano e zona da represa. RP = zona fluvial/braço Piracicaba; RT = zona fluvial/braço Tietê; Trans = zona de transição; Lake = zona lacustre.

Tabela 25: Distribuição dos valores semanais da renda obtida pela comercialização dos peixes capturados pela pesca artesanal de Barra Bonita, onde dryLAKE= estação seca, zona lacustre; dryRP= estação seca, zona fluvial/braço Piracicaba; dryRT= estação seca, zona fluvial/braço Tietê; dryTRANS= estação seca, zona de transição; rainyLAKE= estação chuvosa, zona lacustre; rainyRP= estação chuvosa, zona fluvial/braço Piracicaba; rainyRT= estação chuvosa, zona fluvial/braço Tietê; rainyTRANS= estação chuvosa, zona de transição)

Tabela 26: Distribuição dos valores semanais da renda obtida pela comercialização dos peixes capturados pela pesca artesanal de Barra Bonita, onde dryLAKE= estação seca, zona lacustre; dryRP= estação seca, zona fluvial/braço Piracicaba; dryRT= estação seca, zona fluvial/braço Tietê; dryTRANS= estação seca, zona de transição; rainyLAKE= estação chuvosa, zona lacustre; rainyRP= estação chuvosa, zona fluvial/braço Piracicaba; rainyRT= estação chuvosa, zona fluvial/braço Tietê; rainyTRANS= estação chuvosa, zona de transição)

Tabela 27: Resultados da ANCOVA stepwise $\ln L=\mu+Z+S+E_{C}+\ln +E+P+\ln I+\ln T+\ln f+\varepsilon$ para os dados agrupados das pesarias artesanais, onde LNL a variável dependente (logaritmo do lucro), LNT, LNI e LNF as variáveis independentes (logaritmos do tempo de experiência, da idade e do esforço de pesca), e S, Z, EC, IN, E E P os fatores (estação do ano, zona da represa, estado civil, graus de instrução, material da embarcação e petrechos e artes de pesca).

Tabela 28: Teste a posteriori entre as médias de InL (logaritmo neperiano do lucro, em R\$) obtidas a partir do modelo final $\ln L=\mu+\operatorname{In}+\varepsilon$ os para os seis níveis de instrução (SE= sem estudo; $\mathrm{ES}=$ ensino superior completo; $\mathrm{EMc}=$ ensino médio completo; $\mathrm{EMi}=$ ensino médio incompleto; $\mathrm{EBc}=$ ensino básico incompleto; $\mathrm{EBi}=$ ensino básico completo)

Tabela 29: Comparação entre os custos fixos da pesca em Barra Bonita e outras represas do Rio Tietê do Brasil. 


\section{Conteúdo}

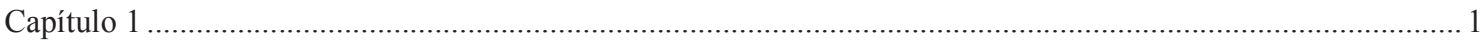

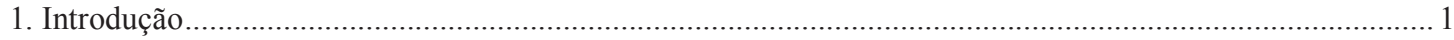

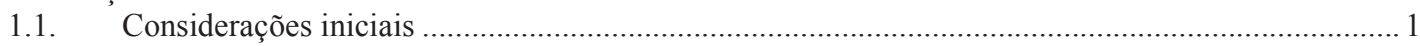

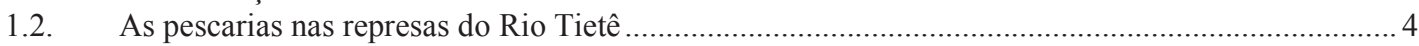

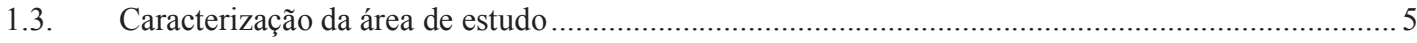

1.4. A fauna de peixes da represa de Barra Bonita .......................................................................

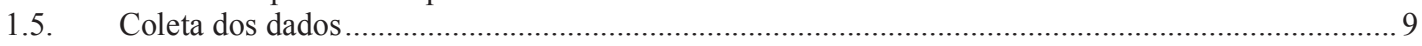

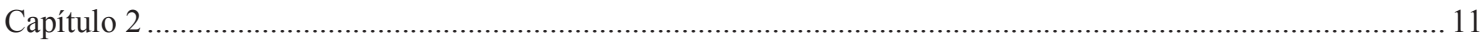

2. Aspectos sociais das pescarias artesanais da represa de Barra Bonita............................................................ 11

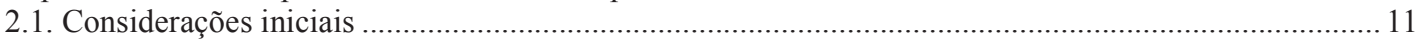

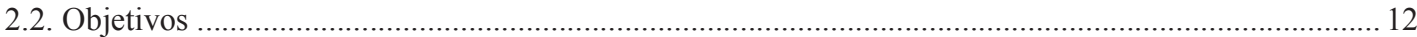

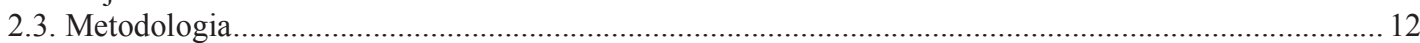

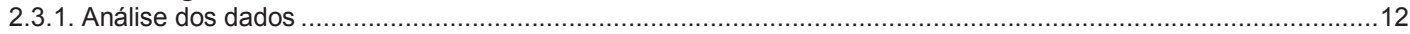

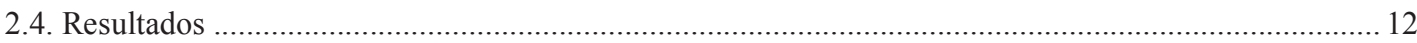

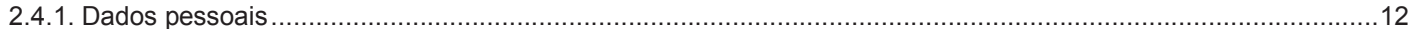

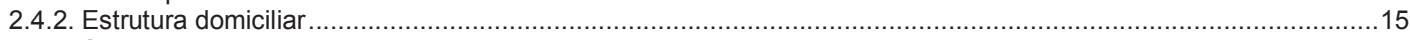

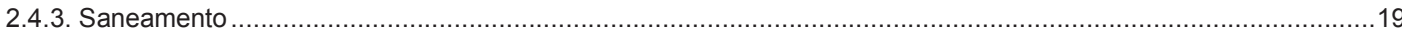

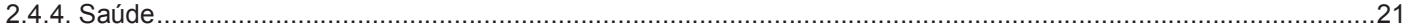

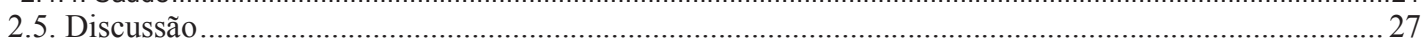

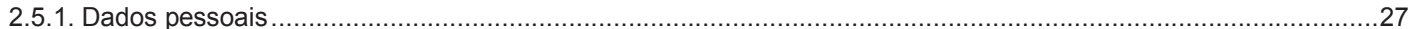

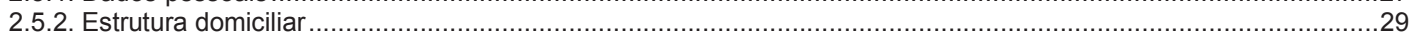

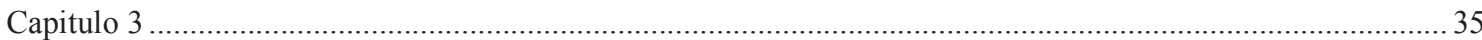

3. Caracterização das pescarias artesanais de Barra Bonita.................................................................... 35

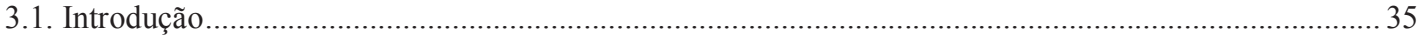

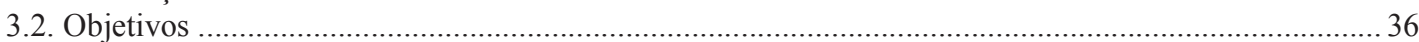

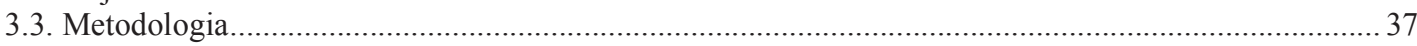

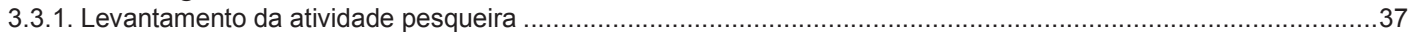

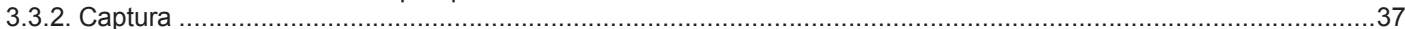

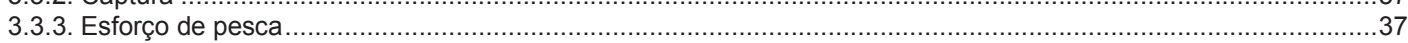

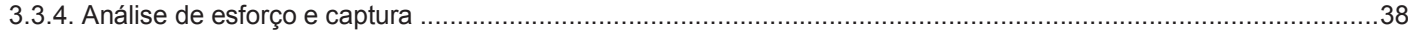

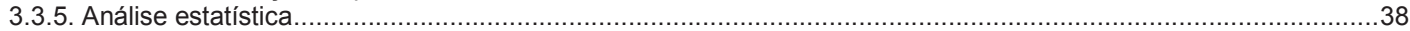

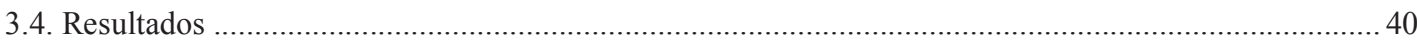

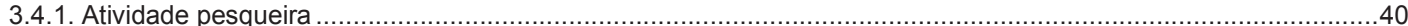

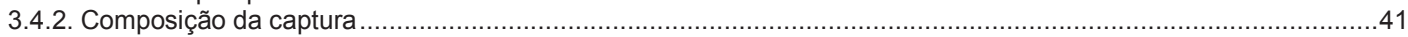

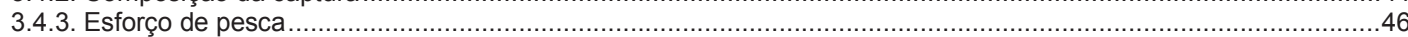

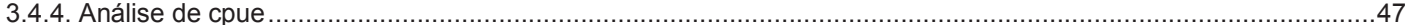

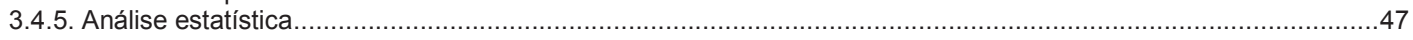

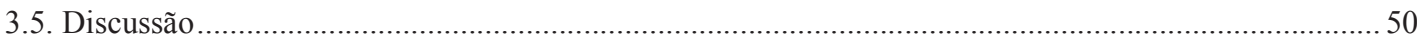

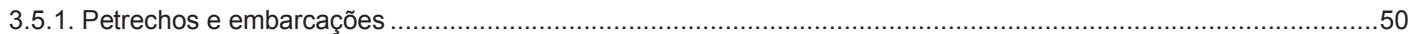

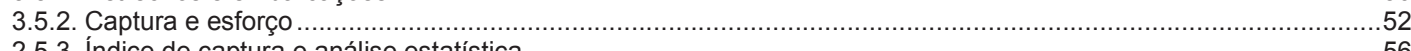

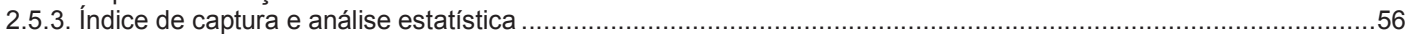

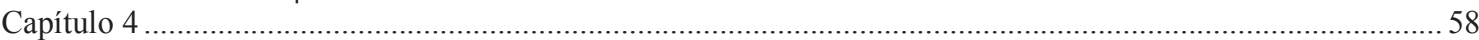

4. Estudo econômico das pescarias artesanais de Barra Bonita ............................................................. 58

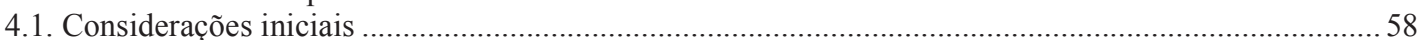

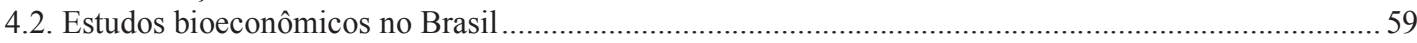

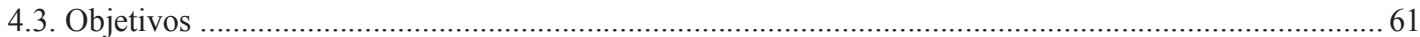

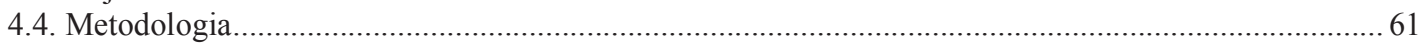

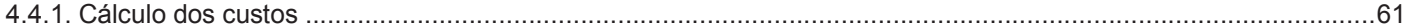

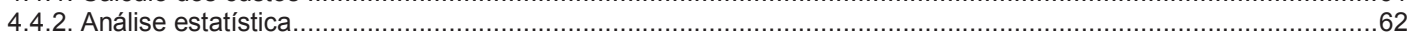

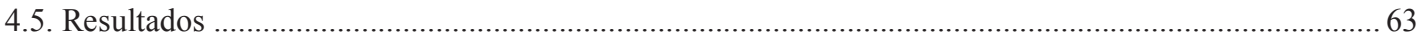

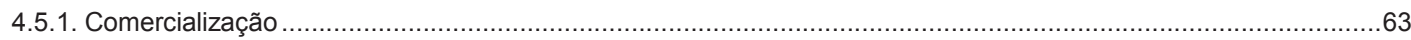

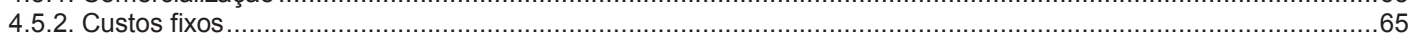

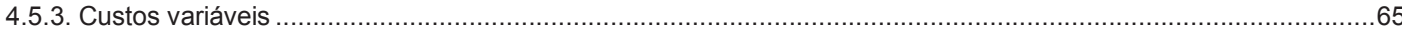

4.5.3.1. Remuneração de ajudante, conservação de pescado e gasto com combustível .....................................65

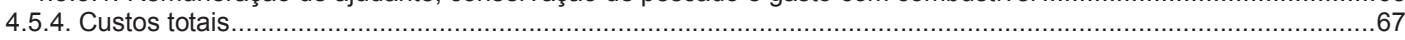

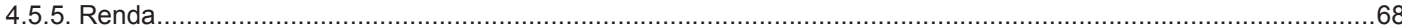

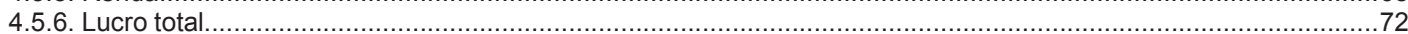

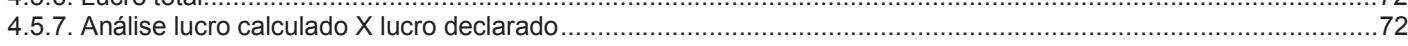

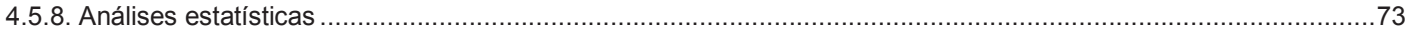

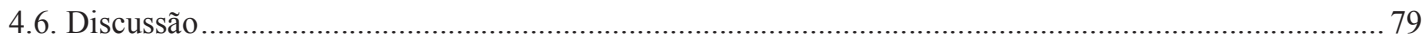

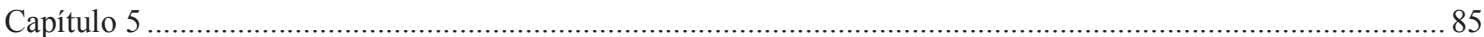

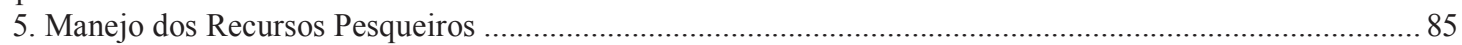




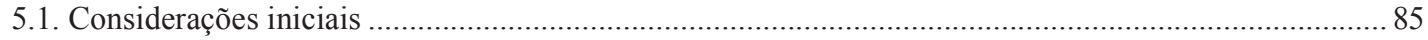

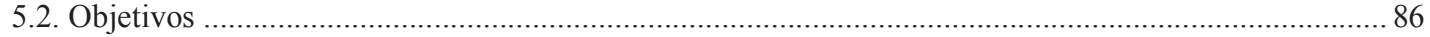

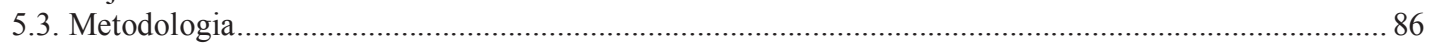

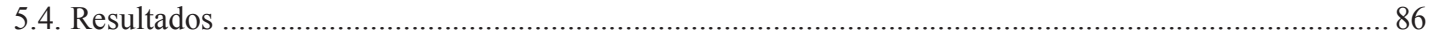

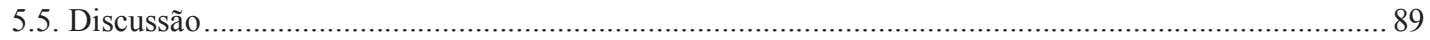

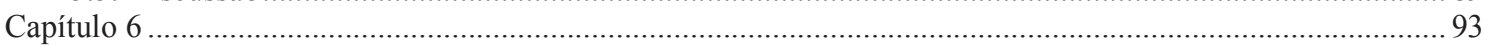

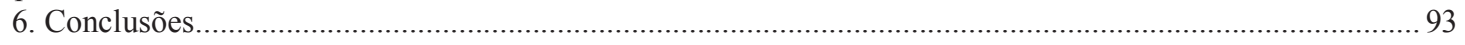

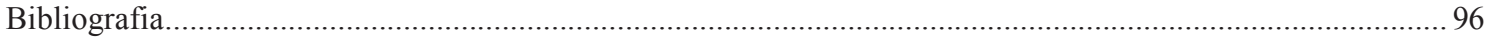

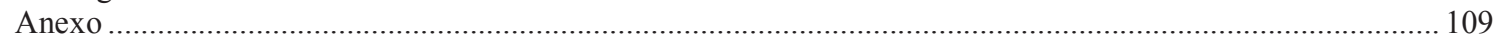




\section{CAPÍTULO 1}

\section{INTRODUÇÃO}

\subsection{CONSIDERAÇÕES INICIAIS}

As pescarias artesanais ou de pequena escala são aquelas praticadas em embarcações de pequeno porte, com área de atuação restrita (normalmente nas proximidades dos locais de desembarque pesqueiro), cuja mão de obra é principalmente familiar. As pescarias de pequena escala são comuns em águas continentais (Petrere et al., 2006) e o pescado capturado constitui importante fonte de proteína para as populações que delas dependem (Walter, 2000). Além disso, a atividade garante rendimentos econômicos ao pescador, apesar da presença de intermediários na comercialização do pescado (Bayley \& Petrere, 1989; Petrere, 1989).

Em 2007, a produção total de pescado no mundo foi em torno de 156,3 milhões de toneladas, sendo quase 41,1 milhões provenientes de capturas em águas continentais. No Brasil, a produção de pescado em 2007 foi de 1.072 .825 t, dos quais 454.453 t provenientes da pesca continental (FAO, 2009a). No Estado de São Paulo, as pescarias continentais artesanais perfizeram 10.089 toneladas, com rendimento econômico de $R \$ 28.596 .100,00$ (IBAMA, 2007).

A pesca artesanal em reservatórios e rios apresenta-se como atividade extrativa tradicional, com importantes repercussões sociais e ambientais. Os recursos pesqueiros, capazes de gerar elevados retornos econômicos m nível mundial, devem ser bem administrados. 0 
manejo da pesca, portanto, não está relacionado apenas ao estoque de peixes, mas também se devem considerar as necessidades sociais, econômicas e culturais da comunidade envolvida (Lucena, 2000). O manejo tradicional, baseado principalmente na conservação dos estoques, não tem atendido às novas expectativas, que incluem fatores econômicos, sociais e ambientais (King, 1995).

Straškraba e Tundisi (2000) consideram o gerenciamento da fauna íctica uma tarefa complexa, devendo ser consideradas as várias características da atividade pesqueira. A aplicação de questionários sócio-econômicos, baseados em estrutura familiar e infraestrutura do domicílio, podem ajudar a identificar as condições de vida e de trabalho dos pescadores e o perfil tecnológico da atividade (Mendonça, 1999). Conhecer a realidade sócio-econômica dos pescadores é de grande importância, tanto para a implementação de medidas de manejo de estoque pesqueiro quanto para o desenvolvimento econômico destas populações, e a análise de patrimônio é uma referência para a avaliação do padrão de conforto e qualidade de vida (Walter, 2000). Pereira (2005) acredita que a quantificação de bens pode ainda servir como um indicador indireto de renda quando não são disponíveis informações precisas sobre o montante recebido pelo pescador.

A retirada sistemática através da pesca pode ter diversas implicações na qualidade da água e a quantificação da biomassa de peixes pode servir como indicativo ou controle das condições limnológicas de uma represa (Gulati, 2001).

Para Tundisi (1999), os reservatórios proporcionam benefícios como reserva de água para hidroeletricidade, irrigação, navegação e água para abastecimento público e vários rios brasileiros foram aproveitados para a construção de barragens em cascata. O sistema de reservatórios em cascata, como é o caso do rio Tietê, retém material particulado, nitrogênio e fósforo, atuando como lagoas e possibilitando melhora na água (Petrere et al., 2002; Petrere, 1996).

No Brasil, a ictiofauna que compõe os grandes reservatórios é proveniente tanto dos tributários como das espécies introduzidas (Welcomme, 1988). Destas, há as exóticas que são originárias de outros continentes e as alóctones, originárias de outras bacias hidrográficas, do mesmo continente (Walter, 2000).

A atividade pesqueira em águas interiores tem se mostrado importante, no que se refere à população que dela sobrevive e ao manejo dos ecossistemas de água doce. Assim, o monitoramento de pescarias artesanais pode oferecer respostas para a avaliação dos 
recursos pesqueiros, através da aplicação de questionários (Castro, 1992; Camargo \& Petrere, 2001). As pescarias são sistemas bio-socio-econômicos complexos e os aspectos biológicos são os mais estudados. As avaliações econômicas são importantes para compreender o comportamento dos pescadores artesanais e a maneira como as políticas de manejo de recursos pesqueiros os afeta (Petrere et al., 2006).

Um estudo sobre a situação atual da pesca na represa de Barra Bonita pode ainda fornecer subsídios para manejo da população de peixes, melhorando a qualidade da captura e da água do reservatório (Agostinho et al., 1999). A aplicação de questionários é um importante instrumento para propostas de manejo da atividade pesqueira e aperfeiçoamento das formas de comercialização do pescado, com possível agregação de valor ao produto final, melhorando as condições sócio-econômicas da população (Walter, 2000).

Além disso, os recursos pesqueiros da represa de Barra Bonita têm sustentado economicamente os pescadores do município e de outras regiões, como por exemplo, aqueles que pescavam anteriormente na represa Billings (Petrere et al., 2006).

Considerou-se a hipótese de que a represa de Barra Bonita, por possuir características tróficas de qualidade de água intermediárias em relação à represa Billings (à montante) e ao Complexo de Urubupungá (à jusante), possui também produção pesqueira e lucratividade intermediárias. Um dos objetivos desta tese é o de compreender se na represa de Barra Bonita, analogamente, as produções pesqueiras e lucros têm diferenças entre as zonas fluvial, transição e lacustre, comparando os aspectos sócio-econômicos das pescarias profissionais de pequena escala entre as zonas fluvial, transição e lacustre da represa de Barra Bonita.

Este estudo será apresentado em seis capítulos. Neste primeiro as pescarias artesanais do Rio Tietê, a represa de Barra Bonita e sua ictiofauna são apresentadas. O segundo capítulo caracteriza os aspectos sociais das pescarias artesanais e no terceiro os resultados desta atividade são descritos. Um estudo econômico dos resultados destas pescarias é apresentado no capítulo quatro. O quinto capítulo utiliza os resultados expostos nos capítulos anteriores como ferramentas para discutir o manejo de recursos pesqueiros. 0 sexto capítulo, finalmente, expõe as considerações finais e as recomendações deste trabalho. 


\subsection{AS PESCARIAS NAS REPRESAS DO RIO TIETÊ}

As pescarias praticadas ao longo do rio Tietê eram, antes dos represamentos, voltadas para as capturas de espécies migradoras de grande porte (Petrere et al, 2002). De acordo com Agostinho et al. (2007) as capturas nas represas construídas ao longo do rio Tietê (considerando as represas de Billings, Barra Bonita, Ibitinga, Promissão e Três Irmãos) variam muito entre os anos, fato relacionado à diminuição do grau de trofia de suas águas.

Os pescadores utilizam redes de emalhar ou malhadeira (gillnet) como principal petrecho e tem apoio de Colônias de Pesca distribuídas ao longo do rio Tietê. Nas épocas de baixo rendimento costumam migrar entre as represas (Torloni et al, 1993).

Embora não represe águas do rio Tietê, a represa Billings é abastecida com águas de rios da bacia do Alto Tietê. As pescarias da represa Billings foram estudadas por Minte-Vera (1997) e, à época, eram praticadas por 101 pescadores artesanais, cuja captura principal era de tilápia (Oreochromis niloticus, 81,4\% das capturas), retorno econômico diário de $\mathrm{R} \$ 17,75$ por pescador e rendimento médio de $572 \mathrm{~kg} /$ pescador/mês. Estas pescarias entraram em declínio devido ao aumento da violência na região metropolitana de São Paulo e muitos dos pescadores que atuavam nesta represa agora se encontram a jusante, na represa de Barra Bonita (Petrere et al., 2006). O declínio das pescarias artesanais também foi apontado em relação ao número de pescadores e ao rendimento pesqueiro a partir de 2008 , quando a produtividade foi estimada em 16,2 kg/ha/ano, cujas capturas principais foram de cará (Geophagus brasiliensis, 42,9\% das capturas), tilápia (25,2\%) e lambari (Astyanax sp, 16,3\%) (Silva, 2008).

As pescarias profissionais da represa de Barra Bonita foram estudadas por Torloni et al. (1993) através de entrevistas com uma média de 30 pescadores ativos à época, sobre as capturas provenientes da pesca com redes de emalhar em cinco núcleos de pesca localizados nos braços dos rios Tietê e Piracicaba. Nestes locais, Carvalho Jr. et al. (1995) também entrevistaram uma média de 31 pescadores profissionais sobre as capturas com redes de emalhar e relataram a captura de 41 espécies de peixes. Silvano \& Begossi (1998) estudaram as pescarias profissionais em dois locais de captura no Braço Piracicaba (Ponte de Santa Maria da Serra e Tanquã), quando os pescadores capturaram $8382 \mathrm{~kg}$ de peixes pertencentes a 43 espécies. A organização social dos pescadores do bairro Tanquã se baseia no associativismo familiar e a comunidade tem observado a diminuição das espécies de peixes, o desaparecimento de espécies de maior valor comercial e a presença de pescadores 
considerados clandestinos (pescadores que atuam em outras regiões da represa) (Venturato, 2008). As pescarias artesanais de Barra Bonita foram estudadas em duas etapas por Maruyama (2007) (2001 e 2003/04), cujas maiores capturas foram de tilápia (88,9\% do total), declínio da cpue (captura por unidade de esforço) (1652 e 959 kg/pescador/mês, respectivamente) e aumento do rendimento (595,2 e 1186 toneladas/ano, respectivamente) entre os períodos.

Em 1993 foi registrada a cpue de $327 \mathrm{~kg} /$ pescador/mês e produtividade de 37 toneladas/ano no reservatório de Ibitinga (dados compilados por Petrere et al., 2002). Maruyama (2007) calculou a cpue de 353,6 e 368,1 kg/pescador/mês em 2001 e 2003/04, respectivamente, cujas principais capturas foram de corvina (Plagioscium squamosissimus, $24,87 \%)$ e tilápia $(23,91 \%)$.

As pescarias da represa de Promissão obtiveram índice de cpue de 888 kg/pescador/mês e produtividade de 222 toneladas/ano em 1993 (dados compilados por Petrere et al., 2002). As cpues oscilaram entre 827,5 e 651,6 kg/pescador/mês entre 2001 e 2003/04, respectivamente e as espécies mais capturadas foram mandi (Pimelodus maculatus, 27,27\%), campineiro (Schizodon nasutus, 21,75\%) e corvina (17,75\%) (Maruyama, 2007).

Os rendimentos econômicos das pescarias artesanais do Complexo de Urubupungá (usinas hidrelétricas de Ilha Solteira, Jupiá e Três Irmãos/ represa de Jupiá, formada pelos rios Paraná, Sucuriú e Tietê - o último trecho do sistema de cascatas - e represa de llha Solteira, no rio Paraná) foram avaliados por Ceregato \& Petrere (2003) e o rendimento econômico diário por pescador foi de $\mathrm{R} \$ 13,19$ e $\mathrm{R}$ \$ 19,54 para as estações seca e chuvosa, respectivamente. Maruyama (2007) estimou as cpues para 2001 e 2003/04 em 720,8 e 593,7 $\mathrm{kg} /$ pescador/mês para a represa de Três Irmãos, com captura de corimba (Prochilodus lineatus, 31,24\%), porquinho (Geophagus surinamensis, 20,35\%) e corvina (18,99\%), principalmente.

\subsection{CARACTERIZAÇÃO DA ÁREA DE ESTUdO}

O rio Tietê atravessa praticamente todo o território paulista, desde a Serra do Mar até o rio Paraná. Desemboca no Alto Paraná, a jusante do salto de Urubupungá, afogado pela barragem de Jupiá, que represa também as águas do Tietê nos seus últimos 
quilômetros de percurso. O comprimento total do rio é de 1,15 mil km e seu desnível entre a desembocadura e as cabeceiras é de cerca de $860 \mathrm{~m}$. O grande desnível de seu curso foi aproveitado para construção de várias barragens destinadas à produção de energia hidrelétrica.

A represa de Barra Bonita (latitude $22^{\circ} 29^{\prime}$ S e longitude $48^{\circ} 33^{\prime} \mathrm{W}$ ) (Figura 1), situada entre os municípios de Barra Bonita e Igaraçu do Tietê, foi construída a partir do represamento do Rio Tietê (Calijuri e Tundisi, 1990), embora também represe a parte baixa do rio Piracicaba, importante afluente da margem direita. Sua construção teve início em 1954, com o objetivo de fornecer energia hidrelétrica e atualmente suas águas também são utilizadas para irrigação, pesca, turismo, abastecimento urbano e industrial e navegação, possibilitada pelo funcionamento de uma eclusa (ANEEL, 2006) (Tabela 1). Na bacia da represa de Barra Bonita são desenvolvidas atividades industriais, principalmente têxteis, alimentícias, de papel e papelão e usinas de açúcar e álcool (CETESB, 2001), atividades que aceleram o processo de eutrofização da represa (Petracco, 1995). A vegetação dominante, ao seu redor, é a monocultura intensiva de cana de açúcar, seguida de pastagens cultivadas (Petesse, 2006).

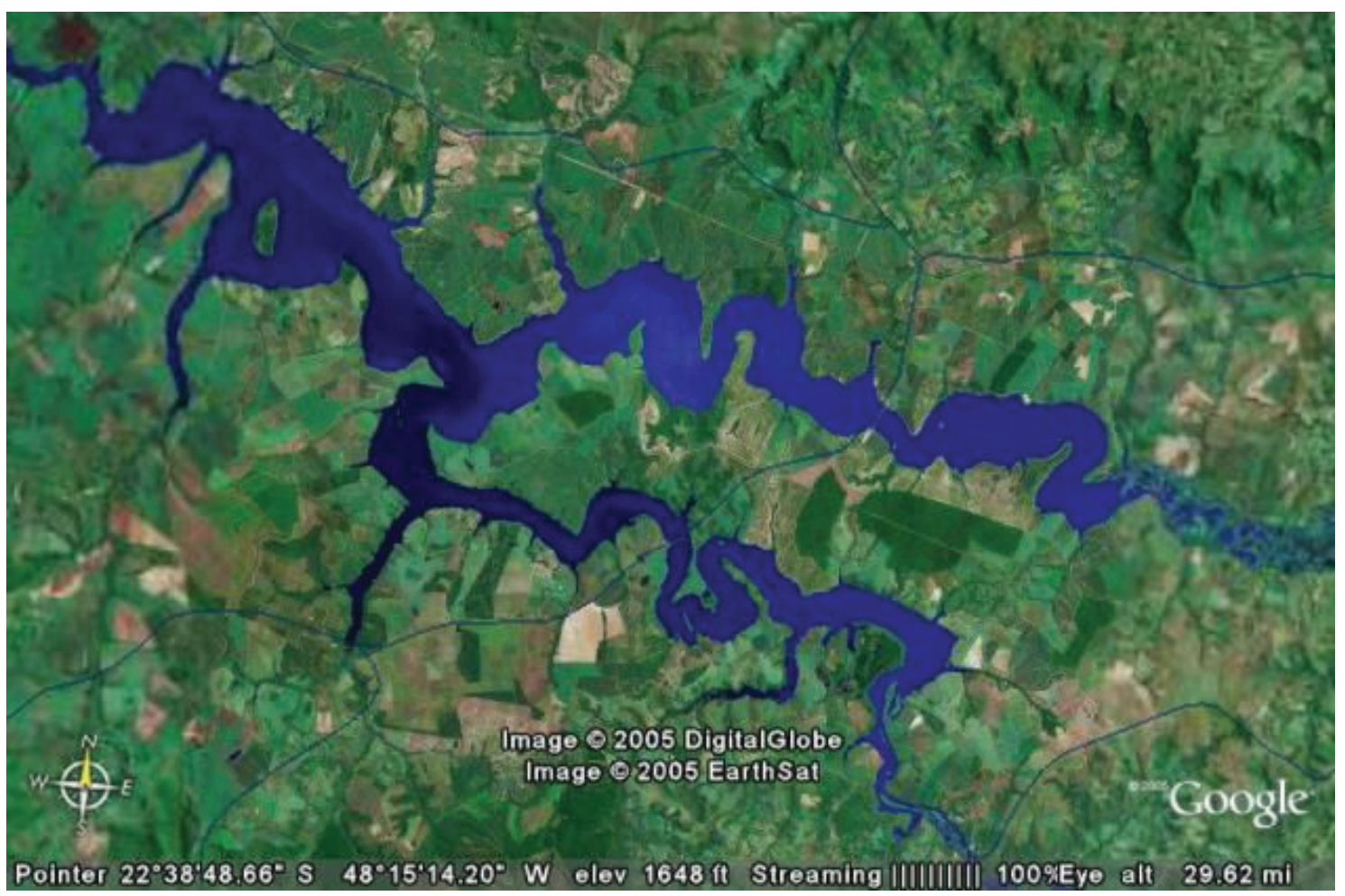

Figura 1: Represa de Barra Bonita (Fonte: http://www.earth.google.com) 


\begin{tabular}{|c|c|}
\hline Local & Município de Barra Bonita \\
\hline Rios formadores & Rio Tietê e Rio Piracicaba \\
\hline Altitude & $430 \mathrm{~m}$ \\
\hline Potência & $140 \mathrm{MW}$ \\
\hline Comprimento da barragem & $287 \mathrm{~m}$ \\
\hline Área da bacia & $32.330 \mathrm{~km}^{2}$ \\
\hline Área do lago (cota máxima) & $310 \mathrm{~km}^{2}$ \\
\hline Volume útil acumulado & $2566 \times 10^{6} \mathrm{~m}^{3} / \mathrm{s}$ \\
\hline Início das operações & 1963 \\
\hline Cota máxima útil & $451,5 \mathrm{~m}$ \\
\hline Cota mínima útil & $439,5 \mathrm{~m}$ \\
\hline Profundidade média & $10,1 \mathrm{~m}$ \\
\hline Propósitos & $\begin{array}{l}\text { Geração de energia, navegação, irrigação, recreação, pesca, turismo, } \\
\text { abastecimento urbano e industrial da região }\end{array}$ \\
\hline Classificação trófica & Eutrófica \\
\hline
\end{tabular}

De acordo com Petesse (2006), a represa é constituída por (a) dois braços ao longo dos principais tributários (rios Tietê e Piracicaba); (b) um corpo central que compreende a planície aluvial e (c) várias enseadas devidas a tributários de pequeno porte.

\subsection{A FAUNA DE PEIXES DA REPRESA DE BARRA BONITA}

Petesse (2006) realizou detalhados estudos sobre a ecologia das comunidades de peixes através de pescarias experimentais com redes de emalhar e covos e capturou 35 espécies de peixes em 24 locais de pescaria. Das espécies capturadas, quatro eram alóctones (acará geo, Satanoperca jurupari e corvina, Plagioscion squamosissimus, ambas da Bacia Amazônica; pacu peva, Metynnis maculatus e cascudo, Liposarcus anisitsi, ambas de outras bacias) e uma exótica (tilápia, Oreochromis niloticus - África). Além destas e das espécies nativas, foram mencionados os peixamentos realizados pela CESP (Companhia Energética Estado de São Paulo) na década de 1970, quando foram introduzidas: sardinha (Triportheus a. angulatus=T. signatus, bacia rio Parnaíba), corvina, apaiari (Astronotus ocellatus), tucunaré (Cichla ocellaris) (Bacia Amazônica) e tilápia, O. hornorum (África). Algumas destas não aparecem nas pescarias profissionais ou experimentais desde 1989, indicando provável insucesso do processo de colonização. Atualmente, o programa de peixamento, realizado pela Estação de Aqüicultura e Hidrobiologia de Promissão, prevê a introdução em Barra Bonita de 235.000 alevinos por ano apenas de "espécies nativas" (Petesse, op. cit.) (Tabela2). 
Tabela 2: Espécies de peixes encontradas na represa de Barra Bonita.

\begin{tabular}{|c|c|c|c|}
\hline Ordem & Família & Nome científico & Nome vulgar \\
\hline \multirow[t]{23}{*}{ Characiformes } & Anostomidae & Leporinus lacustris & Corró, piava de lagoa \\
\hline & & Leporinus obtusidens & Piapara \\
\hline & & Schizodon intermedius & Piava, campineiro \\
\hline & & Schizodon fasciatus & Piava \\
\hline & & Schizodon nasutus & Ximboré \\
\hline & Acestrorhynchidae & Acestrorbynchus lacustris & Peixe-cachorro \\
\hline & Characidae & Astyanax altiparanae & Tambiú \\
\hline & & Astyanax fasciatus & Lambari de rabo vermelho \\
\hline & & Astyanax schubarti & Lambari prateado \\
\hline & & Moenkhausia intermedia & Viuvinha, lambari corinthiano \\
\hline & & Salminus bilarii & Tabarana \\
\hline & & Triportheus paranensis & Sardinha de água doce \\
\hline & & Hyphessobrycon eques & Mato-grosso \\
\hline & & Piaractus mesopotamicus & Pacu \\
\hline & & Serrasalmus maculatus & Piranha \\
\hline & & Serrasalmus spilopleura & Piranha, Pirambeba \\
\hline & & Metynnis maculatus & Pacu-peva \\
\hline & & Cyphocharax modestus & Saguiru de rabo vermelho \\
\hline & & Cyphocharax nagelii & Saguiru de rabo amarelo \\
\hline & & Steindachnerina insculpta & Saguiru-branco \\
\hline & Erythrinidae & Hoplias malabaricus & Traíra, Lobo \\
\hline & Parodontidae & Apareidon piracicabae & Canivete \\
\hline & Prochilodontidae & Prochilodus lineatus & Corimba \\
\hline \multirow[t]{6}{*}{ Siluriformes } & Callichthyidae & Hoplosternum littorale & Caboja, caborja \\
\hline & Loricariidae & Liposarcus anisitsi & Cascudo \\
\hline & Loricariidae & Hypostomus ancistroides & Cascudo (ancistroide) \\
\hline & Pimelodidae & Pimelodus maculatus & Mandi-amarelo \\
\hline & Heptapteridae & Pimelodella sp. & Mandi-chorão \\
\hline & Heptapteridae & Rhamdia quelen & Bagre \\
\hline Gymnotiformes & Gymnotidae & Gymnotus carapo & Tuvira \\
\hline \multirow[t]{5}{*}{ Perciformes } & Cichlidae & Crenicichla haroldoi & Joaninha \\
\hline & & Geophagus brasiliensis & Acará, Cará \\
\hline & & Satanoperca jurupari & Acará geo \\
\hline & & Oreochromys niloticus & Tilápia do Nilo \\
\hline & Scianidae & Plagioscion squamosissimus & Corvina, Pescada \\
\hline
\end{tabular}

Barrella e Petrere (2003), através de pescarias experimentais com redes de emalhar em cinco locais de captura, estudaram as alterações da comunidade de peixes devido à poluição e ao represamento e encontraram 34 espécies; os autores ressaltaram ainda a maior produtividade pesqueira em relação a outras represas do Médio e Baixo Tietê.

Smith et al. (2002) abordaram a composição e distribuição das espécies de peixes na represa de Barra Bonita através de pescarias experimentais (redes de emalhar, peneiras, puçás e rede de arrasto) e os autores consideraram a ictiofauna composta por 60 espécies.

Freitas \& Petrere (2001) testaram o efeito da introdução de recifes artificiais na represa sobre as comunidades de peixes e verificaram que as capturas e a diversidade foram maiores em regiões próximas aos recifes, em relação às áreas controle, como esperado. 
Castro (1994) registrou a presença de 35 espécies em três locais de captura. A diferença entre os números de espécies citados deve-se às diferentes abordagens dos trabalhos.

A comunidade de peixes e os recursos alimentares em regiões litorais foram estudados por Smith et al. (2003). Sobre a biologia das espécies de peixes, foram desenvolvidos os estudos:

(i) Viuvinha (Moenkhausia intermedia): fecundidade, desova e mortalidade natural (Braga \& Gennari Filho, 1991); alimentação (Costa \& Braga, 1993); fecundidade e desova (Gennari \& Braga, 1996);

(ii) Tambiú (Astianax bimaculatus = A. altiparanae): alimentação (Costa \& Braga, 1993);

(iii) Lambari prateado (A. schubarti): alimentação (Costa \& Braga, 1993); fecundidade e desova (Gennari \& Braga, 1996); idade, crescimento e taxas de mortalidade (Braga, 1999);

(iv) Corvina: aspectos ecológicos da comunidade e a dinâmica populacional (Castro, 1994); biologia reprodutiva de corvina (Braga, 1997); alimentação (Braga, 1998).

\subsection{COLETA DOS DADOS}

Foram realizadas visitas aos núcleos de pescaria no intuito de estabelecer um primeiro contato com os pescadores e realizar pré-amostragens. Na medida em que os pescadores foram sendo entrevistados, foi pedido que indicassem outros pescadores a serem contatados, e assim sucessivamente, utilizando-se o procedimento "bola de neve" (IBAMA/DNOCS/GTZ, 1992). Este procedimento foi adotado nas três regiões distintas da represa - fluvial, transição e zona lacustre - que foram agrupados em quatro zonas: (I) RP: fluvial/braço Piracicaba, (II) RT: fluvial/braço Tietê, (III) Trans: transição, e (IV) Lake: lacustre.

Os questionários fechados (Anexo) visavam obter informações pessoais (nome, sexo, idade, escolaridade, estrutura domiciliar), informações sobre infra-estrutura e saneamento dos domicílios, aspectos relacionados à saúde dos pescadores e detalhamento da atividade pesqueira (Camargo, 1998; Mendonça, 1999; Walter, 2000; Ceregato, 2001, Petrere et al., 2006, Petrere et al., 2006). Os três primeiros tipos de informações mencionadas foram utilizadas para a descrição dos aspectos sociais dos pescadores. O detalhamento da pesca foi 
conduzido em duas vertentes: no âmbito da descrição e quantificação das capturas e o estudo da atividade sob o ponto de vista da economia, em que serão aplicados modelos econômicos. 


\section{CAPÍTULO 2}

\section{ASPECTOS SOCIAIS DAS PESCARIAS ARTESANAIS DA REPRESA DE BARRA BONITA}

\subsection{CONSIDERAÇÕES INICIAIS}

As comunidades ligadas às pescarias de pequena escala podem ser encontradas em todos os lugares ao redor do mundo. No Brasil, as pescarias artesanais de águas interiores são praticadas em áreas represadas e em rios (Petrere, 1989; Petrere, 1996). Embora a classificação dos pescadores seja tema de acalorado e interminável debate, Castro et al (2006) classificaram as pescarias em três categorias:

(1) Pesca artesanal profissional: praticada por pescadores que tem na atividade a principal fonte de renda. Apesar disso, a produção - de peixes, e consequentemente mercantil - é pequena, o excesso da produção é utilizada para consumo e o excedente da produção, revertido no incremento dos petrechos de pesca;

(2) Pesca de subsistência: os pescadores atuam com o objetivo de suprir a si mesmo e sua família. A produtividade é baixa e, quando há excedente, este pode ser comercializado;

(3) Pesca amadora/ esportiva: o pescado pode ser obtido para consumo e é praticada com a finalidade de lazer, turismo ou desporto, sem comercialização ou industrialização do pescado. 
A aplicação de questionários sócio-econômicos, baseados na estrutura familiar e na infra-estrutura do domicílio, pode ajudar a identificar as condições de vida e de trabalho dos pescadores e o perfil tecnológico da atividade (Mendonça, 1999). Conhecer a realidade sócio-econômica dos pescadores é de grande importância, tanto para a implementação de medidas de manejo de estoque pesqueiro quanto para o desenvolvimento econômico destas populações, embora nem sempre se dê importância a estes levantamentos (Walter, 2000).

No Brasil os estudos sobre as condições sócio-econômicas dos pescadores são voltados para pescadores artesanais (Okada et al., 1997; Mendonça, 1999; Camargo, 1998; Minte-Vera, 1997; Walter, 2000; Ceregato \& Petrere, 2003, Maruyama, 2007). conhecimento sobre as pescarias artesanais é ainda objeto de estudos sobre ecologia humana (Begossi \& Garavelo, 1990; Begossi \& Braga, 1992; Madi, 1998; Costa-Neto et al., 2002; Carvalho, 2002a, 2002b; Venturato, 2008).

\subsection{OBJETIVOS}

Caracterizar os aspectos sociais dos pescadores artesanais da represa de Barra Bonita, no que se refere à estrutura familiar e domiciliar e à atividade pesqueira.

\subsection{METODOLOGIA}

\subsubsection{Análise dos dados}

As variáveis sócio-econômicas, como dados pessoais, estrutura domiciliar, saneamento básico, saúde, nutrição e assistência previdenciária foram descritas de acordo com Walter (2000), Ceregato (2001) e Pereira (2005).

\subsection{RESULTADOS}

\subsubsection{Dados pessoais}

Os pescadores artesanais de Barra Bonita foram entrevistados nas estações seca (entre setembro e outubro de 2007) e chuvosa (entre março e abril de 2008) 
nos principais locais de desembarque da região do entorno da represa. Foram aplicados 123 questionários a 103 pescadores, ou seja, 20 pescadores foram ouvidos em ambos períodos.

A cada entrevista, o pescador foi questionado sobre a estimativa do número de pescadores atuantes naquele local de desembarque. A partir destas indicações, chegou-se à média de 128 pescadores na estação seca, zona fluvial/braço Tietê, apesar de ter sido apontada a presença de até 400 pescadores ativos nesta região. A menor estimativa foi obtida na estação seca, zona de transição (Média=11; Max=50 pescadores) (Tabela 3 ).

Tabela 3: Número entrevistas, de acordo com os locais visitados e zonas da represa de Barra Bonita.

\begin{tabular}{l|llll|llll}
\hline \multirow{2}{*}{ Pescadores } & \multicolumn{3}{l}{ Estação chuvosa } & & & \multicolumn{4}{l}{ Estação seca } & \\
\cline { 2 - 9 } & Zona & & & & Zona & & \\
\cline { 2 - 9 } & RP & RT & Trans & Lake & RP & RT & Trans & Lake \\
\hline Node entrevistados & 26 & 26 & 6 & 14 & 27 & 5 & 8 & 11 \\
Estimados (média) & 35 & 105 & 32 & 14 & 58 & 128 & 11 & 19 \\
Min & 8 & 20 & 20 & 2 & 3 & 10 & 8 & 4 \\
Max & 400 & 200 & 30 & 16 & 100 & 400 & 50 & 30 \\
SD & 29.042 & 91.398 & 11.690 & 7.887 & 110.209 & 81.803 & 7.010 & 3.273 \\
CV & 0.828 & 0.872 & 0.369 & 0.553 & 1.904 & 0.642 & 0.369 & 0.309 \\
\hline
\end{tabular}

As indicações dos pescadores possibilitaram estimar a intensidade de pesca na represa de Barra Bonita, isto é, a relação entre o número aproximado de pescadores atuantes pela área da represa. Assim a intensidade de pesca foi estimada em 1,30 indivíduos $/ \mathrm{km}^{2}$.

As pescarias artesanais foram praticadas principalmente por homens $(n=84)$, enquanto as mulheres responderam a 19 entrevistas (Tabela 4). Independente do gênero, as pescarias foram praticadas por pessoas casadas $(n=68)$, solteiras $(n=22)$, separadas $(n=9)$ e viúvas $(n=4)$ (Tabela 5).

Tabela 4. Frequiência absoluta do gênero dos pescadores artesanais da represa de Barra Bonita $\left(n_{\text {total }}=103\right)$.

\begin{tabular}{|c|c|c|c|c|c|c|c|c|c|}
\hline \multirow{3}{*}{ Sexo } & \multicolumn{4}{|c|}{ Estação seca } & \multicolumn{4}{|c|}{ Estação chuvosa } & \multirow{3}{*}{ Tota } \\
\hline & \multicolumn{4}{|c|}{ Zona } & \multicolumn{4}{|c|}{ Zona } & \\
\hline & RP & RT & TRANS & LAKE & RP & RT & TRANS & LAKE & \\
\hline Homem & 18 & 4 & 7 & 11 & 20 & 17 & 5 & 6 & 84 \\
\hline Mulher & 7 & 3 & 1 & - & 2 & 4 & 1 & 1 & 19 \\
\hline Total & 25 & 7 & 8 & 11 & 18 & 21 & 6 & 7 & 103 \\
\hline
\end{tabular}


Tabela 5. Frequiência absoluta do estado civil dos pescadores artesanais da represa de Barra Bonita.

\begin{tabular}{|c|c|c|c|c|c|c|c|c|c|}
\hline \multirow{3}{*}{ Estado civil } & \multicolumn{4}{|c|}{ Estação seca } & \multicolumn{4}{|c|}{ Estação chuvosa } & \multirow{3}{*}{ Total } \\
\hline & \multicolumn{4}{|c|}{\begin{tabular}{|l|} 
Zona \\
\end{tabular}} & \multicolumn{4}{|c|}{ Zona } & \\
\hline & RP & RT & TRANS & LAKE & RP & RT & TRANS & LAKE & \\
\hline Casado(a) & 20 & 3 & 6 & 3 & 14 & 13 & 3 & 6 & 68 \\
\hline Separado(a) & 2 & 2 & - & 1 & 1 & 3 & - & - & 9 \\
\hline Solteiro(a) & 2 & 2 & 2 & 6 & 2 & 4 & 3 & 1 & 22 \\
\hline Viúvo(a) & 1 & - & - & 1 & 1 & 1 & - & - & 4 \\
\hline Total & 25 & 7 & 8 & 11 & 18 & 21 & 6 & 7 & 103 \\
\hline
\end{tabular}

A maior parte dos pescadores $(n=21)$ tinha entre 30 e 39 anos, com idade média de 41 anos, e as mulheres ( $n=7$ ), entre 40 e 49 anos, com idade média de 40 anos (Figura 2). Quando à escolaridade, a maior parcela dos homens possuía ensino básico incompleto ( $n=32$ ) e as mulheres, ensino básico completo ( $n=10)$ (Figura 3).

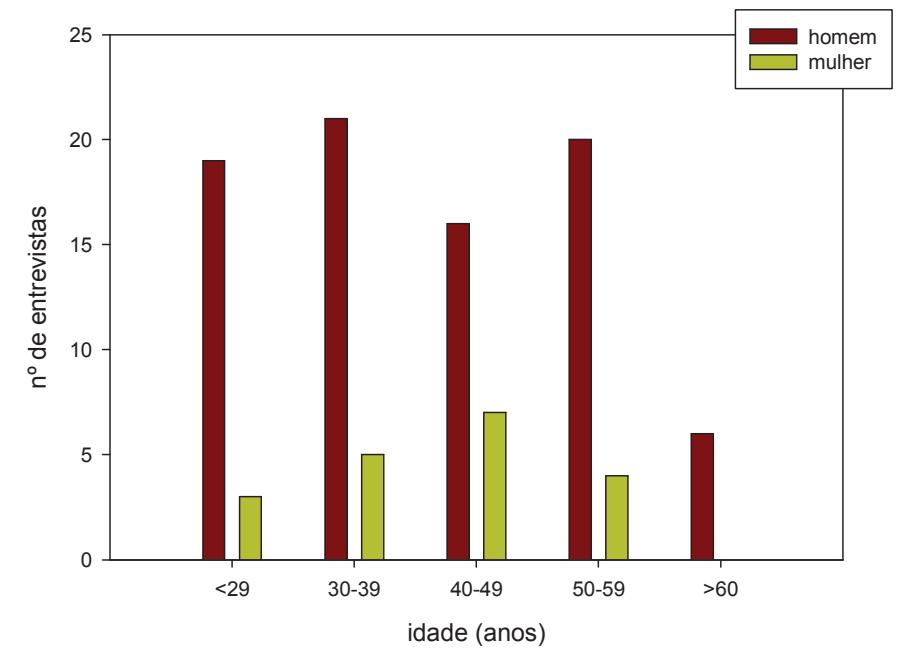

Figura 2: Distribuição de faixa etária por gênero para os pescadores artesanais da represa de Barra Bonita.

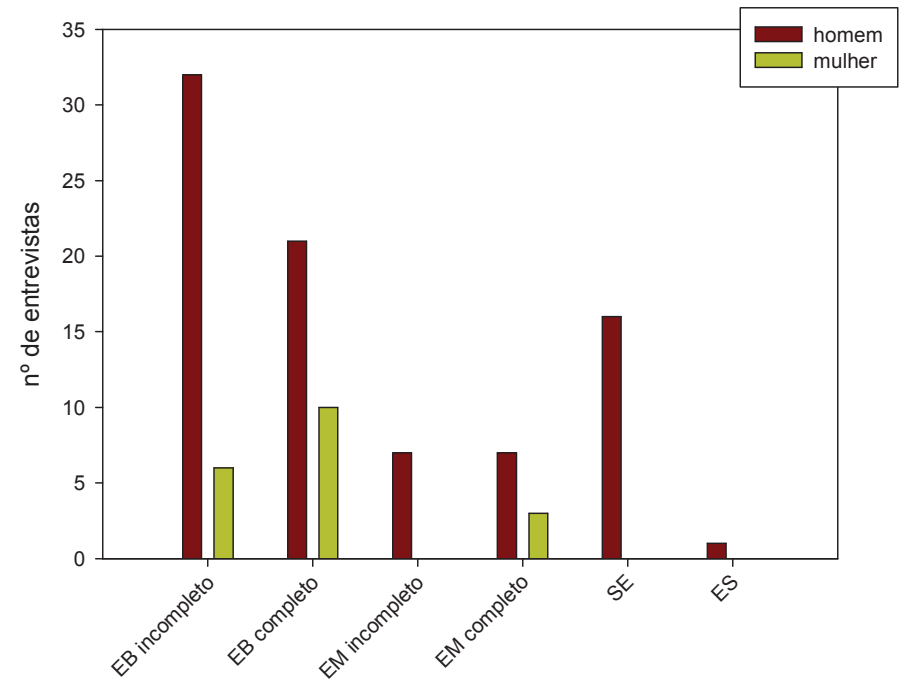

Figura 3: Distribuição de escolaridade por gênero para os pescadores artesanais da represa de Barra Bonita, onde (1) $\mathrm{EB}_{\text {incompleto }}=$ ensino básico incompleto; (2) $\mathrm{EB}_{\text {completo }}=$ ensino básico completo; (3) $\mathrm{EM}_{\text {incompleto }}=$ ensino médio incompleto; (4) $\mathrm{EM}_{\text {completo }}$ ensino médio completo; (5) SE= sem estudo; (6) $\mathrm{ES}$ = ensino superior completo. 
Quando indagados sobre o número de dependentes que trabalhavam, a maior parte dos pescadores indicou haver, além de sua fonte de renda, contribuições mensais médias de mais dois dependentes $(n=12, R \$ 710,83)$, seguidos dos que contavam com a renda de três dependentes $(n=9, R \$ 917,78)$. Dentre os pescadores que contavam apenas com sua renda para sustento da família, 22 afirmaram ter dois dependentes sem trabalho, seguidos dos que tinham um ( $n=17)$ e três $(n=10)$ dependentes nesta situação (Figura 4).

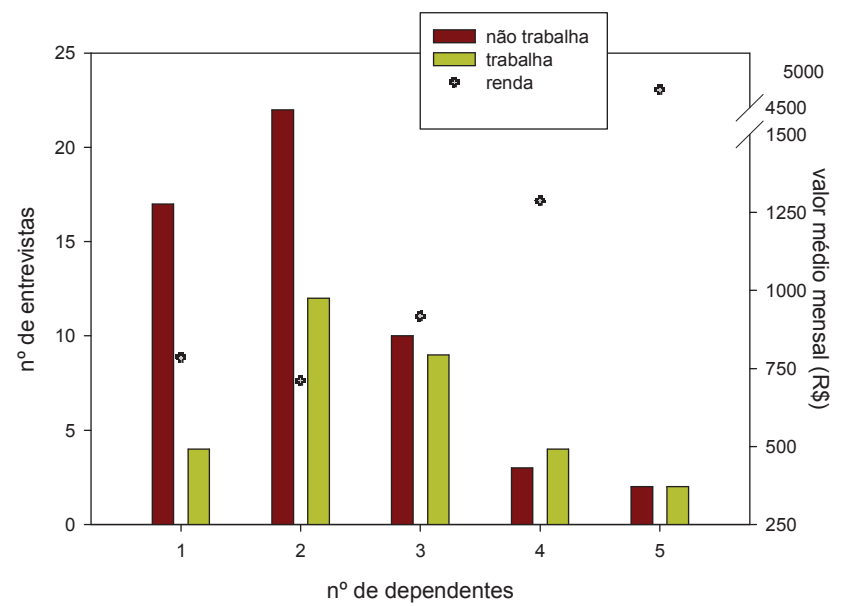

Figura 4: Frequiência absoluta de dependentes dos pescadores que trabalham, com respectiva renda mensal média e dos que não trabalham.

\subsubsection{Estrutura domiciliar}

Os pescadores entrevistados eram provenientes, principalmente, de outros municípios do Estado de São Paulo ( $n=59$ ), seguidos dos pescadores oriundos da Bahia $(n=20)$. Dos pescadores paulistas, a maioria era do município de Santa Maria da Serra $(n=9)$, seguidos dos pescadores de Piracicaba e São Paulo ( $n=6$, cada) (Figura 5). A maior parte dos pescadores residia nos locais das entrevistas entre 1 e 10 anos $(n=78)$, seguidos daqueles que residiam entre 11 a 20 anos ( $n=12$ ) (Figura 6). 


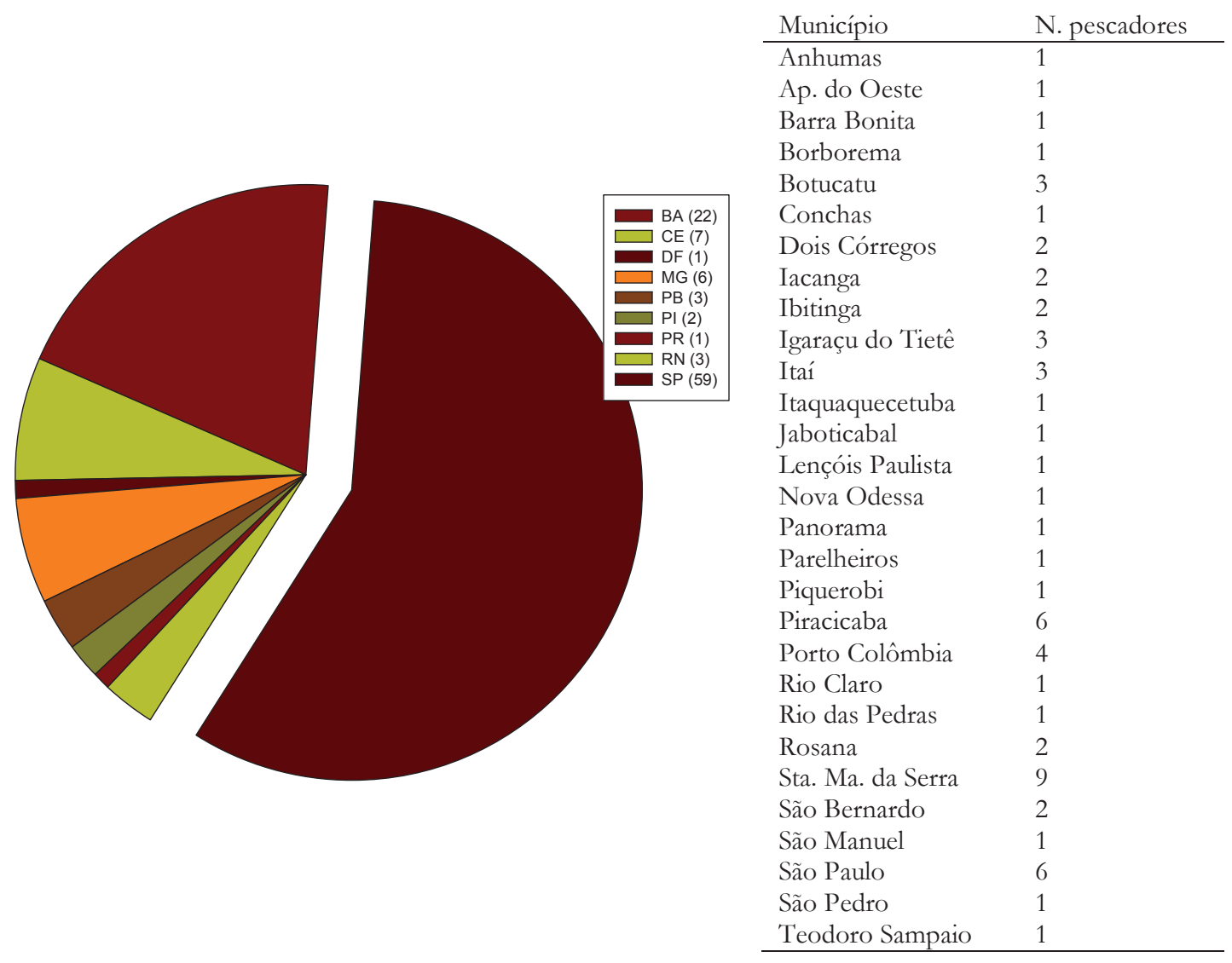

Figura 5: Origem dos pescadores artesanais da represa de Barra Bonita $(n=102)$, com destaque para os pescadores oriundos do Estado de São Paulo $\left(n_{\text {total }}=59\right)$

Os pescadores apontaram como aspectos favoráveis da região a qualidade do ar ( $n=$ 102), o clima ( $n=99$ ) e a qualidade da água para a pesca $(n=97)$, principalmente. Os aspectos desfavoráveis foram proximidade/distância de escolas e centros comerciais $(n=70)$, transporte $(n=67)$ e qualidade da água para consumo ( $n=67)$ (Figura 7).

A maior parte dos pescadores vivia em casa própria $(n=78)$, seguidos dos que viviam em casa alugada ( $n=18$ ) (Figura 8). A descrição da qualidade das paredes, telhado e piso das construções encontram-se na Tabela 6. As paredes eram principalmente de alvenaria $(n=51)$ e foi registrado também o uso de um tipo de material para as paredes, como por exemplo, lona e bambu ( $n=13)$. O principal material utilizado para a construção dos telhados foi a telha de barro $(n=40)$. Para os pisos, houve maior indicação do uso de cimento para a maior parte das casas ( $n=33$ ), embora tenham sido registradas casas onde não há revestimento para o piso, apenas terra batida $(n=24)$. 


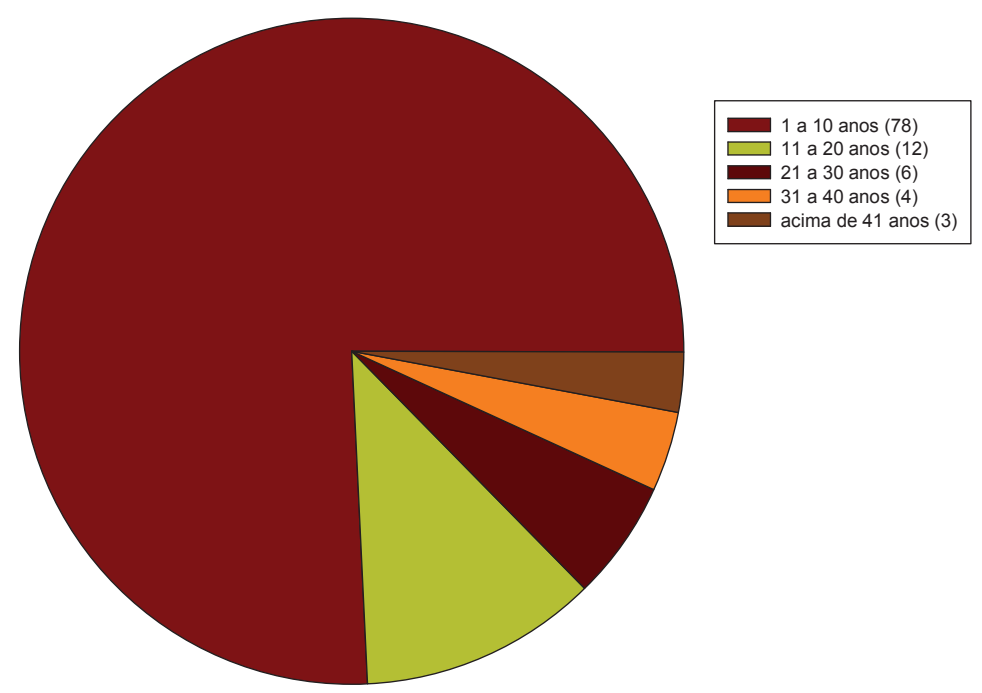

Figura 6: Tempo de residência dos pescadores (anos) no entorno da represa de Barra Bonita.

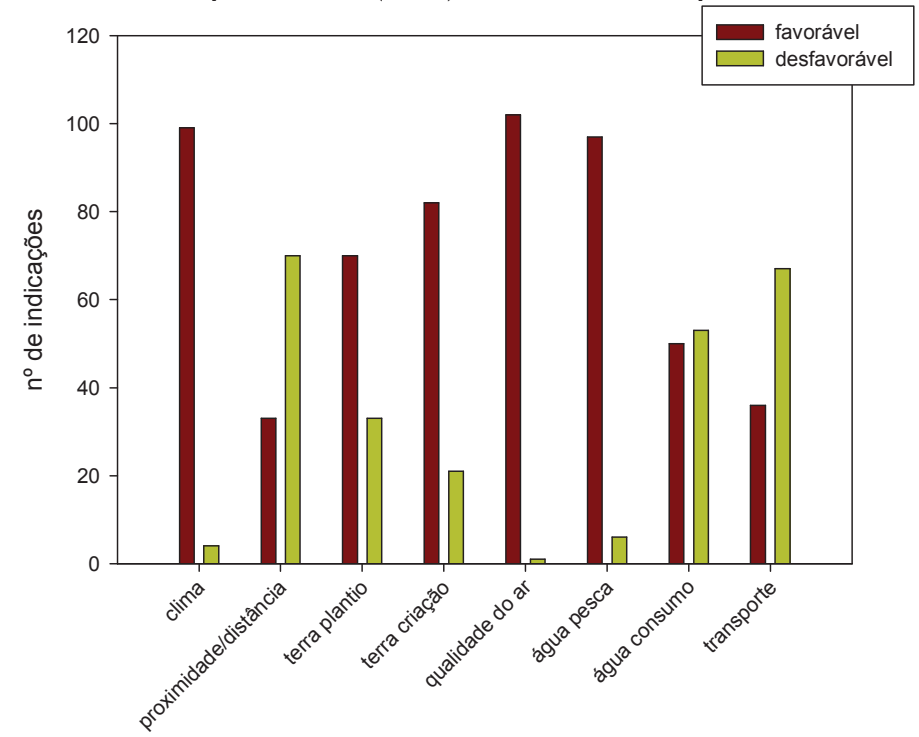

Figura 7: Aspectos favoráveis e desfavoráveis apontados pelos pescadores artesanais de Barra Bonita

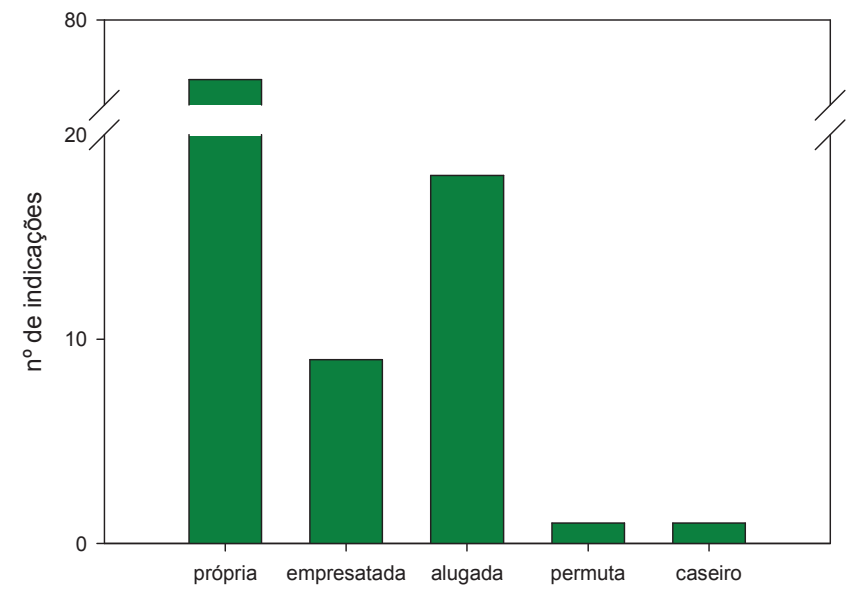

Figura 8: Situação de moradia dos pescadores artesanais de Barra Bonita 
Tabela 6: Tipo de material utilizado para a construção das residências dos pescadores artesanais da represa de Barra Bonita $(n=102)$

\begin{tabular}{|c|c|c|c|c|c|}
\hline & \multicolumn{2}{|l|}{ Telhado (n) } & \multicolumn{2}{|l|}{ Piso $(\mathrm{n})$} \\
\hline Alvenaria & 51 & Laje & 1 & Cerâmica & 17 \\
\hline Lona & 4 & Telha de barro & 40 & Ladrilho & 20 \\
\hline Madeira & 3 & Fibrocimento & 21 & Terra batida & 24 \\
\hline Lixa * & 1 & Lona & 29 & Cimento & 33 \\
\hline Alvenaria + lixa & 1 & Lixa & 7 & Madeira & 2 \\
\hline Alvenaria + madeira & 1 & Plástico & 5 & Ladrilho + cimento & 1 \\
\hline Lona + bambu & 3 & Telha de barro + zinco & 1 & Terra batida + cimento & 3 \\
\hline Lona + madeira & 13 & Telha de barro + fibrocimento & 3 & Terra batida + lixa & 1 \\
\hline Lona+ lixa & 5 & Lona + lixa & 4 & Lixa + lona & 1 \\
\hline Lona + madeira + lixa & 2 & Lixa + plástico & 1 & & \\
\hline Madeira + lixa & 11 & & & & \\
\hline Madeira + plástico & 5 & & & & \\
\hline Madeira + lixa + plástico & 1 & & & & \\
\hline Lixa + adobe & 1 & & & & \\
\hline
\end{tabular}

A maioria das residências tinha fornecimento de energia elétrica $(n=64)$, seguidas daquelas que utilizavam lampião e/ou vela como fonte de energia luminosa $(n=34)$. Utilizam preferencialmente gás de cozinha $(n=100)$ para cozinhar (Tabela 7$)$.

Tabela 7: Fonte de energia e combustível de cocção

\begin{tabular}{ll|ll}
\hline Fonte de energia & & Combustível de cocção & \\
\hline Rede & 64 & Gás & 100 \\
Lampião/vela & 34 & Lenha & 8 \\
Particular & 1 & Gás + lenha & 6 \\
Gerador & 4 & & \\
\hline
\end{tabular}

A terra do entorno das moradias dos pescadores era cultivada por $34,0 \%$ deles, enquanto 53,4\% criavam um ou mais tipos de animais de estimação ou para abate (Tabela 8). Os principais animais indicados foram o cão $(n=35)$ e a galinha $(n=27)$ (Figura 9).

Tabela 8: Frequiência relativa do uso da terra do entorno da represa de Barra Bonita para plantio e para criação de animais.

\begin{tabular}{ll|ll}
\hline Cultivo de terra (\%) & Criação de animais (\%) & \\
\hline Não & 66,0 & Não & 46,6 \\
Sim & 34,0 & Sim & 53,4 \\
\hline
\end{tabular}

A avaliação do conforto das residências, através da quantificação dos bens de consumo, indicou que em 80 residências havia televisão, 76 possuíam aparelhos de rádio e 67, geladeira, entre os itens mais vezes indicados (Figura 10). 


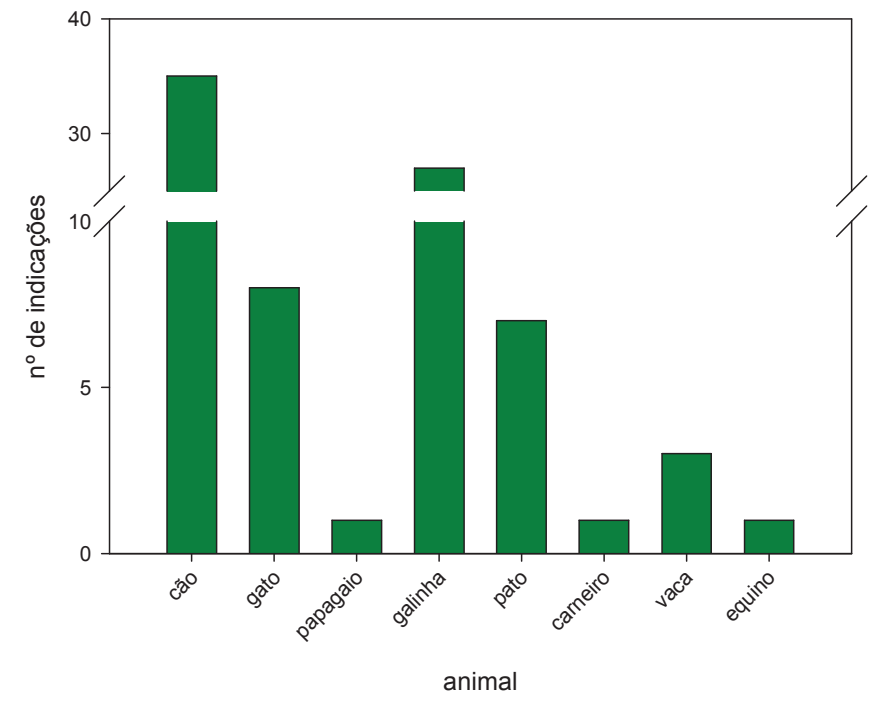

Figura 9: Frequiência absoluta dos animais criados pelos pescadores artesanais de Barra Bonita

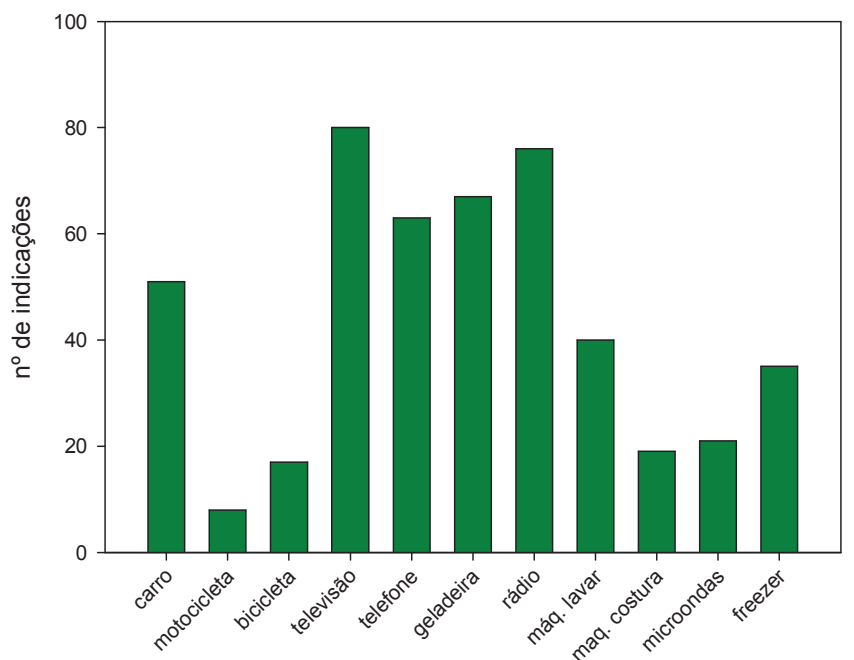

Figura 10: Posse de bens de consumo indicados pelos pescadores de Barra Bonita

\subsubsection{Saneamento}

As entrevistas indicaram que a maior parte dos domicílios possuía abastecimento de água ( $n=39$ ) ou utilizavam água de nascentes $(n=31)$; apesar disso, sete pescadores que tinham residência em outras cidades da região afirmaram transportar o suprimento de água quando iam para a represa. A água consumida pela maior parte dos pescadores não recebia nenhum tipo de tratamento $(n=64)$ ou era filtrada $(n=24)$ (Figura 11). 


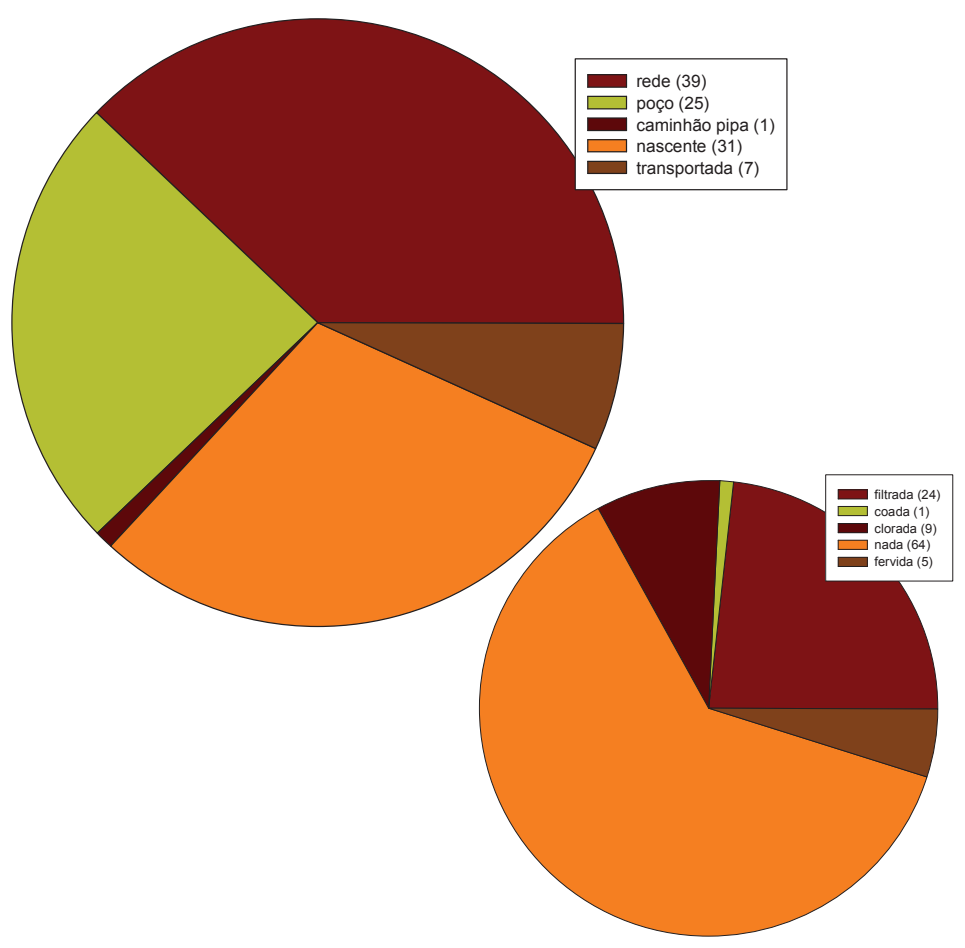

Figura 11: Abastecimento e tratamento da água consumida pelos dos pescadores de Barra Bonita.

As instalações sanitárias de seus domicílios eram, para a maioria, construídas dentro de casa $(n=70)$ e o esgoto doméstico tinha como principal destino as fossas rudimentares construídas à beira da represa ( $n=46)$ (Figura 12).

Os resíduos sólidos gerados eram coletados por caminhões $(n=54)$ ou queimados ( $n=$ 47), principalmente e podiam ter mais de um destino, ou seja, faziam uso de mais de um modo de deposição do lixo gerado (Figura 13). 


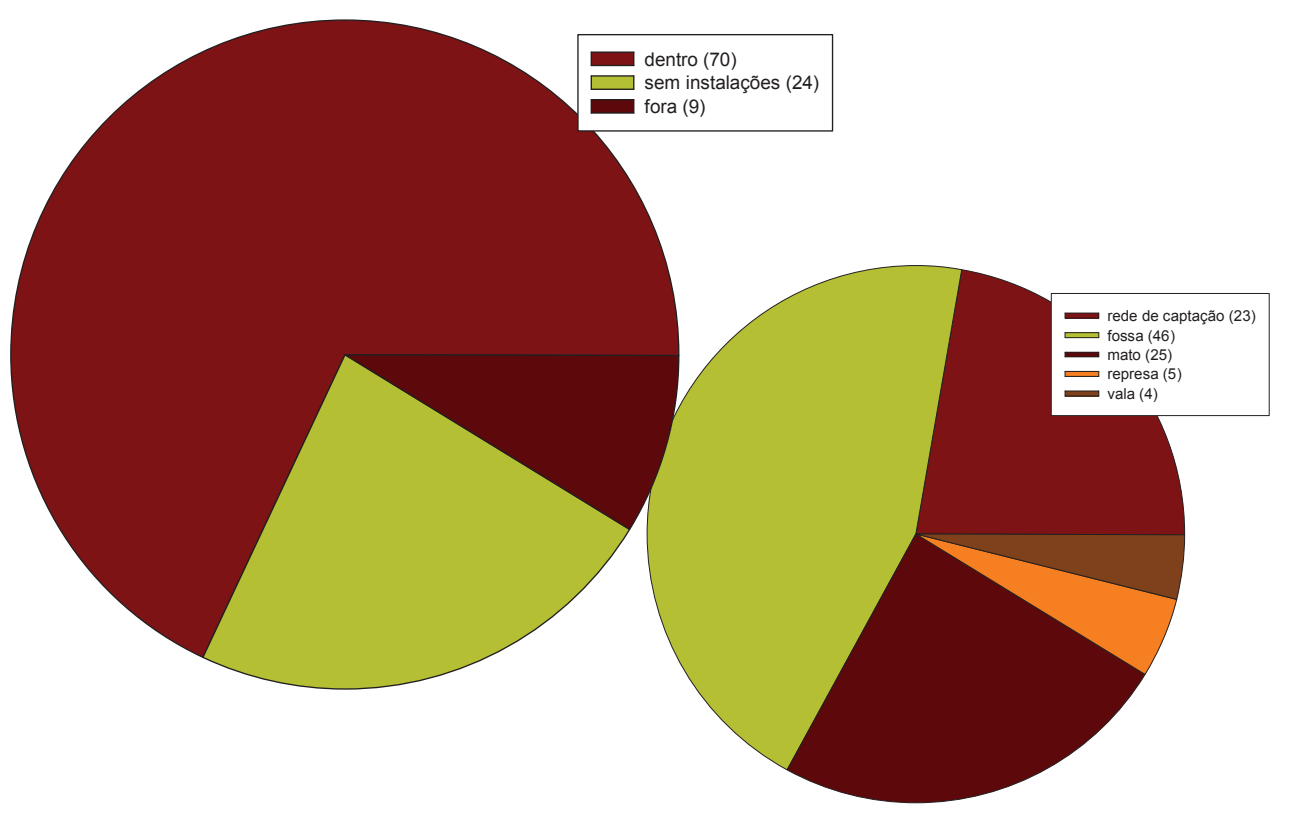

Figura 12: Localização das instalações sanitárias e deposição do esgoto dos domicílios dos pescadores da represa de Barra Bonita

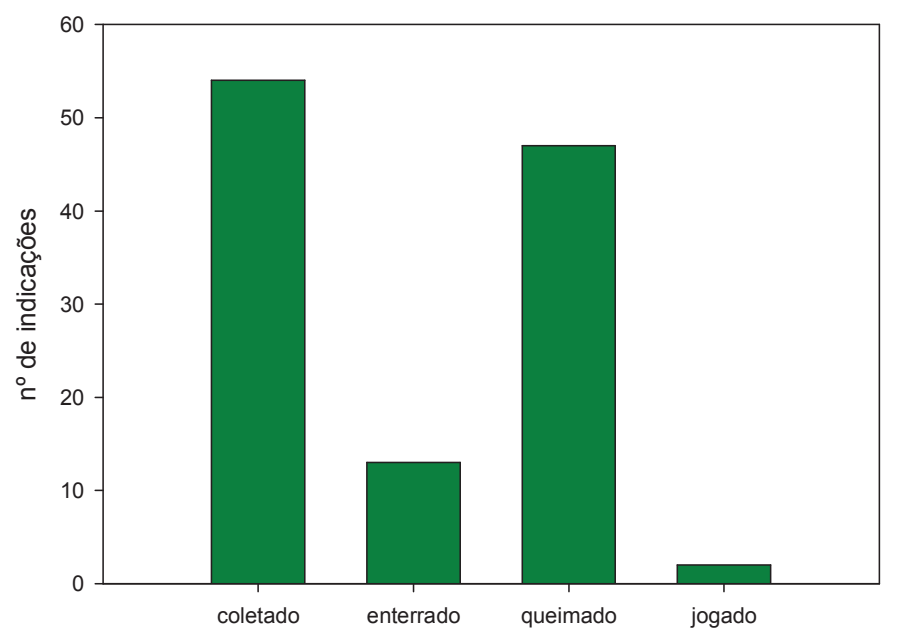

Figura 13: Deposição de resíduo sólido gerado pelos pescadores da represa de Barra Bonita.

\subsubsection{Saúde}

As águas da represa de Barra Bonita eram utilizadas principalmente para lazer $(n=49)$ e higiene ( $n=48)$ (Figura 14).

Para atendimento à saúde, os pescadores mencionaram serviços de postos de saúde ( $n=101$ ) e hospitais públicos ( $n=98$ ); apenas sete deles mencionaram o atendimento médico 
particular (Figura 15). A assistência previdenciária pública foi paga pela maioria deles $(n=96)$ e apenas dois afirmaram pagar previdência privada (Figura 16).

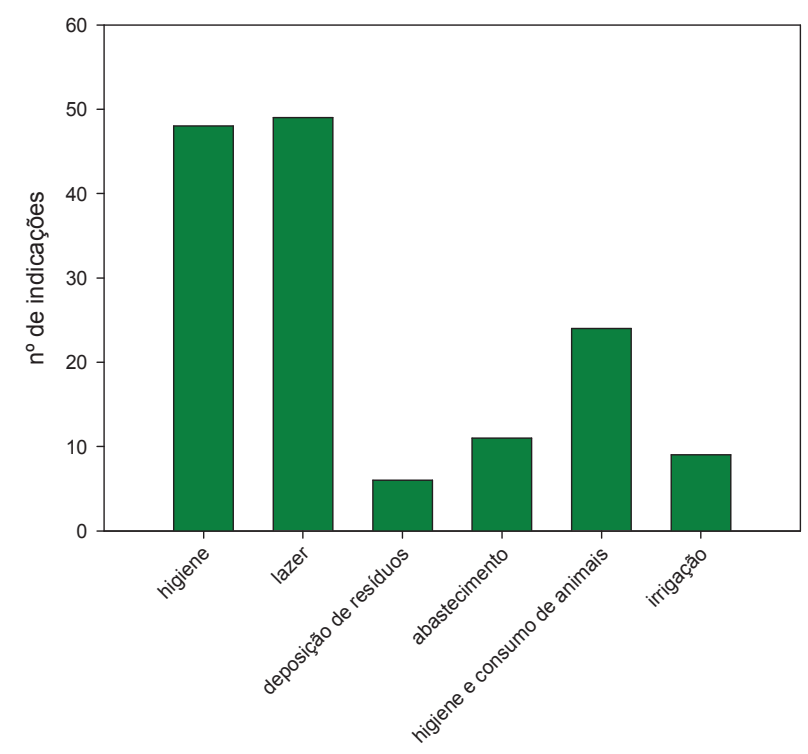

Figura 14: Utilização das águas da represa de Barra Bonita pelos pescadores artesanais

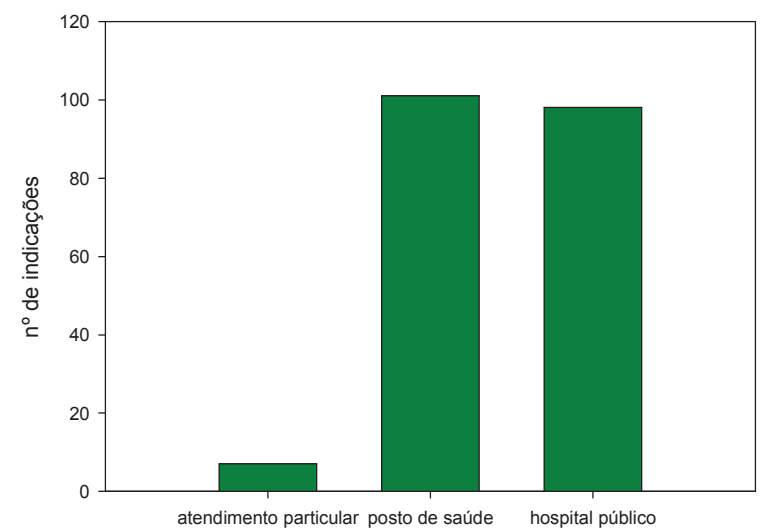

Figura 15: Atendimento à saúde dos pescadores da represa de Barra Bonita

As principais doenças por eles contraídas ou diagnosticadas nos seis meses anteriores a esta pesquisa foram gripe $(n=62)$, micose $(n=43)$ e problemas dentários ( $n=23)$ (Figura 17). Mencionaram a incidência de insetos e outros animais no entorno das moradias, principalmente mosca comum (Drosophila sp) ( $n=102)$, pernilongos (Culex $s p)(n=101)$ e moscas varejeiras (Dermatobia $\mathrm{sp}$ ) ( $n=99)$. A maioria $(n=82)$ nunca foi atacada por animais peçonhentos e os poucos ataques foram devidos a escorpião $(n=8)$, cobra e aranha $(n=5$, cada) (Figura 18). 


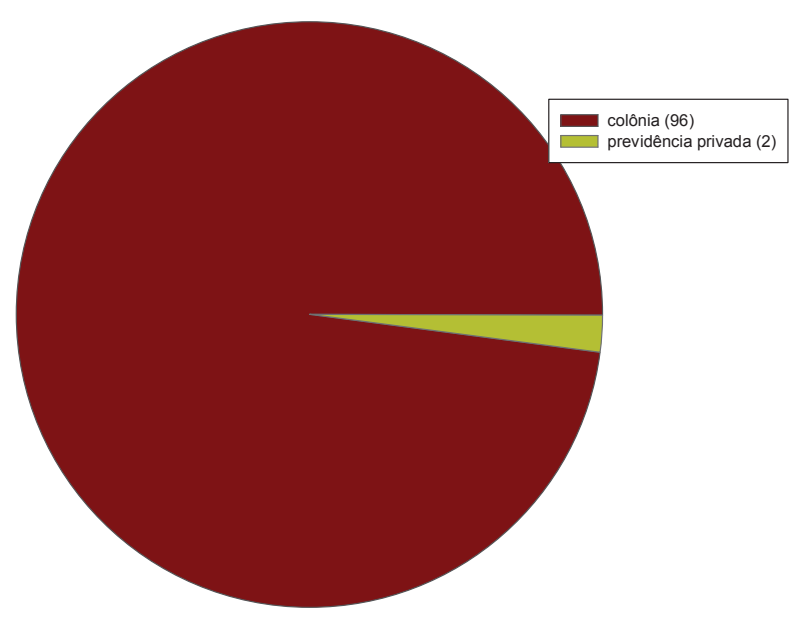

Figura 16: Assistência previdenciária dos pescadores da represa de Barra Bonita.

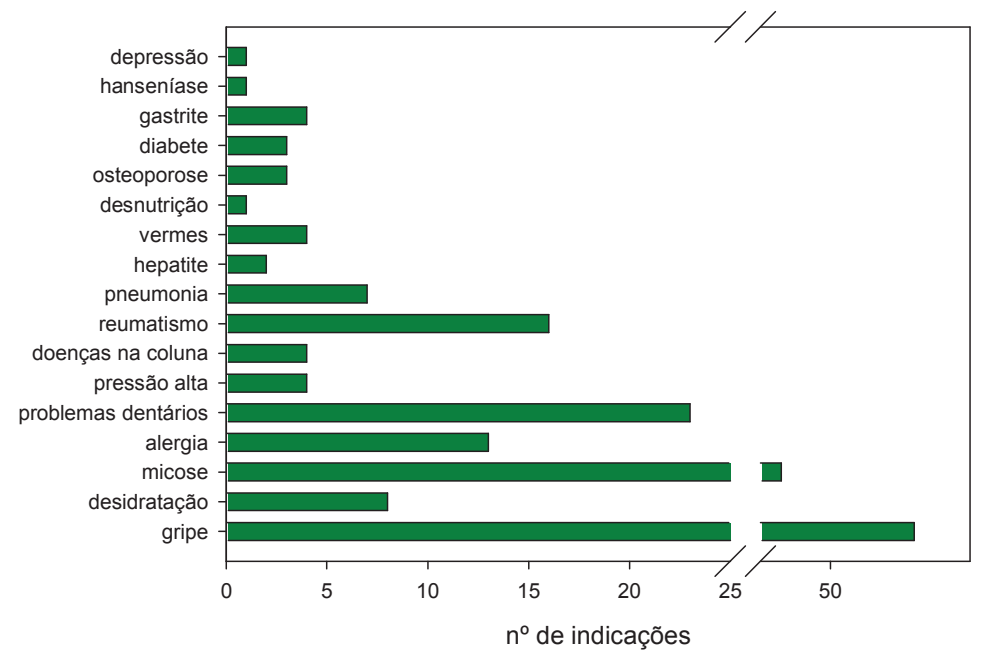

Figura 17: Doenças contraídas pelos pescadores de Barra Bonita ou diagnosticadas.
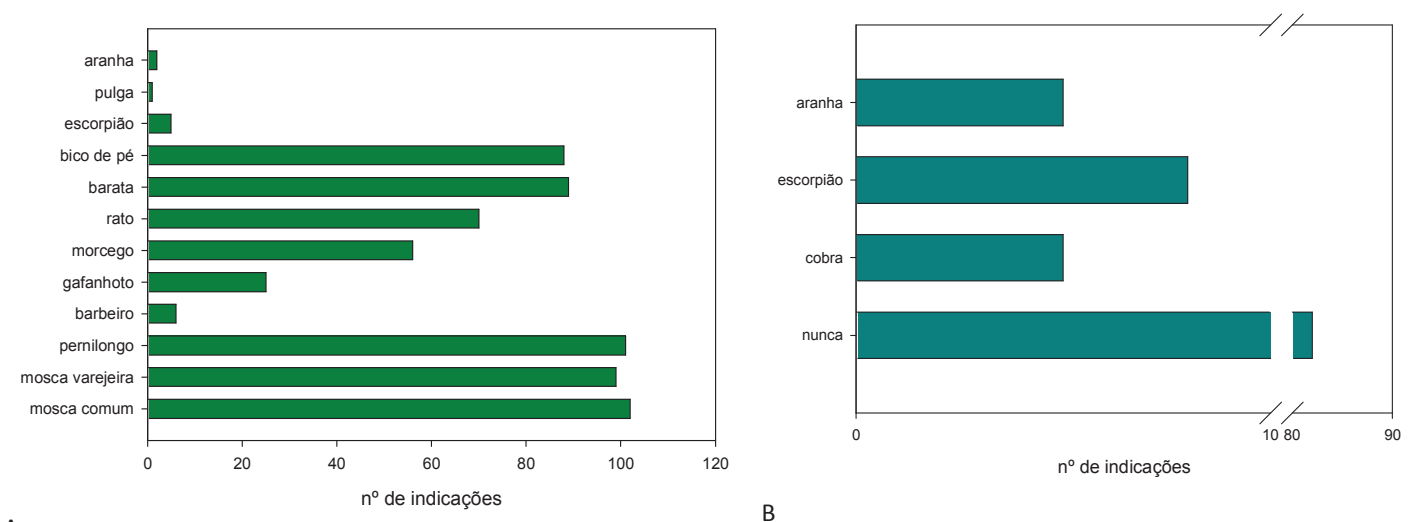

Figura 18: (A) Incidência de insetos e outros animais no entorno das moradias dos pescadores e (B) Ataque de animais peçonhentos aos pescadores da represa de Barra Bonita. 
A ocorrência de animais silvestres foi registrada, tendo sido mencionados, principalmente, capivaras (Hydrochoerus hydrochaeris) $(n=80)$, aves $(n=48)$ e tatus (família Dasypodidae) ( $n=38)$ (Figura 19A). Foram apontados apenas dois ataques por animais silvestres, realizados por cachorro do mato (Speothos venaticus) $(n=1)$ e de gato do mato (Leopardus sp) ( $\mathrm{n}=1$ ) (Figura 19B). Os usos de animais silvestres foram apontados por 21 pescadores, que mencionaram o consumo de capivara $(n=11)$, tatu $(n=5)$, ratão do banhado (Myocastor coypus) ( $n=2)$, jacaré (Caiman sp) $(n=2)$ e lagarto (Ordem Squamata) $(n=1)$ (Figura 19C).

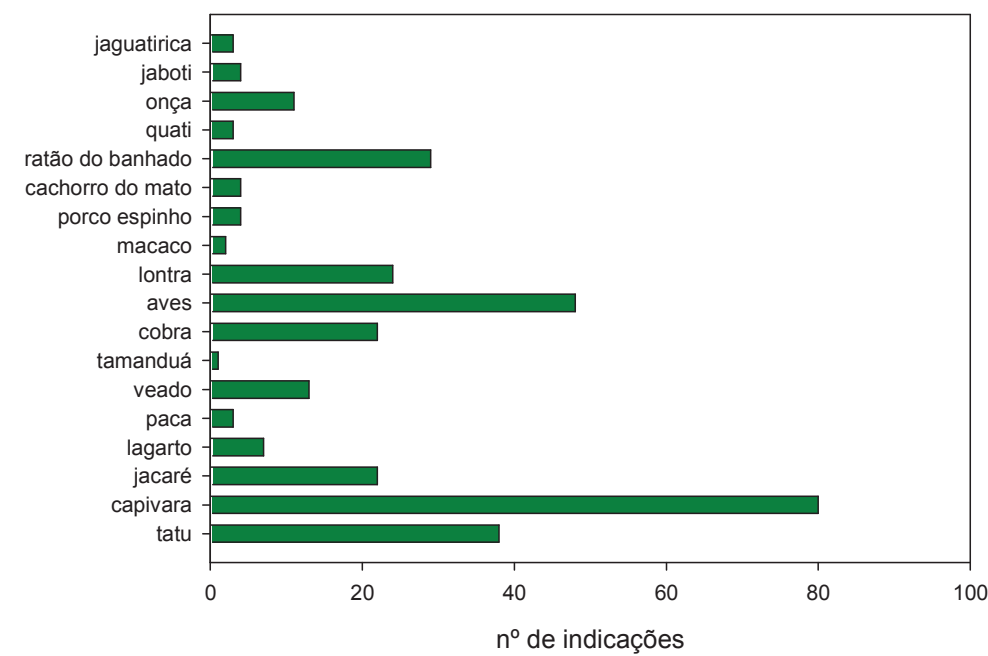

A
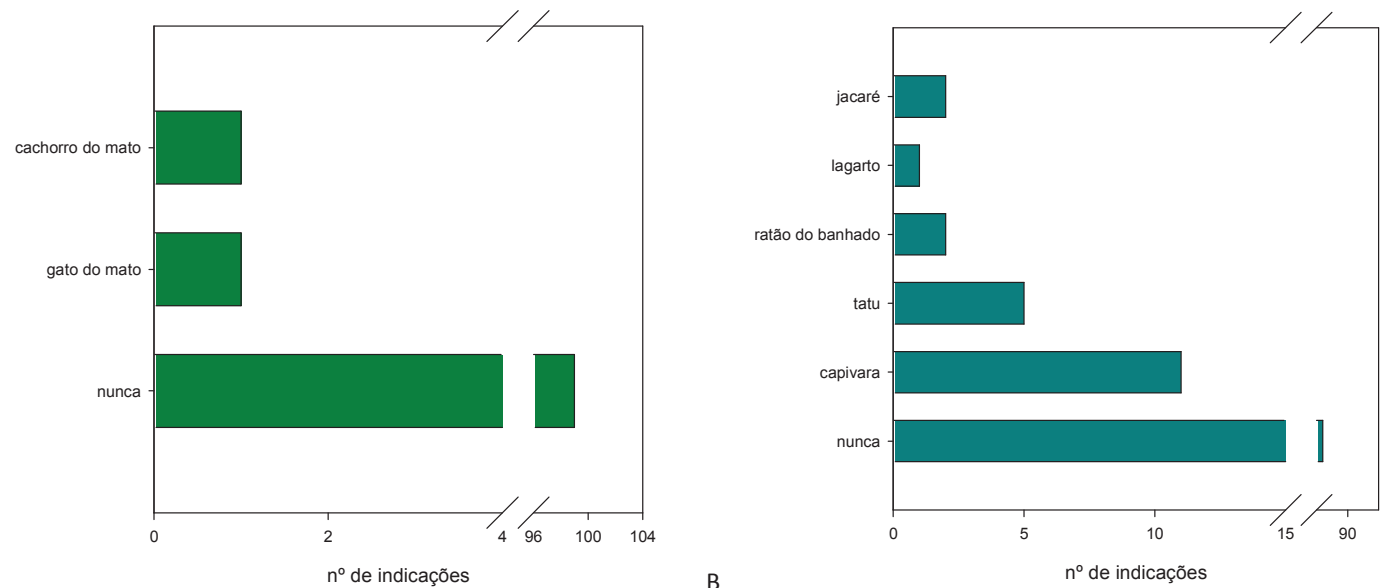

Figura 19: (A) Indicação da presença de animais silvestres, (B) Ataque de animais silvestres aos pescadores e (C) Indicação do uso de animais silvestres pelos pescadores do entorno da represa de Barra Bonita. 
A vegetação do entorno da represa era explorada para fins medicinais $(n=77)$, alimentação ( $n=29)$, ornamentação $(n=14)$, alimentação de animais $(n=2)$, fins combustíveis $(n=2)$ e como material de construção ( $n=2)$ (Figura 20).

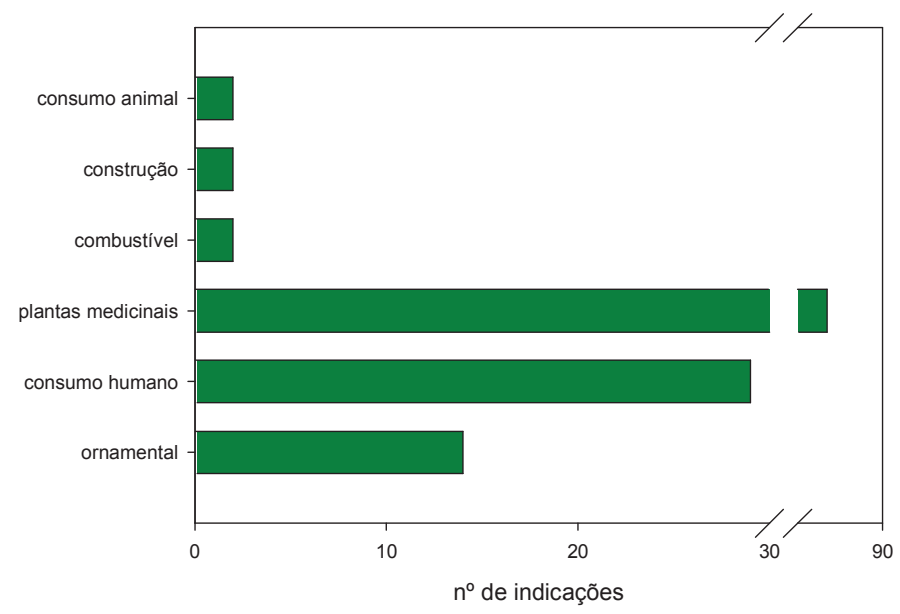

Figura 20: Indicação do uso de plantas da região pelos pescadores da represa de Barra Bonita.

A dieta alimentar consistia no consumo de carne vermelha e de frango ( $n=103$, cada), arroz $(n=103)$, peixe fresco da própria captura $(n=102)$, verduras $(n=101)$, farináceos $(n=95)$, laticínios e frutas ( $n=98$, cada) e leguminosas ( $n=84$ ) (Figura 21). Os peixes capturados pelos pescadores eram consumidos duas $(n=27)$ ou três $(n=26)$ vezes por semana, principalmente (Figura 22).

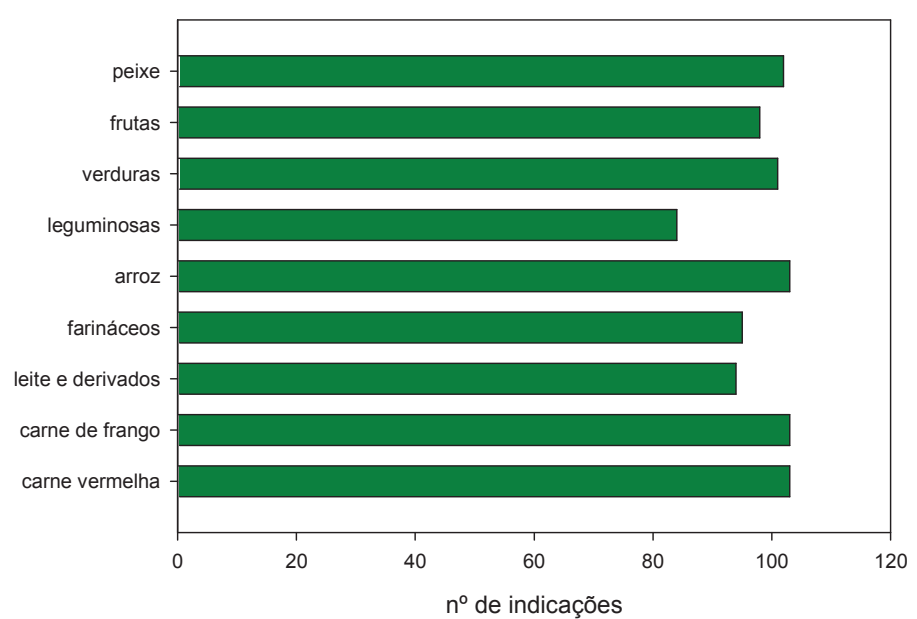

Figura 21: Indicação da dieta alimentar dos pescadores da represa de Barra Bonita. 


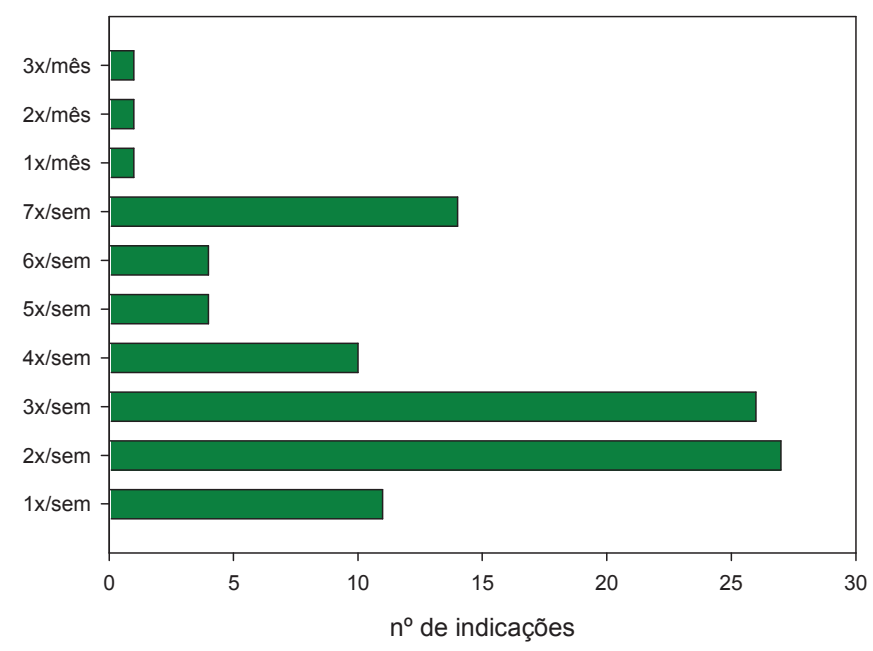

Figura 22: Indicação da frequiência do consumo de peixe capturado pelos pescadores da represa de Barra Bonita.

Os supermercados da região eram os principais locais de abastecimento de produtos hortifrutigranjeiros $(n=87)$ e de origem protéica $(n=91)$. A produção de subsistência foi indicada como fonte de hortifrutigranjeiros $(n=15)$ e de proteína $(n=3)$. Além destas fontes, os pescadores mencionaram a comercialização de hortifutis $(n=12)$ e produtos protéicos $(n=5)$ em caminhões que percorriam a região com esta finalidade e a aquisição dos alimentos através de patrões ${ }^{1}$ e peixeiros ${ }^{2}$ (Figura 23).

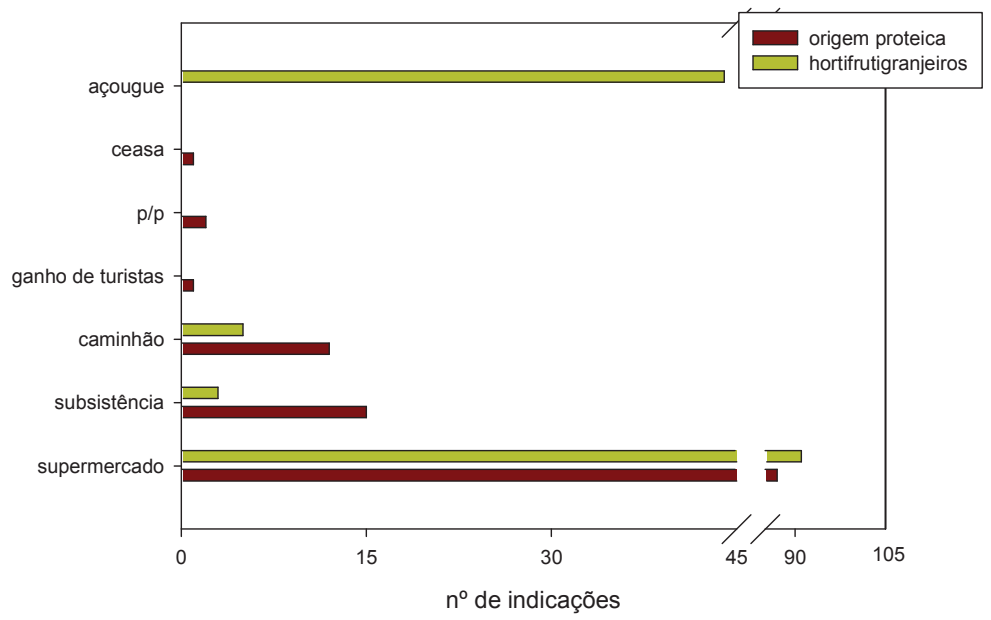

Figura 23: Indicação da origem dos produtos hortifrutigrangeiros e de origem protéica consumidos pelos pescadores da represa de Barra Bonita. p/p é a aquisição de produtos de patrões e/ou peixeiros

\footnotetext{
${ }^{1}$ Os patrões são aqueles que financiam a aquisição do material de pesca necessário, dos alimentos e remédios para as famílias dos pescadores.

${ }^{2}$ Principal intermediário que atuava junto aos pescadores de Barra Bonita, comercializando o pescado com outros intermediários, peixarias, frigoríficos, restaurantes e no CEAGESP
} 


\subsection{DISCUSSÃO}

\subsubsection{Dados pessoais}

As pescarias artesanais em represas têm sido estudadas no âmbito social em busca de respostas para melhor compreender o modo de vida do pescador e a dinâmica entre este e o recurso explorado (Mendonça, 1999; Venturato, 2007). De acordo com a FAO (2009b) as pescarias artesanais têm importante contribuição na nutrição, segurança alimentar, meio de subsistência e redução da pobreza, principalmente nos países em desenvolvimento. Esta atividade dá empregos a milhões de pescadores, incluindo seus familiares, diretamente engajados nas atividades pesqueiras e a outros que trabalham na cadeia de produção, como processamento e comércio de pescado, desenvolvimento/construção de embarcações e equipamentos de pesca (FAO, 2009c)

Estima-se que a represa de Barra Bonita conte atualmente com uma população de pescadores à razão de 1,30 ind. $/ \mathrm{km}^{2}$, intensidade de pesca superior à registrada por Maruyama (2007),que foi de 1,18 pescador $/ \mathrm{km}^{2}$ em seus ambos períodos de estudo. Venturato (2008) analisou as características dos moradores da região do Tanquã e relatou a presença de 21 famílias de pescadores artesanais atuantes na região. Entre 1989 e 1991 foi registrada a presença de 0,23 ind. $/ \mathrm{km}^{2}$ (dados compilados por Petrere et al, 2002). A intensidade de pesca apresentada aqui pode ser considerada elevada, principalmente quando comparada aos valores obtidos por Ceregato (2001) e Minte-Vera (1997) para as represas situadas nos extremos oeste $\left(0,12\right.$ e 0,26 ind. $/ \mathrm{km}^{2}$ registradas nas estações seca e chuvosa) e leste $\left(0,90\right.$ ind. $\left./ \mathrm{km}^{2}\right)$ da represa de Barra Bonita, respectivamente. Petrere et al (2006) mencionaram o declínio das pescarias artesanais da Represa Billings $\left(0,76\right.$ ind./ $\left./ \mathrm{km}^{2}\right)$, cujos pescadores optavam por exercer suas pescarias na represa de Barra Bonita devido ao aumento da violência na Grande São Paulo, mas anos mais tarde a intensidade de pesca havia subido para 1,00 ind./ $\mathrm{km}^{2}$, conforme registros de Silva (2009). Quanto às pescarias do Complexo de Urubupungá, Agostinho et al. (2007) sugerem que o número de pescadores atuantes na represa de Jupiá tenha declinado nos últimos anos e que haja cerca de 30 pescadores atuantes na represa de Ilha Solteira. De fato, Maruyama (op. cit.) também constatou o declínio da intensidade pesqueira ao longo do Rio Tietê, no sentido Barra Bonita - Três Irmãos. No entorno da represa de Barra Bonita, embora haja comunidades/famílias tradicionais de pescadores, como o caso da comunidade Tanquã, muitos pescadores não mantem vínculos com o local em que se estabelecem e, à medida 
que os estoques pesqueiros declinam, os pescadores se mudam para outras represas (Petrere et al., 2006). Assim, as oscilações nos valores de intensidade de pesca podem ser justificadas pelas mudanças contínuas dos pescadores em busca de maiores produções pesqueiras (Tabela 9).

Tabela 9: Comparação entre a intensidade de pesca na represa de Barra Bonita, outras represas do Rio Tietê, represas do Brasil e de outras regiões tropicais

\begin{tabular}{|c|c|c|c|}
\hline & Represa & Autor & Intensidade de pesca (pescador $/ \mathrm{km}^{2}$ ) \\
\hline \multirow{15}{*}{$\begin{array}{l}\text { Rio } \\
\text { Tietê }\end{array}$} & \multirow{3}{*}{ Barra Bonita } & Petrere et al 2002 & 0,23 \\
\hline & & Maruyama (2007) - 2003/04 & 1,18 \\
\hline & & Presente estudo & 1,30 \\
\hline & \multirow{3}{*}{ Billings } & Minte-Vera (1997) & 0,90 \\
\hline & & Petrere et al (2006) & 0,76 \\
\hline & & Silva (2008) & 1,00 \\
\hline & \multirow{2}{*}{ Bariri } & Maruyama (2007) - 2001 & 0,71 \\
\hline & & Maruyama (2007) - 2003/04 & 0,39 \\
\hline & \multirow{2}{*}{ Ibitinga } & Petrere et al (2002) & 0,23 \\
\hline & & Maruyama (2007) - 2001 & 0,25 \\
\hline & \multirow{2}{*}{ Promissão } & Petrere et al (2002) & 0,15 \\
\hline & & Maruyama (2007) - 2001 & 0,32 \\
\hline & \multirow{3}{*}{$\begin{array}{l}\text { Nova } \\
\text { Avanhandava } \\
\text { Três Irmãos }\end{array}$} & Petrere et al (2002) & 0,18 \\
\hline & & Maruyama (2007) - 2001 & 0,22 \\
\hline & & Maruyama (2007) - 2001 & 0,21 \\
\hline \multirow{3}{*}{$\begin{array}{l}\text { Rio } \\
\text { Tietê e } \\
\text { Alto } \\
\text { Rio } \\
\text { Paraná }\end{array}$} & $\begin{array}{l}\text { Complexo de } \\
\text { Urubupungá } \\
\text { (Jupiá + Ilha } \\
\text { Solteira) }\end{array}$ & $\begin{array}{l}\text { Valor calculado a partir dos dados de Ceregato } \\
\text { (2001) }\end{array}$ & $\begin{array}{l}0,12 \text { - estação seca } \\
0,26 \text { - estação chuvosa }\end{array}$ \\
\hline & Jupíá & Petrere et al (2002) & 0,14 \\
\hline & Ilha Solteira & Dados compilados por Agostinho et al (2007) & Estimativa de 30 pescadores \\
\hline
\end{tabular}

A análise por gênero dos praticantes das pescarias artesanais, a exemplo de outras represas, também apontou o exercício predominante pelo sexo masculino (81,6\%), fato corroborado pelos registros da SEAP (2006), cujos estudos apontaram a participação de $30,53 \%$ de mulheres nas atividades pesqueiras estudadas. Para a represa Billings, os estudos de Minte-Vera (1997, 16,4\%) e de Petrere et al. (2007, 10,3\%) indicaram o declínio da presença feminina. Maruyama (2007) apontou a presença de 92,1\% de homens nas pescarias do Médio Tietê e 92,0\% no Baixo Tietê. Estes resultados refletem a maior participação feminina diretamente na pesca e não só em atividades correlatas, como conserto de redes e processamento de pescado. Dada a relevância e as peculiaridades desta participação, políticas de apoio específicas voltadas para esta parcela têm sido propostas em países da África, visando a equidade no tocante ao acesso aos recursos pesqueiros (FAO, 2007). No Brasil, as mulheres vêm conquistando espaço nas pescarias, ganhando visibilidade, 
apresentações de propostas e ações e assumido cargos de representação do setor (Cardoso, 2001).

A célula familiar do pescador artesanal de Barra Bonita tinha como características principais a presença de dois dependentes, frutos de relações estáveis que mantinham com suas/seus companheiras(os). Este tipo de relação e a presença de dependentes também foram predominantes nos registros de Maruyama (2007) (Médio Tietê: 67,5\% de pessoas casadas, 3 a 4 dependentes), de Ceregato (2001) (Complexo de Urubupungá: 81,7\% e 75,3\% de pessoas casadas em ambas coletas de dados, com 2,9 a 3,6 dependentes), e de MinteVera (1997) e Petrere et al (2007) para a represa Billings (74,0\% e 61,2\%, respectivamente).

Os entrevistados apresentavam baixa escolaridade, com registros de Ensino Básico incompleto para os homens e a mesma etapa completa para as mulheres. A opção pela atuação em atividades pesqueiras pode ser um reflexo desta baixa escolaridade, uma vez que os muitos trabalhadores que atuam em áreas rurais não conseguem empregos em centros urbanos, cuja escolaridade exigida é maior, e optam pelas atividades do campo. Os pescadores artesanais entrevistados por Okada et al. (1997) nos reservatórios de Salto Santiago e Salto Osório (PR) possuíam instrução formal, incompleta, até o grau primário (nível fundamental) e acreditavam que um maior grau de instrução para seus filhos os ajudaria, no futuro, a obter empregos mais rentáveis do que as pescarias, fato observado também no reservatório de Itaipu por Agostinho et al. (1999). Como opção para melhorar o meio de vida e as comunidades dos pescadores, estudos da FAO (2009d) sugerem iniciativas que estejam além das intervenções diretas na atividade pesqueira e mencionam programas de alfabetização e educação dos pescadores.

\subsubsection{Estrutura domiciliar}

Os pescadores entrevistados eram provenientes de outras cidades do estado de São Paulo, principalmente de municípios como Santa Maria da Serra, Piracicaba e São Paulo. Os oriundos dos dois primeiros municípios citados tinham uma característica particular que os diferia dos demais pescadores entrevistados em Barra Bonita: viajavam todos os dias rumo à represa de Barra Bonita para desempenho de seus trabalhos ou mantinham domicílios em ambos locais, passando os dias úteis às margens da represa e os finais de semana em seus municípios de origem. Os demais pescadores (do município de São Paulo, dos demais 
municípios paulistas e dos outros Estados) afirmaram "migrar" em busca de represas com produções pesqueiras mais elevadas, fato mencionado por Petrere et al (2006). Alguns pescadores de outros Estados narraram que, devido ao alto investimento na mudança para a represa de Barra Bonita, ainda não teriam conseguido efetuar investimentos em petrechos de pesca, embarcação e moradia, por exemplo, e dependeriam de seus empregadores para acesso não só ao material necessário para desempenho de seu trabalho, mas também à moradia e à alimentação.

Apesar do tempo de residência no entorno da represa ter sido baixo (1 a 10 anos), houve menções às práticas de subsistência pelo cultivo da terra e pela criação de animais para abate, que pode ser tomada como indicadora de ligação do homem ao campo ou dos anseios dos pescadores em permanecerem no local (Eid et al, 1998). Estudos da FAO (2009d) sugerem que uma das maneiras de fixar o pescador à terra seria concedendo-lhe o direito de propriedade do local em que está assentado. Este direito poderia garantir o acesso a infraestrutura pública básica (saneamento, escola, hospitais) e conseqüentemente reduzir sua condição de pobreza.

A maior parte dos pescadores que afirmou viver em casa própria considerou construções alternativas, como barracos em locais invadidos, e como reflexo disso, foram apontados os usos de lona, lixa e plástico, por exemplo, como materiais de construção. Esta precariedade das moradias é reflexo das sucessivas mudanças de cidades/represas em busca de produções pesqueiras mais elevadas e acarretam um acúmulo pequeno, senão negativo, de capital e patrimônio. Apesar dessa situação de moradia, os pescadores tinham acesso a energia elétrica e utilizavam gás como combustível principal para cocção de alimentos. 0 acesso a energia elétrica possibilita a aquisição de aparelhos domésticos e eletro-eletrônicos, como indicou a análise de patrimônio. Esta análise foi considerada uma referência para a avaliação do padrão de conforto por Walter (2000), mas o acesso a bens e serviços tem se alterado entre a população de baixa renda (ver análise Econômica das Pescarias, capítulo 4) e esta mudança no padrão de consumo é um reflexo do crescimento na oferta de crédito (aumento do crédito direto ao consumidor, crescimento do crédito consignado em conta corrente, por exemplo), como analisaram Torres et al (2006). Okada et al (1997) acreditam ainda que o acesso à energia elétrica permite a conservação e o armazenamento do pescado e, consequentemente, a comercialização com melhores valores. Apesar destas evidências, 
Mendonça (2006) não vê no acesso aos bens de consumo modernos um elemento provocador de mudanças/melhoras na vida do pescador.

Os questionamentos sobre saneamento forneceram respostas sobre a atual situação da distribuição de água, coleta de esgoto e de resíduos sólidos no entorno da represa de Barra Bonita, onde apenas pequenas parcelas dos pescadores relataram ter acesso à água tratada, ao despejo de esgoto doméstico em rede de captação e à coleta e destino final dos resíduos sólidos. Estas deficiências na infaestrutura dos domicílios dos pescadores podem acarretar:

(i) Problemas ambientais:

a. Contaminação do solo causada pela deposição dos resíduos sólidos, uma vez que o lixo descartado/queimado pode conter agentes contaminantes potencialmente tóxicos aos pescadores, aos animais criados e à lavoura de subsistência. Além disso, os pescadores mencionaram o diagnóstico de problemas de saúde relacionados à falta de higiene (alergias e micoses);

b. Contaminação da água, prejudicando os pescadores que a utilizam para lazer, higiene, consumo, além da pesca. Ressalta-se ainda que a maior parte dos pescadores entrevistados não aplica nenhum tratamento à água para o consumo, independente de sua origem e, mais uma vez, os problemas de saúde relacionados à falta de higiene (vermes);

c. Proliferação de insetos, animais peçonhentos e outros animais transmissores de doenças.

(ii) Problemas econômicos: perda do potencial turístico da represa, que já recebe turistas e pescadores esportivos;

As estatísticas oficiais (IBGE, 2000) se referem à freqüência de ocorrência de domicílios com acesso aos serviços estruturais na zona rural (Tabela 10) e estes registros foram inferiores aos indicados pelos pescadores, podendo ser justificados por (i) pelo tipo de informação disponibilizada, podendo estar defasada em relação ao período de estudo e (ii) pelo tipo de domicilio dos pescadores, muitas vezes construídos em áreas invadidas e, por não possuírem registro legal, deixam de ter acesso aos serviços públicos prestados. Apesar dos registros dos pescadores terem ficado acima dos descritos oficialmente, a situação ainda é indesejável e, como solução, vale lembrar os estudos de Salati (2006) ao destacar a eficiência de sistemas combinados de áreas alagadas construídas no tratamento de água e 
de efluentes, e esta poderia ser uma alternativa viável para o desenvolvimento da população pesqueira do entorno da represa de Barra Bonita.

Tabela 10: Estatísticas oficiais sobre a situação do saneamento (abastecimento de água canalizada, coleta de esgoto e coleta de lixo) dos municípios banhados pelas águas da represa de Barra Bonita e das zonas rural e urbana do estado de São Paulo (valores obtidos a partir de IBGE, 2010).

\begin{tabular}{l|llll}
\hline & $\begin{array}{l}\text { Abastecimento de água canalizada } \begin{array}{l}\% \text { de } \\
\text { domicílios) }\end{array} \\
\text { Barra Bonita }\end{array}$ & $\begin{array}{l}\text { Coleta de esgoto } \\
\text { domicílios })\end{array}$ & $\begin{array}{l}\% \text { dos Coleta de lixo } \\
(\%)\end{array}$ \\
$\begin{array}{l}\text { Mineiros do Tietê } \\
\text { Dois Córregos }\end{array}$ & 0,10 & 0,03 & 0,97 \\
Santa Maria da & 1,41 & 0,06 & 0,03 \\
Serra & 4,88 & 0,77 & 2,75 \\
São Pedro & 5,66 & 0,16 & 5,89 \\
Piracicaba & 0,80 & & \\
Anhembi & 0,46 & 0,79 & 10,49 \\
Botucatu & 0,28 & 0,20 & 1,73 \\
São Manuel & 0,38 & 0,38 & 5,09 \\
Igaraçu do Tietê & 0,02 & 0,01 & 0,77 \\
\hline SP - Zona rural & 2,07 & 0,44 & 2,26 \\
\hline SP - Zona urbana & 91,44 & 0,02 & 0,03 \\
\hline
\end{tabular}

O registro de animais silvestres forneceu informações sobre o tipo de relação e exploração do ambiente natural. Comparando os avistamentos de capivara mencionados e o uso destes animais, chegou-se à relação de 13,6\% animais consumidos após avistamentos. Este pode ser um indicativo da relação de exploração do meio ambiente e/ou dos baixos rendimentos econômicos dos pescadores, levando-os a complementar sua dieta com caça. $\mathrm{O}$ conhecimento e a ligação do homem ao campo puderam ser traduzidos pelo uso da vegetação do entorno, expressos segundo o conhecimento e exploração da vegetação para fins medicinais, principalmente. Esta relação pode trazer benefícios aos pescadores, dadas as distâncias dos locais das entrevistas aos municípios onde há centros de atendimento médico.

Apesar de alguns pescadores terem apontado a dependência de patrões/peixeiros para acesso aos alimentos consumidos, quase todos os itens alimentares constantes nos questionários faziam parte da dieta diária da maioria dos pescadores e o consumo dos peixes capturados na represa esteve associado, principalmente, aos pescadores com menor rendimento econômico (ver Análises Econômicas no capítulo 4). Estudos da FAO (2009d) indicam que muitas comunidades pesqueiras artesanais são pobres e vulneráveis, mas que a atividade pesqueira possibilita a segurança alimentar e a mitigação da pobreza, no que diz respeito: 
(i) Às pessoas diretamente envolvidas na atividade pesqueira, em atividades prévias e posteriores à captura;

(ii) Aos que dependem dos pescadores (família e comunidade pesqueira);

(iii) Consumidores;

(iv) Aos que se beneficiam da renda e de empregos ligados à pesca;

(v) Aos que se beneficiam indiretamente do capital movimentado em escala nacional ou internacional (via exportação) e outros mecanismos macroeconômicos.

Apesar da falta de infra-estrutura já discutida, os pescadores foram mais enfáticos ao apontar os aspectos favoráveis da região do que os desfavoráveis. Estes estiveram relacionados à deficiência dos serviços prestados, como transporte e qualidade da água para consumo para consumo, por exemplo.

Em síntese, é possível afirmar que a maior parte dos pescadores entrevistados na represa de Barra Bonita ainda se encontrava presa a um ciclo de pobreza. Este é um reflexo do acesso precário aos serviços públicos, como educação, saneamento e saúde, embora o acesso à alimentação de boa qualidade ainda estivesse garantido. Este e outros aspectos do modo de vida dos pescadores da represa de Barra Bonita ainda serão abordados nos capítulos 5 e 6 . 


\section{CAPITULO 3}

\section{CARACTERIZAÇÃO DAS PESCARIAS ARTESANAIS DE BARRA BONITA}

\subsection{INTRODUÇÃO}

A caracterização e os aspectos quantitativos das pescarias artesanais em represas são importantes por deles dependerem o planejamento e o sucesso da atividade. Esta é considerada complexa e pode ser controlada por processos ambientais e fatores como as variações climáticas e os ciclos de inundação. Por estes motivos, as avaliações dos recursos pesqueiros continentais não devem ser realizadas com base apenas nas pressões de pesca, mas também nos fatores acima e nos efeitos antropogênicos sobre o ecossistema (FAO, 2009d).

As lacunas existentes nos monitoramentos das pescarias artesanais tem sido preenchidas por iniciativas como:

(i) Projeto "Manejo dos Recursos Naturais da Várzea" (ProVárzea), executado pelo IBAMA, cujo objetivo é monitorar as capturas nos principais locais de desembarques pesqueiros ao longo dos rios Amazonas e Solimões, e visa fornecer subsídios para o ordenamento pesqueiro na região (Ruffino, 2006);

(ii) Projeto "Administração dos Recursos Pesqueiros do Médio Amazonas: Estados do Pará e Amazonas" (projeto IARA), executado pelo IBAMA, cujo objetivo é criar um 
banco de dados que integre as áreas de gestão participativa, organização comunitária, comunicação social, educação ambiental, biologia e ecologia das espécies de peixes, aspectos sócio-econômicos das populações ribeirinhas e dos pescadores e tecnologia da pesca e do pescado. Esta integração visa dar suporte à adoção de medidas de manejo para as pescarias praticadas aos logo do Rio Amazonas (Isaac et al , sem data);

(iii) “Desenvolvimento da Pesca Interior no Estado de São Paulo", executado desde 1992 pelo Instituto de Pesca, objetivando o mapeamento da situação da pesca continental no Estado (Castro, sem data).

Castro (sem data) apresentou os pontos críticos da pesca continental no Estado de São Paulo, considerando-os semelhantes à realidade brasileira: (1) falta de clareza nas Leis e Portarias, possibilitando diferentes interpretações; (2) higiene precária no preparo e conservação do pescado; (3) carência de políticas públicas visando a implantação de entrepostos pesqueiros; (4) falta de organização associativa e maior apoio das Colônias às comunidades de pescadores artesanais profissionais; (5) necessidade de um cadastramento do número de pescadores artesanais profissionais efetivos junto às Colônias de Pescadores; (6) necessidade de um melhor aproveitamento dos resíduos produzidos no processamento do pescado, e (7) conflitos entre a pesca profissional e a amadora.

A pesca em território paulista é regulamentada pela Lei № 11.165, de 27 de junho de 2002, que instituiu o Código de Pesca e Aqüicultura do Estado e considerou a pesca artesanal "aquela praticada diretamente por pescador profissional, de forma autônoma, em regime de economia familiar ou em regime de parceria com outros pescadores, com finalidade comercial".

\subsection{OBJETIVOS}

- Descrever a pescaria artesanal, no que se refere aos tipos de embarcações utilizadas, às artes de pesca empregadas, ao número de pessoas envolvidas na atividade;

- Verificar a composição especifica e o desembarque da comunidade de peixes capturados pelos pescadores artesanais de Barra Bonita;

- Verificar as áreas mais produtivas da represa. 


\subsection{METODOLOGIA}

\subsubsection{Levantamento da atividade pesqueira}

As variáveis qualitativas referentes aos equipamentos de pesca foram analisadas em relação ao ambiente (zona da represa) e à sazonalidade (estações seca e chuvosa).

\subsubsection{Captura}

As capturas foram expressas em relação à sazonalidade e ao ambiente ( $Y w_{\text {season,zone }} \mathrm{e}$ $\left.Y w_{\text {esp,season,zone }}\right)$. As capturas totais foram obtidas por dia de pescaria $(Y w$, em $\mathrm{kg}$ ) e as informações detalhadas por espécie ( $Y w_{\text {esp }}$, em $\mathrm{kg}$ ), em relação à semana anterior às entrevistas. No entanto, alguns pescadores tiveram dificuldade em informar as capturas médias diárias e, para validar as informações sobre capturas, foi aplicada uma análise de correlação entre as capturas semanais (soma de todas as espécies mencionadas) e as capturas diárias.

\begin{tabular}{|c|c|}
\hline Indice & Onde: \\
\hline$Y w_{\text {season,zone }}(1)$ & $\begin{array}{l}Y w_{\text {season,zone é a captura total diária }(\mathrm{kg}) \text { por estação do ano e zona da represa, expressa em }} \\
\text { termos do somatório das capturas diárias informadas pelo pescador }(\mathrm{kg})\end{array}$ \\
\hline $\begin{array}{l}Y w_{\text {esp }, \text { season,zone }} \\
\text { (2) }\end{array}$ & 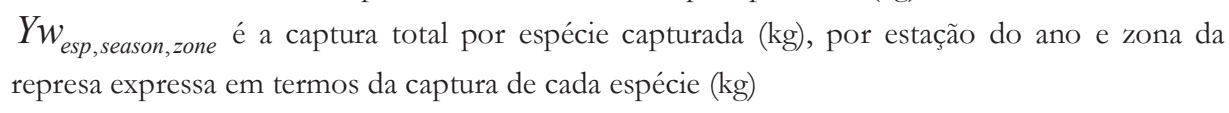 \\
\hline$Y w_{\text {esp }, \text { total }}(3)$ & $Y w_{\text {esp,total }}$ é o somatório de todas as espécies capturadas na semana anterior $(\mathrm{kg})$ \\
\hline
\end{tabular}

\subsubsection{Esforço de pesca}

O esforço de pesca foi obtido em termos do número de horas de pescaria por dia $\left(f_{\text {day }}\right)$ e em termos de número de dias de pesca por semana $\left(f_{\text {week }}\right)$ (Petrere, 1978). Ambos foram calculados de acordo com as estações do ano e zonas da represa:

\begin{tabular}{l|l} 
Índice & Onde: \\
\hline$f_{\text {day,season,zone }}$ & $f_{\text {day,season,zone é o esforço de pesca diário por estação do ano e zona da represa expresso em }}$ \\
$(4)$ & termos do número de horas de trabalho por dia de pesca, por estação do ano e zona da represa \\
$f_{\text {week,season,zone }}$ & $f_{\text {week,season,zone é o esforço de pesca semanal por estação do ano e zona da represa expresso em }}$ \\
$(5)$ & termos do número de dias de pesca por semana, por estação do ano e zona da represa
\end{tabular}




\subsubsection{Análise de esforço e captura}

A cpue (çaptura por unidade de esforço) teoricamente é um índice proporcional à quantidade média de indivíduos de tamanho capturável presente numa área num período de tempo. O estoque capturável representa uma parte do estoque disponível, ou seja, uma parte dos indivíduos de uma população que apresenta idade/ comprimento vulneráveis ao aparelho de pesca (Fonteles Filho, 1989). Este índice deveria ser usado quando as capturas apresentassem relação linear com o esforço de pesca e a reta passar pela origem (Gulland, 1954). Mas na maioria das vezes esta precaução não é tomada.

A avaliação entre a captura e o esforço de pesca para pesca artesanal foi realizada através de um gráfico da captura $X$ esforço e este foi inspecionado para decidir se a relação era linear. Graficamente, a captura e o esforço foram expressos de acordo com as equações abaixo:

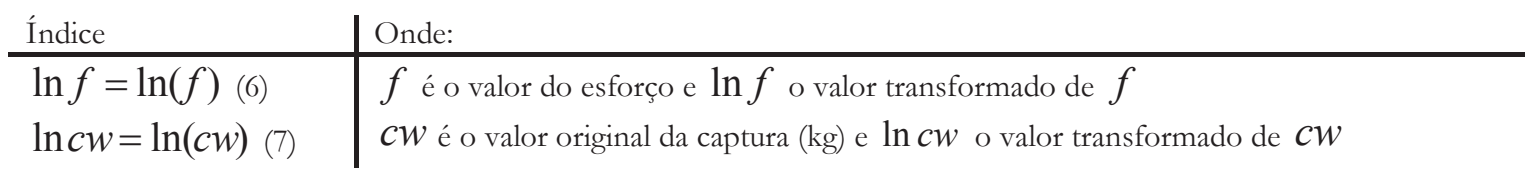

A análise de regressão foi aplicada conforme o modelo abaixo, com nível de confiança $1-\alpha=0,95$.

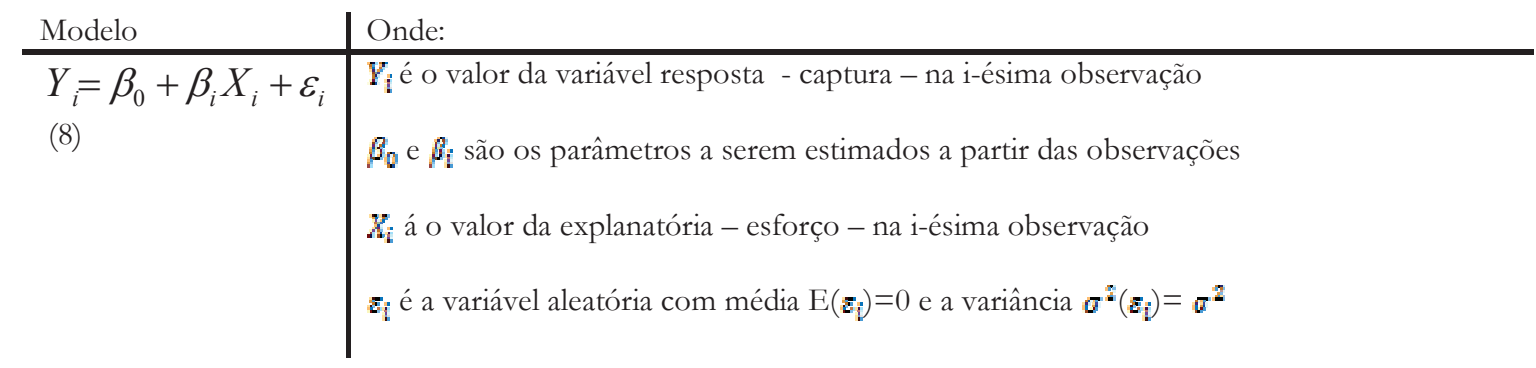

\subsubsection{Análise estatística}

A partir dos dados coletados, buscou-se detectar os fatores estatisticamente significativos $(p<0,05)$ sobre as capturas da represa de Barra Bonita. Para tanto, foi testado um modelo de ANCOVA sobre os dados das capturas, dos esforços e dos possíveis fatores que têm efeito na pescaria artesanal (Huitema, 1980). 
Apesar das transformações, alguns resultados de $\ln Y w$ foram zero, tendo sido desconsiderados nas análises. As análises têm caráter exploratório, ao tentar se entender a estrutura de correlação entre as variáveis do modelo, em busca de um modelo mínimo que melhor a explique. Assim os fatores e sua interação, quando não significativos em nível de $5 \%$ foram sucessiva e automaticamente desconsiderados do modelo.

No modelo testado inicialmente (Equação 9) foram considerados os fatores definidos a seguir.

$$
\ln Y w=\mu+Z+S+Z * S+\ln f+\varepsilon(9)
$$

\begin{tabular}{l|l} 
Índice & Onde: \\
\hline Fatores & $\begin{array}{l}\text { S: Estação do ano, onde dry= seca e rainy=chuvosa } \\
\text { Z: zona da represa, onde RP é a zona fluvial/braço Piracicaba, RT é a zona fluvial/braço Tietê, TRANS }\end{array}$ \\
$\begin{array}{l}\text { é a zona de transição e LAKE é a zona lacustre } \\
\text { lnf: esforço pesqueiro logaritmizado, em termos de número de dias de pescaria por semana }\end{array}$ \\
\hline
\end{tabular}

A verificação da normalidade das variáveis foi testada utilizando-se o teste de Lilliefors (Legendre \& Legendre, 1998).

Para a comparação entre as médias foi executado um teste LSD com os pares de médias ajustadas ao nível de significância de 5\%, apenas para o modelo final, entre as médias ajustadas das zonas da represa, em relação à sazonalidade, de acordo com a equação 10 (Huitema, 1980). Assim, para cada par de médias obtidas para as zonas da represa, foram calculados:

$$
\begin{aligned}
& M S E=\frac{S S E}{(/-1)(K-1)}(10) \\
& t=\frac{r_{\mathrm{i}}-\mathrm{F}_{j}}{\sqrt{\operatorname{MSE}\left[\left(\frac{1}{\eta_{i}}\right)+\left(\frac{1}{\eta_{j}}\right)\right]}}(11)
\end{aligned}
$$

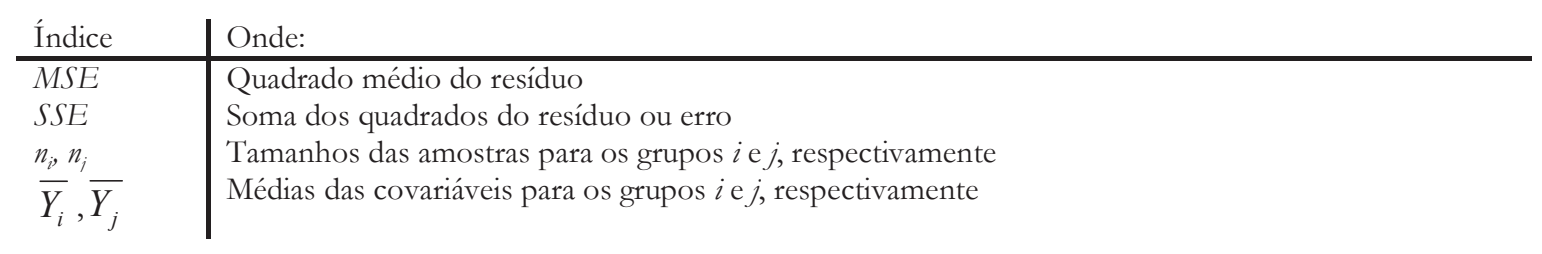

Os dados foram analisados com o programa SYSTAT 11 (SYSTAT, 2004, versão demo). 


\subsection{RESULTADOS}

\subsubsection{Atividade pesqueira}

A atividade era praticada pelos pescadores entrevistados na estação seca, zona lacustre havia 17,3 anos, em média. Os pescadores com menor tempo médio de experiência foram entrevistados na estação chuvosa, zona de transição (Tabela 11.)

Todos os pescadores afirmaram atuar apenas na represa de Barra Bonita e as pescarias praticadas em outros locais estiveram associadas aos municípios/Estados em que moraram anteriormente (Capítulo 2, Figura 5). A existência de locais pré-determinados para as pescarias não foi identificada e a escolha dos locais se dava por ordem chegada aos pontos de pesca. Além disso, as distâncias percorridas pelos pescadores eram pequenas, devido à baixa autonomia dos barcos, e sua distribuição esteve sempre associada aos agrupamentos de pescadores.

Tabela 11: Tempo de experiência na atividade pesqueira para os pescadores de Barra Bonita.

\begin{tabular}{|c|c|c|c|c|c|c|c|c|}
\hline \multirow{3}{*}{ Experiência (anos) } & \multicolumn{4}{|c|}{ Estação chuvosa } & \multicolumn{4}{|c|}{ Estação seca } \\
\hline & \multicolumn{4}{|c|}{ Zona } & \multicolumn{4}{|l|}{ Zona } \\
\hline & RP & RT & Trans & Lake & RP & RT & Trans & Lake \\
\hline Media & 12,6 & 6,9 & 14,5 & 8,0 & 11,9 & 12,7 & 7,6 & 17,3 \\
\hline Mín & 0 & 1,0 & 6,0 & 2,0 & 2,0 & 5,0 & 2,0 & 4,0 \\
\hline Máx & 39,0 & 25,0 & 35,0 & 20,0 & 35,0 & 40,0 & 25,0 & 51,0 \\
\hline $\mathrm{CV}$ & 0,74 & 0,64 & 0,74 & 0,61 & 0,81 & 1,07 & 0,98 & 1,00 \\
\hline
\end{tabular}

Durante a seca um único barco de fibra pescou na zona lacustre, e a maioria dos barcos de madeira foi registrada durante a estação seca. As embarcações de alumínio, utilizadas preferencialmente $(n=115)$, foram registradas em ambas estações do ano e em todas as zonas da represa. A maior parte dos pescadores afirmou ser a dona dos barcos ( $n=113$ ) e dois pescadores da zona fluvial/braço Piracicaba pescavam com barcos do peixeiro. Três pescadores das duas zonas fluviais pescavam com redes de seus patrões, dois do braço Tietê (um na estação seca e outro, na chuvosa) e um no braço Piracicaba (estação seca). As embarcações tinham, preferencialmente, entre 4,0 a 6,0m e 6,0 a 7,0m de comprimento e foram registradas em todos os locais de entrevistas e em ambas as estações. Em relação aos petrechos de pesca, todos utilizavam rede de espera e dois pescadores mencionaram a pesca de arrasto, mas não forneceram informações detalhadas sobre esse tipo de rede. A 
pesca de batida ${ }^{3}$ foi apontada por 32 pescadores que afirmaram utilizar as redes de espera para esta prática. Quanto à propriedade dos petrechos, os pescadores utilizavam petrecho próprio $(n=113)$, dividiam com amigos ou parentes $(n=4)$ ou utilizavam petrecho do patrão/peixeiro $(n=5)$. Os pescadores que possuíam um maior número de redes foram entrevistados durante a estação seca, nas zonas fluviais. O uso de redes de maior tamanho foi apontado durante a estação seca, zona fluvial/braço Tietê $\left(C_{\text {méd }}=161 m ; n=5 ; s=273,436\right)$. A maior parte dos pescadores utilizava redes com abertura de malha de 90 e $100 \mathrm{~mm}$ entre nós opostos. As indicações dos usos das menores (30 e $40 \mathrm{~mm}$ entre nós opostos) e da maior abertura de malha (300mm entre nós opostos) foram apontadas na zona fluvial/braço Piracicaba, nas estações chuvosa e seca, respectivamente (Tabela 12).

\subsubsection{Composição da captura}

Durante o período de estudo, foram mencionadas 14 espécies de peixes, mas como não houve acesso às capturas, conseqüentemente a identificação e confirmação de seus nomes científicos não foi possível. Assim, optou-se por apresentar os nomes científicos segundo cada indicação dos nomes vulgares dos peixes. As espécies capturadas estão distribuídas em três ordens e nove famílias, conforme a listagem taxonômica abaixo (Tabela 13).

As capturas médias diárias e totais semanais mais elevadas foram obtidas na estação chuvosa, zona fluvial/braço Piracicaba ( $Y w_{\text {season,zone }}=103,36 \mathrm{~kg} ; \mathrm{n}=22 ; \mathrm{s}=73,13$ ) e estação seca, zona de transição $\left(Y w_{\text {esp,season,zone }}=497,80 \mathrm{~kg} ; \mathrm{n}=6 ; \mathrm{s}=160,129\right)$, respectivamente. As menores capturas médias, tanto diárias quanto totais semanais, foram registradas na estação seca, zona lacustre ( $Y w_{\text {season,zone }}=37,70 \mathrm{~kg} ; \mathrm{n}=10 ; \mathrm{s}=26,37$; e $Y w_{\text {esp } \text {,season,zone }}=139,33 \mathrm{~kg} ; \mathrm{n}=6 ; \mathrm{s}=132,63$ ) (Tabela 14).

\footnotetext{
${ }^{3}$ Pesca de batida: forma ativa de pesca. A eficiência da pesca de batida é garantida devido ao barulho produzido na água, que desorienta o peixe, que nada em direção a rede
} 


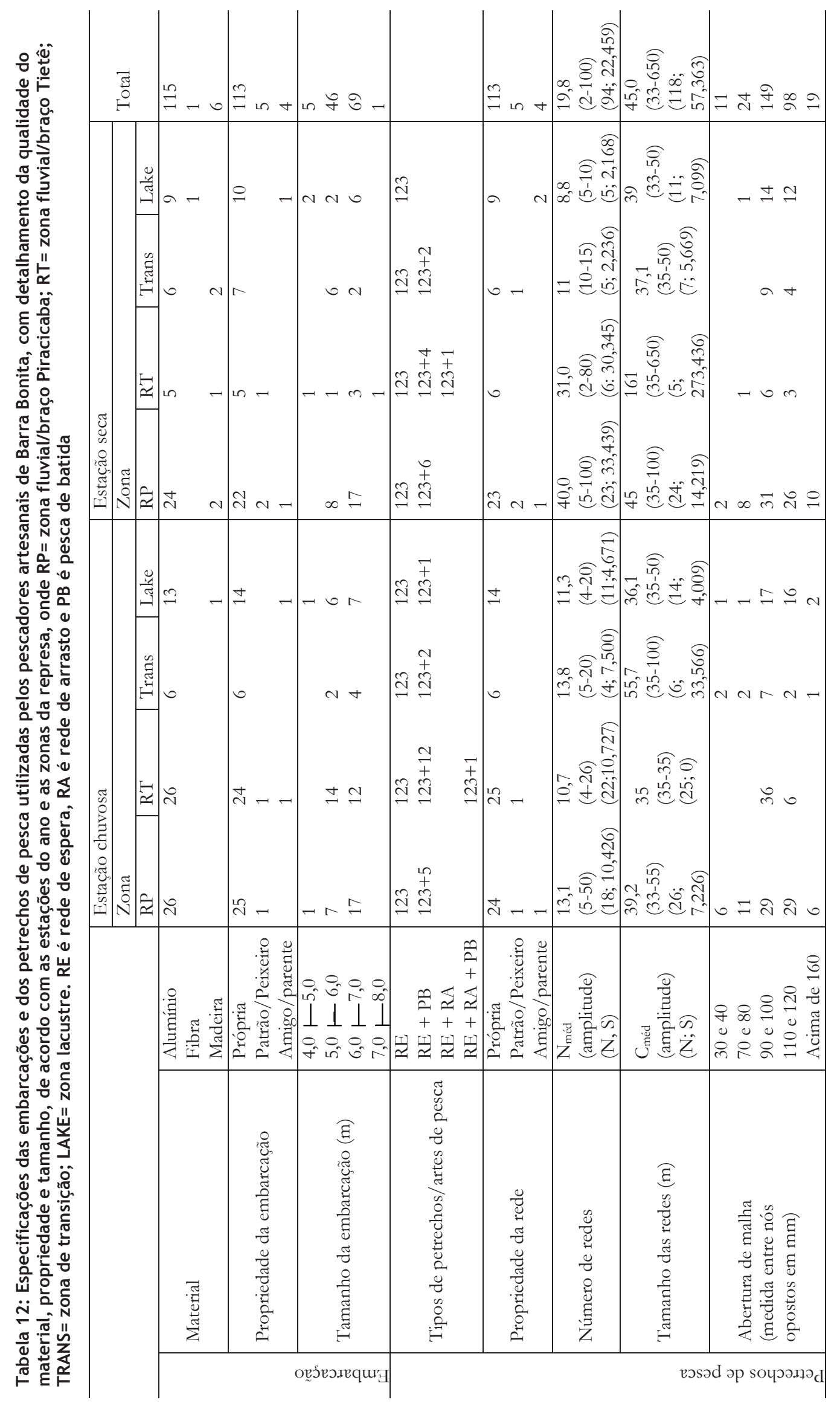


Tabela 13: Espécies de peixes encontradas na represa de Barra Bonita.

\begin{tabular}{|c|c|c|c|}
\hline \multirow[t]{14}{*}{ Characiformes } & Anostomidae & Leporinus obtusidens & Piapara \\
\hline & Anostomidae & Leporinus sp & Piau \\
\hline & Characidae & Astyanax altiparanae & Tambiú \\
\hline & Characidae & Astyanax fasciatus & Lambari de rabo vermelho \\
\hline & Characidae & Astyanax schubarti & Lambari prateado \\
\hline & Characidae & Moenkhausia intermedia & Viuvinha, lambari corinthiano \\
\hline & Characidae & Salminus brasiliensis & Dourado \\
\hline & Characidae & Triportheus paranensis & Sardinha de água doce \\
\hline & Characidae & Piaractus mesopotamicus & Pacu \\
\hline & Characidae & Serrasalmus maculatus & Piranha \\
\hline & Characidae & Serrasalmus spilopleura & Piranha, Pirambeba \\
\hline & Characidae & Metynnis maculatus & Pacu-peva \\
\hline & Erythrinidae & Hoplias malabaricus & Traíra \\
\hline & Prochilodontidae & Prochilodus lineatus & Corimba \\
\hline \multirow[t]{4}{*}{ Siluriformes } & Loricariidae & Liposarcus anisitsi & Cascudo \\
\hline & Loricariidae & Hypostomus ancistroides & Cascudo \\
\hline & Pimelodidae & Pimelodus maculatus & Mandi-amarelo \\
\hline & Heptapteridae & Pimelodella sp. & Mandi-chorão \\
\hline \multirow[t]{4}{*}{ Perciformes } & Cichlidae & Geophagus brasiliensis & Acará, Cará \\
\hline & Cichlidae & Satanoperca jurupari & Acará geo \\
\hline & Cichlidae & Oreochromys niloticus & Tilápia do Nilo \\
\hline & Scianidae & Plagioscion squamosissimus & Corvina, Pescada \\
\hline
\end{tabular}

Fonte: Petesse (2006), modificada.

Tabela 14: Distribuição de captura ( $Y w$, em kg) total diária e total semanal na represa de Barra Bonita, onde RP= zona fluvial/braço Piracicaba; $R T=$ zona fluvial/braço Tietê; TRANS= zona de transição; LAKE= zona lacustre.

\begin{tabular}{|c|c|c|c|c|c|c|c|c|c|}
\hline & \multicolumn{4}{|c|}{ Estação chuvosa } & \multicolumn{4}{|c|}{ Estação seca } \\
\hline & & \multicolumn{4}{|c|}{ Zona } & \multicolumn{4}{|c|}{ Zona } \\
\hline & & $\mathbf{R P}$ & RT & Trans & Lake & RP & RT & Trans & Lake \\
\hline \multirow{5}{*}{$\begin{array}{l}Y w_{\text {season,zone }} \\
(\mathrm{kg})\end{array}$} & Soma & 2340,00 & 2435,00 & 590,00 & 920,00 & 2040,00 & 470,00 & 810,00 & 377,00 \\
\hline & Media & 103,36 & 93,65 & 98,33 & 70,77 & 85,00 & 78,33 & 101,25 & 37,70 \\
\hline & SD & 73,13 & 56,74 & 74,14 & 46,45 & 43,54 & 50,37 & 46,12 & 26,37 \\
\hline & $\mathrm{CV}$ & 0,69 & 0,61 & 0,75 & 0,66 & 0,51 & 0,64 & 0,46 & 0,70 \\
\hline & $\mathrm{N}$ & 22 & 26 & 6 & 13 & 24 & 6 & 8 & 10 \\
\hline \multirow{5}{*}{$\begin{array}{l}Y w_{\text {esp,season,zone }} \\
(\mathrm{kg})\end{array}$} & Soma & 11912,00 & 7232,00 & 1905,00 & 4195,00 & 6744,00 & 1885,00 & 2489,00 & 836,00 \\
\hline & Media & 458,15 & 278,15 & 317,50 & 299,64 & 293,22 & 314,17 & 497,800 & 139,33 \\
\hline & SD & 268,07 & 255,88 & 160,12 & 109,06 & 171,84 & 159,89 & 492,30 & 132,63 \\
\hline & $\mathrm{CV}$ & 0,59 & 0,92 & 0,50 & 0,36 & 0,59 & 0,51 & 0,99 & 0,95 \\
\hline & $\mathrm{N}$ & 26 & 26 & 6 & 14 & 23 & 6 & 5 & 6 \\
\hline
\end{tabular}

As análises conjuntas por estação do ano e zona da represa indicam as maiores capturas absolutas na estação chuvosa, zona fluvial/braço Piracicaba ( $\left.Y w_{\text {esp,season,zone }}=11923 \mathrm{~kg}\right)$, seguidas da estação chuvosa, zona fluvial/braço Tietê $\left(Y w_{\text {esp season,zone }}=7232 \mathrm{~kg}\right)$ e estação seca, zona fluvial $/$ braço Tietê $\left(Y w_{\text {esp }, \text { season, zone }}=6744 \mathrm{~kg}\right.$ ) (Figura 23). A análise por espécie capturada (Figura 24, Tabela 15) indicou que a sardinha $\left(Y w_{\text {sardinha }}=60 \mathrm{~kg}\right.$ ) foi capturada apenas na estação seca, zona fluvial/braço Piracicaba. Apenas a tilápia, a corvina e o mandi foram capturados em todas as zonas e em ambas estações de estudo. 


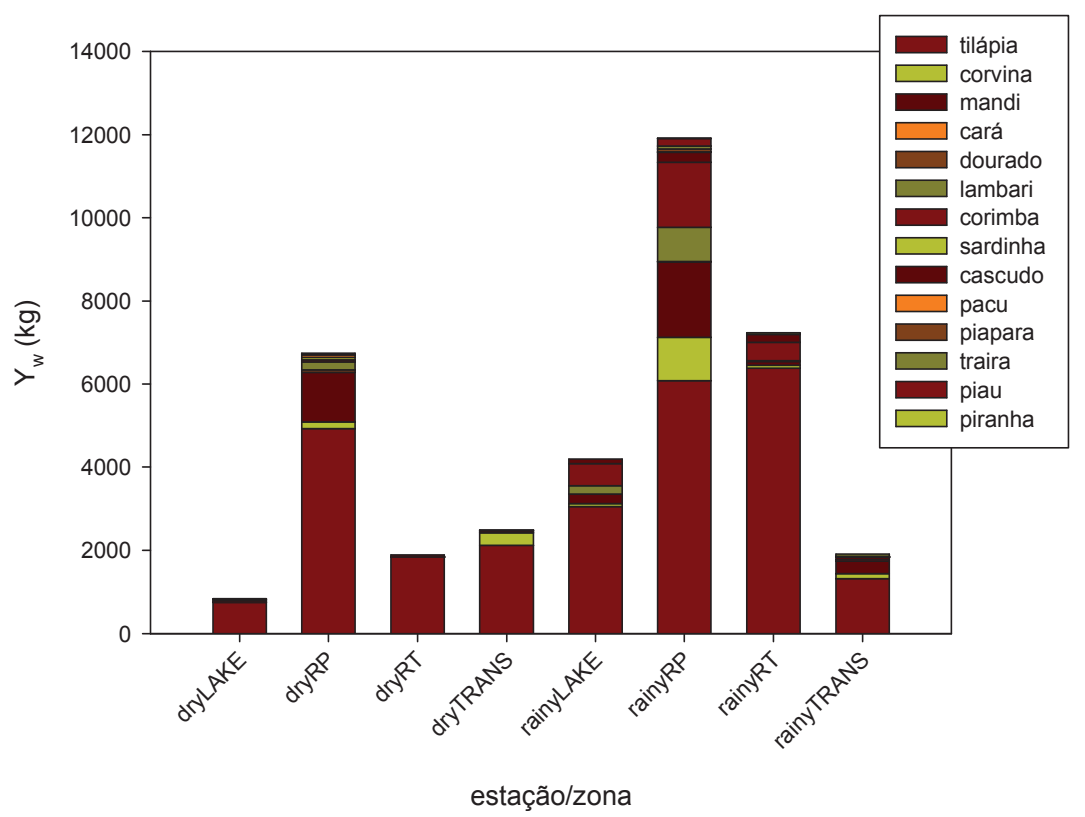

Figura 24: Distribuição de captura absoluta por espécie $\left(\mathrm{Y}_{\mathrm{w}}, \mathrm{kg}\right)$ da represa de Barra Bonita, onde dryLAKE = estação seca, zona lacustre; dryRP= estação seca, zona fluvial/braço Piracicaba; dryRT= estação seca, zona fluvial/braço Tietê; dryTRANS= estação seca, zona de transição; rainyLAKE= estação chuvosa, zona lacustre; rainyRP= estação chuvosa, zona fluvial/braço Piracicaba; rainyRT= estação chuvosa, zona fluvial/braço Tietê; rainyTRANS= estação chuvosa, zona de transição.

Tabela 15: Distribuição das espécies capturadas $\left(Y_{w}\right.$, em $\left.\mathrm{kg}\right)$ na represa de Barra Bonita, onde RP é a zona fluvial/braço Piracicaba; RT é zona fluvial/braço Tietê; Trans é a zona de transição; Lake é a zona lacustre.

\begin{tabular}{|c|c|c|c|c|c|c|c|c|c|}
\hline \multirow{3}{*}{ Espécie } & \multicolumn{4}{|c|}{ Estação chuvosa } & \multicolumn{4}{|c|}{ Estação seca } & \multirow{3}{*}{ Total } \\
\hline & \multicolumn{4}{|l|}{ Zona } & \multicolumn{4}{|l|}{ Zona } & \\
\hline & $\mathrm{RP}$ & RT & Trans & Lake & $\mathrm{RP}$ & RT & Trans & Lake & \\
\hline Piapara & 70 & & 10 & & 10 & & & & 90 \\
\hline Piau & 176 & & & & & & & & 176 \\
\hline Lambari & 820 & & & 200 & 185 & & & & 1205 \\
\hline Dourado & 5 & & & & 60 & & & & 65 \\
\hline Sardinha & & & & & 60 & & & & 60 \\
\hline Pacu & 8 & & & & 60 & & & & 68 \\
\hline Piranha & 9 & 30 & 50 & & & & & & 89 \\
\hline Traíra & 73 & 4 & & & 30 & & & & 117 \\
\hline Corimba & 1596 & 442 & 50 & 535 & 55 & & 2 & & 2653 \\
\hline Cascudo & 242 & 192 & 50 & 110 & & & 13 & 12 & 619 \\
\hline Mandi & 1817 & 89 & 300 & 222 & 1195 & 40 & 50 & 43 & 3759 \\
\hline Cará & & 20 & & & & & & 20 & 40 \\
\hline Tilapia & 6080 & 6380 & 1320 & 3050 & 4930 & 1835 & 2120 & 748 & 26463 \\
\hline Corvina & 1043 & 75 & 115 & 78 & 159 & 10 & 304 & 13 & 1797 \\
\hline Total & 11912 & 7232 & 1905 & 4195 & 6744 & 1885 & 2489 & 836 & 37198 \\
\hline
\end{tabular}



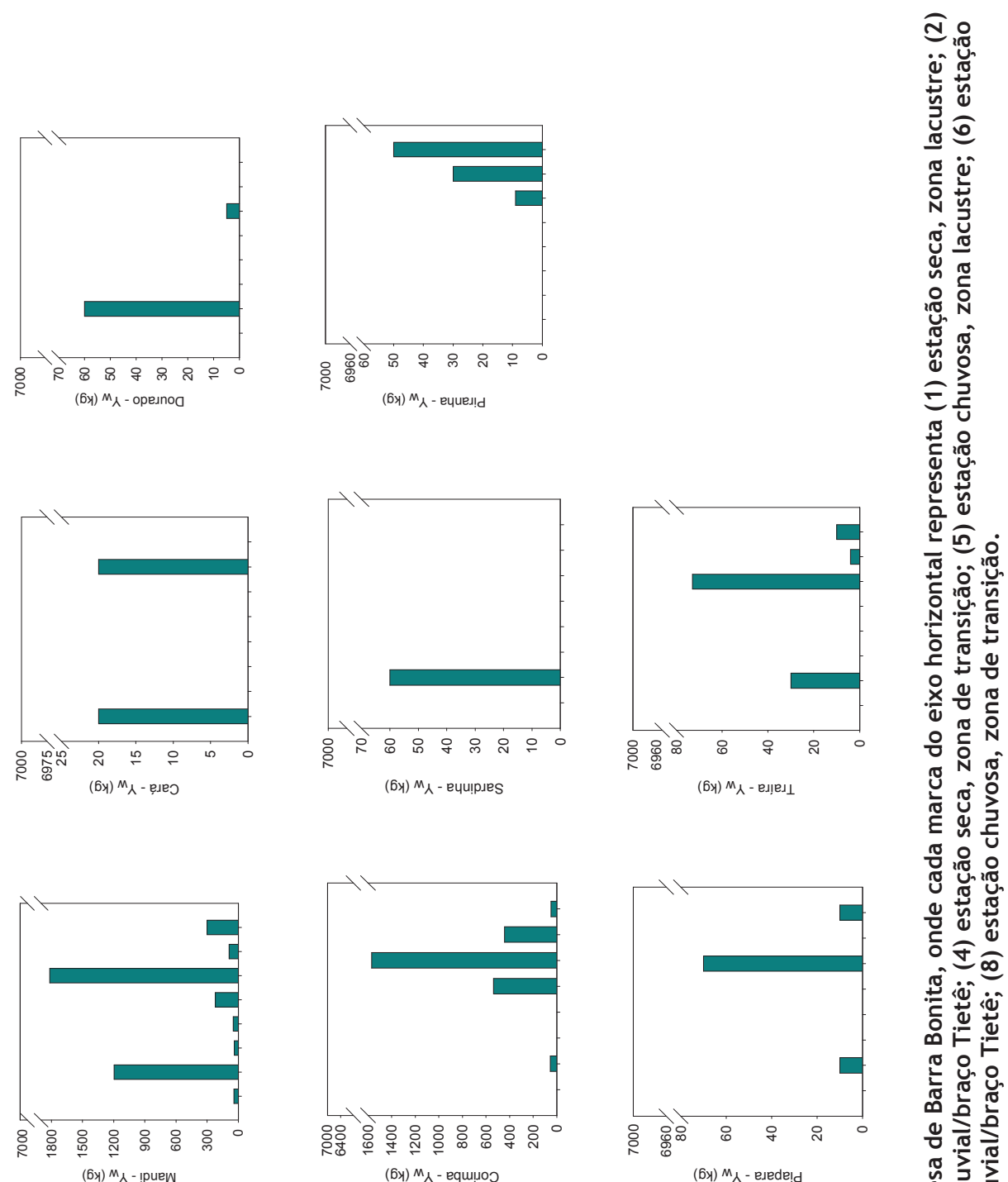

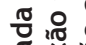

ช 记

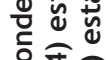

ษ

苍递

问

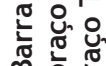

范

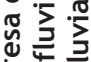

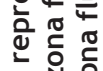
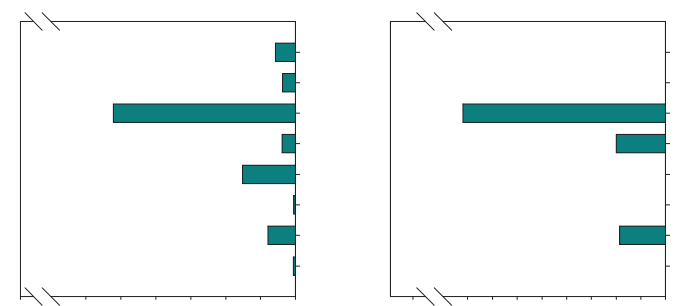

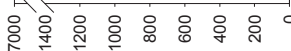

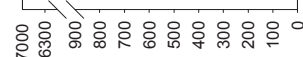

(6у) M人 - вu!nsoJ

(6y) $M_{\text {人 - ! leque }}$

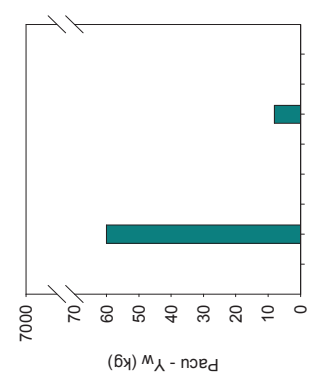

T

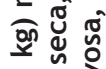

텅원른

入芆苟 :

蔫

突的空

응

幽.

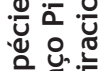

응

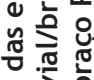
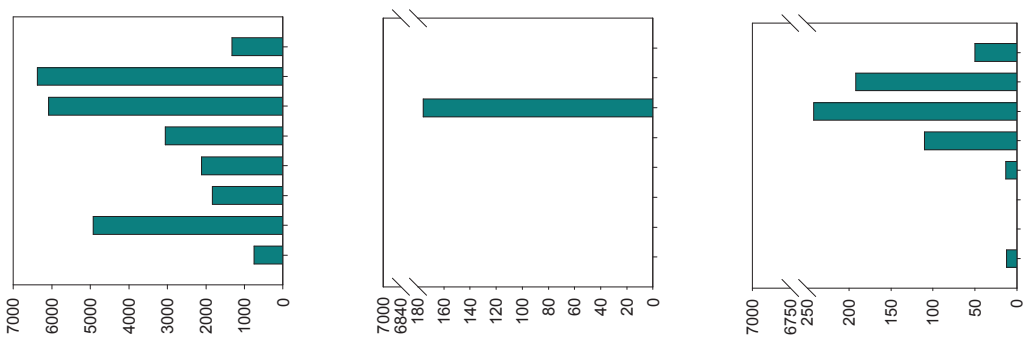

诧究

䓁墕

垔

ํํำ

นู่

닌

总苟焉 
A dispersão entre as variáveis $Y w_{d a y}$ e $Y w_{\text {esp,total }}$ foi examinada através da análise de SPLOM (Scatter PLOt Matrix). Como não houve ajuste linear entre os pontos (Figura 26A), os dados foram transformados para log-log na base $e$ no intuito de linearizar estas relações (Figura 26B). Aos dados transformados foram aplicados testes de correlação e a ausência de outliers foi checada. Apesar das transformações, o baixo valor de $r$ reflete o pequeno ajuste entre as informações das capturas estudadas. Por este motivo, optou-se por utilizar as capturas detalhadas $Y w_{\text {esp.total }}$ e/ou $Y w_{\text {esp }}$ nos estudos subseqüentes.
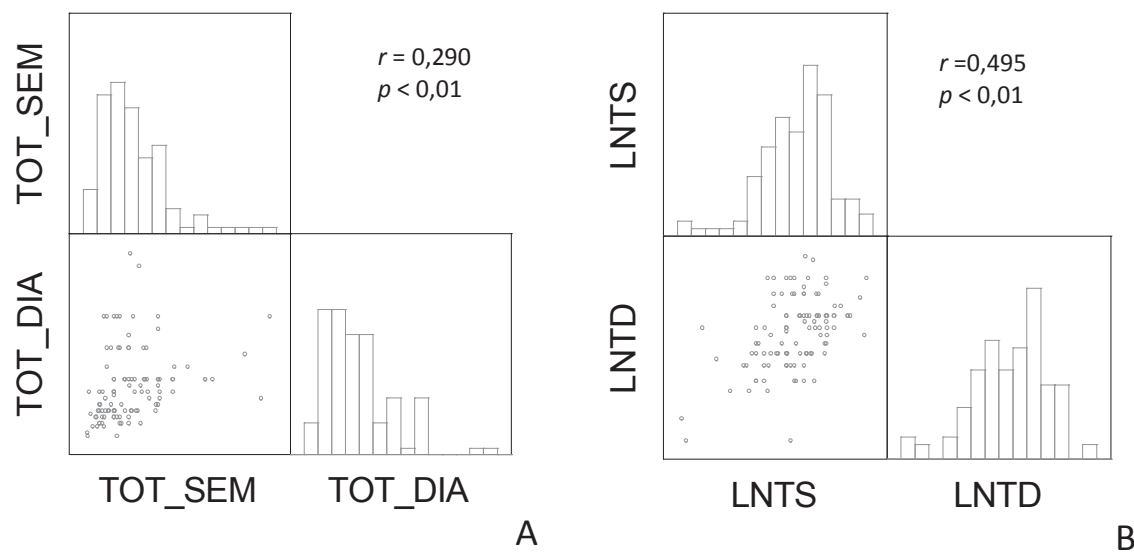

Figura 26: (A) Análise de correlação entre os dados das capturas diárias (TOT_DIA) e a soma das capturas semanais (TOT_SEM), por espécie e (B) Análise de correlação entre os dados logaritimizados das capturas diárias (LNTD) e a soma das capturas semanais por espécie (LNTD).

\subsubsection{Esforço de pesca}

O esforço de pesca médio diário foi de 7,81 horas $(n=122 ; 2,15)$. O maior esforço foi aplicado na estação chuvosa, zona de transição ( $\left.f_{\text {day,season,zone }}=9,17 \mathrm{~h} ; \mathrm{n}=6 ; \mathrm{s}=2,11\right)$ e o menor, na estação seca, zona fluvial/braço Tietê $\left(f_{\text {day,season,zone }}=7,00 \mathrm{~h} ; \mathrm{n}=26 ; \mathrm{s}=2,67\right)$. 0 esforço médio em termos de número de dias por semana foi de 5,98 dias $(n=123 ; s=0,99)$. Os pescadores que se dedicavam às pescarias por mais dias foram entrevistados na estação seca, zona de transição ( $f_{\text {week, } \text {,eason,zone }}=6,71$ dias/semana; $\mathrm{n}=6 ; \mathrm{s}=0,82$ ) e os que se dedicavam por menos dias, na estação seca, zona fluvial/braço Tietê ( $f_{\text {week,season,zone }}=5,50$ dias/semana; $\mathrm{n}=26 ; \mathrm{s}=0,97)$ (Tabela 16). 
Tabela 16: Esforço de pesca dos pescadores de Barra Bonita expresso em termos de número de horas por dia e número de dias por semana, onde RP= zona fluvial/braço Piracicaba; $\mathrm{RT}=$ zona fluvial/braço Tietê; TRANS= zona de transição; LAKE= zona lacustre.

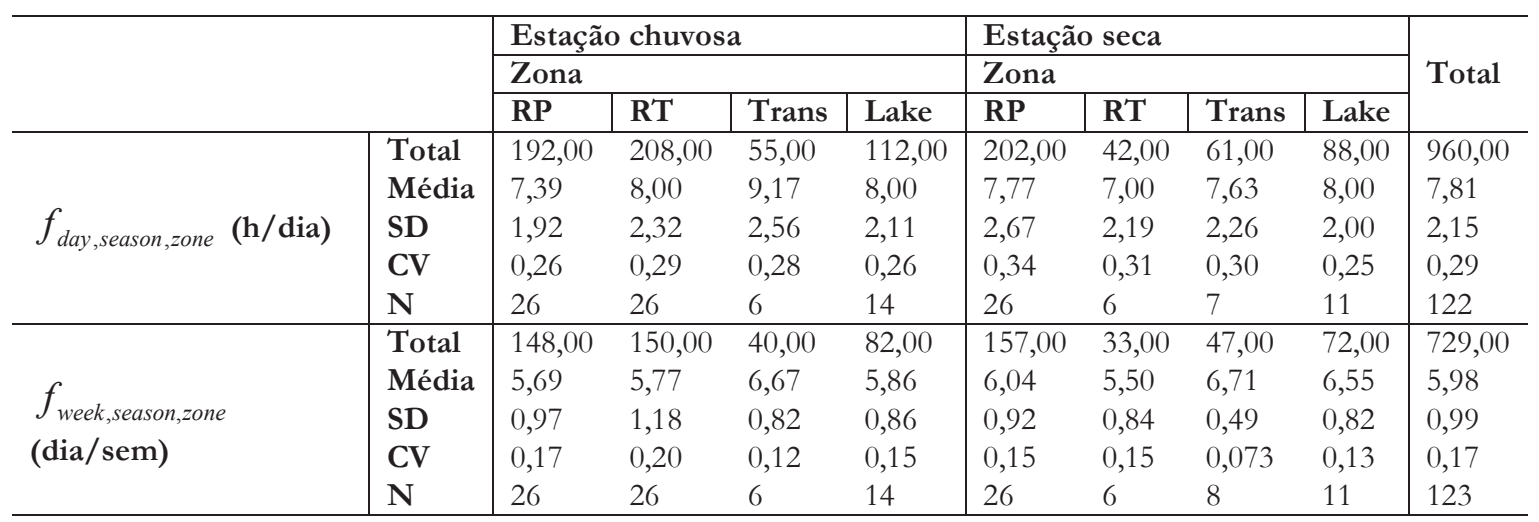

\subsubsection{Análise de cpue}

A produção de pescado apontada pelos pescadores não apresentou relação com o esforço de pesca e, por isso, a cpue não foi utilizada ( $n=108 ; r=0,031 ; r^{2}=0,001 ; F_{1,107}=0,105$; $\mathrm{p}=0,746$ ) (Figura 27).

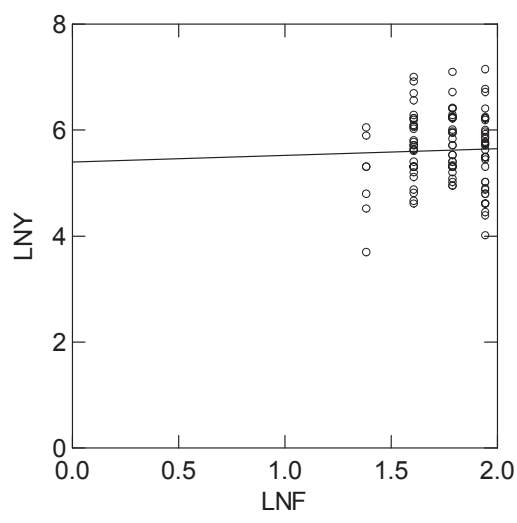

Figura 27: Esforço de pesca (LNF, logaritmo do esforço pesqueiro em termos de número de dias de pescaria na semana) versus captura (LNY, logaritmo da captura em quilogramas).

\subsubsection{Análise estatística}

No modelo testado inicialmente foram considerados $\ln y$ a variável dependente, $\ln f$ a variável independente e os fatores $S$ e $Z$ (estação do ano e zona da represa, respectivamente) conforme a equação $\ln y=\mu+S+Z+S^{*} Z+\ln f+\varepsilon$ (5).

A Tabela 17 apresenta o modelo final da ANCOVA, $\ln y=\mu+S * Z+\varepsilon$, após a retirada dos fatores e da covariável cujos valores de $p>0,05$. 
Tabela 17: Resultados da ANCOVA aplicada no modelo $\ln c w=\mu+Z+S+Z * S+\ln f+\varepsilon$, onde $S$ é a estação do ano (dry=seca e rainy=chuvosa), $Z$ é a zona da represa (RT= zona fluvial/braço Tietê, RP= zona fluvial/braço Piracicaba, TRANS= zona de transição e LAKE=zona lacustre), $Z * S$ é interação de $1^{\text {a }}$ ordem, $\ln f$ é o logaritmo do esforço expresso em termos de dias de pescaria por semana.

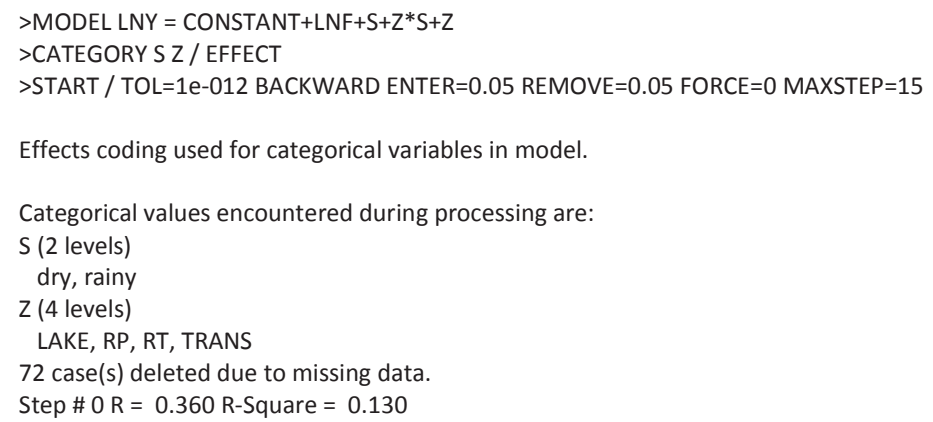

\begin{tabular}{|c|c|c|c|c|c|c|c|c|}
\hline & Effect & Coefficient & Std Error & Std Coef & Tol. & $\mathrm{df}$ & $\mathrm{F}$ & 'P' \\
\hline \multicolumn{9}{|l|}{ In } \\
\hline 1 & Constant & & & & & & & \\
\hline 2 & LNF & 0.212 & 0.391 & 0.053 & 0.91110 & 1 & 0.294 & 0.589 \\
\hline 3 & S & -0.038 & 0.083 & -0.054 & 0.63901 & 1 & 0.213 & 0.645 \\
\hline 4 & z & . & . & - & 0.64897 & 3 & 1.182 & 0.321 \\
\hline 5 & $z^{*} S$ & . & . & . & 0.64700 & 3 & 2.452 & 0.068 \\
\hline Out & None & Part. Corr. & & & & & & \\
\hline
\end{tabular}

>STEP / AUTO

Dependent Variable LNY

Minimum tolerance for entry into model $=0.000000$

Backward stepwise with Alpha-to-Enter $=0.050$ and Alpha-to-Remove $=0.050$

Step \# $1 \mathrm{R}=0.358 \mathrm{R}$-Square $=0.128$

Term removed: $\mathrm{S}$

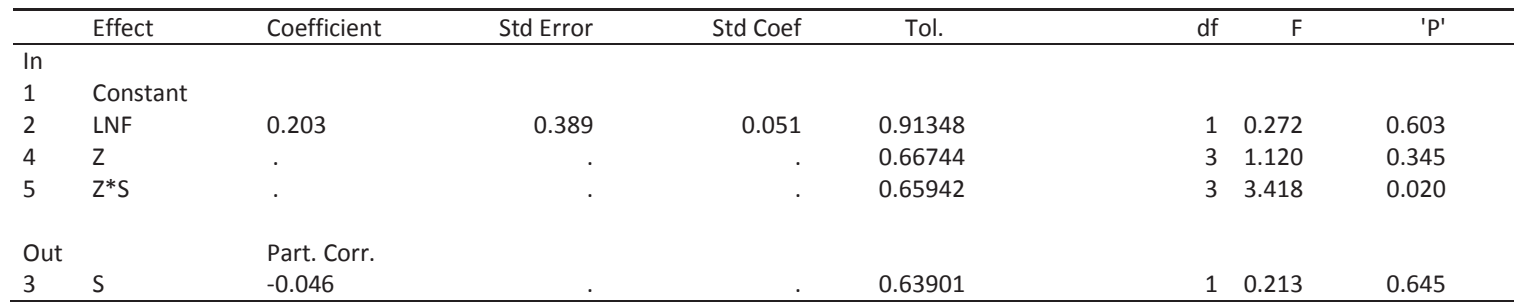

Step \# $2 \mathrm{R}=0.354$ R-Square $=0.126$

Term removed: LNF

\begin{tabular}{|c|c|c|c|c|c|c|c|c|}
\hline & Effect & Coefficient & Std Error & Std Coef & Tol. & $\mathrm{df}$ & $F$ & 'P' \\
\hline \multicolumn{9}{|l|}{ In } \\
\hline 1 & Constant & & & & & & & \\
\hline 4 & Z & . & . & . & 0.66757 & 3 & 1.235 & 0.301 \\
\hline 5 & $\mathrm{Z} * \mathrm{~S}$ & . & . & . & 0.66099 & 3 & 3.354 & 0.022 \\
\hline Out & & Part. Corr. & & & & & & \\
\hline 2 & LNF & 0.052 & . & . & 0.91348 & 1 & 0.272 & 0.603 \\
\hline 3 & $\mathrm{~S}$ & -0.044 & . & . & 0.64068 & 1 & 0.190 & 0.664 \\
\hline
\end{tabular}




\begin{tabular}{|c|c|c|c|c|c|c|c|c|}
\hline & Effect & Coefficient & Std Error & Std Coef & Tol. & $\mathrm{df}$ & $\mathrm{F}$ & 'P' \\
\hline 5 & $Z * S$ & . & . & . & 0.88914 & 3 & 3.578 & 0.016 \\
\hline Out & & Part. Corr. & & & & & & \\
\hline 2 & LNF & 0.075 & . & . & 0.98175 & 1 & 0.588 & 0.445 \\
\hline 3 & $S$ & 0.004 & . & . & 0.71226 & 1 & 0.002 & 0.964 \\
\hline
\end{tabular}

Após a retirada da covariável Inf, a análise que melhor explicou o efeito das variáveis independentes foi uma ANOVA. O resultado desta análise indicou os efeitos das estações do ano associadas às zonas da represa sobre a captura (interação $S * Z$ ). Para o modelo final foi feita uma análise de resíduos. Na Figura 28 observa-se o histograma dos resíduos do modelo final. O teste de Lilliefors $(p=0,278)$ para verificação da normalidade mostrou que os dados das variáveis estudadas apresentaram distribuição normal, validando o modelo.

O estudo de comparação entre os pares de médias para a interação estação do ano e zona da represa mostrou haver diferença estatística apenas na zona fluvial/braço Piracicaba em relação às estações do ano (Tabela 18$)$.

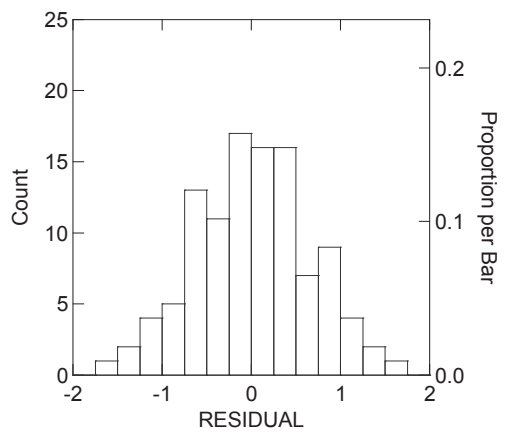

Figura 28: Histograma dos resíduos do modelo final da ANCOVA $\ln y=\mu+S^{*} Z+\varepsilon$ para os dados agrupados das pescarias artesanais de Barra Bonita, onde $S^{*} Z$ é a interação entre (S) estações do ano (dry=seca, rainy=chuvosa) e $(Z)$ zonas da represa $(\mathrm{RP}=$ zona fluvial/braço Piracicaba, $\mathrm{RT}=$ zona fluvial/braço Tietê, TRANS= zona de transição e LAKE= zona lacustre) e $\varepsilon$ é o erro experimental 
Tabela 18 Teste a posteriori entre as médias de Iny (logaritmo neperiano da captura, em $\mathrm{kg}$ ) obtidas a partir do modelo final $\ln c w=\mu+Z * S+\varepsilon$. Comparação entre as zonas da represa (LAKE= zona lacustre; RP= zona fluvial/braço Piracicaba; RT= zona fluvial/braço Tietê; TRANS= zona da transição) em relação às estações do ano (seca e chuvosa). Os números entre parêntesis representam os antilogaritmos das médias ajustadas, em escala aritmética.

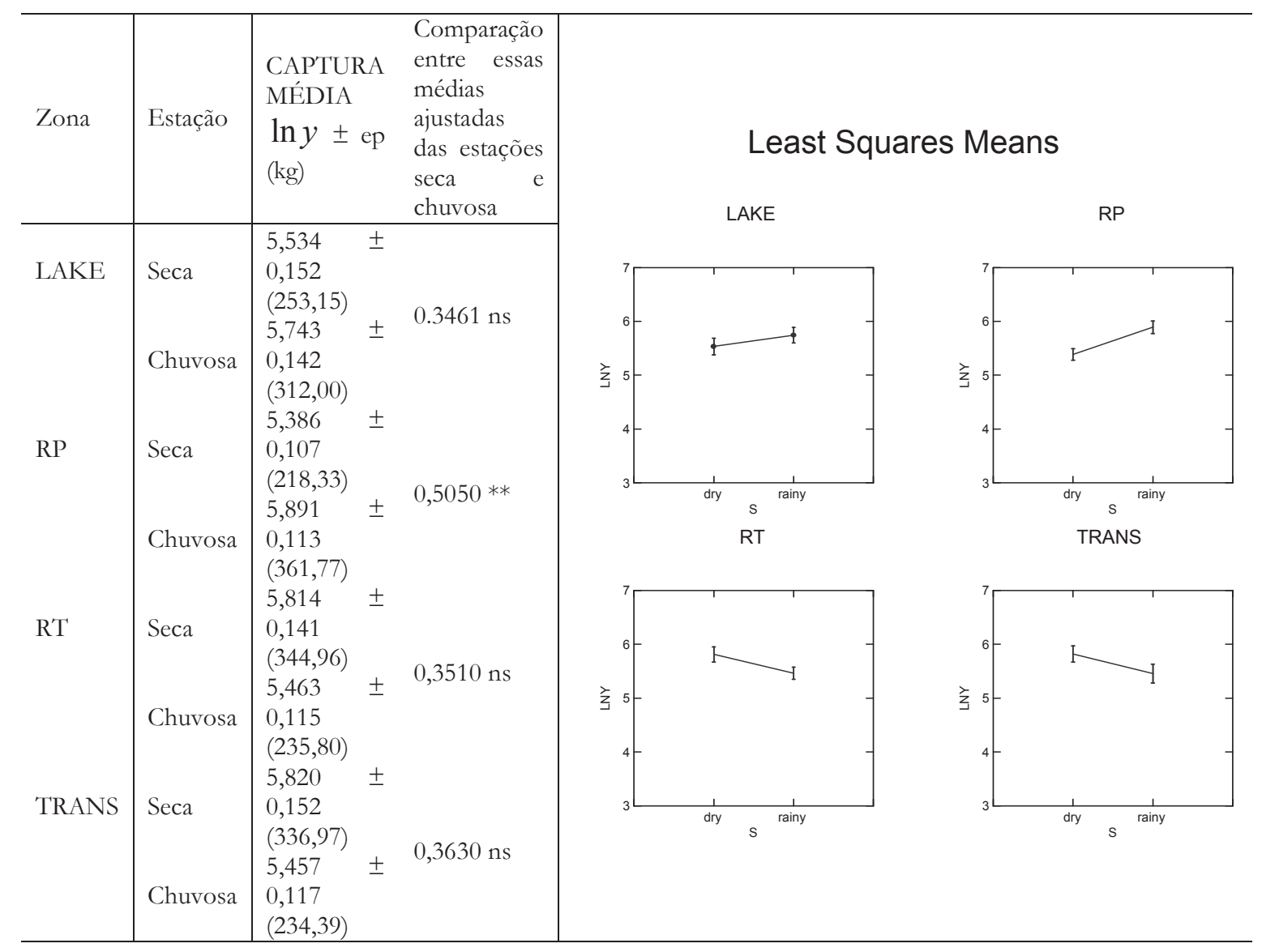

\subsection{DISCUSSÃO}

\subsubsection{Petrechos e embarcações}

Os estudos sobre os fatores envolvidos nas pescarias artesanais são importantes para se compreender as variações nas produções pesqueiras, seja entre pescadores da mesma represa, seja entre as diferentes zonas da represa. Além de fatores como arte e petrechos de pesca, tipo de embarcação, outros devem ser considerados, como a experiência do pescador, o local onde pesca, as oscilações provocadas pelas variações no clima, por exemplo (Agostinho et al., 2004).

A análise da experiência absoluta na atividade pesqueira (número de anos que o pescador pratica a atividade pesqueira) indicou que os pescadores mais tradicionais foram 
entrevistados na zona lacustre, durante a estação seca, apesar da comunidade pesqueira mais tradicional se encontrar na zona fluvial/braço Piracicaba, no bairro Tanquã (Venturato \& Valêncio, 2008). Estudos na represa Billings apontam diferentes tempos de experiência, com registros de menos de 15 anos (Minte Vera, 1997), 17,8 anos (Petrere et al, 2006) e 13 \pm 9 anos (Silva, 2009) e os entrevistados por Maruyama (2007) na região do Médio Tietê, menos de 10 anos. Camargo \& Petrere (2001) observaram pescadores com tempo de experiência superior (entre 28 e 30 anos) na região do Médio São Francisco (MG), com exercício predominante de suas atividades apenas na Bacia do Rio São Francisco. Os pescadores do Lago Paranoá (DF) entrevistados por Walter (2000) tinham em média 22 anos de experiência como pescador.

Os pescadores entrevistados afirmaram não haver territorialidade nas pescarias de Barra Bonita, embora Futemma \& Seixas (2008) tenham mencionado este fator em corpos de água fechados como lagos, represas e várzeas. A adoção de locais fixos para exploração do recurso pesqueiro pode não ocorrer na represa de Barra Bonita porque, conforme observaram Castro \& Begossi (1995) nas pescarias do Rio Grande, o exercício da territorialidade pode também ser pautado na dimensão temporal, com os pontos de pesca determinados segundo critérios de hereditariedade, por laços de parentesco ou amizade. Assim sendo, os pescadores da represa de Barra Bonita, por exercerem suas pescarias há pouco tempo no local (menos de 10 anos) podem ainda não utilizar esta prática como forma de manejo comunitário das pescarias. A territorialidade em águas interiores foi mais observadas em pescarias amadoras, como registrado por Peixer (2008).

A exemplo de pescadores atuantes ao longo dos trechos Médio e Alto Tietê (Maruyama, 2007), os pescadores de Barra Bonita também exerciam suas pescarias preferencialmente em embarcações próprias, de alumínio. Esta situação também foi descrita por Ceregato (2001) para o Complexo de Urubupungá e Castro (1992) no Rio Grande.

Embora tenha havido menções ao uso de mais de um petrecho de pesca, os pescadores forneceram informações detalhadas apenas sobre a rede de espera. Esta arte de pesca também foi predominante no Complexo de Urubupungá e Ceregato (2000) vê esta arte associada às áreas lênticas criadas a partir da construção de represas e à captura de peixes que não formam cardumes, em contraste com o uso de tarrafas, espinhéis em áreas lóticas e à captura de peixes em formação de cardumes (Castro, 1992). Apesar de ilegal, o uso de redes com abertura de malha inferior a $70 \mathrm{~mm}$ (entre nós opostos) é prática comum 
entre os pescadores e se destina à captura de lambaris e mandis de menor tamanho, como relatou Maruyama (2007).

A propriedade das embarcações e dos petrechos de pesca era de patrões/peixeiros e esta prática, segundo os cinco pescadores que a reportaram, mantinha suas produções atreladas aos proprietários, ou seja, os peixes capturados eram comercializados apenas com estes. Sautchuk (2008) descreveu situação semelhante nas pescarias amazônicas caracterizando (a) o aviador ou patrão, que fornece os produtos necessários à produção e à subsistência do pescador e (b) o aviamento, que implica na entrega da produção pesqueira completa ao patrão; este nunca recebe a dívida em dinheiro ou outro item, apenas em produtos da pesca. O patrão, além de ofertar crédito e receber a remessa, pode exercer a propriedade dos meios de produção (barcos e petrechos), comercializar mercadorias diversas (além da despesa fornecida aos aviados) e intermediar a venda da produção em centros maiores da região.

\subsubsection{Captura e esforço}

A menção à captura de 14 espécies de peixes representa 20,6\% das espécies que constituem a ictiofauna da represa de Barra Bonita (total de espécies levantado por Petesse, 2006). Das 22 espécies capturadas, 63,6\% eram Characiformes, 18,2\% eram Siluroformes e igual quantidade, Perciformes. A família com maiores capturas foi a Characidae, com 10 espécies. Dentre as espécies capturadas, houve menção às alóctones $S$. jurupari, $P$. squamosissimus (Bacia Amazônica), M. maculatus, L. anisitsi (outras bacias) e à exótica $O$. niloticus (africana) (Smith et al.,2002). Petesse (2006) observou que a maioria das introduções foi realizada pela CESP (Companhia Energética Estado de São Paulo) a fim de elevar a produção pesqueira da represa e compensar as alterações ambientais provocadas pela barragem do rio Tietê. Enquanto no Brasil as introduções são realizadas para aumentar a produção pesqueira de reservatórios, na Europa as introduções de espécies exóticas e alóctones são motivadas pelos motivos descritos por Holčík (1991) (Tabela 19). O sucesso do manejo dos recursos pesqueiros depende dos padrões de distribuição espacial e temporal dos peixes e dos pescadores (Pet \& Piet, 1993). 
Tabela 19: Motivos para introduções de espécies de peixes exóticas e alóctones (Fonte: Holčík (1991).

\begin{tabular}{l|l}
\hline Espécies exóticas & Espécies alóctones \\
\hline Aqüicultura, incluindo experimental $(30,6 \%)$ & Melhora do estoque selvagem $(37,6 \%)$ \\
Acidente $(21,0 \%)$ & Razões desconhecidas $(20,8 \%)$ \\
Razões desconhecidas $(15,5 \%)$ & Acidente $(18,4 \%)$ \\
Aumento do estoque pesqueiro $(14,7)$ & Esporte $(12,0 \%)$ \\
Biomanipulação $(7,1)$ & Aqüicultura $(7,2)$ \\
Ornamentação $(11,1)$ & Ornamentação $(4,0 \%)$ \\
\hline
\end{tabular}

O sucesso das pescarias, traduzido pela captura média diária, foi maior na zona fluvial/braço Piracicaba, durante a estação chuvosa. Apesar disso, o maior esforço pesqueiro médio diário foi registrado na zona de transição, estação chuvosa. Este fator mostra que, neste caso, as capturas podem depender muito mais do local e estação do ano do que do próprio esforço pesqueiro exercido. Na região e estação do ano onde houve as maiores capturas foram registradas também quase todas as espécies apontadas pelos pescadores e a diversidade de ecótonos pode ter favorecido esta distribuição (Marinelli, 2002). Os aspectos quantitativos e qualitativos podem ser explicados:

(a) Pela complexidade do ambiente, uma vez que a zona litoral braço do Rio Piracicaba possui margens meandrantes e bancos formados pelo assoreamento que proporcionam ambientes diversificados, aumento da zona litoral e, consequentemente, aumento das zonas de refúgios e da oferta de alimentos (Smith et al, 2003). Os padrões de riqueza e diversidade também variam de acordo com o tipo de ambiente, e as maiores diversidades e riquezas são encontradas em sua zona litorânea, o que ressalta a importância dessas áreas para a manutenção da diversidade ictiofaunística (Agostinho et al., 1997);

(b) Pela presença de macrófitas que colaboram para o enriquecimento de corpos d'água, e consequentemente, para o aumento de oferta de alimento natural (Thomaz, 2002). Esta vegetação, seja enraizada ou flutuante, também agrega a comunidade aquática e serve com área de refúgio.

Houve discrepância entre os registros das capturas diária e semanal e esta pode ser atribuída à dificuldade do pescador em manter registros de suas capturas, dada a baixa escolaridade (Capítulo 1). A observação da captura e do esforço semanal (maiores registros de ambos na zona de transição, estação seca) leva a crer que, nesta situação, o sucesso das capturas esteve ligado: 
(a) Às características fisiográficas da área, em que se encontra a llha do Cerrito e que recebe as águas dos Rios Araquá, Ribeirão do Onça, conferindo características semelhantes às encontradas nas áreas fluviais (regiões meandrantes, maior oferta de alimento e zonas de refúgio);

(b) À redução da lâmina d'água provocando a criação de novos habitats e mudanças nas variáveis limnológicas;

(c) Ao pequeno deslocamento para as pescarias devido à pequena autonomia pesqueira das embarcações;

(d) Ao próprio esforço pesqueiro, mais elevado nas outras zonas/estações, proporcionando maiores capturas.

Considerando a área da represa de Barra Bonita (31000 ha) e a produção pesqueira para o período de estudo (37198 $\mathrm{kg}$ ) a produtividade pesqueira seria de 1,20kg/ha/ano. Uma vez que foram entrevistados 103 pescadores, perfazendo 25,6\% dos pescadores estimados na represa de Barra Bonita, a produção pesqueira real seria em torno de $30,7 \mathrm{~kg} / \mathrm{ha} / \mathrm{ano}$. Esta produção estaria próxima à encontrada por Maruyama (2007) para as represas do Médio Tietê e superior aos valores calculados para a região do Complexo de Urubupungá (Ceregato, 2001; dados compilados por Petrere et al, 2002; Agostinho et al, 2007). Comparando às represas do Rio Tietê e da região do Alto Paraná, as produções dos açudes da Região Nordeste do Brasil (Paiva et al, 1994) e das pequenas represas africanas e indianas (dados compilados por Jackson \& Marulla, 2001) tem produção elevada (Tabela 20).

Petrere (1996) destacou três razões para justificar as baixas produtividades pesqueiras das represas brasileiras, das quais duas podem ser aplicadas a este estudo:

(i) Baixa intensidade de pesca comparada à intensidade registrada nos açudes do Nordeste do Brasil e a lagos africanos. As baixas densidades de pescadores das represas do Rio Tietê, e particularmente de Barra Bonita podem ser justificadas pelas constantes mudanças dos pescadores, de represa em represa, em busca de maiores capturas (Capítulo 2);

(ii) Deficiência nos repovoamentos promovidos pelas autoridades competentes, com estocagem de espécies cujo sucesso e adaptação ao ambiente são comprometidos. Petesse (2006) observou que algumas das espécies de peixes introduzidas pela CESP (Companhia Energética Estado de São Paulo) na década de 1970 não aparecem nas 
pescarias profissionais ou experimentais desde 1989, indicando provável insucesso do processo de adaptação.

Tabela 20: Comparação entre a intensidade de pesca em Barra Bonita, outras represas do Rio Tietê, represas do Brasil e de outras regiões tropicais

\begin{tabular}{|c|c|c|c|c|}
\hline \multicolumn{2}{|l|}{ Rio/Represa } & Autor & $\begin{array}{l}\text { Intensidade de } \\
\text { pesca }\left(\text { pesc } / \mathrm{km}^{2}\right)\end{array}$ & $\begin{array}{ll}\text { Produção } & \text { pesqueira } \\
\text { (kg/ha/ano) } & \end{array}$ \\
\hline \multirow{5}{*}{ Rio Tietê } & \multirow{3}{*}{ Barra Bonita } & Petrere et al (2002) & 0,23 & 6,0 \\
\hline & & Maruyama (2007) - 2003/04 & 1,18 & 39,4 \\
\hline & & Presente estudo & 1,30 & 30,7 \\
\hline & \multirow{2}{*}{ Billings } & Minte-Vera (1997) & 0,9 & 63,0 \\
\hline & & Silva (2008) & 1,0 & 16,2 \\
\hline \multirow{3}{*}{$\begin{array}{l}\text { Rio Tietê e } \\
\text { Alto } \quad \text { Rio } \\
\text { Paraná }\end{array}$} & $\begin{array}{l}\text { Complexo de } \\
\text { Urubupungá } \\
\text { Jupiá+Ilha } \\
\text { Solteira }\end{array}$ & $\begin{array}{l}\text { Valor calculado a partir dos } \\
\text { dados de Ceregato (2001) }\end{array}$ & 0,33 & 0,18 \\
\hline & Jupíá & Petrere et al (2002) & 0,14 & 4,7 \\
\hline & Ilha Solteira & $\begin{array}{ll}\text { Dados compilados } & \text { por } \\
\text { Agostinho et al (2007) } & \end{array}$ & - & $\begin{array}{l}0,80(1996) \\
1,10(2000)\end{array}$ \\
\hline \multicolumn{2}{|c|}{ Açudes da região Nordeste } & Paiva et al (1994) & - & $18-667$ \\
\hline \multirow{5}{*}{$\begin{array}{l}\text { Reservatórios } \\
\text { Tropicais }\end{array}$} & $\begin{array}{l}\text { Chenderoh } \\
\text { Reservoir, } \\
\text { Malásia }\end{array}$ & Kah-Wai \& Ali (2001) & 15 pescadores & 6,76 \\
\hline & $\begin{array}{l}\text { Reservatórios } \\
\text { Indianos }\end{array}$ & $\begin{array}{l}\text { Dados compilados por De } \\
\text { Silva (1996) }\end{array}$ & - & 20,1 \\
\hline & Sri Lanka & Pet et al (1995) & - & $150-250$ \\
\hline & $\begin{array}{l}\text { Reservatórios } \\
\text { africanos }\end{array}$ & $\begin{array}{l}\text { Dados compilados por } \\
\text { Jackson \& Marmulla (2001) }\end{array}$ & - & $\begin{array}{l}\text { Pequenos: } 329 \\
\text { Médios: } 80-90 \\
\text { Grandes: } 27-65\end{array}$ \\
\hline & $\begin{array}{l}\text { Reservatórios } \\
\text { Indianos }\end{array}$ & $\begin{array}{l}\text { Dados compilados por } \\
\text { Jackson \& Marmulla (2001) }\end{array}$ & - & $\begin{array}{l}\text { Pequenos: 49,5 } \\
\text { Médios: } 12,3 \\
\text { Grandes: } 11,4\end{array}$ \\
\hline
\end{tabular}

A baixa produtividade pode também ser justificada pelas dimensões da represa de Barra Bonita. Jackson \& Marmulla (2001) observaram que pequenos reservatórios africanos e indianos tinham maior produção pesqueira do que os de maior dimensão e atribuíram este fato à maior produtividade primária dos reservatórios menores.

A espécie com maior captura foi a tilápia, presente em todas as zonas e em ambas estações de estudo, perfazendo $71,1 \%$ da captura total. Tal informação corrobora as pesquisas de Maruyma (2007) na região do Médio Tietê, onde também foram observadas elevadas capturas desta espécie (88,9\%). Esta espécie ainda teve participação nas pescarias estudadas por Minte-Vera (1997) na represa Billings (SP); no Médio Rio Doce (MG) (Latini, 2005); nas pescarias artesanais do Lago Paranoá (DF) (Walter, 2000); nos açudes pernambucanos (Paiva et al, 1994), na bacia do Rio Paraná (Agostinho et al., 1997), além dos perigos do escape de tanques de piscicultura na região Norte (Gama \& Halboth, 2004). O 
sucesso da dispersão/adaptação desta espécie, e consequentemente de suas elevadas capturas em pescarias artesanais, se deve (a) ao cuidado com a prole; (b) à dieta onívora, não demonstrando especialização em itens específicos; (c) ao interesse comercial de sua criação para fins ornamentais ou alimentares (Latini, op.cit.).

Na região fluvial/braço Piracicaba foi capturado o maior número de espécies e este incremento também foi observado por Petesse (2006) ao comparar as capturas os braços da represa de Barra Bonita.

\subsection{3. Índice de captura e análise estatística}

A cpue é um índice ser amplamente utilizado para expressar produção em função do esforço pesqueiros (Petrere et al, 2010) e neste estudo isto não aconteceu, pois as análises indicaram que a regressão testada não foi linear e não passou pela origem, e portanto, o estudo de cpue seria um índice viciado de abundância.

A ANCOVA foi adotada, portanto, por não ser uma análise influenciada pela intercepção da reta de origem, podendo o sucesso das capturas ser influenciado por fatores como a sazonalidade e o local de pescaria, por exemplo.

Os fatores ano, área, sua interação e a covariável esforço de pesca foram significativos e determinaram o sucesso das capturas das pescarias comerciais do reservatório de Itaipu (Okada et al, 1996). As pescarias dos açudes do Nordeste foram determinadas pelo fator número de espécies de predadores no açude e pelas covariáveis área do açude, profundidade e número de pescadores registrados (Paiva et al, 1994). Neste estudo, o esforço de pesca não foi significativo no sucesso das pescarias, estando este atrelado aos fatores ambientais e fisiográficos da represa de Barra Bonita. A detecção da interação entre a sazonalidade e da estação do ano como fatores determinantes da produção pesqueira indica que, além dos fatores relacionados à zona fluvial do braço do Rio Piracicaba já discutidos anteriormente, a pluviosidade interfere diretamente, elevando as capturas no local. Petesse (2006) também identificou os fatores ambientais e sazonais como determinantes das cpues calculadas e seu estudo também apontou incremento nas capturas para as zonas lacustre e fluvial/braço Piracicaba. As diferenças entre as estações do ano para as quantidades de peixes capturados poderiam ser provocadas por migrações provocadas pelas mudanças nas variáveis limnológicas (Petesse, op.cit.). 


\section{CAPÍTULO 4}

\section{ESTUDO ECONÔMICO DAS PESCARIAS ARTESANAIS DE BARRA BONITA}

\subsection{CONSIDERAÇÕES INICIAIS}

As pescarias artesanais tradicionais se caracterizam por envolverem os familiares dos pescadores, ocorrerem com o emprego de pequeno capital e energia, em embarcações de pequeno porte, com pequeno esforço pesqueiro, em termos de deslocamento para a captura (viagens curtas próximas aos locais de embarque/desembarque do pescado) (FAO, 2008).

A ligação entre investimento, manejo, processamento, distribuição e consumo - a cadeia produtiva - é essencial para a determinação do papel do pescador artesanal e demonstra o amplo espectro de atividades e pessoas envolvidas no processo. As tecnologias envolvidas nas pescarias artesanais são simples, tornando a atividade pesqueira e sua cadeia produtiva acessíveis a pessoas que disponham de recursos limitados para investimento. Apesar disso a cadeia produtiva das pescarias artesanais não se limita às conexões e mercados tradicionais e fazem parte de um importante setor cada vez mais dinâmico e competitivo (FAO, 2008).

A Organização para a Cooperação e Desenvolvimento Econômico (Organization for Économic Co-operation and Development, OECD), organização internacional que reúne 30 
países e é voltada à coordenação de políticas econômicas nacionas e internacionais, define bioeconomia como parte das atividades econômicas que capturam valor a partir de processos biológicos e biorrecursos para produzir saúde, crescimento e desenvolvimento sustentável. Barros e Machado-Neto (2008) ressaltam que apenas os 30 países membros da OECD e alguns em desenvolvimento tiveram participação relevante na corrida bioeconômica. No Brasil não é freqüente ainda o emprego do termo bioeconomia nos documentos oficiais relacionados à política industrial e de comércio exterior e os autores sugerem que país deveria estabelecer um projeto de bioeconomia cujas metas seriam: (a) analisar os gargalos e obstáculos ao desenvolvimento dessa área de conhecimento e (b) colher e analisar informações para orientar os formuladores de políticas, a exemplo dos países-membros.

Na América Latina não existe um reconhecimento do valor das pescarias de pequena escala, nem compreensão da contribuição econômica e social desta atividade. Além disso, os recursos pesqueiros encontram-se em declínio e a demanda pelo pescado, em ascensão (FAO, 2006). De acordo com Beltrán Turriago (2001), em países da América Central e do Sul, os pescadores artesanais tem níveis econômico e educacional baixos, aprendem o ofício por tradição da família e participam da pesca desde a sua juventude, o que significa que muitos deles abandonam a escola para ajudar no sustento de suas famílias.

\subsection{ESTUDOS BIOECONÔMICOS NO BRASIL}

No Brasil os estudos sobre as condições sócio-econômicas dos pescadores são voltados para pescadores artesanais (Okada et al., 1997; Mendonça, 1999; Camargo, 1998; Minte-Vera, 1997; Walter, 2000; Ceregato \& Petrere, 2003, Petrere et al, 2006). O conhecimento sobre as pescarias artesanais é ainda objeto de estudos sobre ecologia humana (Costa-Neto et al., 2002; Madi, 1998; Carvalho, 2002a, 2002b, Begossi \& Garavelo, 1990; Begossi \& Braga, 1992).

Abordagens econômicas das atividades pesqueiras em água doce foram realizadas por Okada et al (1997) nos reservatórios de Salto Santiago e Quedas do Iguaçu (PR) e os autores concluíram que, apesar do baixo rendimento, as pescarias artesanais nesta região são de fundamental importância para o sustento familiar deste segmento da sociedade. 
As pescarias artesanais do Rio São Francisco (MG) foram estudadas por Camargo e Petrere (2001) e os custos variáveis estiveram diretamente ligados à captura, e conseqüentemente à renda.

Ceregato (2001) estudou os aspectos econômicos das pescarias artesanais realizadas no Complexo de Urubupungá (SP), cujos rendimentos foram de $\mathrm{R} \$ 13,19$ e $\mathrm{R} \$ 19,54$ para os reservatórios de Ilha Solteira e Jupiá, respectivamente. A autora determinou também qual o modelo explicava a variável-resposta lucro das pescarias e concluiu que os fatores educação, aparelhos de pesca e a covariável número de dias que pesca foram significativos.

A avaliação da renda dos pescadores da represa Billings (SP) foi realizada por Petrere et al (2006) e o retorno econômico diário era de $\mathrm{R} \$ 15,75$, cuja pesca era sustentada principalmente pela captura de tilápias com o uso de rede de espera.

Frossard (2003) fez uma abordagem econômica sobre as pescarias artesanais marinhas cearenses através do método de Custeio Baseado em Atividades ( $A B C$, ActivityBased Costing) e comparou resultados obtidos a outros decorrentes do método de Custeio por Absorção. Este é baseado no volume de produção de uma empresa, ou seja, o esforço de fabricação é medido em termos de custos absorvidos pela produção dos bens. O moderno método de custeio $A B C$ considera os custos decorrentes das atividades da empresa, e não do volume de bens produzidos.

Os aspectos econômicos das pescarias de Manaus (AM) foram estudados por Cardoso et al (2004) e as embarcações pequenas apresentaram custo operacional médio por expedição de $45,2 \%$ da renda bruta da venda do pescado, enquanto as embarcações médias e grandes apresentaram valores de $42,0 \%$ e $47,8 \%$ dos custos, respectivamente.

Mattos (2004) aplicou um modelo bioeconômico desenvolvido para as pescarias do Mar Mediterrâneo (Mediterranean Fisheries Simulation oools - MEFISTO - Ferramentas de Simulação de Pescarias Mediterrâneas) às pescarias artesanais marinhas de Pernambuco e concluiu que as pescarias de linha-de-mão (pargueira) e de rede-de-espera alcançaram equilíbrio, tanto econômico quanto biológico.

Cardoso \& Freitas (2006) estudaram as características econômicas da frota pesqueira sediada na região do Médio Rio Madeira (AM) e concluíram que a maior parcela dos custos era referente à aquisição de apetrechos. Os autores consideraram a frota dividida em dois grupos (a) barcos, com o combustível sendo o principal item dos custos e (b) canoas, tendo como principais itens dos custos o combustível e gelo. Vale ressaltar que os autores 
desconsideraram o desgaste do uso dos petrechos, superestimando os lucros provenientes da operação de pesca.

As pescarias de pequena escala da planície de inundação do Alto Rio Paraná (PR) foram estudadas por Carvalho (2008), cujas rendas foram obtidas a partir de informações com os pescadores profissionais. A autora identificou os itens "custos com a embarcação" e "consumo do pescado pela família" como os que mais contribuem com a formação da renda, apesar da atividade não ser rentável. Além disso, o controle das inundações determina as oscilações das capturas, e consequentemente os custos e lucros das operações pesqueiras.

\subsection{OBJETIVOS}

- Comparar os aspectos econômicos das pescarias profissionais de pequena escala entre as zonas fluvial (braços dos rios Piracicaba e Tietê), transição e lacustre do reservatório de Barra Bonita;

- Avaliar o rendimento econômico da atividade pesqueira, com base nos custos e na receita obtida a partir da comercialização do pescado;

- Testar diferentes métodos de análise bioeconômica das pescarias artesanais de Barra Bonita.

\subsection{METODOLOGIA}

\subsubsection{Cálculo dos custos}

Os custos fixos incluem a depreciação da embarcação e dos petrechos de pesca. Eles não variam de acordo com a atividade pesqueira (Hanesson, 1993), dependem das características da frota e podem variar entre embarcações de uma mesma frota. Os valores referentes aos custos, receita e lucro foram obtidos conforme proposto por Agostinho et al. (1994) e Okada et al. (1997) (Tabela 21). Apesar dos resultados destes valores serem usualmente expressos em anos ou em dias, optou-se por utilizá-los, para a aplicação dos testes estatísticos, em termos de semanas, porque esta foi a unidade de tempo para a qual os pescadores forneceram informações mais detalhadas de suas capturas 
Os custos dos pescadores foram divididos em dois componentes:

1. Custos fixos: gastos com manutenção e depreciação da embarcação. Nestes foram incluídos os custo de aquisição, manutenção e depreciação do motor devido à dificuldade dos pescadores em estimar tais custos separadamente.

2. Custos variáveis: consumo de combustível, forma de conservação do pescado e remuneração do ajudante.

O cálculo da receita foi obtido a partir do volume de pescado capturado $(\mathrm{kg})$ por espécie, o preço médio de comercialização do quilo do pescado por espécie.

O lucro foi obtido subtraindo-se a receita dos custos.

Tabela 21 Equações utilizadas para os cálculos de custos, receita e lucro.

\begin{tabular}{|c|c|c|}
\hline $\begin{array}{l}\text { Custo fixo unitário do } \\
\text { aparelho de pesca }(C f a)\end{array}$ & $C f a=D a+M a$ & $\begin{array}{l}D a: \text { depreciação do aparelho de pesca, dada por } \\
D a=P a / t a \text { (Pa é o preço unitário do aparelho, ta é o } \\
\text { tempo útil de vida do aparelho) } \\
\text { Ma: custo de manutenção do aparelho. }\end{array}$ \\
\hline $\begin{array}{l}\text { Custo fixo unitário da } \\
\text { embarcação e sistema de } \\
\text { impulsão }(C f e \imath)\end{array}$ & $C f e i=D e+M e$ & $\begin{array}{l}\text { De: depreciação da embarcação, dada por } D e=P e / \text { te } \\
\text { (Pe é o preço unitário da embarcação, te é o tempo útil de } \\
\text { vida da embarcação) } \\
\text { Me: custo de manutenção da embarcação }\end{array}$ \\
\hline Custo $(C v)$ & $C=C f a+C f e i+C v$ & $C v$ : custos variáveis \\
\hline Receita (R) & $R=\sum_{s} Q_{s} \times P s$ & $\begin{array}{l}\text { Qs: quantidade de pescado capturado }(\mathrm{kg}) \\
P_{s:} \text { preço médio de comercialização do quilo do pescado, } \\
\text { por espécie }\end{array}$ \\
\hline Lucro $(L)$ & \multicolumn{2}{|l|}{$L=R-C$} \\
\hline
\end{tabular}

\subsubsection{Análise estatística}

Aos dados das pescarias artesanais da represa de Barra Bonita foi aplicada uma Análise de Covariância (ANCOVA), pois esta se constitui numa importante ferramenta para a análise de dados pesqueiros por serem muitos os fatores que determinam o sucesso das operações de pesca (Petrere, 1986). Além disso, esta é uma ferramenta mais adequada que a ANOVA, pois possibilita a comparação de médias através de uma relação linear entre a variável dependente (lucro) e as covariáveis (idade do pescador, tempo experiência como pescador, dias de pesca durante a semana) sem dividir a captura pelas covaráveis, que é uma decisão válida somente se a reta passar pela origem, o que nem sempre ocorre (Huitema, 1980). Estudos têm sido desenvolvidos utilizando esta ferramenta para análise de dados sobre pescarias (Murray- Jones \& Steffe, 2000; Camargo \& Petrere, 2001; Pet et al, 1995; Okada et al, 1996). 
Para efeitos comparativos, a avaliação econômica da atividade pesqueira foi conduzida segundo a mesma metodologia utilizada por Ceregato (2001) e Minte-Vera (1997). Assim, o modelo completo testado inicialmente foi:

$$
\ln L=\mu+Z+S+E_{C}+\operatorname{In}+E+P+\ln I+\ln T+\ln f+\varepsilon
$$

\begin{tabular}{|c|c|c|}
\hline & & Onde \\
\hline Fatores & $\begin{array}{l}\text { Z } \\
\mathrm{S} \\
\mathrm{EC}\end{array}$ & 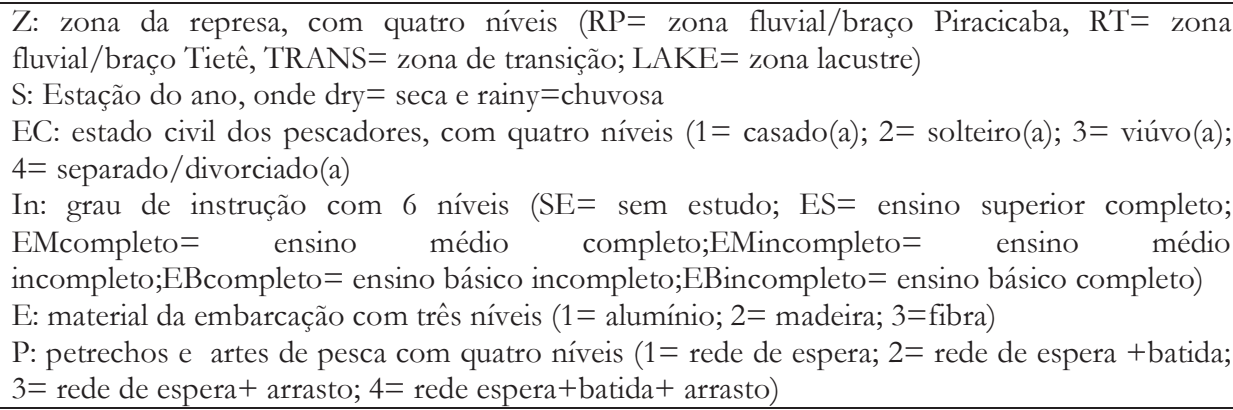 \\
\hline Covariáveis & $\begin{array}{l}\ln \mathrm{I} \\
\ln \mathrm{T} \\
\ln f\end{array}$ & $\begin{array}{l}\text { lnI: logaritimo da idade média dos pescadores, expressa em anos completos } \\
\text { ln'T: logaritimo do tempo de experiência como pescador, expressa em anos completos } \\
\text { lnf: logaritmo do número de dias que pesca durante a semana }\end{array}$ \\
\hline
\end{tabular}

Como foram identificados valores negativos para os lucros das pescarias, foram aplicadas duas transformações aos dados: (1) soma de 353 (valor do menor déficit financeiro ) às variáveis dependente (L: lucro) e independentes (I: idade; T: tempo de experiência; f: esforço) e (2) logaritmo da variável.

\begin{tabular}{l|l|l}
\hline Transformação & 1: Variável +353 & 2: Variável logaritmizada \\
\cline { 2 - 3 } & $\mathrm{L}_{\mathrm{t}}=\mathrm{L}+353$ & $\ln \mathrm{L}_{\mathrm{t}}$ \\
& $\mathrm{I}_{\mathrm{t}}=\mathrm{I}+353$ & $\ln \mathrm{I}_{\mathrm{t}}$ \\
& $\mathrm{T}_{\mathrm{t}}=\mathrm{T}+353$ & $\ln \mathrm{T}_{\mathrm{t}}$ \\
& $\mathrm{f}_{\mathrm{t}}=\mathrm{f}+353$ & $\ln \mathrm{f}_{\mathrm{t}:}$ \\
\hline
\end{tabular}

Os dados foram analisados com o programa SYSTAT 11 (SYSTAT, 2004, versão demo).

\subsection{RESULTADOS}

\subsubsection{Comercialização}

Os peixes capturados eram comercializados principalmente nos domicílios e nas embarcações dos pescadores (Figura 29A) e vendidos a peixeiros ou diretamente ao consumidor (Figura 29B). A principal forma de conservação/comercialização do pescado foi em gelo e os pescadores utilizavam mais de uma forma de conservação (Figura 30). 

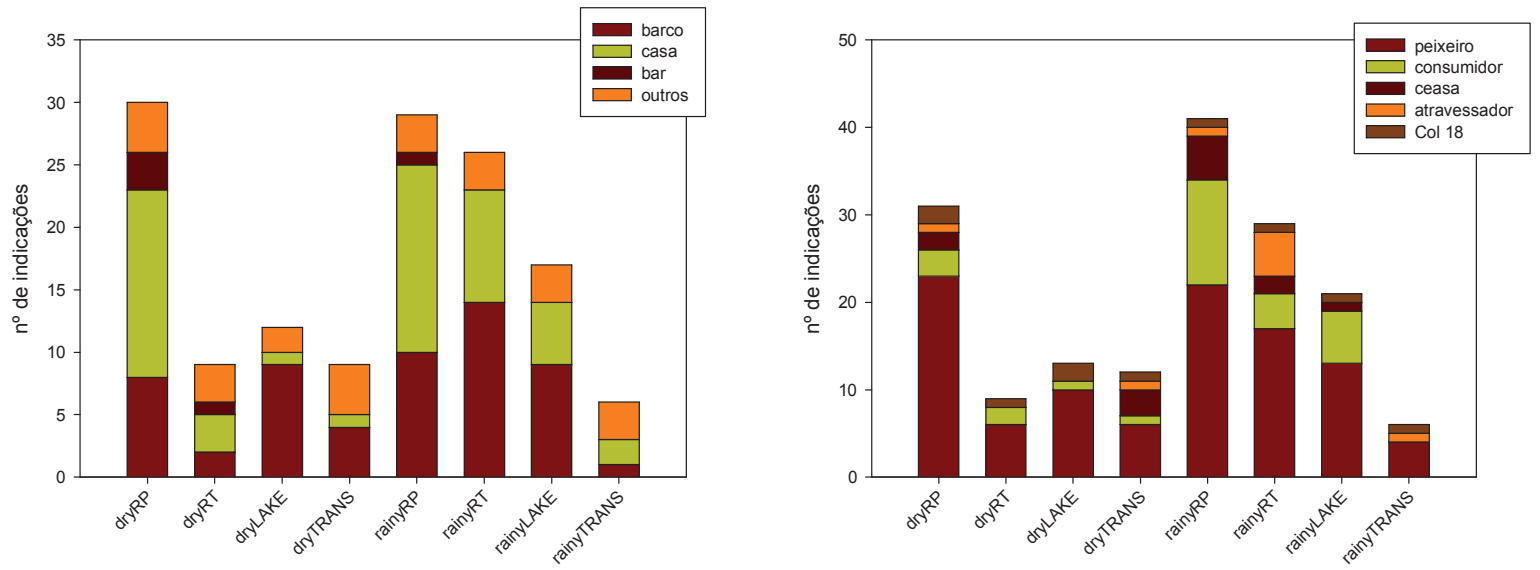

A

Figura 29: (a) Locais de comercialização e (b) principais compradores do pescado capturado pelos pescadores artesanais da represa de Barra Bonita, onde dryLAKE= estação seca, zona lacustre; dryRP= estação seca, zona fluvial/braço Piracicaba; dryRT= estação seca, zona fluvial/braço Tietê; dryTRANS= estação seca, zona de transição; rainyLAKE= estação chuvosa, zona lacustre; rainyRP= estação chuvosa, zona fluvial/braço Piracicaba; rainyRT= estação chuvosa, zona fluvial/braço Tietê; rainyTRANS= estação chuvosa, zona de transição.

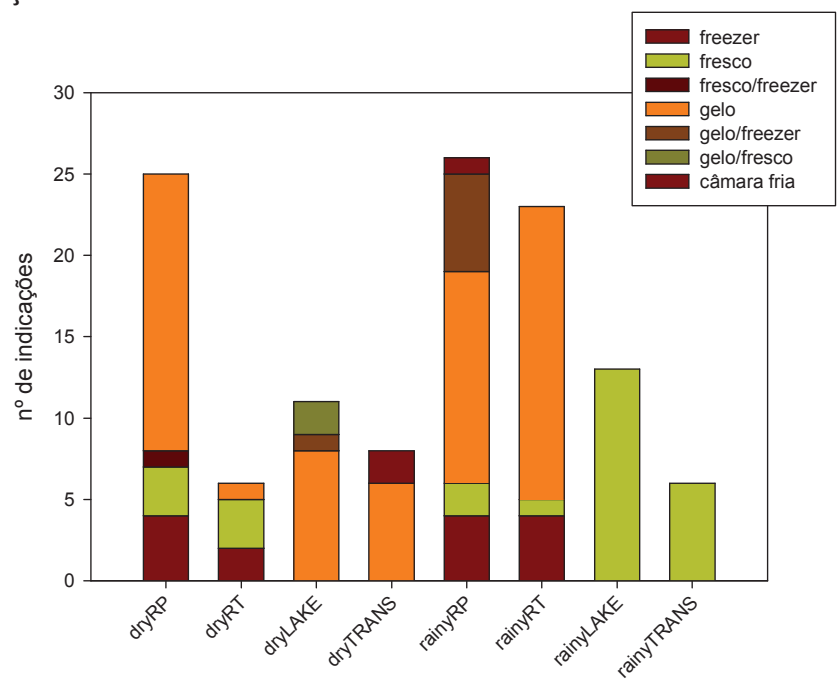

Figura 30: Formas de conservação do pescado da represa de Barra Bonita, onde dryLAKE= estação seca, zona lacustre; dryRP= estação seca, zona fluvial/braço Piracicaba; dryRT= estação seca, zona fluvial/braço Tietê; dryTRANS= estação seca, zona de transição; rainyLAKE= estação chuvosa, zona lacustre; rainyRP= estação chuvosa, zona fluvial/braço Piracicaba; rainyRT= estação chuvosa, zona fluvial/braço Tietê; rainyTRANS= estação chuvosa, zona de transição). 


\subsubsection{Custos fixos}

O estudo dos custos fixos indicou o maior valor médio de aquisição de embarcação $(\mathrm{Pe}=\mathrm{R} \$ 3.633,33)$ para pescadores entrevistados na estação seca, zona fluvial/braço Tietê, com tempo de vida útil de cerca de 6,7 anos, acarretando a depreciação anual de $\mathrm{R} \$ 595,00$, e custo anual da embarcação de $R \$ 958,33$. O maior tempo de vida útil (te=13,33 anos) foi registrado para pescador entrevistado na estação seca, zona lacustre, com custo médio de $\mathrm{R} \$ 2.391,67$, depreciação anual de $\mathrm{R} \$ 207,78$ e custo anual de $\mathrm{R} \$ 446,95$. O maior valor médio unitário de aquisição de petrechos $(R \$ 59,44)$ foi calculado para a estação seca, zona fluvial/braço Piracicaba, com vida útil estimada em 0,62 anos, depreciação anual de $\mathrm{R} \$$ 198,66 e custo fixo anual de $\mathrm{R} \$ 204,60$. O menor custo anual (R\$ 184,19) foi registrado na estação seca, zona lacustre, decorrente do menor valor médio unitário de petrecho $(\mathrm{Pa}=\mathrm{R} \$$ 51,33) e depreciação anual de $\mathrm{R} \$ 179,06$ (Tabela 22).

\subsubsection{Custos variáveis}

\subsubsection{Remuneração de ajudante, conservação de pescado e gasto com combustível}

Os custos variáveis foram expostos em termos de gastos com combustível e, eventualmente, gelo e gastos com parceiros. O maior e o menor custos médios com insumos foram registrados na zona de transição, nas estações chuvosa $(R \$ 262,00)$ e seca $(R \$ 88,75)$, respectivamente. $\mathrm{O}$ maior e o menor custos médios com parceiros foram registrados na estação chuvosa, nas zonas de transição $(R \$ 67,50)$ e lacustre $(R \$ 21,35)$, respectivamente (Tabela 23). 


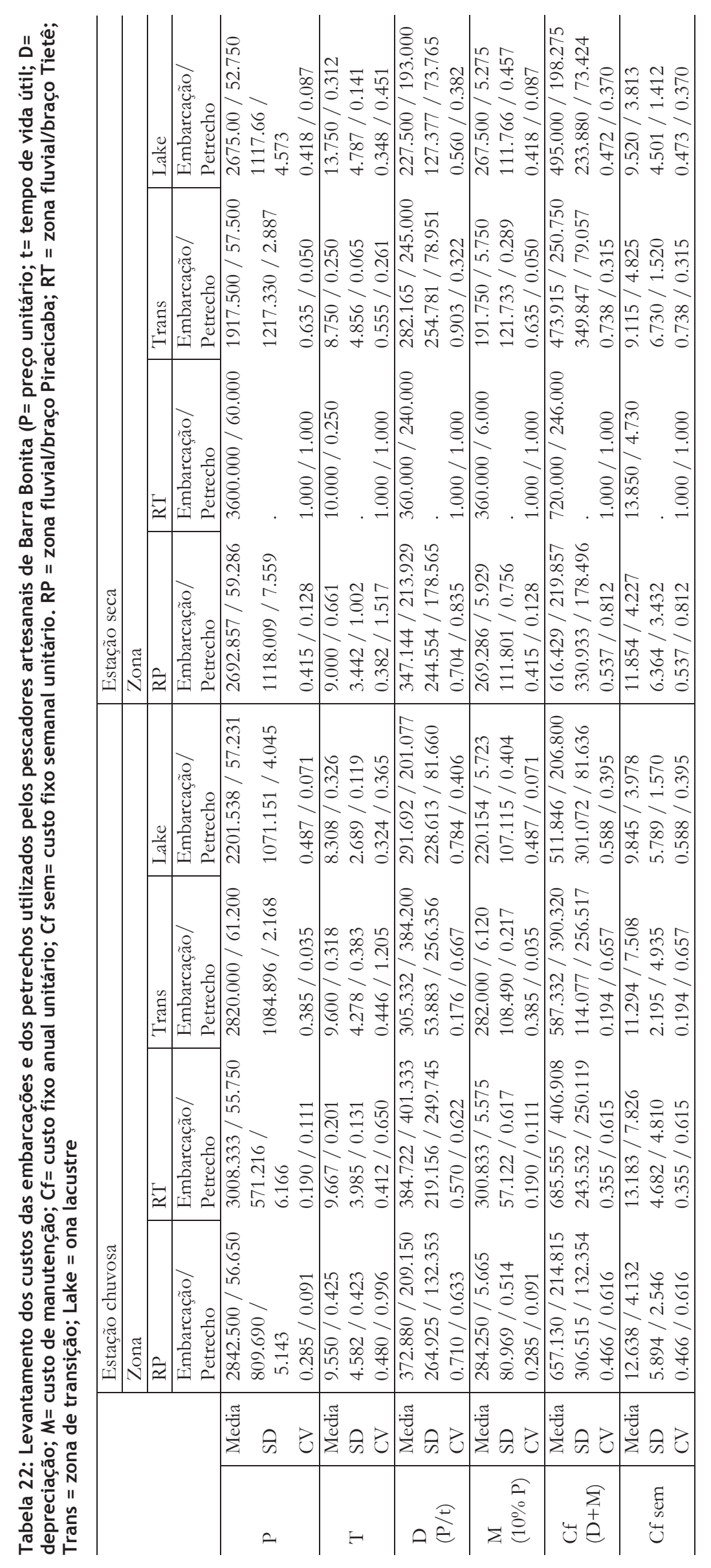


Tabela 23: Custos variáveis das pescarias artesanais de Barra Bonita (In=gasto com gasolina, óleo para motor; Parc= pagamento de parceiro/ajudante; $\mathrm{C}$ sem= soma dos Insumos+Parceiro, por semana. $\mathrm{RP}=$ zona fluvial/braço Piracicaba; RT = zona fluvial/braço Tietê; Trans = zona de transição; Lake = zona lacustre.

\begin{tabular}{|c|c|c|c|c|c|c|c|c|c|}
\hline & \multicolumn{4}{|c|}{ Estação chuvosa } & \multicolumn{4}{|c|}{ Estação seca } \\
\hline & & \multicolumn{4}{|c|}{ Zona } & \multicolumn{4}{|c|}{ Zona } \\
\hline & & RP & RT & Trans & Lake & $\mathrm{RP}$ & RT & Trans & Lake \\
\hline \multirow[b]{3}{*}{$\exists$} & Media & 168.750 & 234.167 & 262.000 & 123.846 & 115.000 & 90.000 & 88.750 & 90.000 \\
\hline & SD & 67.354 & 263.524 & 126.570 & 72.863 & 36.056 & . & 41.307 & 49.666 \\
\hline & $\mathrm{CV}$ & 0.399 & 1.125 & 0.483 & 0.588 & 0.314 & 1.000 & 0.465 & 0.552 \\
\hline \multirow{3}{*}{ 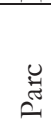 } & Media & 59.625 & 52.083 & 67.500 & 21.346 & 32.500 & 45.000 & 25.000 & 56.250 \\
\hline & SD & 110.308 & 70.274 & 113.743 & 37.033 & 57.979 & ${ }^{\circ}$ & 50.000 & 65.749 \\
\hline & $\mathrm{CV}$ & 1.850 & 1.349 & 1.685 & 1.735 & 1.784 & 1.000 & 2.000 & 1.169 \\
\hline \multirow[b]{3}{*}{$u$} & Media & 228.375 & 286.250 & 329.500 & 145.192 & 147.500 & 135.000 & 113.750 & 146.250 \\
\hline & SD & 139.013 & 310.865 & 228.572 & 72.100 & 68.191 & 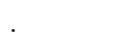 & 91.047 & 88.259 \\
\hline & $\mathrm{CV}$ & 0.609 & 1.086 & 0.694 & 0.497 & 0.462 & 1.000 & 0.800 & 0.603 \\
\hline
\end{tabular}

\subsubsection{Custos totais}

O cálculo dos custos totais foi obtido a partir da soma dos custos fixos e dos custos variáveis, por semana. Na Figura 29 é possível observar a distribuição de custos absolutos e os menores foram despendidos na estação seca, nas zonas de transição $(\mathrm{Ct}=\mathrm{R} \$ 127,69)$ e fluvial/braço Tietê (Ct=R\$153,58). Os maiores custos foram registrados na estação chuvosa, nas zonas de transição ( $C t=R \$ 348,30)$ e fluvial/braço Tietê $(C t=R \$ 307,26)$ (Figura 31).

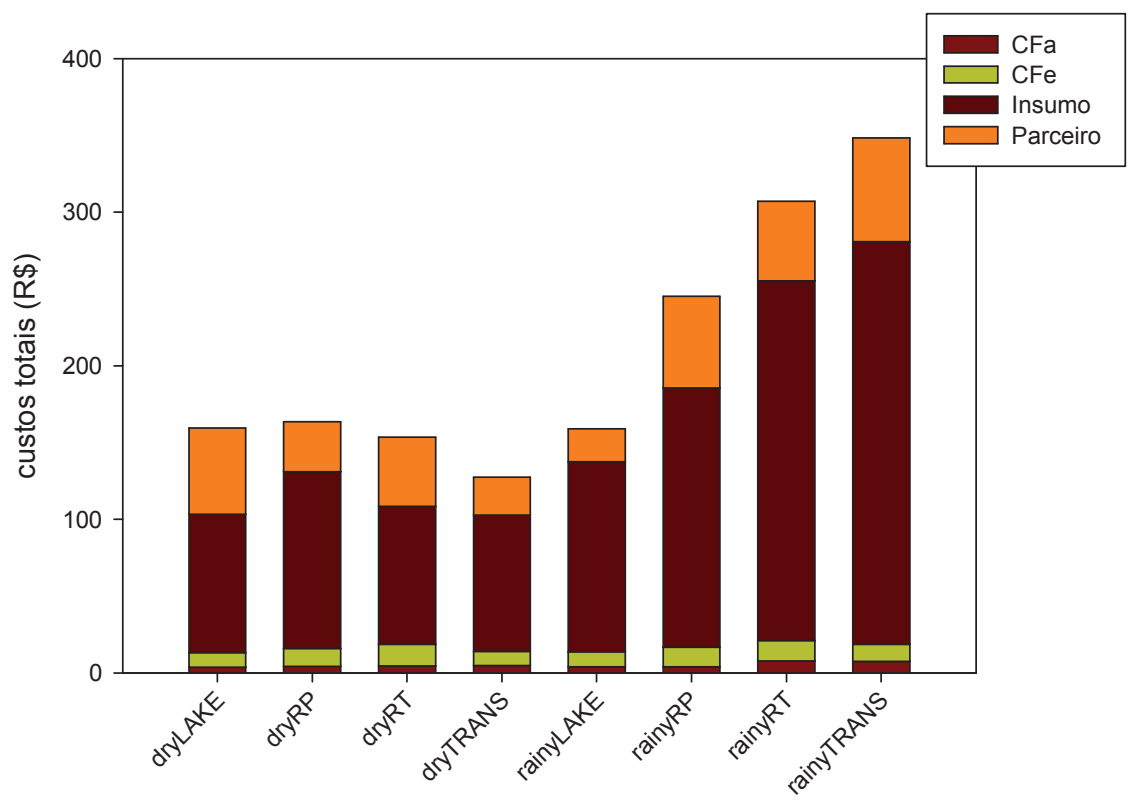

Figura 31: Distribuição dos custos semanais totais absolutos para as pescarias de Barra Bonita (Cfa= custo fixo semanal unitário do petrecho; $\mathrm{Cfe}=$ custo fixo semanal unitário da embarcação; Insumos=gasto semanal com gasolina e óleo para motor; Parceiro= pagamento semanal de parceiro/ajudante; dryLAKE= estação seca, zona lacustre; dryRP= estação seca, zona fluvial/braço Piracicaba; dryRT= estação seca, zona fluvial/braço Tietê; dryTRANS= estação seca, zona de transição; rainyLAKE= estação chuvosa, zona lacustre; rainyRP= estação chuvosa, zona fluvial/braço Piracicaba; rainyRT= estação chuvosa, zona fluvial/braço Tietê; rainyTRANS= estação chuvosa, zona de transição). 
A distribuição relativa dos custos semanais mostra que os maiores custos foram referentes ao pagamento de combustível e óleo (Insumo) em ambas estações e todas as zonas da represa. Relativamente, os menores custos empregados nas pescarias foram os dos petrechos de pesca (Figura 32).

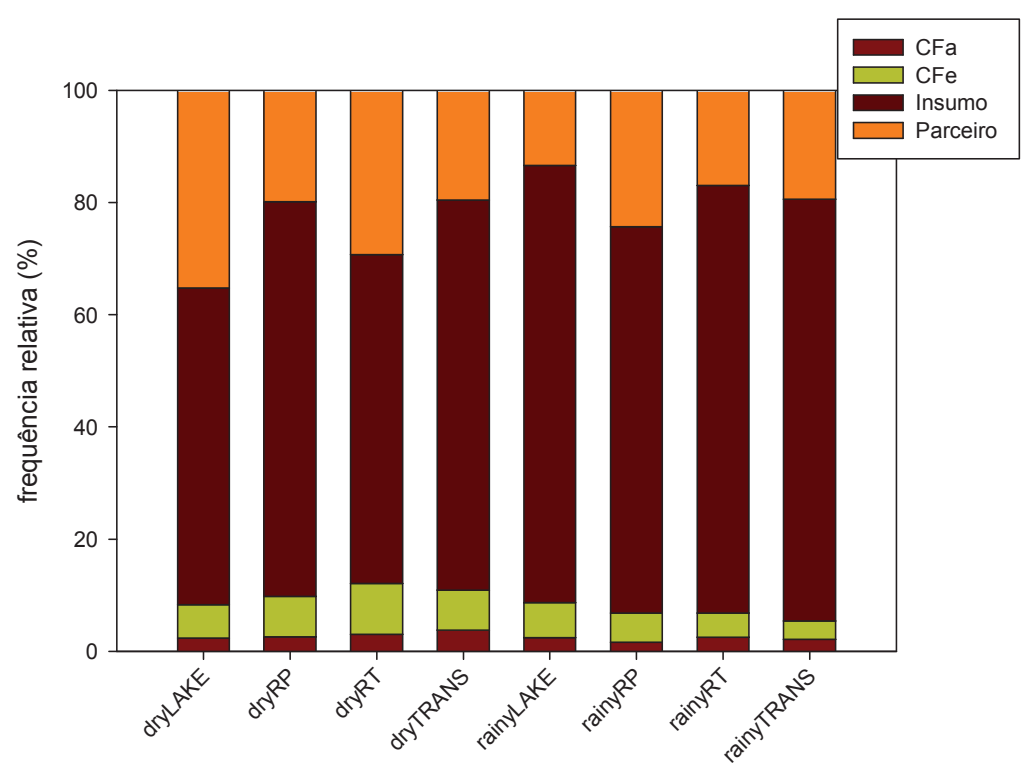

Figura 32: Distribuição dos custos semanais totais relativos para as pescarias de Barra Bonita (Cfa= custo fixo semanal unitário do petrecho; $\mathrm{Cfe}=$ custo fixo semanal unitário da embarcação; Insumos=gasto semanal com gasolina e óleo para motor; Parceiro= pagamento semanal de parceiro/ajudante; dryLAKE= estação seca, zona lacustre; dryRP= estação seca, zona fluvial/braço Piracicaba; dryRT= estação seca, zona fluvial/braço Tietê; dryTRANS= estação seca, zona de transição; rainyLAKE= estação chuvosa, zona lacustre; rainyRP= estação chuvosa, zona fluvial/braço Piracicaba; rainyRT= estação chuvosa, zona fluvial/braço Tietê; rainyTRANS= estação chuvosa, zona de transição).

\subsubsection{Renda}

As espécies que foram capturadas em todas as zonas e em ambas as estações do ano foram tilápia, mandi e corvina. O maior valor médio de comercialização foi de R\$2,51 para a tilápia (estação chuvosa, zona de transição) e para a corvina (estação seca, zona fluvial/braço Piracicaba). Houve menção à comercialização de dourado e pacu a R\$10,00 (Tabela 24). 
Tabela 24: Valor de comercialização dos peixes capturados na represa de Barra Bonita, de acordo com a estação do ano e zona da represa. RP = zona fluvial/braço Piracicaba; RT = zona fluvial/braço Tietê; Trans = zona de transição; Lake = zona lacustre.

\begin{tabular}{|c|c|c|c|c|c|c|c|c|}
\hline Espécie & Estação & Zona & $\mathrm{N}$ & Min & Max & Média & SD & $\mathrm{CV}$ \\
\hline \multirow{8}{*}{ Tilápia } & \multirow{4}{*}{ Seca } & Lake & 11 & 1,00 & 5,00 & 2,01 & 1,41 & 0,70 \\
\hline & & $\mathrm{RP}$ & 25 & 0,80 & 7,00 & 1,37 & 1,26 & 0,92 \\
\hline & & RT & 6 & 0,90 & 1,00 & 0,97 & 0,05 & 0,05 \\
\hline & & Trans & 8 & 0,80 & 1,20 & 1,00 & 0,11 & 0,11 \\
\hline & \multirow{4}{*}{ Chuvosa } & Lake & 12 & 1,00 & 4,70 & 2,34 & 1,52 & 0,62 \\
\hline & & $\mathrm{RP}$ & 23 & 1,00 & 6,00 & 2,43 & 1,55 & 0,64 \\
\hline & & RT & 22 & 1,00 & 4,70 & 1,85 & 1,11 & 0,60 \\
\hline & & Trans & 4 & 1,00 & 4,70 & 2,51 & 1,72 & 0,68 \\
\hline \multirow{7}{*}{ Corvina } & \multirow{3}{*}{ Seca } & Lake & 6 & 0,80 & 1,40 & 1,10 & 0,21 & 0,19 \\
\hline & & $\mathrm{RP}$ & 12 & 1,00 & 8,00 & 2,51 & 2,10 & 0,83 \\
\hline & & Trans & 3 & 1,50 & 1,15 & 1,15 & 0,00 & 0,00 \\
\hline & \multirow{4}{*}{ Chuvosa } & Lake & 4 & 0,50 & 1,50 & 1,8 & 0,47 & 0,40 \\
\hline & & $\mathrm{RP}$ & 12 & 0,80 & 3,25 & 1,85 & 0,73 & 0,40 \\
\hline & & RT & 2 & 2,00 & 3,00 & 2,50 & 0,71 & 0,28 \\
\hline & & Trans & 3 & 1,30 & 1,75 & 1,45 & 0,26 & 0,18 \\
\hline \multirow{8}{*}{ Mandi } & \multirow{4}{*}{ Seca } & Lake & 8 & 0,80 & 3,30 & 1,49 & 0,77 & 0,52 \\
\hline & & $\mathrm{RP}$ & 16 & 1,00 & 3,00 & 1,53 & 0,50 & 0,33 \\
\hline & & RT & 1 & 1,00 & 1,00 & 1,00 & 0,00 & 1,00 \\
\hline & & Trans & 1 & 1,80 & 1,80 & 1,80 & 0,00 & 1,00 \\
\hline & \multirow{4}{*}{ Chuvosa } & Lake & 8 & 1,00 & 2,50 & 1,55 & 0,48 & 0,31 \\
\hline & & $\mathrm{RP}$ & 17 & 1,20 & 2,80 & 1,74 & 0,52 & 0,30 \\
\hline & & RT & 5 & 1,00 & 3,00 & 2,04 & 0,89 & 0,43 \\
\hline & & Trans & 3 & 1,30 & 1,50 & 1,37 & 0,12 & 0,08 \\
\hline \multirow{2}{*}{ Cará } & Seca & Lake & 1 & 1,00 & 1,00 & 1,00 & 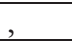 & 1,00 \\
\hline & Chuvosa & RT & 1 & 1,00 & 1,00 & 1,00 & 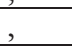 & 1,00 \\
\hline \multirow[t]{2}{*}{ Dourado } & Seca & $\mathrm{RP}$ & 3 & 5,00 & 7,00 & 6,33 & 1,16 & 0,18 \\
\hline & Chuvosa & $\mathrm{RP}$ & 1 & 10,00 & 10,00 & 10,00 & 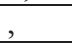 & 1,00 \\
\hline \multirow[t]{3}{*}{ Lambari } & Seca & $\mathrm{RP}$ & 2 & 2,00 & 4,00 & 3,00 & 1,41 & 0,47 \\
\hline & \multirow{2}{*}{ Chuvosa } & Lake & 1 & 1,50 & 1,50 & 1,50 & , & 1,00 \\
\hline & & $\mathrm{RP}$ & 6 & 1,00 & 10,00 & 3,75 & 3,21 & 0,86 \\
\hline \multirow{7}{*}{ Corimba } & \multirow{3}{*}{ Seca } & Lake & 1 & 0,50 & 0,50 & 0,50 & 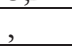 & 1,00 \\
\hline & & $\mathrm{RP}$ & 1 & 2,00 & 2,00 & 2,00 & , & 1,00 \\
\hline & & RT & 1 & 0,50 & 0,50 & 0,50 & , & 1,00 \\
\hline & \multirow{4}{*}{ Chuvosa } & Lake & 6 & 0,50 & 1,20 & 0,77 & 0,29 & 0,38 \\
\hline & & $\mathrm{RP}$ & 17 & 0,50 & 0,50 & 0,92 & 0,34 & 0,37 \\
\hline & & RT & 6 & 0,50 & 2,00 & 1,08 & 0,67 & 0,61 \\
\hline & & Trans & 1 & 0,40 & 0,40 & 0,40 & 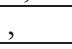 & 1,00 \\
\hline Sardinha & Seca & $\mathrm{RP}$ & 1 & 2,00 & 2,00 & 2,00 & , & 1,00 \\
\hline & & Lake & 4 & 0,80 & 2,00 & 1,45 & 0,64 & 0,44 \\
\hline & Seca & RT & 1 & 0,50 & 0,50 & 0,50 & , & 1,00 \\
\hline & & Trans & 1 & 1,00 & 1,00 & 1,00 & s & 1,00 \\
\hline Cascudo & & Lake & 4 & 2,50 & 3,50 & 2,75 & 0,50 & 0,18 \\
\hline & & RP & 8 & 2,00 & 4,00 & 2,94 & 0,68 & 0,23 \\
\hline & Chuvosa & RT & 6 & 1,50 & 3,50 & 2,42 & 0,92 & 0,38 \\
\hline & & Trans & 1 & 2,50 & 2,50 & 2,50 & 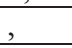 & 1,00 \\
\hline Pacu & Seca & $\mathrm{RP}$ & 2 & 4,50 & 5,00 & 4,75 & 0,35 & 0,07 \\
\hline & Chuvosa & $\mathrm{RP}$ & 1 & 10,00 & 10,00 & 10,00 & , & 1,00 \\
\hline Piapara & Seca & RT & 1 & 1,20 & 1,20 & 1,20 & , & 1,00 \\
\hline & Chuvosa & $\mathrm{RP}$ & 1 & 2,00 & 2,00 & 2,00 & , & 1,00 \\
\hline Traíra & Seca & $\mathrm{RP}$ & 1 & 1,50 & 1,50 & 1,50 & & 1,00 \\
\hline & & $\mathrm{RP}$ & 3 & 2,00 & 3,50 & 2,83 & 0,76 & 0,27 \\
\hline & Chuvosa & Trans & 1 & 2,50 & 2,50 & 2,50 & 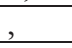 & 1,00 \\
\hline Piau & Chuvosa & $\mathrm{RP}$ & 4 & 1,50 & 2,00 & 1,55 & 0,33 & 0,21 \\
\hline Piranha & & $\mathrm{RP}$ & 1 & 4,00 & 4,00 & 4,00 & , & 1,00 \\
\hline & Chuvosa & RT & 1 & 2,00 & 2,00 & 2,00 & , & 1,00 \\
\hline & & Trans & 1 & 0,40 & 0,40 & 0,40 & 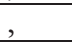 & 1,00 \\
\hline
\end{tabular}


A distribuição semanal de renda mostrou que o maior valor médio foi obtido na estação chuvosa, zona de transição $(R \$ 385,45)$. Durante a estação chuvosa foi obtida a maior renda ( $\mathrm{R} \$ 4089,00$, zona fluvial/braço Tietê), enquanto a menor foi registrada durante a estação seca ( $R \$ 18,00$, zona lacustre) (Tabela 25).

A espécie que possibilitou o maior retorno econômico foi a tilápia $(R \$ 4089,00)$ na estação chuvosa, zona fluvial/braço Tietê, e nenhuma outra espécie teve tal desempenho.

Os retornos máximos do mandi e da corvina foram de $\mathrm{R} \$ 700,00$ e $\mathrm{R} \$ 400,00$, respectivamente (Figura 33).

Tabela 25: Distribuição dos valores semanais da renda obtida pela comercialização dos peixes capturados pela pesca artesanal de Barra Bonita, onde dryLAKE= estação seca, zona lacustre; dryRP= estação seca, zona fluvial/braço Piracicaba; dryRT= estação seca, zona fluvial/braço Tietê; dryTRANS= estação seca, zona de transição; rainyLAKE= estação chuvosa, zona lacustre; rainyRP= estação chuvosa, zona fluvial/braço Piracicaba; rainyRT= estação chuvosa, zona fluvial/braço Tietê; rainyTRANS= estação chuvosa, zona de transição)

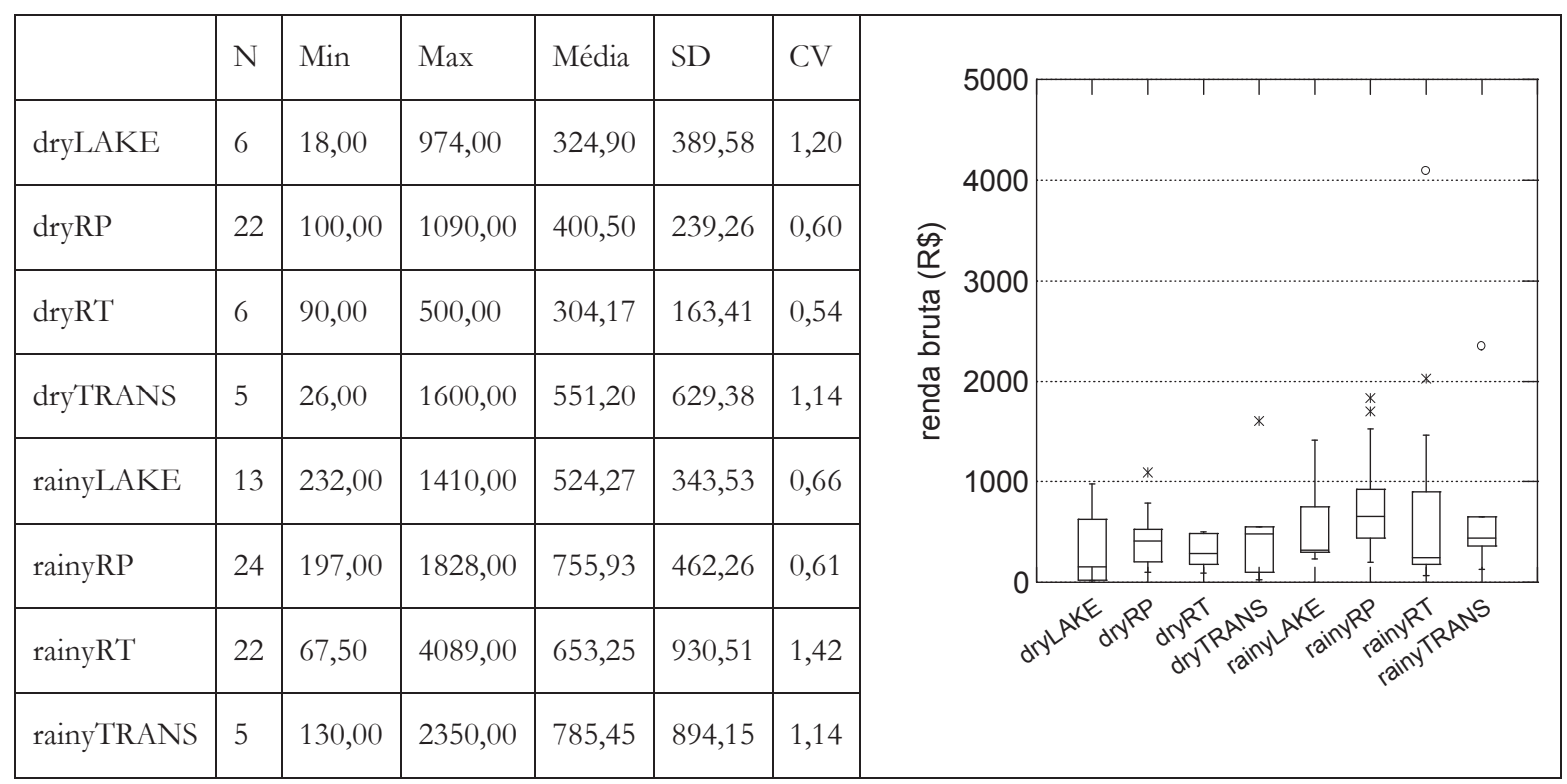



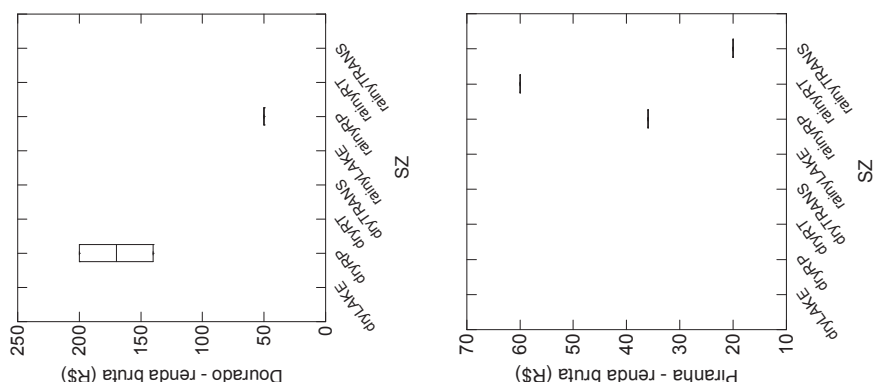

e) ełnıq ерuә - ope.noo

(\$у) ęnıq ерuәл - ецueग!d

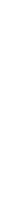

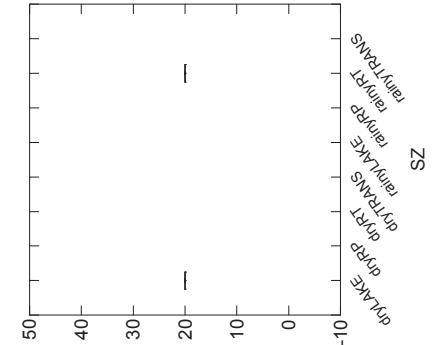

(\$4) ęnıq epuəd - ẹıeว

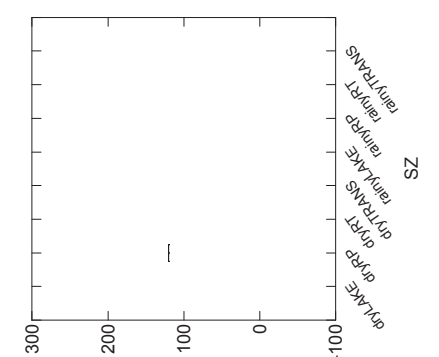

(\$4) eұnıq epuəd - ечu!pses

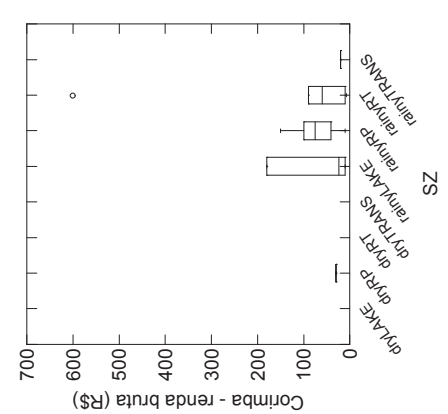

(\$) ełnıq ерuəл - !puew
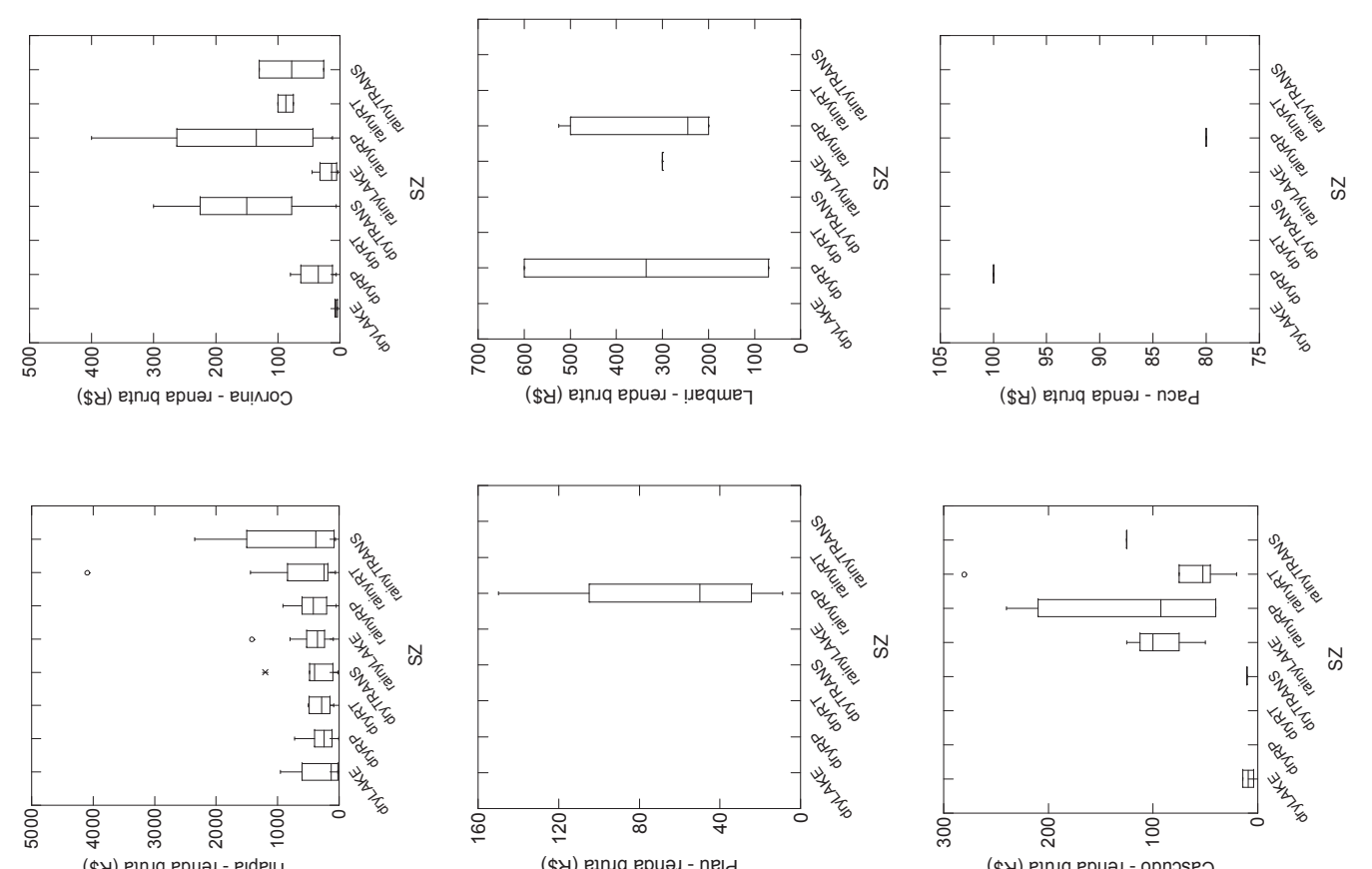

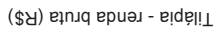
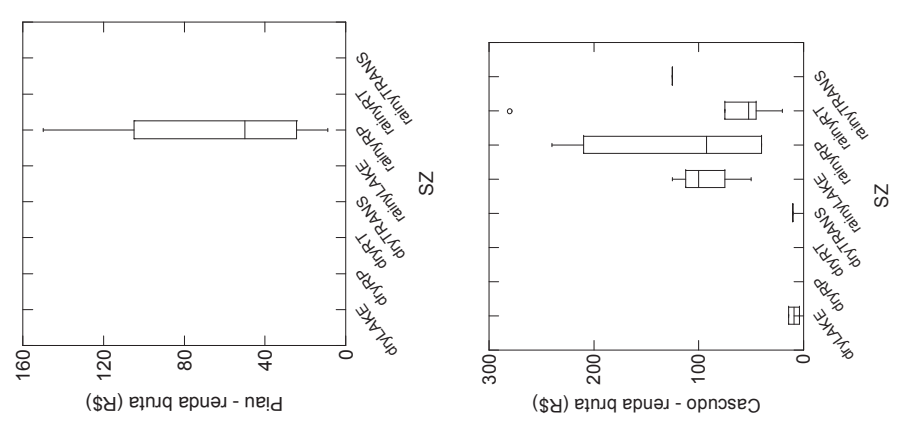

(\$у) eұnıq ериәл - opnoseว

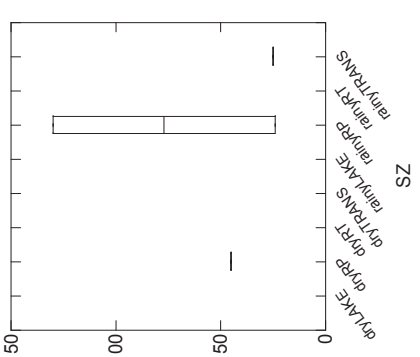

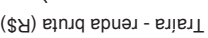

(\$) ęnıq epuəл - esede!d

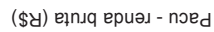

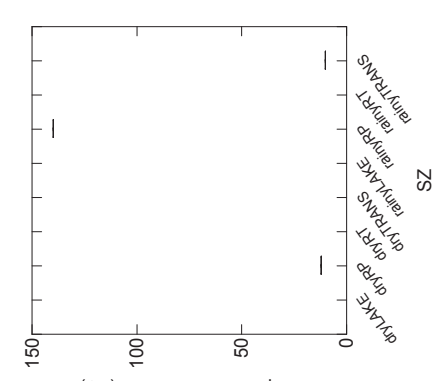




\subsubsection{Lucro total}

O calculo dos lucros indicou que os pescadores entrevistados na estação chuvosa, zona fluvial/braço Tietê obtiveram os maiores lucros ( $R$ \$ $2.983,50)$, enquanto os da estação seca, zona fluvial/braço Tietê, o menor (R\$26,42) (Tabela 26).

Tabela 26: Distribuição dos valores semanais da renda obtida pela comercialização dos peixes capturados pela pesca artesanal de Barra Bonita, onde dryLAKE= estação seca, zona lacustre; dryRP= estação seca, zona fluvial/braço Piracicaba; dryRT= estação seca, zona fluvial/braço Tietê; dryTRANS= estação seca, zona de transição; rainyLAKE= estação chuvosa, zona lacustre; rainyRP= estação chuvosa, zona fluvial/braço Piracicaba; rainyRT= estação chuvosa, zona fluvial/braço Tietê; rainyTRANS= estação chuvosa, zona de transição)

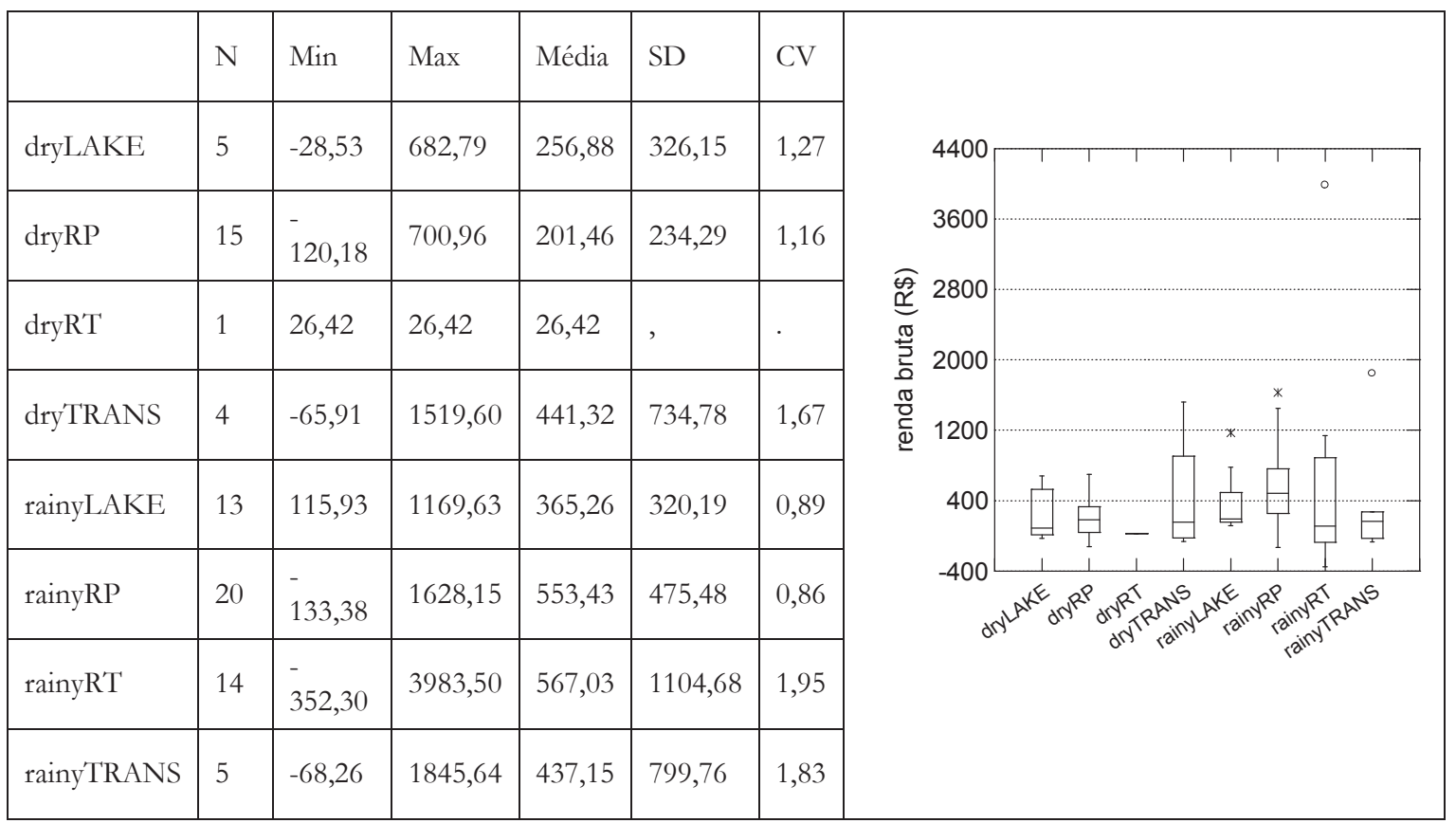

\subsubsection{Análise lucro calculado X lucro declarado}

O tipo de dispersão entre as variáveis RC (renda calculada) e RD (renda declarada) foi examinado através da análise de correlação e a ausência de outliers foi checada. O baixo valor de $r$ reflete o pequeno ajuste entre as informações das rendas declaradas pelos pescadores (Figura 34). 
Means

\begin{tabular}{rr}
\hline RO & RD \\
\hline 407.576 & 1316.267 \\
\hline
\end{tabular}

Pearson correlation matrix

\begin{tabular}{ccc}
\hline & RO & RD \\
\hline RO & 1.000 & \\
RD & 0.179 & 1.000 \\
\hline
\end{tabular}

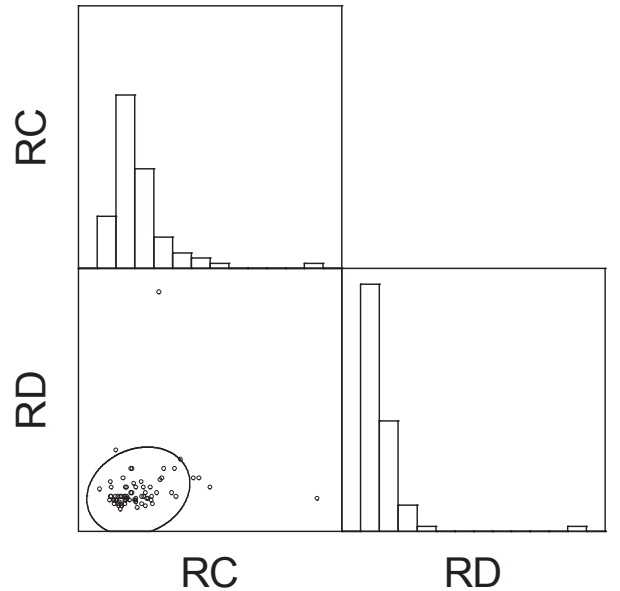

Figura 34: (A) Análise de correlação entre os dados das rendas calculadas (RC) e as rendas declaradas (RD) pelos pesadores e (B) Análise de correlação entre os dados das rendas declaradas (RD) e das rendas calculadas $(\mathrm{RC})$.

\subsubsection{Análises estatísticas}

A Figura 35 mostra as relações positivas entre $\ln L$ e $\operatorname{lnf}(a), \ln L$ e $\operatorname{lnl}($ b) e $\ln L$ e $\ln T$, que podem ser tomada como lineares, embora com bastante dispersão.

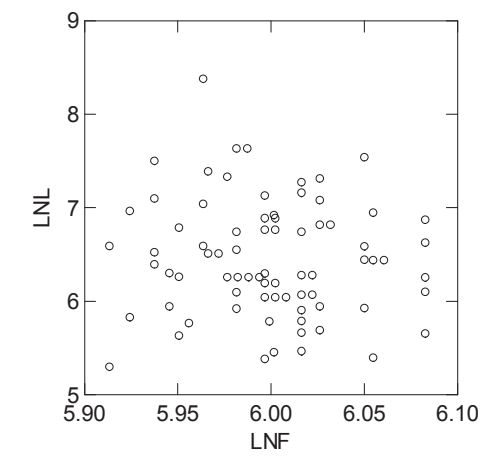

A

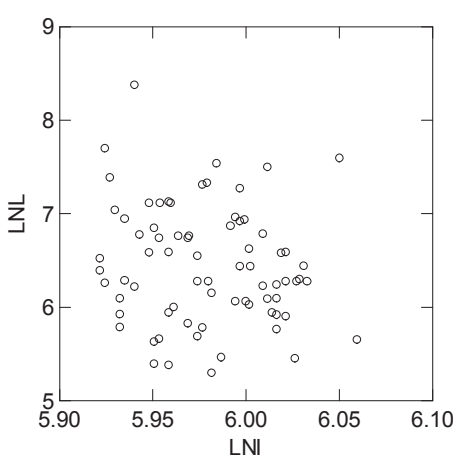

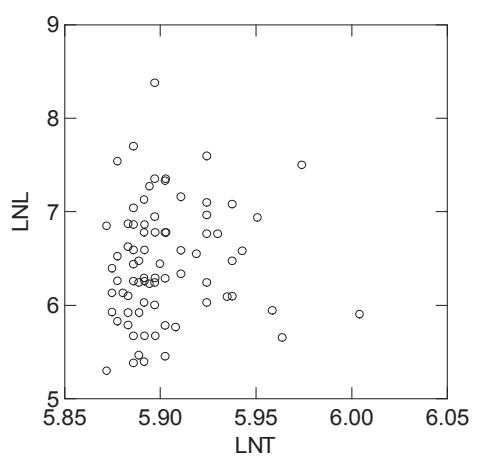

Figura 35: (a) Relação entre InL (logaritmo neperiano do lucro, em reais) e Inf (logaritmo neperiano do esforço, em termos de número de dias de pescaria por semana); (b) Relação entre InL (logaritmo neperiano do lucro, em reais) e Inl (logaritmo neperiano da idade dos pescadores, em termos de número de anos); (c) Relação entre InL (logaritmo neperiano do lucro, em reais) e InT (logaritmo neperiano da experiência dos pescadores, em termos de número de anos)

No modelo testado inicialmente foram considerados $\operatorname{lnL}$ a variável dependente, $\operatorname{lnT}$, Inl e Inf as variáveis independentes e os fatores S, Z, Ec, In, E e P (variáveis independentes: estação do ano, zona da represa, estado civil, grau de instrução, material da embarcação e petrechos e artes de pesca) conforme a equação:

$$
\ln L=\mu+Z+S+E_{C}+\operatorname{In}+E+P+\ln I+\ln T+\ln f+\varepsilon
$$


A Tabela 27 apresenta os modelos da ANCOVA stepwise e o modelo final, $\ln L=\mu+I+\varepsilon$, após a retirada dos fatores e da covariável cujos valores de $\mathrm{p}>0,05$.

\section{Tabela 27: Resultados da ANCOVA stepwise}

$\ln L=\mu+Z+S+E_{C}+\operatorname{In}+E+P+\ln I+\ln T+\ln f+\varepsilon$ para os dados agrupados das pesarias artesanais, onde LNL a variável dependente (logaritmo do lucro), LNT, LNI e LNF as variáveis independentes (logaritmos do tempo de experiência, da idade e do esforço de pesca), e S, Z, EC, IN, E E P os fatores (estação do ano, zona da represa, estado civil, graus de instrução, material da embarcação e petrechos e artes de pesca)

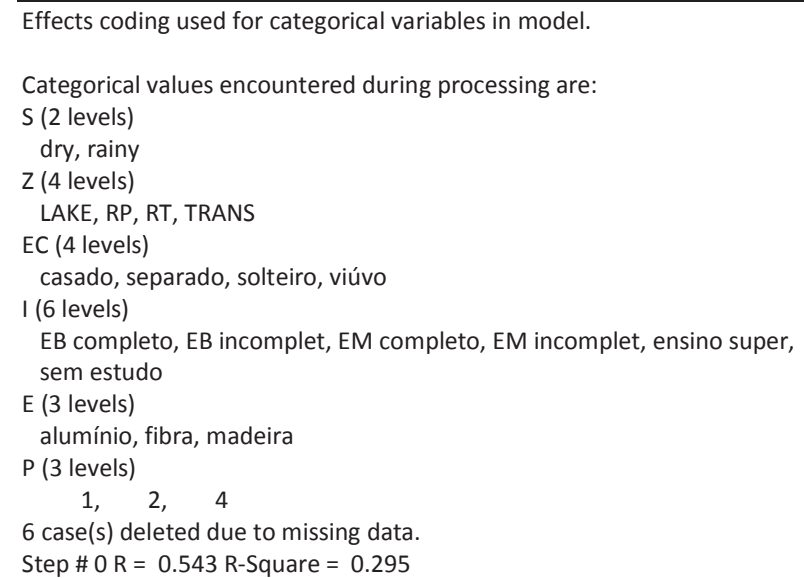

\begin{tabular}{|c|c|c|c|c|c|c|c|}
\hline & Effect & Coefficient & Std Error & Std Coef & $\mathrm{df}$ & $\mathrm{F}$ & 'P' \\
\hline \multicolumn{8}{|l|}{ In } \\
\hline 1 & Constant & & & & & & \\
\hline 2 & LNI & -3.641 & 3.072 & -0.1960 .50559 & 1 & 1.405 & 0.241 \\
\hline 3 & LNE & 3.389 & 4.338 & 0.1400 .43324 & 1 & 0.610 & 0.438 \\
\hline 4 & LNF & -1.055 & 2.171 & -0.0690 .68070 & 1 & 0.236 & 0.629 \\
\hline 5 & $\mathrm{S \$}$ & -0.150 & 0.094 & -0.2270 .67987 & 1 & 2.538 & 0.117 \\
\hline 6 & $Z \$$ & . & . & 0.62403 & 3 & 0.209 & 0.889 \\
\hline 7 & EC\$ & . & . & 0.47929 & 3 & 0.735 & 0.536 \\
\hline 8 & I\$ & . & . & 0.17995 & 5 & 2.033 & 0.090 \\
\hline 9 & $E \$$ & . & . & 0.39996 & 2 & 0.233 & 0.793 \\
\hline 10 & $P$ & . & . & 0.41825 & 2 & 0.367 & 0.695 \\
\hline Out & none & Part. Corr. & & & & & \\
\hline
\end{tabular}

>STEP / AUTO

Dependent Variable LNL

Minimum tolerance for entry into model $=0.000000$

Backward stepwise with Alpha-to-Enter $=0.050$ and Alpha-to-Remove $=0.050$

Step \# $1 \mathrm{R}=0.535 \mathrm{R}$-Square $=0.286$

Term removed: $Z$ 


\begin{tabular}{|c|c|c|c|c|c|c|c|c|}
\hline & Effect & Coefficient & Std Error & Std Coef & Tol. & $\mathrm{df}$ & $\mathrm{F}$ & 'P' \\
\hline \multicolumn{9}{|l|}{ In } \\
\hline 1 & Constant & & & & & & & \\
\hline 2 & LNI & -4.066 & 2.922 & -0.219 & 0.53414 & 1 & 1.936 & 0.170 \\
\hline 3 & LNE & 4.492 & 3.973 & 0.185 & 0.49377 & 1 & 1.278 & 0.263 \\
\hline 4 & LNF & -0.674 & 1.987 & -0.044 & 0.77714 & 1 & 0.115 & 0.736 \\
\hline 5 & $S$ & -0.129 & 0.085 & -0.196 & 0.80071 & 1 & 2.315 & 0.134 \\
\hline 7 & EC & . & . & . & 0.48502 & 3 & 0.688 & 0.563 \\
\hline 8 & 1 & . & . & . & 0.18053 & 5 & 2.004 & 0.093 \\
\hline 9 & $E$ & . & . & . & 0.42582 & 2 & 0.441 & 0.646 \\
\hline 10 & $\mathrm{P}$ & . & . & . & 0.46866 & 2 & 0.365 & 0.696 \\
\hline Out & & Part. Corr. & & & & & & \\
\hline 6 & Z &. & . & . & . & 3 & 0.209 & 0.889 \\
\hline \multicolumn{9}{|c|}{$\begin{array}{l}\text { Step \# } 2 \mathrm{R}=0.533 \mathrm{R}-\mathrm{Square}=0.285 \\
\text { Term removed: LNF }\end{array}$} \\
\hline & Effect & Coefficient & Std Error & Std Coef & Tol. & $\mathrm{df}$ & $\mathrm{F}$ & 'P' \\
\hline \multicolumn{9}{|l|}{ In } \\
\hline 1 & Constant & & & & & & & \\
\hline 2 & LNI & -4.197 & 2.874 & -0.226 & 0.54357 & 1 & 2.133 & 0.150 \\
\hline 3 & LNE & 4.587 & 3.931 & 0.189 & 0.49624 & 1 & 1.362 & 0.248 \\
\hline 5 & $S$ & -0.133 & 0.084 & -0.201 & 0.81229 & 1 & 2.515 & 0.118 \\
\hline 7 & EC & . & . & . & 0.51384 & 3 & 0.791 & 0.504 \\
\hline 8 & 1 & . & . & . & 0.18305 & 5 & 2.020 & 0.090 \\
\hline 9 & $E$ & . & . & . & 0.42692 & 2 & 0.459 & 0.634 \\
\hline 10 & $\mathrm{P}$ & . & . & . & 0.48322 & 2 & 0.327 & 0.723 \\
\hline Out & & Part. Corr. & & & & & & \\
\hline 4 & LNF & -0.046 & . & . & 0.77714 & 1 & 0.115 & 0.736 \\
\hline 6 & Z & . & . & . & . & 3 & 0.170 & 0.916 \\
\hline \multicolumn{9}{|c|}{$\begin{array}{l}\text { Step \# } 3 \mathrm{R}=0.525 \mathrm{R} \text {-Square }=0.276 \\
\text { Term removed: } \mathrm{P}\end{array}$} \\
\hline & Effect & Coefficient & Std Error & Std Coef & Tol. & $\mathrm{df}$ & $\mathrm{F}$ & 'P' \\
\hline \multicolumn{9}{|l|}{$\ln$} \\
\hline 1 & Constant & & & & & & & \\
\hline 2 & LNI & -4.295 & 2.777 & -0.231 & 0.56812 & 1 & 2.391 & 0.128 \\
\hline 3 & LNE & 4.872 & 3.858 & 0.201 & 0.50295 & 1 & 1.595 & 0.212 \\
\hline 5 & $S$ & -0.127 & 0.082 & -0.193 & 0.82358 & 1 & 2.409 & 0.126 \\
\hline 7 & EC & . & . & . & 0.51976 & 3 & 0.830 & 0.483 \\
\hline 8 & 1 & . & . & . & 0.18642 & 5 & 2.117 & 0.076 \\
\hline 9 & $E$ & . & . & . & 0.43585 & 2 & 0.467 & 0.629 \\
\hline Out & & Part. Corr. & & & & & & \\
\hline 4 & LNF & -0.023 & . & . & 0.81106 & 1 & 0.029 & 0.865 \\
\hline 6 & Z & . & . & . & . & 3 & 0.181 & 0.909 \\
\hline 10 & $\mathrm{P}$ & . & . & . & . & 2 & 0.327 & 0.723 \\
\hline \multicolumn{9}{|c|}{$\begin{array}{l}\text { Step \# } 4 \mathrm{R}=0.514 \mathrm{R} \text {-Square }=0.264 \\
\text { Term removed: } \mathrm{E}\end{array}$} \\
\hline & Effect & Coefficient & Std Error & Std Coef & Tol. & $\mathrm{df}$ & $\mathrm{F}$ & 'P' \\
\hline \multicolumn{9}{|l|}{$\ln$} \\
\hline 1 & Constant & & & & & & & \\
\hline 2 & LNI & -3.845 & 2.688 & -0.207 & 0.59542 & 1 & 2.046 & 0.158 \\
\hline 3 & LNE & 3.113 & 3.258 & 0.128 & 0.69264 & 1 & 0.913 & 0.343 \\
\hline 5 & $\mathrm{~S}$ & -0.140 & 0.079 & -0.213 & 0.86716 & 1 & 3.145 & 0.081 \\
\hline 7 & EC & . & . & . & 0.54491 & 3 & 1.103 & 0.355 \\
\hline 8 & 1 & . & . & . & 0.18936 & 5 & 2.245 & 0.061 \\
\hline OuT & & Part. Corr. & & & & & & \\
\hline 4 & LNF & -0.026 & . & . & 0.81731 & 1 & 0.040 & 0.843 \\
\hline 6 & Z & . & . & . & . & 3 & 0.309 & 0.819 \\
\hline 9 & $E$ & . & . & . & . & 2 & 0.467 & 0.629 \\
\hline 10 & $\mathrm{P}$ & . & . & . & . & 2 & 0.330 & 0.720 \\
\hline
\end{tabular}

Step \# 5 R $=0.472$ R-Square $=0.223$

Term removed: EC 


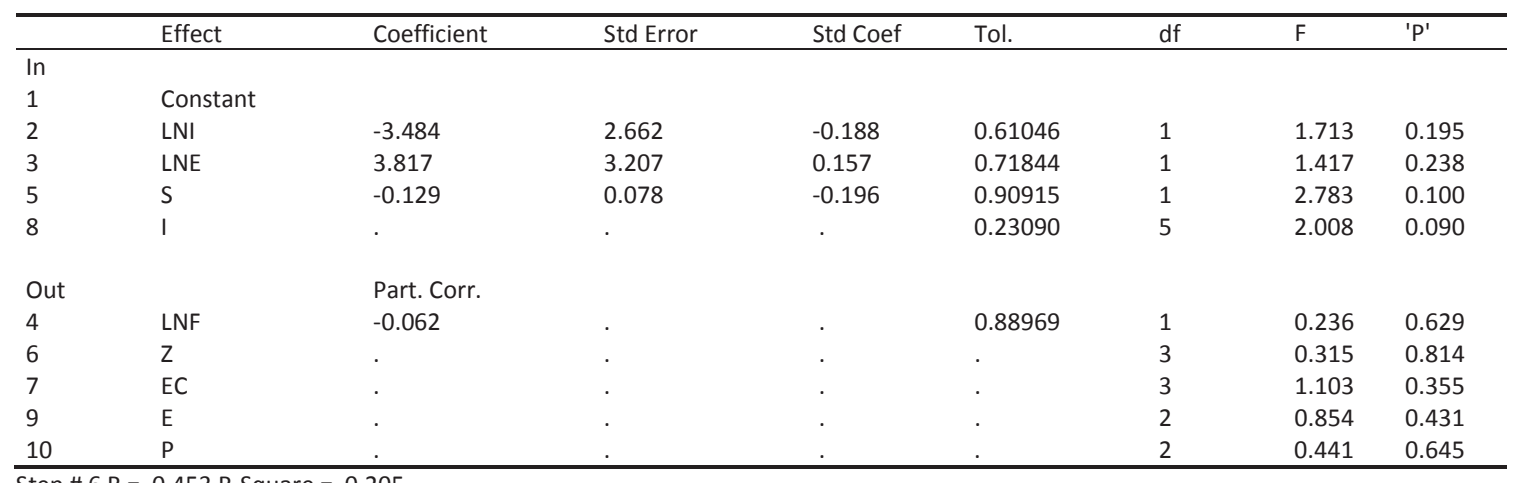

Step \# $6 \mathrm{R}=0.453 \mathrm{R}$-Square $=0.205$

Term removed: LNE

\begin{tabular}{|c|c|c|c|c|c|c|c|c|}
\hline & Effect & Coefficient & Std Error & Std Coef & Tol. & $\mathrm{df}$ & $\mathrm{F}$ & 'P' \\
\hline \multicolumn{9}{|l|}{ In } \\
\hline 1 & Constant & & & & & & & \\
\hline 2 & LNI & -1.940 & 2.332 & -0.104 & 0.80037 & 1 & 0.692 & 0.409 \\
\hline 5 & $S$ & -0.121 & 0.077 & -0.183 & 0.91651 & 1 & 2.442 & 0.123 \\
\hline 8 & I & . & . & . & 0.23336 & 5 & 2.322 & 0.053 \\
\hline Out & & Part. Corr. & & & & & & \\
\hline 3 & LNE & 0.149 & . & . & 0.71844 & 1 & 1.417 & 0.238 \\
\hline 4 & LNF & -0.079 & . & . & 0.90224 & 1 & 0.386 & 0.537 \\
\hline 6 & Z & . & . & . & . & 3 & 0.480 & 0.697 \\
\hline 7 & EC & . & . & . & . & 3 & 1.275 & 0.291 \\
\hline 9 & E & . & . & . & . & 2 & 0.261 & 0.771 \\
\hline 10 & $P$ & . & . & . & . & 2 & 0.523 & 0.595 \\
\hline
\end{tabular}

Step \# $7 \mathrm{R}=0.443 \mathrm{R}$-Square $=0.196$

Term removed: LNI

\begin{tabular}{|c|c|c|c|c|c|c|c|c|}
\hline & Effect & Coefficient & Std Error & Std Coef & Tol. & $\mathrm{df}$ & $\mathrm{F}$ & 'P' \\
\hline \multicolumn{9}{|l|}{ In } \\
\hline 1 & Constant & & & & & & & \\
\hline 5 & $\mathrm{~S}$ & -0.125 & 0.077 & -0.190 & 0.92042 & 1 & 2.639 & 0.109 \\
\hline 8 & 1 & . & . & . & 0.24004 & 5 & 2.486 & 0.040 \\
\hline Out & & Part. Corr. & & & & & & \\
\hline 2 & LNI & -0.104 & . & . & 0.80037 & 1 & 0.692 & 0.409 \\
\hline 3 & LNE & 0.079 & . & . & 0.94194 & 1 & 0.396 & 0.531 \\
\hline 4 & LNF & -0.080 & . & . & 0.90254 & 1 & 0.407 & 0.526 \\
\hline 6 & z & . & . & . & . & 3 & 0.472 & 0.703 \\
\hline 7 & $\mathrm{EC}$ & . & . & . & . & 3 & 1.086 & 0.362 \\
\hline 9 & E & . & . & . & . & 2 & 0.228 & 0.797 \\
\hline 10 & $\mathrm{P}$ & . & . & . & . & 2 & 0.524 & 0.595 \\
\hline
\end{tabular}

Step \# $8 R=0.404$ R-Square $=0.163$

Term removed: $\mathrm{S}$

\begin{tabular}{|c|c|c|c|c|c|c|c|c|}
\hline & Effect & Coefficient & Std Error & Std Coef & Tol. & $\mathrm{df}$ & $\mathrm{F}$ & 'P' \\
\hline \multicolumn{9}{|l|}{ In } \\
\hline 1 & Constant & & & & & & & \\
\hline 8 & 1 & . & . & . & 0.24635 & 5 & 2.536 & 0.037 \\
\hline Out & & Part. Corr. & & & & & & \\
\hline 2 & LNI & -0.115 & . & . & 0.80379 & 1 & 0.856 & 0.358 \\
\hline 3 & LNE & 0.055 & . & . & 0.95345 & 1 & 0.195 & 0.660 \\
\hline 4 & LNF & -0.109 & . & . & 0.92587 & 1 & 0.771 & 0.383 \\
\hline 5 & $S$ & -0.199 & . & . & 0.92042 & 1 & 2.639 & 0.109 \\
\hline 6 & Z & . & . & . & . & 3 & 0.130 & 0.942 \\
\hline 7 & $\mathrm{EC}$ & . & . & . & . & 3 & 0.867 & 0.463 \\
\hline 9 & $E$ & . & . & . & . & 2 & 0.492 & 0.614 \\
\hline 10 & $\mathrm{P}$ & . & . & . & . & 2 & 0.368 & 0.694 \\
\hline
\end{tabular}


No procedimento stepwise, as variáveis com valores de $p$ inferiores a 0,05 são sucessiva e automaticamente desconsideradas do modelo. O modelo $\ln L=\mu+I+\varepsilon$, isto é, uma ANOVA, é o final que melhor explicou a relação entre o lucro das pescarias e o grau de instrução dos pescadores.

Para o modelo final foi feita uma análise de resíduos, cujo histograma está representado na Figura 36. O teste de Lilliefors $(p=0,282)$ para verificação da normalidade mostrou que os dados das variáveis estudadas apresentaram distribuição normal, validando o modelo.

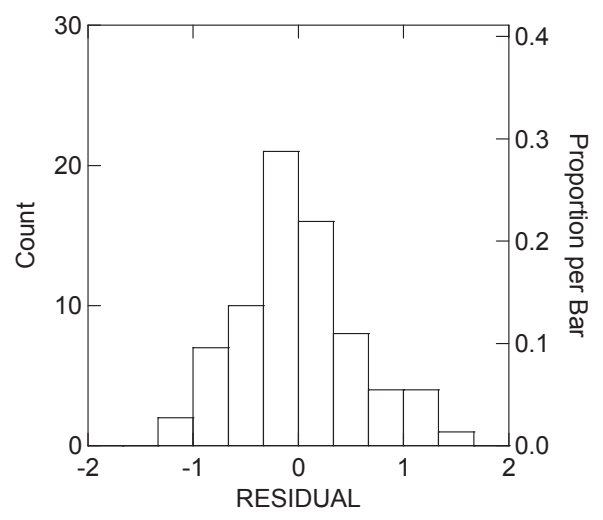

Figura 36: Histograma dos resíduos do modelo final da ANCOVA $\ln L=\mu+I n+\varepsilon$ para os dados agrupados das pescarias artesanais de Barra Bonita, onde In é o grau de instrução dos pescadores e $\varepsilon$ é o erro experimental

O teste de comparação entre as médias (Tabela 28) mostrou haver diferença estatística entre os lucros dos pescadores detentores de Ensino Médio Completo em relação aos que possuíam: (a) Ensino Básico Incompleto: superior; (b) Ensino Médio Incompleto: superior; (c) Ensino Superior: inferior, e (d) Nenhuma educação formal (Sem Estudo): superior. 


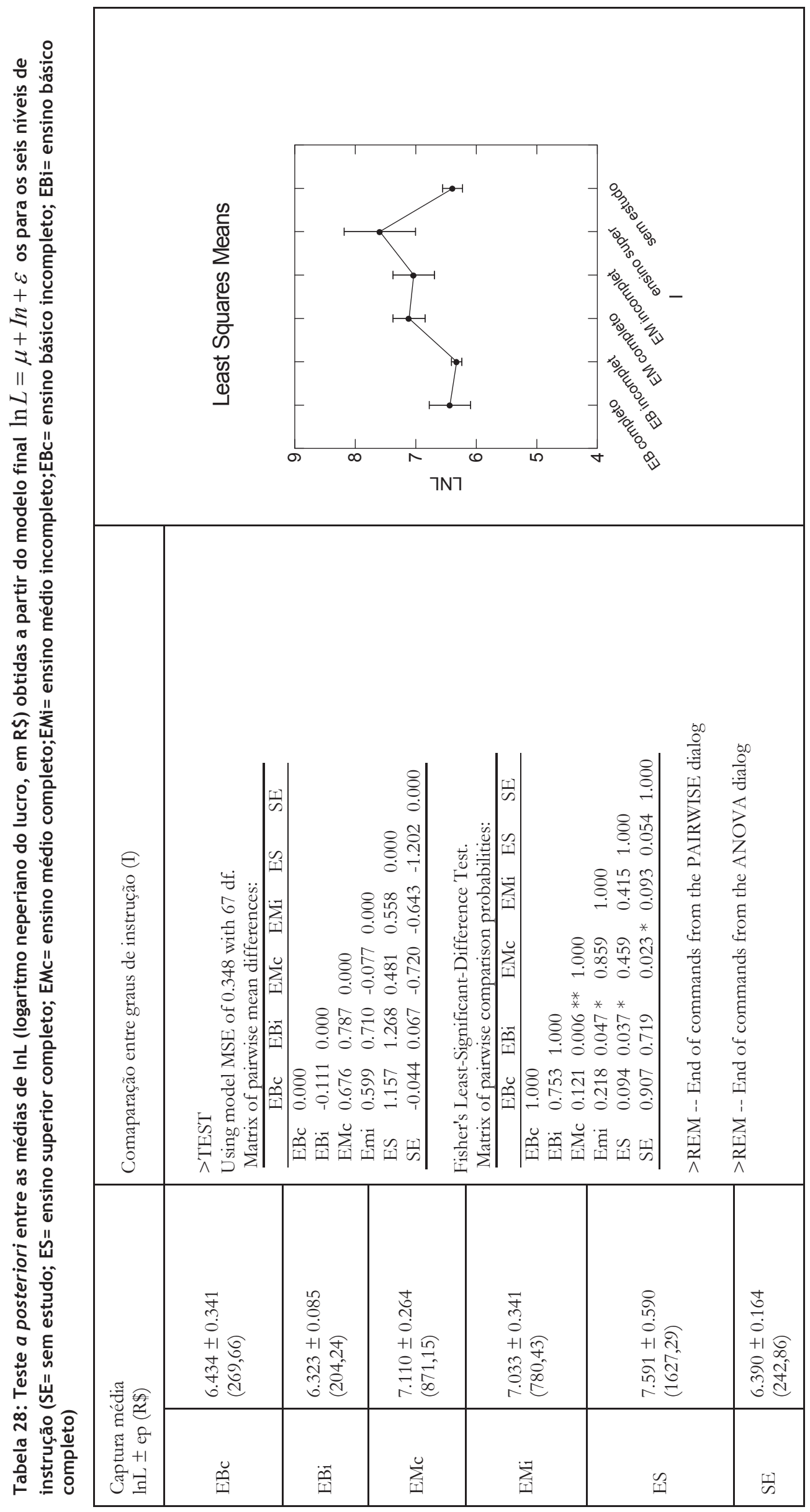




\subsection{DISCUSSÃO}

As comunidades de peixes, enquanto recurso natural, devem ser consideradas não só por seus aspectos biológicos, mas também como um poderoso instrumento econômico para os envolvidos na cadeia produtiva pesqueira, regida pelo mercado, porque constituem importante da alimentação humana em muitos países (Matos, 2004).

O intermediário foi apontado pela maioria dos pescadores como comprador de sua produção, possibilitando a venda em sua embarcação ou casa, com sua presença já identificada (Bayley \& Petrere, 1989; Petrere, 1989). Maruyama (2007) também registrou a presença do intermediário nas pescarias do Médio Tietê e acredita na dependência do pescador em relação ao intermediário advém da falta de estrutura de desembarque, armazenagem e distribuição de gelo. Os pescadores de Barra Bonita apontaram ainda o uso de gelo como forma de conservar o pescado e mencionaram sua aquisição via intermediário (visto que poucos dispõem de transporte particular e o transporte coletivo da região é falho, Capítulo 2). Assim, o intermediário determina os preços de compra do pescado e venda de insumos, podendo, inclusive, assegurar acesso a mantimentos, medicamentos e vestuário durante o período de entressafra (Souza, 2006). É usual que o pescador prefira recorrer ao intermediário para suas operações de pesca e para as necessidades de sua família, pois não há imposição de condições e este supre as necessidades imediatas em troca dos produtos da pesca. Muitas vezes o pescador não recebe o valor justo por suas capturas, mas ainda mantém essa relação de dependência (Beltrán Turriago, 2001).

A presença consolidada do intermediário no sistema de produção de peixes foi descrita por Sonoda (2002). Para as pescarias extrativas, o primeiro segmento representa os fatores de produção e os insumos (custos). O segundo segmento é a pesca propriamente dita, e o terceiro, a transformação do pescado. Nas pescarias artesanais continentais, este segmento tem participação discreta ou inexistente na cadeia do pescado. O quarto segmento representa a distribuição do pescado (Figura 37). No caso das pescarias de Barra Bonita, o papel do intermediário é decisivo, pois são poucos os pescadores que tem autonomia para comercializar sua captura diretamente com os entrepostos (apenas um pescador mencionou esta prática). Alguns (poucos) pescadores comercializavam os peixes diretamente com o consumir final, principalmente com turistas, alcançando valores mais elevados e, consequentemente, maiores retornos econômicos. Vale a pena observar que a 
cadeia descrita para a produção de peixes em cativeiro (piscicultura) possui menos segmentos intermediários e, apesar de ser mais onerosa, quando bem administrada, possibilita maiores rendimentos.

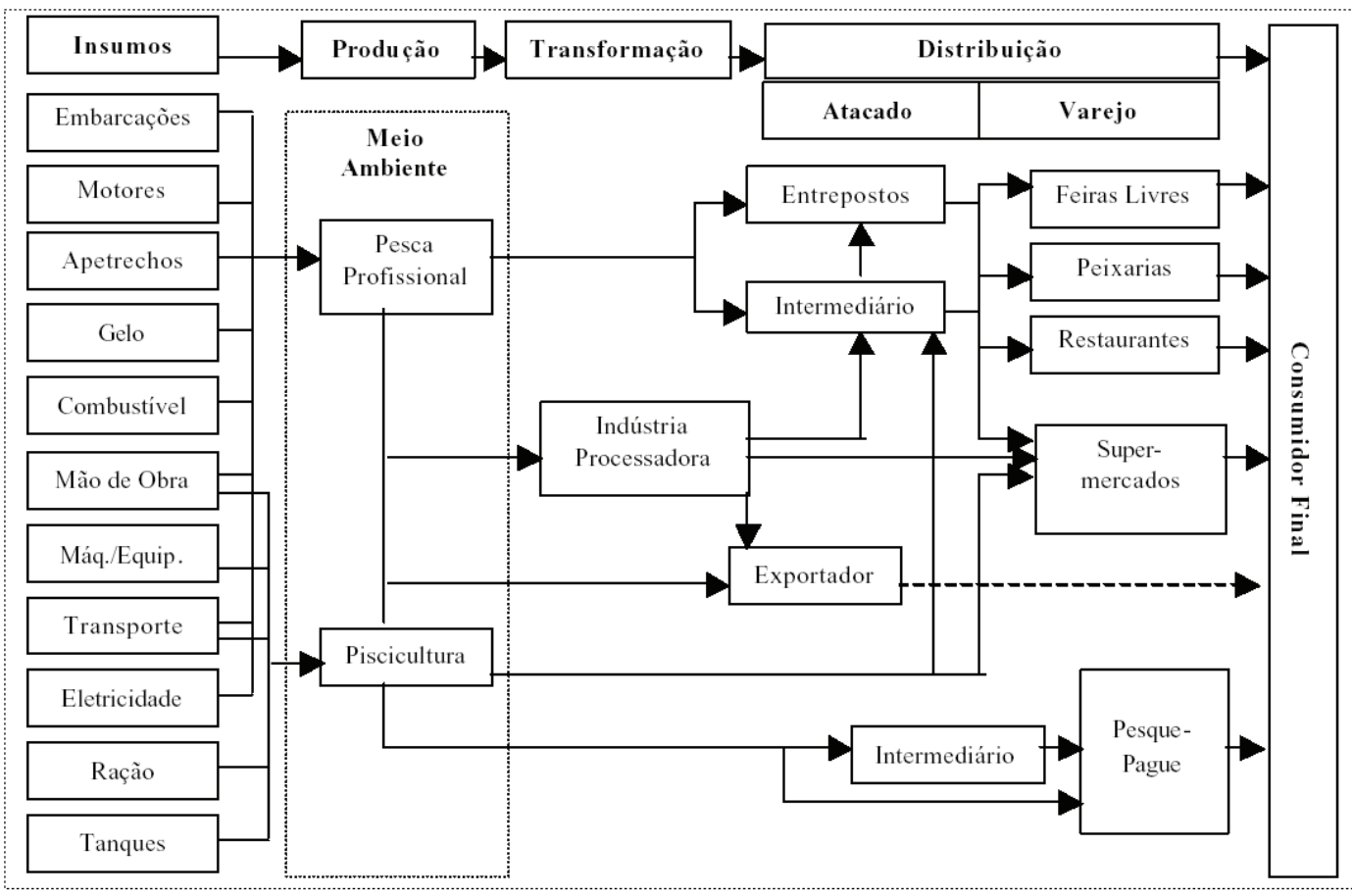

Figura 37: Representação esquemática do Sistema Agroindustrial (SAG) do Pescado. Fonte: Sonoda (2006)

Os custos fixos referentes às embarcações foram calculados de modo agrupado devido à dificuldade em informar os valores do barco e do motor separadamente, pois, na maior parte das vezes, os pescadores os adquirem concomitantemente. Eles foram expressos semanalmente, bem como as capturas. Na Tabela 29 são apresentados os custos de embarcações de alumínio e dos sistemas de propulsão das pescarias do Complexo de Urubupungá (Ceregato, 2001), Salto Santiago e Salto Osório (Okada et al., 1997), Porto Rico e Porto São José (Carvalho, 2008) e da represa Billings (Petrere et al., 2006). Ao se extrapolar os dados destes sistemas, calculando os custos semanais, é possível observar valores próximos obtidos no presente estudo e no Complexo de Urubupungá, embora o tempo de vida útil apontado em Barra Bonita tenha sido superior.

Petrere et al. (2006) mencionam que na represa Billings a manutenção dos equipamentos (a) é realizada pelos próprios pescadores; (b) é realizada por alguém contratado para este fim, e (c) não é realizada nunca, e na represa de Barra Bonita os pescadores mencionaram como forma de manutenção apenas o item (a). 
Tabela 29: Comparação entre os custos fixos da pesca em Barra Bonita e outras represas do Rio Tietê do Brasil.

\begin{tabular}{l|l|l|l|l|l}
\hline Sistema & Autor & Período & $\begin{array}{l}\text { tmédio (vida útil, } \\
\text { anos) }\end{array}$ & Cf (R\$) & $\begin{array}{l}\text { Cfmédio } \\
\text { estimado* }\end{array}$ \\
\hline Barra Bonita & $\begin{array}{l}\text { Presente } \\
\text { estudo }\end{array}$ & Semanal & 11,1 & 9,12 a 13,18 & 11,15 \\
\hline Complexo de Urubupungá & $\begin{array}{l}\text { Ceregato } \\
(2001)\end{array}$ & Diário & 10,6 & 1,02 a 2,48 & 12,25 \\
\hline $\begin{array}{l}\text { Salto Santiago e Salto } \\
\text { Osório (PR) }\end{array}$ & $\begin{array}{l}\text { Okada et al. } \\
(1997)\end{array}$ & Diário & 8 & 1,92 a 5,03 & 24,33 \\
\hline $\begin{array}{l}\text { Porto Rico e Porto São } \\
\text { José (SP) }\end{array}$ & $\begin{array}{l}\text { Carvalho } \\
(2008)\end{array}$ & Mensal & - & 25,99 a 27,53 & 6,69 \\
\hline Billings & $\begin{array}{l}\text { Petrere et al } \\
(2006)\end{array}$ & Anual & 5,3 & $1862,50+1,78$ & 35,85 \\
\hline
\end{tabular}

* Valor estimado a partir da soma do custo médio da embarcação+custo médio do sistema de propulsão

Os custos variáveis foram expressos em função do gasto com combustível e, eventualmente, gelo para conservação do pescado e remuneração de ajudante. A maior parte dos pescadores afirmou receber o gelo do peixeiro e os que adquiriam gelo de outras fontes não estimavam os custos de combustível e gelo separadamente. Além disso, os pescadores que afirmaram armazenar seu pescado em freezers não conseguiam estimar os custos de conservação do pescado neste.

Petrere et al. (2006) mencionaram que os intermediários fornecem o combustível aos pescadores da represa Billings e que este perfaz a maior parcela de seus custos. Nos estudos sobre as pescarias do Complexo de Urubupungá (Ceregato, 2001) e da região do Médio rio Madeira (AM) (Cardoso \& Freitas, 2006), os custos médios de combustível e de gelo foram próximos. De fato, o gasto com insumos corresponde à maior parcela dos custos dos pescadores de Barra Bonita, apesar da menção ao pequeno percurso percorrido para as pescarias e estes valores elevados podem ser explicados (i) pela dependência do pescador em relação ao intermediário para aquisição do combustível, cujo valor seria elevado, pois nele estariam embutidos os custos de repasse e (ii) ao mau planejamento das pescarias, estando as distâncias percorridas subestimadas.

Os peixes como o dourado e o pacu garantiram retornos econômicos mais elevados, mas tiveram pequena participação na composição da captura. Assim, espécies como a tilápia, mandi e corvina, cujos retornos são cerca de cinco vezes inferiores aos das duas espécies citadas, tiveram maior participação na atividade pesqueira da represa de Barra Bonita. Atualmente a captura de tilápias também sustenta pescadores das represas de Barra Bonita (Maruyama, 2006), Billings (Minte Vera, 1997; Petrere et al., 2006), Lago Paranoá (Walter, 
2000; Petrere, op.cit), dos açudes da região Nordeste do Brasil (Fernando \& Holčík, 1985), além de ter importante contribuição em capturas de reservatórios africanos (Fernando et al.,1998; Goudswaard et al., 2002). Apesar de sua introdução em caráter experimental ainda na metade do século XIX, somente em 1971 o DNOCS (Departamento Nacional de Obras Contra as Secas) implantou um programa oficial de produção de alevinos de tilápia para peixamento dos reservatórios públicos da região Nordeste (Figueiredo Jr. \& Valente Jr., 2008). No Estado de São Paulo, sua produção teve início a partir de 1979 e sucesso adaptativo se deve à rusticidade da espécie, hábito onívoro, cuidado parental e alto potencial reprodutivo (Minte-Vera \& Petrere, 2000; Pereira \& Ribeiro, 2003). O sucesso da introdução desta espécie, embora seja reconhecido em âmbito econômico, pode acarretar problemas ambientais devido à sua elevada excreção de fósforo e seu hábito eminentemente onívoro (Pereira \& Ribeiro, op.cit.), favorecendo o crescimento de algas indesejáveis (Starling, 1998). Hickley et al. (2008) consideraram que a introdução de peixes não-nativos em águas quenianas resultou em danos ecológicos, benefícios econômicos e em importantes questões sobre o manejo do estoque pesqueiro. A partir das evidências disponíveis em relação às represas quenianas, os autores concluíram que o estoque de espécies não-nativas era, em geral, equivocado e que a melhor opção seria evitar este tipo de manejo para os recursos pesqueiros

Frente aos perfis de custos e rendas, foi observado que, por vezes, os pescadores da represa de Barra Bonita tiveram déficit em seus retornos econômicos (observar os valores mínimos de renda, Tabela 26). Além disso, a renda declarada pelos pescadores foi cerca de três vezes superior à receita calculada para a captura. Carvalho (2008) menciona que este tipo de desvio seja reflexo da incapacidade de planejar a atividade e controlar os ganhos, especialmente devido ao declínio das capturas, à vulnerabilidade aos desvios nos custos e renda devido à heterogeneidade da atividade e oscilação nas capturas, impedindo os pescadores de acumular renda para o período de defeso. Carvalho (op.cit) ainda ressalta o preconceito em relação ao valor do salário mínimo no Brasil, montante recebido durante o período de defeso.

A atividade é importante para a economia porque o setor congrega um grande número de trabalhadores ao redor do mundo $(F A O, 2008)$ que dependem das pescarias para seu sustento financeiro e alimentar, além de possibilitar o emprego de outras pessoas que não detentoras dos meios de produção. As pescarias podem não diminuir a pobreza, pois os 
lucros são pequenos ou inexistentes, mas representam um resgate à dignidade devido à sua importância para os pescadores (Carvalho, 2006).

O grau de instrução foi o único fator estatisticamente determinante nos lucros as pescarias de Barra Bonita, e o aumento da idade, do tempo de experiência e do esforço de pesca também possibilitaram um incremento nos lucros, embora não tenham sido estatisticamente significativos. A partir desta análise é possível comprovar que um dos entraves para os avanços da atividade é a falta de educação formal, e que o divisor de águas deste problema está nos níveis mais básicos do grau de instrução (neste caso, os pescadores que haviam cursado até o Ensino Médio Completo obtiveram renda inferior apenas ao pescador que havia cursado Ensino Superior Completo). A deficiência na educação formal dos pescadores impossibilita o planejamento da atividade e que as políticas de manejo sejam conhecidas e respeitadas (Lucato, 2006). As pescarias estudadas por Ceregato \& Petrere (2001) dependeram do petrecho e da arte de pesca utilizada e do grau de instrução. A comparação entre as pescarias da represa Billings (SP) e do Lago Paranoá (DF) indicou que o fator decisivo para seu lucro foi o esforço, expresso em número de idas de pescaria. Os baixos níveis educacionais podem ser causados pela necessidade do ingresso na atividade em idade escolar, comprometendo os estudos dos pescadores.

Em relação aos métodos de análise bio-econômica, o método proposto por Frossard (2003) não se aplica às pescarias artesanais de Barra Bonita. O Método ABC está baseado na identificação das atividades - "consumo de recursos para produzir um produto ou serviço" (Ching, 1995) - para obtenção do produto, e não somente na produção propriamente dita. Dito isto, e frente à simplicidade da cadeia de produção do pescado de Barra Bonita (que não envolve nenhum topo de beneficiamento do pescado, por exemplo), percebe-se que este método em todas as suas especificidades, envolvendo as atividades, os direcionadores de custo e os objetos de custeio, não pode ser aplicado às pescarias aqui estudadas.

O modelo proposto por Matos (2004), apesar de ter como pressupostos diversidade de espécies e petrechos de pesca, as variações sazonais das capturas, o processo de comercialização, como descritos neste estudo, também não pôde ser aplicado aos dados das pescarias de Barra Bonita devido à indisponibilidade de dados específicos do estoque pesqueiro, como mortalidade e o número de indivíduos em determinada classe de idade, que são pré-requisitos para sua aplicação. Existe uma lacuna também nos processos que envolvem e determinam o mercado das pescarias artesanais de Barra Bonita 


\section{CAPÍTULO 5}

\section{MANEJO DOS RECURSOS PESQUEIROS}

\subsection{CONSIDERAÇÕES INICIAIS}

No Brasil, as pescarias artesanais fornecem proteína de boa qualidade, geram ganhos e empregos, apesar dos baixos ganhos e do status social (Camargo \& Petrere, 2001; Ceregato \& Petrere, 2003).

De acordo com a FAO (2008), as políticas de desenvolvimento e manejo das pescarias artesanais devem ser focadas tanto nas pessoas e suas comunidades, como nas questões clássicas dos recursos pesqueiros e de manejo. Estas políticas devem se basear nas complexidades das pessoas e das comunidades envolvidas na pescaria, visando (a) garantir segurança alimentar; (b) minimizar/evitar a vulnerabilidade à pobreza; (c) garantir apoio especial às mulheres envolvidas na pesca; (d) incentivar os direitos; (e) garantir acesso a saúde e educação; (f) garantir acesso a crédito, e (g) criar oportunidades de emprego alternativas.

Segundo Mendonça \& Valêncio (1999), a construção da represa de Barra Bonita teve papel importante no processo de interiorização paulista, com proposta de desenvolver a região, apesar dos problemas sócio-ambientais gerados.

Agostinho et al. (2004) atribuem os insucessos do manejo de reservatórios à escassez de informações, limitações de recursos financeiros e humanos e, a falta de monitoramento. 
Castro (2009) acredita no co-gerenciamento para livrar os pescadores, principalmente das regiões do Médio e Alto Rio Tietê, da condição de precariedade, tanto no modo de vida quanto na atividade pesqueira.

\subsection{OBJETIVOS}

- Discutir as possíveis ferramentas para o manejo dos recursos pesqueiros da represa de Barra Bonita à luz das abordagens discutidas anteriormente (Capítulos 2, 3 e 4), considerando os anseios dos pescadores aqui abordados.

\subsection{METODOLOGIA}

Os questionamentos sobre os problemas enfrentados e perspectivas de resoluções foram analisados descritivamente (Pereira, 2005).

\subsection{RESULTADOS}

O principal problema enfrentado foi a falta de fiscalização das pescarias de Barra Bonita ( $n=60)$, seguido dos fatores físiográficos e ambientais da represa $(n=34)$ e da falta de infraestrutura ( $n=23$ ) (Figura 38).

Partindo da observação da redução do estoque pesqueiro (n=91) (Figura 39A), os pescadores apontaram como possíveis causas a pesca excessiva $(n=92)$, a poluição $(n=18)$ e o uso de redes com abertura de malha inferior à permitida por lei ( $n=10)$ (Figura 39B), lembrando que para indicação das causas, bem como dos problemas descritos, os pescadores podiam apontaram mais de um item. 


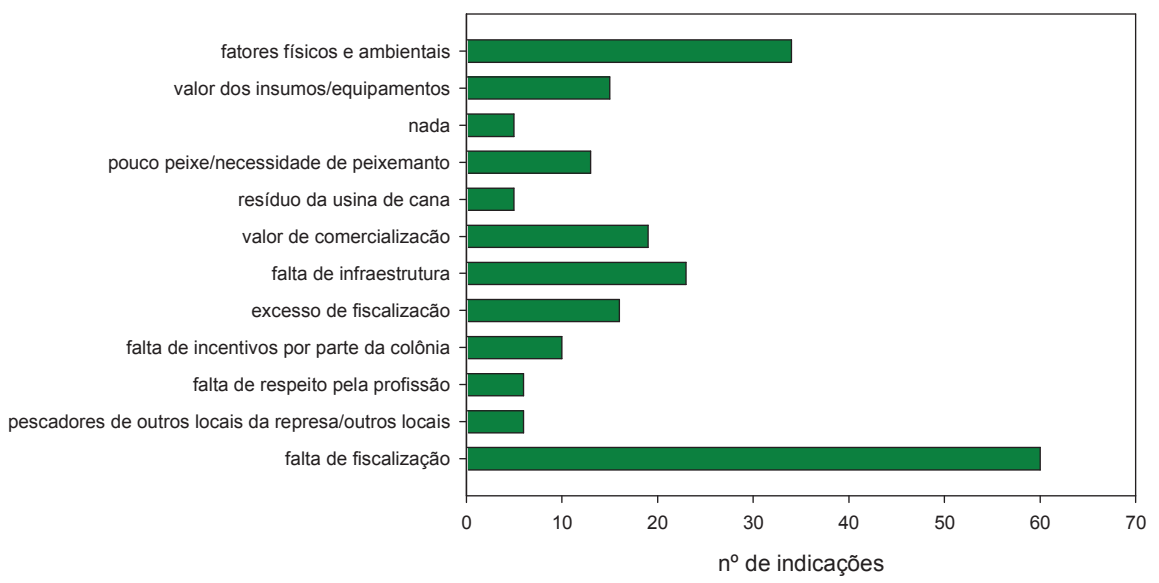

Figura 38: Problemas enfrentados pelos pescadores da represa de Barra Bonita.

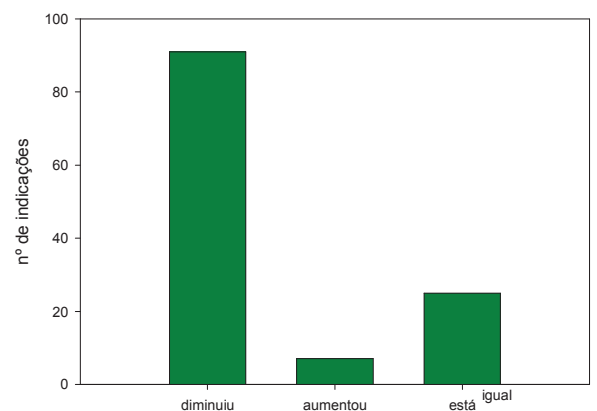

A

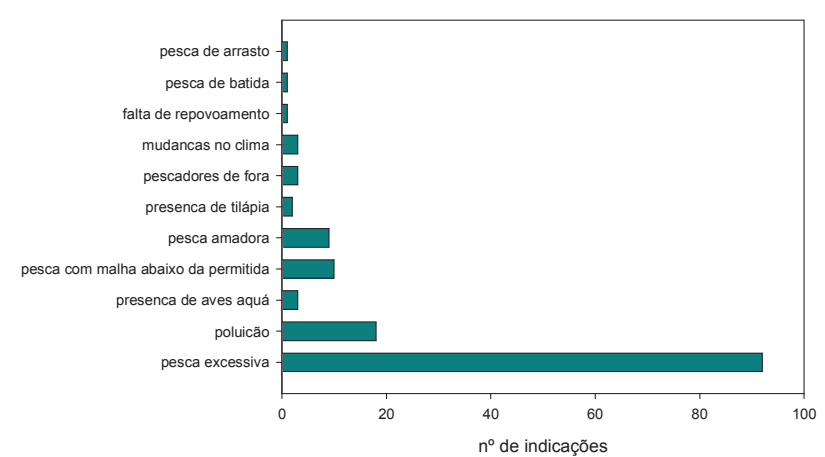

Figura 3939: (a) Situação do estoque pesqueiro da represa de Barra Bonita à época do estudo, e (b) Motivos para a redução.

Para incrementar seus rendimentos, os pescadores mencionaram a prestação de serviços de piloto/guia a pescadores esportivos $(n=7)$, a venda de pescado $(n=3)$ e 17 pescadores afirmaram prestar serviços sem especificar o tipo (Figura 40).

A quase totalidade $(n=95)$ dos pescadores afirmou pertencer à Colônia de Pescadores Z-20 de Barra Bonita, embora houvesse pescadores filiados a outras Colônias ( $\mathrm{n}=11$ ) e outros não filiados a nenhuma Colônia $(n=10)$. Os entrevistados acreditavam que a criação de uma Associação ou Cooperativa poderia trazer algum benefício à pesca ou a eles próprios ( $n=106)$, enquanto 17 deles não viam melhoria na implantação deste tipo de organização. Eles viam numa possível implantação e possibilidade de obter maior retorno econômico $(n=39)$, melhoras nas condições de vida do pescador e valorização da atividade $(n=29)$ e acreditavam na facilidade para aquisição de insumos e equipamentos para as pescarias $(n=23)$. Dentre os 
que não viam benefício nenhum, a maior menção foi na desconfiança em relação aos possíveis membros da Associação (n=23) (Figura 41).

Frente aos fatores que regem as pescarias artesanais, os pescadores afirmaram não desejar que seus filhos continuassem na pesca por acreditar que as condições de vida não são favoráveis e almejavam um futuro melhor para seus filhos $(n=46)$. Eles desejavam ainda que seus filhos tivessem acesso a estudo $(n=30)$ como forma de alcançar melhores empregos. Apenas 12 pescadores almejavam ter um filho atuando junto de si (Figura 42).

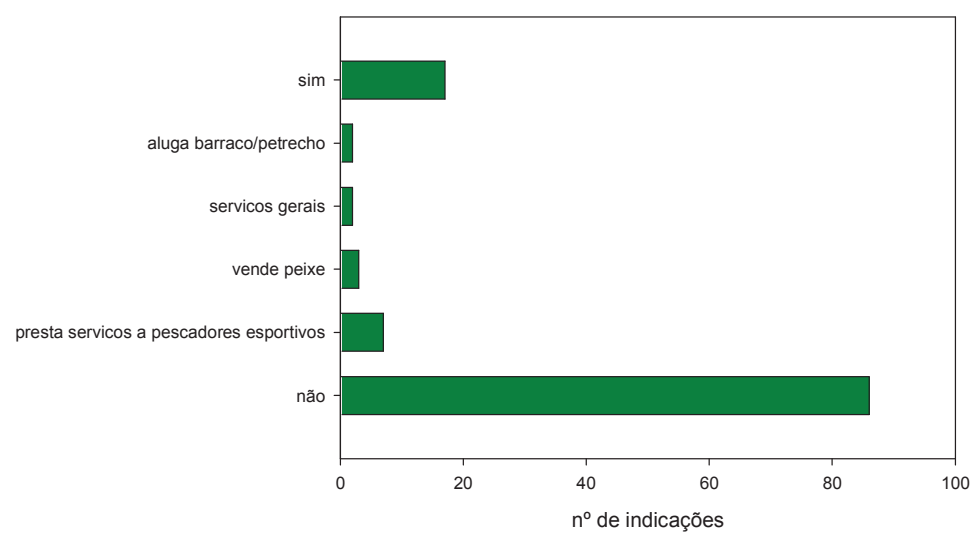

Figura 40: Prestação de serviços a pescadores esportivos da represa de Barra Bonita.

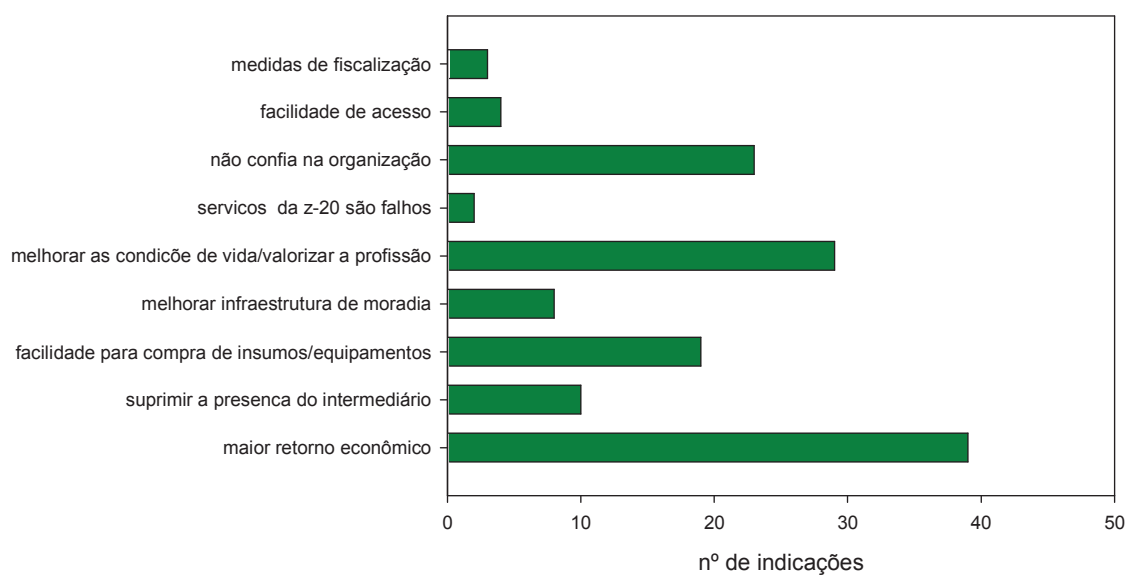

Figura 40: Possíveis benefícios advindos da criação de uma Associação ou Cooperativa às margens da represa de Barra Bonita 


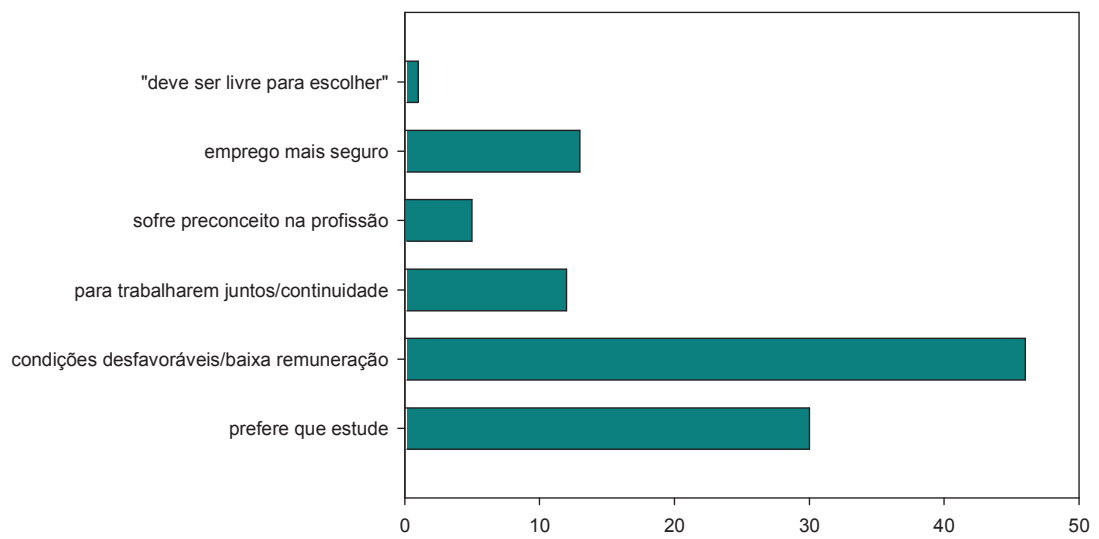

Figura 41: Anseios dos pescadores da represa de Barra Bonita para a geração futura

\subsection{DISCUSSÃO}

O conhecimento empírico do pescador em relação ao ambiente é um fator de suma importância (COPESCAL, 2003) frente ao novo paradigma - Biomanipulação - para manejo de recursos pesqueiros e incorpora uma visão abrangente do sistema de pesca, envolvendo o ambiente, o pescador e o peixe (Agostinho et al., 2004).

Assim, ao considerar como problema para suas pescarias a falta de fiscalização, o pescador não só demonstra incorporar as práticas de manejo vigentes, baseadas na adoção do controle dos petrechos de pesca, mas também questiona a distribuição/territorialidade dos pescadores artesanais e esportivos. Como visto anteriormente, os pescadores de Barra Bonita indicaram não haver escolha quanto aos locais de captura entre seus pares, mas a observação da problemática levantada aqui revela os conflitos entre os pescadores artesanais e esportivos, cada vez mais freqüentes nos rios e represas do Estado de São Paulo (Castro, sem data).

A indicação do declínio das capturas e sua atribuição à pesca excessiva pode ser equivocada. Castro (sem data) menciona os impactos antrópicos nas Bacias Hidrográficas como fatores contribuintes para este declínio e acredita que, tomadas as devidas medidas para minimizar estes impactos, a integração ente os usuários da pesca e os administrados dos recursos pesqueiros promoveria um sistema de co-gerenciamento. Partindo do pressuposto que para sua implementação seja necessário o respeito às medidas de ordenamento, e que os pescadores, ao apontar a necessidade de fiscalização já tem os 
conceitos de responsabilidade pelo uso e conservação incorporados ao seu cotidiano, esta poderia ser uma poderosa ferramenta para melhorar a condição dos recursos pesqueiros e de vida dos pescadores de Barra Bonita, tanto em termos quantitativos como qualitativos.

A expectativa em torno da possível criação de uma Associação ou Cooperativa evidencia a necessidade de maiores lucros. Beltrán Turriago (2001) menciona que em países como El Salvador, Equador e Colômbia, a pesca se tornou uma alternativa à falta de trabalho, pois gera lucros imediatos, embora escassos, sem que haja necessidade de investimento, pois existe a possibilidade de atuar como ajudante de pesca. Além disso, a atividade não requer instrução, os envolvidos têm baixos níveis educacionais e existe o anseio que seus filhos tenham acesso ao estudo como forma de se desvencilhar das pescas e, ao seu ver, consequentemente, da pobreza a que estão submetidos.

Hilborn (2007) aponta os indicadores biológicos e econômicos necessários para a criação de políticas de manejo de pesca: (1) histórico de capturas; (2) porcentagem do estoque pesqueiro sobreexplotado; (3) abundância individual das espécies que compõem as capturas; (4) estimativa de rendimento de captura perdido devido à sobrepesca; (5) rendimento econômico; (6) índice de estado trófico; (7) medidas de funcionamento do ecossistema e biodiversidade; (8) quantidade de descarte (by-catch); (9) sustentabilidade; (10) pesca ilegal.

Quirós (2003) vê o manejo de represas mais simples do que de rios e menciona as características das pescarias de represas: (1) Meio ambiente: estável, com habitats simples e recurso utilizado principalmente pela pesca; (2) Peixes: poucas espécies; (3) Pesca: poucas artes de pesca; características de frota artesanal comercial; comunidade de pescadores com características semelhantes entre as represas; poucos locais de desembarque pesqueiro.

Isaac (2000) considera que o desenvolvimento pesqueiro deveria ter como objetivos (1) o crescimento da produção, (2) o crescimento econômico, (3) o aumento da oferta de emprego, (4) o aumento da produtividade, (5) a igualdade social e (6) a sustentabilidade ecológica. Estes elementos são difíceis de conciliar, especialmente se considerarmos soluções exclusivamente "pesqueiras extrativas".

O IBAMA (2007) tem como diretrizes de seu Programa de Administração Pesqueira para Águas Interiores:

(1) Administrar (ordenar) a pesca continental, buscando o desenvolvimento sustentável; 
(2) Desenvolver um processo de ordenamento pesqueiro utilizando as bacias hidrográficas como unidade de planejamento;

(3) Apoiar a administração pesqueira no binômio embasamento técnico/científico e a administração participativa;

(4) Viabilizar a participação dos usuários dos recursos pesqueiros no processo de gestão;

(5) Administrar a pesca continental buscando integrá-la às outras atividades usuárias dos recursos ambientais e que impactam direta ou indiretamente a pesca;

(6) Apoiar técnica e financeiramente projetos de pesquisa, de forma a garantir o aporte de conhecimentos necessários ao ordenamento;

(7) Apoiar o fortalecimento das estruturas organizacionais dos vários usuários dos recursos pesqueiros, possibilitando uma interlocução formal com legitimidade de representar os interesses comuns.

Experiências ao redor do mundo têm apontado para a criação de peixes como uma alternativa às pescarias artesanais. Esta poderia elevar as produções de pescado e os lucros dos pescadores, a exemplo do que ocorreu na China (De Silva, 2001).

A transformação de pescadores tradicionais artesanais em aquicultores poderia transformar valor tradicional em um valor superável pela modernidade (Mendonça \& Valêncio, 2008). A partir de 2003, com a criação da SEAP (Secretária Especial da Aquicultura e Pesca da Presidência da República, atual MPA - Ministério da Pesca e Aquicultura), a proposta de desenvolvimento do setor pesqueiro se fundamentou em três pilares (sob as críticas de Mendonça \& Valêncio (op.cit.):

(1) Sustentabilidade social: houve desconsideração ao modo de vida da pesca e ao conhecimento do ecossistema aqüícola e a capacitação dos pescadores emerge na dissolução da sociabilidade fundada na tradição;

(2) Sustentabilidade econômica; e

(3) Sustentabilidade ambiental

Estes dois últimos, dadas as escalas e riscos atuais trazem maior vulnerabilidade ao setor e ainda está por ser confirmada.

Outros fatores que devem ser ressaltados são (a) o problema da indicação da falta de respeito à profissão, (b) a expectativa de melhorar a condição de vida e valorizar a profissão, e (c) os anseios dos pescadores em relação à continuidade de seus filhos na atividade pesqueira. Eles evidenciam as condições a que os pescadores foram relegados e seu desejo 
de evitar a marginalização da categoria. As políticas de manejo, em especial o co-manejo, deveriam assim considerar também este fator, tendo no pescador seu aliado para a manutenção da atividade e do meio ambiente. 


\section{CAPÍTULO 6}

\section{CONCLUSÕES}

Com base no estudo sobre as pescarias artesanais da represa de Barra Bonita foi possível concluir que:

As pescarias são praticadas por homens, embora haja a participação feminina na atividade propriamente dita;

$>$ Os homens eram jovens (entre 30 e 39 anos) e possuíam baixa escolaridade (Ensino Básico Incompleto), enquanto as mulheres pertenciam à classe etária acima da masculina (40 a 49 anos) e também tinham baixa escolaridade (Ensino Básico Completo);

$>$ Os pescadores eram de outros municípios do Estado de São Paulo e de outros estados e viviam havia pouco tempo às margens da represa (menos de 10 anos), corroborando informações da literatura sobre suas mudanças freqüentes em busca de represas com melhores rendimentos pesqueiros;

> Suas moradias rústicas, embora dispusessem de fornecimento de eletricidade, abastecimento de água e coleta de lixo, e havia queixas quanto à qualidade da água para consumo e aos serviços deficientes de transporte público; 
- As informações sobre as mazelas das quais os pescadores e suas famílias padeciam deixam transparecer a falta de higiene e informação (1: doenças de fácil propagação e contágio: gripe, micose; 2: mal advindo da falta de higiene: problemas dentários);

O uso do ecossistema não se limitava á exploração dos recursos pesqueiros. 0 contato com animais silvestres (capivara, tatu e jacaré) possibilitava sua caça para complementar a dieta dos pescadores, e também houve menção ao uso da vegetação para diversos fins;

Apesar de mencionarem todos os itens alimentares dos questionários como pertencentes à sua dieta, o elevado consumo do pescado capturado pode indicar que o acesso aos itens era oneroso e que este consumo visava complementar sua dieta de maneira barata e eficaz;

A presença do intermediário se deu em várias dimensões: ora era o fornecedor de alimentos, ora de insumos e também de petrechos, já que muitos dos pescadores não faziam distinção entre a figura do intermediário e do patrão. Além disso, houve menção à estreita dependência em relação também à moradia e à provisão de alimentos, atrelando fortemente a produção do pescador ao intermediário;

A principal espécie capturada foi a tilápia e ela tem tido capturas elevadas em outras represas do Brasil, em detrimento das espécies nativas;

O modelo da ANCOVA indicou que a produção pesqueira não teve dependência do esforço empregado. Ela esteve ligada às características fisiográficas e às oscilações de temperatura e nível da água, por exemplo, provocadas pela sazonalidade. Houve diferença no volume de pescado capturado apenas entre as estações seca e cheia no braço do Rio Piracicaba, com as capturas mais elevadas na época chuvosa;

Os estudos sobre os custos das pescarias indicaram que o principal componente é o combustível, apesar dos pescadores terem mencionado percorrer pequenas distâncias para suas pescarias;

Os lucros são provenientes das abundantes capturas de tilápias. Embora esta espécie não alcance alto valor de comercialização, a constância nas capturas assegura os rendimentos dos pescadores;

Quase todas as embarcações eram de alumínio e apesar de serem mais onerosas para aquisição, tem tempo de vida útil maior e a manutenção era realizada pelos próprios pescadores, embora não tenham conseguido estimar os custos de 
manutenção do equipamento. A pesca com rede de espera foi predominante e, associada ao seu baixo custo de aquisição, o custo de manutenção também foi baixo;

$>$ Os lucros foram baixos e dependeram apenas do grau de instrução dos pescadores. Aqueles que haviam concluído o Ensino Médio tiveram lucros maiores do que os que possuíam menor grau de instrução, exceto quando comparado ao pescador que possuía Ensino Superior, que teve lucros maiores.

$>$ Os modelos econômicos que seriam testados não se mostraram aplicáveis à realidade das pescarias de Barra Bonita devido à insuficiência dos dados obtidos neste estudo;

> Os pescadores indicaram o declínio do estoque pesqueiro e acreditam que, se houvesse fiscalização eficiente, as pescarias predatórias (com petrechos fora dos padrões permitidos por lei) poderiam ser coibidas.

Segundo a hipótese proposta inicialmente neste estudo, as pescarias de Barra Bonita teriam lucro intermediário em relação à represa Billings e no Complexo de Urubupungá. Os pescadores da represa Billings tinham ganho diário de $\mathrm{R} \$ 17,75$ e pescavam tilápias com redes de espera (Petrere et al., 2006). Os ganhos dos pescadores de Urubupungá oscilaram entre $R \$ 13,19$ e $R \$ 19,54$ e na composição de suas capturas havia predominância de espécies nativas (Ceregato \& Petrere, 2003). As rendas semanais dos pescadores de Barra Bonita oscilaram entre $R \$ 231,52$ e $R \$ 480,72$, ou seja, $R \$ 33,07$ a $R \$ 68,67$ diários (para a estação seca e chuvosa, respectivamente). Aparentemente as pescarias de Barra Bonita proporcionam lucros superiores aos provenientes das outras duas represas. 


\section{BIBLIOGRAFIA}

Agostinho, A.A., Okada, E.K., Gregoris, J. (1994) Características econômicas e sociais das atividades pesqueiras no reservatório de Itaipu. In: Simposio regional sobre manejo de la pesca en embalses en América Latina. FAO/ COPESCAL, Havana, 100p. (Publicaciones Técnicas).

Agostinho, A.A.; K.O. Okada; J. Gregoris (1999) A pesca no reservatório de Itaipu: Aspectos sócio econômicos e impactos de represamento. In: Henry, R. (ed.) Ecologia de Reservatório: Estrutura, Função e Aspectos FUNDIBIO/ FAPESP, Botucatu, SP

Agostinho, A.A.; L.C. Gomes; J.D. Latini (2004) Fisheries management in Brazilian reservoirs: lessons from/for South America. Interciencia. v.29 n.6, Caracas, jun. 2004

Agostinho, A.A.; L.C. Gomes; F.M. Pelicice (2007) Ecologia e Manejo de Recursos Pesqueiros em reservatórios do Brasil. Eduem, Maringá. 501p.

AES-TIETÊ. Disponível em: <www.aestiete.com.br>. Acesso em: 12 de janeiro de 2007

ANEEL (Agência Nacional de Energia Elétrica). Disponível em: <www.aneel.gov.br>. Acesso em: 15 de Janeiro de 2006

Barrella, W. \& M. Petrere (2003) Fish community alteration due to pollution and damming in Tietê and Paranapanema rivers (Brazil). River Res. Applic., n.19, p. 59- 76.

Barros, G.S.C \& Machado-Neto, R. (2008) A “velha" e a nova bioeconomia: Desafios para o desenvolvimento sustentável. Disponível em www.cepea.esalq.usp.br. Acesso em $27 / 11 / 2008$ 
Bayley, P.B.; and M. Petrere (1989). Amazon fisheries: assessment methods, current status and management options. Can. Spec. Publ. Fish. Aquat. Sci., 106: 385-398.

Begossi, A.; Garavello, J.C. (1990). Notes on the ethnoichthyology from Tocantins River. Acta Amazonica, Manaus, v. 20, p. 341-351.

Begossi, A; Braga, F.M.S. (1992). Food taboos and folk medicine among fishermen from the Tocantins River (Brasil). Amazoniana, Kiel, v. 12, p. 101-118.

Beltrán Turriago, C.S. (2001) Promoción de la ordenación de la pesca costera. 2. Aspectos socioeconómicos y técnicos de la pesca artesanal en El salvador, Costa Rica, Panamá, Ecuador y Colombia. FAO Circular de Pesca. № 957/2. Roma, FAO. 71p.

Braga, F.M.S. (1997) Biologia reprodutiva de P. squamosissimus (Teleostei, Scianidae) na represa de Barra Bonita, Rio Piracicaba (SP). Revista UNIMAR, v.19, n.2, p. 447-460.

Braga F.M.S. (1998) Alimentação de Plagioscion squamosissimus (Osteichthys, Scianidae) no reservatório de Barra Bonita, Estado de São Paulo. Iheringia Ser. Zool., Porto Alegre, n. 84, p. 11-19.

Braga, F.M.S. (1999) Idade, crescimento e taxas de mortalidade de A. bimaculatus (Characidae, Tetragonopterinae) na Represa de Barra Bonita (SP). Naturalia, São Paulo, n. 24, p. 239-250.

Braga, F.M.S.; Gennari Filho, O (1991) Estudos sobre a fecundidade, desova e mortalidade natural de $M$. intermedia (Characidae, Tetragonopterinae) na represa de Barra Bonita, Rio Piracicaba, SP. Naturalia, São Paulo (16) 55-68.

Calijuri, M.C.; J.G. Tundisi (1990) Limnologia comparada das represas do Lobo (Broa) e Barra Bonita - Estado de São Paulo: mecanismos de funcionamento e bases para o gerenciamento. Rev. Brasil. Biol., São Carlos, v. 50, n.4, p.893-913.

Camargo, S.A.F. (1998). Aspectos de gestão participativa: o caso dos pescadores comerciais do rio São Francisco, MG, Brasil. Dissertação (Mestrado), Centro de Estudos Ambientais, UNESP, Rio Claro

Camargo, S.A.F. \& M. Petrere (2001) Social and financial aspects of the artisanal fisheries of Middle São Francisco River, Minas Gerais, Brazil. Fisheries Management and Ecology, 8: $163-171$ 
Cardoso, R.S., Batista, V.S., Faria Jr., C.H., Martins, W.R. (2004) Aspectos econômicos e operacionais das viagens da frota pesqueira de Manaus, Amazônia Central. VOL. 34(2): $301-307$

Cardoso, R.S., Freitas, C.E.C. (2006). A composição dos custos de armação e a renda das expedições de pesca da frota pesqueira artesanal da região do médio rio Madeira, Amazonas, Brasil. Acta Amazonica vol. 36(4): 519 - 524

Cardoso, E.S. (2001) Pescadores artesanais: natureza, território e movimentos sociais. Tese (doutorado). Faculdade de Filosofia, Letras e Ciências Humanas, Departamento de Geografia, Universidade de São Paulo. 143p.

Carvalho Jr., A.A.; S.C. Fontana; A.A. Tecche; E.A. Teodoro. (1995) Aspectos limnológicos e pesqueiros do reservatório da UHE de Barra Bonita (CESP), rio Tietê, São Paulo. In: Encontro Brasileiro de Ictiologia, 11. Campinas resumos: Campinas: PUC/IBC, 1995.

CARVALHO, A.R. (2002A). CONHECIMENTO ECOLÓGICO TRADICIONAL NO FRAGMENTO DA PLANÍCIE DE INUNDAÇÃO DO ALTO RIO PARANÁ: PERCEPÇÃO ECOLÓGICA DOS PESCADORES. ACTA SCIENTIARUM, MARINGÁ, V.24,N.2,P. 573-580.

CARVALHO, A.R. (2002B). CONHECIMENTO ECOLÓGICO NO “VARJÃO” DO ALTO RIO PARANÁ: ALTERAÇÕES ANTROPOGÊNICAS EXPRESSAS NA LINGUAGEM DOS PESCADORES. ACTA SCIENTIARUM, MARINGÁ, V.24,N.2,P. 581-589.

Carvalho, A.R. (2008) Profits and social performance of small-scale fishing in the Upper Paraná River foodplain (Brazil). Braz. J. Biol., 68(1): 87-93, 2008

Castro, A.C.L. (1994) Ictiofauna do reservatório de Barra Bonita-SP: aspectos ecológicos da comunidade e dinâmica populacional da corvina Plagioscion squamosissimus (Heckel, 1940) (Pices, Perciformes). Tese (Doutorado) Escola de Engenharia de São Carlos, Universidade de São Paulo, São Carlos, 178p.

Castro, F. (1992) Aspectos ecológicos da pesca artesanal no Rio Grande à jusante da usina hidrelétrica de Marimbondo. Dissertação (Mestrado) Instituto de Biologia, UNICAMP, Campinas (SP),

Castro, P.M.G. (sem data) A pesca artesanal profissional extrativista continental no Estado de São Paulo: uma análise crítica. Disponível em <ftp://ftp.sp.gov.br/ftppesca/pesca_artesanal.pdf> acesso em 26/10/2009 
Castro, P.M.G.; Maruyama, L.S.; Bezerra de Menezes, L.C.; Mercante, C.T.J. (2006) Perspectiva da atividade pesqueira no Alto Tietê: contribuição à gestão dos usos múltiplos da água. B. Inst. Pesca, São Paulo, 32(1): 1-14.

Castro, P.M.G. (2009) Gestão participativa da pesca continental paulista: uma saída viável para resolver os problemas da atividade. Disponível em http://www.pesca.sp.gov.br/textos tecnicos.php. Acesso em 6/10/2009.

Ceregato, S.A. (2001) Comparação bioeconômica das pescarias artesanais realizadas no Complexo de Urubupungá e à sua jusante no rio Paraná. Tese (Doutorado). Centro de Estudos Ambientais, UNESP, Rio Claro, 129p.

Ceregato, S.A. \& M. Petrere (2003) Financial comparisons of the artisanal fisheries in Urubupungá Complex in the middle Paraná River (Brazil) Braz. J. Biol., 63 (4): 673-682.

CETESB (2001) Relatório de qualidade das águas interiores de estado de São Paulo. v.2, São Paulo, CETESB, $138 \mathrm{p}$.

Ching, H.Y. (1995) Gestão Baseada no Custeio por Atividade - Activity Based Management. São Paulo; Atlas

Costa F.E.S. \& Braga, F.M.S. (1993) Estudo da alimentação natural de A. bimaculatus, A. schubarti e $M$. intermedia (Characidae, Tetragonopterinae) na represa de Barra Bonita, rio Piracicaba (SP). Revista UNIMAR, v.15, n.2, p. 117-134.

COPESCAL (2003) Comisión de Pesca Continental para América Latina. Exame de la Situación y Tendencias de la Pesca Continental y la Acuicultura en América Latina. Nóvena Sesión. San Salvador, El Salvador, 28-31 de enero del 2003.

De Silva, S (2001) Reservoir Fisheries: Broad Strategies for Enhancing Yields. In: De Silva, S. (ed.) Reservoir and culture-based fisheries: biology and management. Proceedings of an International Workshop held in Bangkok, Thailand from 15-18 February 2000. ACIAR Proceedings No. 98. 384pp.

Eid, F., R.A. Scopinho \& A.E.Pimentel (1998) A dinâmica recente da organização social e produtiva em cooperativas de reforma agrária. Anais do XXXVI Congresso Brasileiro de Economia e Sociologia Rural, Poços de Caldas - MG. p. 767-778

FAO (2006) Informe de la Consulta de Expertos sobre los Procesos de Regulación del Acceso a la Pesca y la Sostenibilidad de las Pesquerías en Pequeña Escala en América Latina. Lima, Perú, 9-12 de mayo de 2006. FAO Informe de Pesca. No. 803. Roma, FAO. 23p. 
FAO. (2009b) Small-scale fisheries - Web site. Small-scale fisheries. In: FAO Fisheries and Aquaculture Department [online]. Rome. Updated 24 July 2007. [Cited 15 January 2009]. http://www.fao.org/fishery/ssf/en

FAO. (2009c) Small-scale fisheries - Web site. People and communities. In: FAO Fisheries and Aquaculture Department [online]. Rome. Updated 24 July 2008. [Cited 14 May 2009]. http://www.fao.org/fishery/ssf/people/en

FAO (2009a). Global Production Statistics 1950-2007. Disponível em http://www.fao.org/fishery/statistics. Acesso em 20/01/2009

FAO. 2007. Gender policies for responsible fisheries - Policies to support gender equity and livelihoods in small-scale fisheries. New Directions in Fisheries - A Series of Policy Briefs on Development Issues, No. 06. Rome. 8 pp. Disponível em: http://www.sflp.org/briefs/eng/policybriefs.html Acesso em 13/9/2008

FAO: INFOFISH, INFOPÊCHE, INFOSA, INFOPESCA (2008) Present and future markets for fish and fish products from small-scale fisheries - case studies from Asia, Africa and Latin America. FAO Fisheries Circular. No. 1033. Rome, FAO. 2008. 87p.

Fernando, C.H., Gurgel, J.J.S., Moyo, N.A.G. (1998). A global view of reservoir fisheries. Internat. Rev. Hydrobiol. (83) 31-42.

Fernando, C.H., Holčík, J. (1985). The nature of fish communities, an important factor influencing fishery potential and yields of lake and reservoirs: A short summary of the concept and its application. Verh. Internat. Verein. Limnol., 22: 2498-2501

Figueiredo Jr., C.A. \& A.S. Valente Jr. (2008) Cultivo de tilápias no brasil: origens e cenário atual. XLVI Congresso Brasileiro de Economia, Administração e Sociologia Rural. $20 \mathrm{~s}$ 23 de julho de 2008. Rio Branco, AC.

Freitas, C.E.C. \& M. Petrere (2001) Influence of artificial reefs on fish assemblage of the Barra Bonita reservoir (São Paulo, Brazil). Lake and Reservoirs: Research and Management, 6, 273-278

Frossard, A.C.P. (2003) Uma contribuição ao estudo dos métodos de custeio tradicionais e do método baseado nas atividades $(A B C)$ quanto à sua aplicação numa empresa pesqueira cearense para fins de evidenciação de resultado. Dissertação (Mestrado). FEA/ USP, 220p. 
Fonteles Filho, A.A. (1989) Recursos Pesqueiros: biologia e dinâmica populacional. Imprensa Oficial do Ceará

Futemma, C.R. \& C.S. Seixas (2008) Há territorialidade na pesca artesanal da Baía de Ubatumirim (Ubatuba, SP)? Questões intra, inter e extra-comunitárias. Revista Biotemas, 21 (1): 125-138, março de 2008

Gama, C.S.; Halboth, D.A. (2004) O problema da criação de Tilápia no Estado do Amapá. In: XXV Congresso Brasileiro de Zoologia, 2004, Brasília. Resumos do XXV Congresso Brasileiro de Zoologia, 2004.

Gennari, O. \& Braga, F.M.S. (1996) Fecundidade e desova de A. bimaculatus e A. schubarti (Characidae, Tetragonopterinae) na represa de Barra Bonita, Rio Piracicaba (SP). Revista UNIMAR, n.18 (2), p. 241-254.

Goudswaard, P.C., Witte, F, Katunzi, E.F.B. (2002). The tilapiine fish stock of Lake Victoria before and after the Nile perch upsurge. Journal of Fish Biology, 60: 838-856.

Gulland, J.A. (1954) A note on the statistical distribution of trawl catches. Rapport et process-verbaux des réunions du Conseil International pour I'Exploration de la Mer, vol. 140 , no. 26 , p. $28-29$

Gulati, R.D. (2001). Manipulação das populações de peixes visando à recuperação de lagos eutrofizados em regiões temperadas. In: BERNARDI, R. \& G. GIUSSANI (eds.) Diretrizes par o gerenciamento de lagos e reservatórios

Hannesson, R. (1993) Bioeconomic analysis of fisheries. Fishing New Books, Oxford

Hickley, P., M. Muchiri, R. Britton, and R. Boar (2008) Economic Gain versus Ecological Damage from the Introduction of Non-native Freshwater Fish: Case Studies from Kenya. The Open Fish Science Journal, 2008, 1, 36-46

Hilborn, R. (2007) Managing fisheries is managing people: what has beenlearned? Fish and Fisheries, 2007, 8, 285-296

HOLČíK, J. (1991). FISH INTRODUCTIONS IN EUROPE WITH PARTICULAR REFERENCE TO ITS CENTRAL AND EASTERN PART. CAN. J. AQUAT. SCI. VOL. 48, 13-23.

Huitema, B.E. (1980) The analysis of covariance and alternatives. John Wiley \& Sons. 445p.

IBGE (2000) Banco de dados SIDRA. Diponível em http://www.sidra.ibge.gov.br/. Acesso em $\underline{25 / 3 / 2010}$ 
IBAMA (2007). Estatística da Pesca. Grandes Regiões e Unidades de Federação. Coordenação Geral de Autorização de Uso da Fauna e Recursos Pesqueiros -- CGFAP. 113p

IBAMA (2007). Pesca continental. Seminário sobre fauna aquática e o setor elétrico brasileiro; gerenciamento de bacias hidrográficas e a fauna aquática, Piranhas, AL, 21-22 setembro, 1994 /Comitê Coordenador das Atividades de Meio Ambiente do Setor Elétrico -COMASE. - Rio de Janeiro: ELETROBRÁs, 1995.

IBAMA/DNOCS/GTZ (1992) Técnicas para um Diagnóstico Rural Rápido voltado para Comunidades Pesqueiras. Documento № 4, Projeto Aproveitamento Pesqueiro dos Açudes do Estado do Ceará, PAPEC, Fortaleza (CE), 40p.

Isaac, V.J.; M.L. Ruffino \& D. McGrath (sem data) The experience of community-based management of middle Amazonian fisheries $<$ ww.indiana.edu/ iascp/Final/isaac.pdf> acesso em 29/3/2010

Isaac, V.I. (2000) Gerenciamento pesqueiro: do planejamento à administração. Reflexões sobre a política de gerenciamento pesqueiro no Brasil com ênfase no exemplo da Amazônia. Instituto de Pesca/APTA/SAA. Sér. Relat. Téc. N. 03, 2000

Kah-Wai, K. \& A.B. Ali (2001) Chenderoh Reservoir, Malaysia:Fish Community and Artisanal Fishery of a Small Mesotrophic Tropical Reservoir. . In: De Silva, S. (ed.) Reservoir and culture-based fisheries: biology and management. Proceedings of an International Workshop held in Bangkok, Thailand from 15-18 February 2000. ACIAR Proceedings No. 98. 384pp.

Jackson, D.C. \& Marmulla, G (2001) The influence of dams on river fisheries. In: Marmulla, G. (Ed.) Dams, fish and fisheries: Opportunities, challenges and conflict resolution. Series title: FAO Fisheries Technical Paper- T419. 171p

King, M. (1997). Fisheries biology, assessment and management. Fishing New Books

Latini, A.O. (2005) Inventário rápido e identificação de fatores que limitam a dispersão de exóticos: um estudo sobre peixes no médio rio Doce (MG, Brasil). Tese (doutorado) Universidade Estadual de Campinas, Instituto de Biologia/Campinas, SP:

Legendre P. \& L. Legendre (1998) Numerical ecology. Elsevier, New York.

Lucato, L.H.B. (2006) An Improved Mixed-Error Non-Equilibrium Stock-Production Model and its Application to some Brazilian Fish Stocks. PhD (Thesis) University of Southampton. 
Faculty of Engineering, Science \& Mathematics School of Ocean and Earth Science. $147 p$.

Lucena, F.M. (2000) Species interaction in fish stock assessment and management in Southern Brazil: a bio-economic approach. PhD Thesis, University of East Anglia, Norwich, England

Madi, E.F. (1988). Existência de tabus alimentares entre as famílias de pescadores da Represa de Três Marias (MG). In: SIMPÓsIO BRASILEIRO DE ETNOBIOLOGIA E ETNOECOLOGIA, 2, São Carlos. Resumos. São Carlos: UFSCar, p. 114.

Mattos, S.M.G (2004) A bioeconomical analysis of the coastal fishery of Pernambuco State, North-Eastern Brazil. Tese (Doutorado), Instituto de Ciencias del Mar (ICM), Consejo Superior de Investigaciones Científicas (CSIC), Barcelona,293 p.

Marinelli, C.E. (2002). Estrutura da comunidade, habitats e padrões de distribuição da ictiofauna em ecótonos do reservatório do Broa, SP. Dissertação (Mestrado), CRHEA/ EESC/ USP, São Carlos, SP

Maruyama, L.S. (2007) A pesca artesanal no Médio e Baixo Tietê (São Paulo, Brasil): aspectos estruturais, sócio-econômicos e de produção pesqueira. Dissertação (Mestrado). Instituto de Pesca, São Paulo

Mendonça, S.A.T. \& N.F.L.S Valêncio (2008) O papel da modernidade no rompimento da tradição: as políticas da SEAP como dissolução do modo de vida da pesca artesanal. B. Inst. Pesca, São Paulo, 34(1): 107 - 116, 2008

Mendonça, S.A.T. (2006) A influência do conhecimento tradicional na formulação de políticas públicas: o caso da pesca artesanal do rio São Francisco. Tese (Doutorado) -Escola de Engenharia de São Carlos - Universidade de São Paulo, 2006.

Mendonça, S.A.T. (1999). Pescadores-barrageiros: perfil profissional e condições de vida no interior paulista. Dissertação (Mestrado), Centro de Estudos Ambientais, UNESP, Rio Claro.

Mendonça, S.A.T.; Valencio, N.F.L.S. (1999) Impactos do Processo de Interiorização do Desenvolvimento Paulista Sobre As Condições de Vida e Trabalho do PescadorBarrageiro. Teoria \& Pesquisa, São Carlos, v. 1, n. 24, p. 4-44, 1999.

Minte-Vera, C.V. (1997). A pesca artesanal no Reservatório Billings (São Paulo). Dissertação (Mestrado), Universidade de Campinas (UNICAMP), 
Minte-Vera, C.V. \& Petrere, M. (2000) Artisanal fisheries in urban reservoirs: a case study from Brazil (Billings Reservoir, São Paulo, Metropolitan Region). Fisheries Management and Ecology, 7, 537-549

Murray-Jones, S., Steffe, A.S. (2000) A comparison between commercial and recreational fisheries of surf clam, Donax deltoids. Fisheries Research (44) 219-233.

Okada, E.K., Agostinho, A.A., Petrere, M. (1996) Catch and effort data and the management of the commercial fisheries of Itaipu reservoir in the upper Paraná River, Brazil. In: Cowx, I.G. (ed.) Stock assessment in inland fisheries. Fishing News Books

Okada, E K., Gregoris, J., Agostinho, A.A., Gomes, L.C. (1997) Diagnóstico da pesca profissional em dois reservatórios do rio Iguaçu. In: A. A. Agostinho \& L. C. Gomes, Reservatório de Segredo: bases ecológicas para o manejo. Editora da Universidade de Maringá, Maringá, pp. 293-318.

Paiva, M.P., Petrere, M., Petenate, A.J., Nepomuceno, F.H., Vasconcelos, E.A. (1994). Relationship between the number of predatory fish species and fish yield in large north-eastern Brazilian reservoirs. In: Cowx, I.G. (ed.): Rehabilitation of freshwater fisheries. Fishing News Books.

Peixer, J. (2008) Características e valoração da pesca esportiva, profissional e do turismo da cachoeira de emas, no rio Mogi-Guaçu/SP. Tese (Doutorado). UNESP, Instituto de Biociências, Rio Claro, SP

Pereira, J.M.A. (2005) A atividade pesqueira na represa do Lobo-Broa (Itirapina, Brotas - SP): caracterização e composição da captura. Dissertação (Mestrado), Centro de Recursos Hídricos e Ecologia Aplicada, EESC/ USP, São Carlos, 130p

Pereira, J.M.A.; Ribeiro Filho, R.A. . Efeitos da excreção de tilápias (Tilapia rendalli e Oreochromis niloticus) em reservatórios e viveiros de piscicultura. In: IX Simpósio do Curso de Ciências da Enegenharia Ambiental-, 2003, Itirapina. Bacia Hidrográfica: diversas abordagens em pesquisa. São Carlos, SP: Rima Editora, 2003.

Pet, J.S., Wijsman, J.W.M., Mous, P.J., Machiels, M.A.M. (1995) Characteristics of a Sri Lanka reservoir fishery and consequences for the estimation of annual yield. In: Pet, J.S. (1995) On the management of tropical reservoir fishery. Thesis Wageningen, The Netherlands, 161p.

Pet, J.S., Piet, G.J. (1993). The consequences of habitat occupation and habitat overlap of the introduced tilapia Oreochromis mossambicus and indigenous fish species for fishery 
management in a Sri Lankan reservoir. Journal of Fish Biology, 43 (Supplement A) 193-208

Petesse, M.L. (2006) Caracterização da ictiofauna da represa de Barra Bonita (SP) e adaptação do índice de integridade biótica (IIB). Tese (Doutorado) Instituto de Biociências do Campus de Rio Claro, Universidade Estadual Paulista, 256p.

Petracco, P. (1995) Determinação da biomassa e estoque de nitrogênio e fósforo de Polygonum spectabile Mart. e Paspalum repens Berg. da represa de Barra Bonita (S.P). Dissertação (Mestrado), Centro de Recursos Hídricos e Ecologia Aplicada, Escola de Engenharia de São Carlos, Universidade de São Paulo. São Carlos, 108p.

Petrere Jr., M.; Giacomini, HC.; De Marco Jr., P. (2010) Catch-per-unit-effort: Which estimator is best? Braz. J. Biol., 2010, vol. 70, no. 2, p. 631-637

Petrere Jr., M.; T. Walter; and C.V. Minte-Vera. (2006) Income evaluation of small - scale fishers in two Brazilian urban reservoirs: Represa Billings(SP) and Lago Paranoá (DF) Braz. J. Biol., 66(3): 817-828, 2006

Petrere, M.; A.A. Agostinho; E.K. Okada, E.K.; H.F. Julio Jr.. (2002). Review of the fisheries in the Brazilian portion of the Paraná/ Pantanal basin. In: Cowx, I.G. (ed.) Management and Ecology of Lake and Reservoir Fisheries. Osney Mead: Fishing New Books, UK

Petrere, M. (1996). Fisheries in large tropical reservoirs in South America. Lake and Reservoirs: Research and Management 2: 111-133

Petrere, M. (1989). River fisheries in Brazil: a review. Regulated rivers: Research and Managment. Vol. 4, 1-16.

Petrere, M. (1986) Amazon fisheries II- Variations in the relative abundance of tucunaré (Cichla ocellaris, C.temensis) based on catch and effort data of the trident fisheries. Amazoniana, X (1) 1-13.

Quirós, R. (2003) Principios de ordenación pesquera responsable para grandes ríos en América Latina. Seminario sobre Ordenación Pesquera Responsable en Grandes Ríos y Embalses de América Latina. FAO/FishCode Revista No. 5

Ruffino, M.L. (2006). Desenvolvimento Pesqueiro no Baixo Amazonas. In: Padoch, C.; Ayres, J.M.; Henderson, A. \& Pinedo-Vasquez, M. (eds.). The Diversity, Development and Conservation of the Amazon Floodplain 
Salati, E (2006) Controle de qualidade de água através de wetlands construídos. Artigo disponível em www.fbds.org.br Acesso em 12/12/2009.

Sautchuk, C. E. (2008) Comer a farinha, desmanchar o sal: ecologia das relações pescador(peixe)-patrão no aviamento amazônico. Série Antropologia (Brasília), v. 420, p. 1-17, 2008.

SEAP (2006) Registro Geral da Pesca. Resultados do recadastramento nacional dos pescadores do Brasil. Disponível em: http://200.198.202.145/seap/Jonathan/RGP/VERSAO CD 5.pdf Acesso 28/10/2009

Silva, M.E.P.A (2008) Pescarias de pequena escala no Reservatório Billings (Alto Tietê) nos anps de 2005 a 2007. Dissertação (Mestrado). Instituto de Pesca, São Paulo

Silvano, R.A.M.; A. Begossi (1998) The artisanal fishery of the river Piracicaba (São Paulo, Brazil): fish landing composition and environmental alterations. Ital. J. Zool., n. 65, p. 527-531 Suppl.

Smith, W.S.; E.L.G. Espíndola; C.C. Pereira; O. Rocha (2002) Impactos dos reservatórios do médio e baixo rio Tietê (SP) na composição das espécies de peixes e na atividade de pesca. In: RIMA (Ed). Recursos hidroenergéticos: usos, impactos e planejamento integrado. São Carlos: RiMa Editora, 2002, p.57-72.

Smith, W.S.; C.C. Pereira; E.L.G. Espíndola; O. Rocha (2003) A importância da zona litoral para a disponibilidade de recursos alimentares à comunidade de peixes em reservatórios. In: Henry, R. (Org.). Ecótonos nas interfaces dos ecossistemas aquáticos. São Carlos: RiMa Editora, p.233-248.

Sonoda, D.Y. (2002) Análise econômica de sistemas alternativos de produção de tilápias em tanques redes para diferentes mercados. Dissertação (Mestrado). ESALQ/USP. 77p.

Souza, M.A.A. (2006) Contribuição das políticas públicas na captura, na comercialização e na geração de renda da atividade pesqueira artesanal no Rio Grande do Sul. In: Encontro de Economia Gaúcha, 3., Rio Grande do Sul: PUC. Disponível em: <http://www.pucrs.br/eventos/3eeg/Artigos/m04t04.pdf> Acesso em: 20/01/2010

Starling, F.L.R.M. (1998) Development of Biomanipulation Strategies for the Remediation of Eutrophication Problems in an Urban Reservoir, Lago Paranoá - Brazil, PhD Thesis, Institute of Aquaculture, University of Stirling, Scotland. 242 pp. 
Straškraba, M. \& J.G. Tundisi (2000) Diretrizes para o gerenciamento da qualidade da água de represas. IIE- Instituto Internacional de Ecologia, São Carlos, 258 pp.

SYSTAT Version 11 (2004) SPSS Inc., Demonstration Version.

Thomaz, S. M. Fatores ecológicos associados à colonização e ao desenvolvimento de macrófitas aquáticas e desafios de manejo. Planta Daninha, v. 20, p. 21-33, 2002. Edição especial.

Torloni, C.E.; Correa, A.; Carvalho JR., A.A.; Santos, J.J.; Gonçalves, J.; Gereto, E.; Cruz, J.A.; Moreira, J.A.; Silva, D.C.; Deus, E.F.; Ferreira, A. (1993) Produção pesqueira e composição das capturas em reservatórios sob concessão da CESP nos rios Tietê, Paraná e Grande no período de 1986-1991. São Paulo, Serie: Produção Pesqueira, n. 1

Torres, H.G.; R.M. Bichir; T.P. Carpim (2008) uma pobreza diferente? Mudanças no padrão de consumo da população de baixa renda. Novos Estudos 74. Março 2006

Tundisi, J.G. (1999) Reservatórios como Sistemas Complexos: Teoria, Aplicações e Perspectivas para Usos Múltiplos. In: Henry, R. (ed.) Ecologia de Reservatório: Estrutura, Função e Aspectos FUNDIBIO/ FAPESP, Botucatu, SP

Venturato, R.D. (2008) Desafios do modo de vida da pesca artesanal em água doce num contexto socioambiental adverso: uma análise sociológica do caso do bairro rural do Tanquã, Piracicaba/SP. Dissertação (Mestrado). Centro de Ciências Agrárias, UFSCar.

Venturato, R.D.; N.F.L.F. Valêncio (2008) Desafios do modo de vida na pesca artesanal: comunidadeTanquã, Piracicaba/SP. IV Encontro Nacional da Anppas. Brasília/DF Brasil

Walter, T. (1998) Ecologia da pesca artesanal no Lago Paranoá, Brasília-DF. Dissertação (Mestrado), Escola de Engenharia de São Carlos - Universidade de São Paulo, São Carlos, SP, 230p.

Welcomme, R.L. (1988) International Introductions of Inland Aquatic Species. FAO Fisheries Technical Paper, 294: 318. 
ANEXO 


\begin{tabular}{ll}
\hline FICHA № & Entrevistador: \\
\hline Local: & Data: \\
\hline
\end{tabular}

A. Dados Pessoais

\begin{tabular}{|l|l|}
\hline 1. Nome do pescador & \\
\hline Sexo: ( ) masculino & Estado civil: \\
\multicolumn{1}{|l|}{ ( ) feminino } & 1. solteiro \\
\hline Endereço: & 2. casado \\
\hline Cidade: & 3. divorciado/separado \\
\hline CEP: & 4. viúvo \\
\hline Escolaridade & Idade: \\
\hline
\end{tabular}

2. Dependentes: № de pessoas trabalham: № de pessoas não trabalham:

B. Perfil dos membros da família de cada domicílio

\begin{tabular}{|c|c|c|c|c|c|c|}
\hline 1. Nome & Parentesco & Sexo & Idade & Escolaridade & $\begin{array}{l}\text { Atividade } \\
\text { Econômica }\end{array}$ & Renda \\
\hline & & & & & & \\
\hline & & & & & & \\
\hline & & & & & & \\
\hline & & & & & & \\
\hline & & & & & & \\
\hline & & & & & & \\
\hline & & & & & & \\
\hline & & & & & & \\
\hline & & & & & & \\
\hline
\end{tabular}

2. Os familiares participam da atividade pesqueira?

( ) Não ( ) Sim

1. Também pescam

2. Ajudante de pesca

3. Limpa peixe

4. Vende peixe

5. Outro, especificar:

C. Estrutura domiciliar e urbanidade

1. Há quanto tempo mora neste local?
a. origem (cidade/estado) zona: ( )urbana ( )rural
b. porque se mudou para cá?
c. Sua casa é: ( )própria ( )alugada ( )é caseiro ( )outro

2. Cultiva a terra? (tem horta, pomar, etc.).
( ) não
( ) sim. Área:

3. Cria algum animal?
( ) não
( ) sim. Quais?

4. Indicar os aspectos do lugar: (F) p/ favorável, (D) p/ desfavorável

( ) Proximidade da escola, igreja, comércio

( ) Qualidade da terra para plantio

( ) Qualidade da terra para criação de gado, galinha, porco, etc.

( ) Qualidade do ar 
( ) Qualidade da água para pesca

( ) Qualidade da água para beber, tomar banho, cozinhar, etc.

( ) Facilidade de transporte de ônibus

5. Área construída do domicílio em metros quadrados:

6. Qualidade do domicílio:

\begin{tabular}{|l|l|l|}
\hline Material das paredes & Material do telhado & Material do piso \\
\hline ( )alvenaria & ( ) telha de barro & ( )madeira \\
( )madeira & () madeira & ( ) ladrilho \\
( )adobe & () zinco & ( ) cimento ou tijolo \\
( ) pau a pique & ( )fibrocimento (brasilite) & () terra batida \\
( )outros: & ( )outros: & ( ) outros: \\
\hline
\end{tabular}

7. A família residente no domicílio possui:

\begin{tabular}{|l|l|}
\hline Bens & Quantos? \\
\hline 1. automóvel & \\
\hline 2. motocicleta & \\
\hline 3. bicicleta & \\
\hline 4. televisor & \\
\hline 5. telefone & \\
\hline 6. geladeira & \\
\hline
\end{tabular}

\begin{tabular}{|l|l|}
\hline Bens & Quantos? \\
\hline 7. rádio & \\
\hline 8. máquina de lavar roupa & \\
\hline 9. máquina de lavar louça & \\
\hline 10. microondas & \\
\hline 11. freezer & \\
\hline Utilizado para armazenar peixes da pesca? & ( ) sim ( ) não \\
\hline
\end{tabular}

8. Fonte de energia

( ) Eletricidade da rede

() Lampião/Vela

() outro, citar:

9. Combustível para cocção

( ) gás de botijão

() lenha

( ) carvão

\section{Saneamento básico}

1. O abastecimento da água em sua residência é feito através de:

() rede pública

( ) poço normal, profundidade aproximada $\mathrm{m}$

( ) poço artesiano, profundidade aproximada $\mathrm{m}$

( ) poço semi-artesiano, profundidade aproximada m

( ) do Lago ( reservatório)

( ) rio/córrego

( ) nascente, olho d'água, laguinho

() carro pipa

2. Quanto ao tratamento da água utilizada ela é:
( ) filtrada
() fervida
( ) clorada
() nada
() outro:

3. Seu domicílio possui instalações sanitárias?

( ) Não ( ) Sim

Localização: ( )dentro do domicílio ( ) fora do domicílio 
4. O domicílio é servido por:

() rede geral (esgoto)

( ) fossa séptica ligada à rede pluvial

( ) fossa rudimentar, qual a distância entre esta e o poço? m

() vala

( ) o esgoto é jogado diretamente no curso d'água

( ) outros:

5. Qual é o destino do lixo de seu domicílio?

() coletado por caminhões

() queimado

() enterrado

( ) jogado no Lago

( ) jogado no rio/córregos

( ) outros:

E. Saúde, nutrição e assistência previdenciária (aplicar a todos os membros da família).

1. Há utilização da represa:

( ) para banho (higiene)

() para banho (lazer)

( ) para deposição de resíduo

( ) como fonte eventual de água para alimentação

( ) para higiene e consumo de animais de estimação/ criação

( ) para irrigação de plantas de uso alimentar e animal

2. Qual atendimento à saúde está a sua disposição?
() Hospital particular
() Médico particular
() Hospital público
( ) Médico de serviço público
() Centro de saúde
( ) Farmácia
() Posto de saúde
( ) Benzedeira ou rezadeira
( ) Clínica ou policlínica
() Dentista

3. O chefe da casa tem assistência previdenciária?

() previdência pública

() previdência particular

( ) não possui porque: ( ) não pode por entraves legais
( ) está desempregado (caso tenha outra ocupação)
( ) não necessita de assistência previdenciária
( ) outro:

4. Que doenças/sintomas vocês tiveram nos últimos seis meses?

\begin{tabular}{|l|l|l|l|}
\hline Tipo de doença & Sintomas & Crianças & Adultos \\
\hline Verminose & & & \\
\hline Gripe/resfriado & & & \\
\hline Pneumonia & & & \\
\hline Desidratação & & & \\
\hline Reumatismo & & & \\
\hline Cólera & & & \\
\hline Dengue & & & \\
\hline Leishmaniose & & & \\
\hline Leptospirose & & & \\
\hline Micoses & & & \\
\hline Alergias & & & \\
\hline Subnutrição & & & \\
\hline
\end{tabular}




\begin{tabular}{|l|l|l|l|}
\hline Problemas dentários & & & \\
\hline Outras identificadas & & & \\
\hline Outras não identificadas & & & \\
\hline
\end{tabular}

5. Na área do domicílio é freqüente a incidência de:
() mosca comum
() morcego
() mosca varejeira
() caramujo
( ) pernilongo
() ratos
() barbeiro
() baratas
( )gafanhoto
( ) bicho de pé

6. Os residentes já sofreram ataques de animais peçonhentos?

( ) Não ( ) Sim. Qual?

7. Que animais silvestres existem nesta área? Sua população se mantém estável, vem crescendo ou decrescendo nos últimos anos?

\section{Espécie}

8. Os residentes já sofreram ataques de animais silvestres?
( ) Não
() Sim. Qual?

9. Os residentes servem-se de animais silvestres para consumo de seus subprodutos? (pele, ossos ou carne)
( ) Não
() Sim. Qual?

10. Animais silvestres da região são utilizados ou vendidos pela população local como:
() souvenirs
( ) alimento
( ) bichinho de estimação
( ) não

11. Os residentes servem-se do ecossistema local para utilização em seu estado natural: ornamentais ( para enfeite)

( ) de plantas alimentícias

( ) de plantas medicinais

( ) de plantas para fins combustíveis

( ) de plantas como material de construção

12. A dieta alimentar diária consiste de:
( ) carne vermelha
() carne branca (de ave e de peixe)
() peixe da represa (Freqüência:
() leite e derivados
() farináceos e cereais
( ) arroz
( ) leguminosas (vagem, lentilha)
( ) feijão
( ) verduras e legumes
() frutas /sem, /mês, /ano)

13. A origem dos alimentos hortifrutis consumidos:

( ) produção de subsistência ( produção própria)

() hortas comunitárias

() feiras livres 
( ) supermercados e varejões

( ) outros:

14. A origem dos alimentos de origem protéica:

( ) produção de subsistência (granja e rebanho de consumo próprio)

() açougues

( ) padarias (para laticínios)

() feiras

( ) supermercados

( ) rio/Lago (peixes)

\section{F. Pesca}

1. Há quanto tempo que atua como pescador na represa de Barra Bonita? Em outros locais? Quais?

Pesca em algum rio ou córrego aqui perto?___ Quais?

Tem ajudante de pesca? ( ) não ( )sim, é ( )parente, ( )amigo ou ( ) empregado? Quantos?

2. Quantos dias por semana trabalha? /sem

3. Quantas horas por dia?

4. Gasto de manutenção dos insumos de produção por semana:

5. Gastos com empregado, parceiros, meeiros, etc., por semana:

6. Consome pescado da sua própria produção?

( ) não ( ) sim. Quantos quilos por semana?

7. Num dia normal de pescaria (nem o melhor e nem o pior) quantos quilos pesca no total? $\mathrm{Kg}$

8. Principais peixes capturados:

\begin{tabular}{|c|c|c|}
\hline Espécies & Local de maior incidência & Quanto pescou na última semana \\
\hline & & \\
\hline & & \\
\hline & & \\
\hline & & \\
\hline & & \\
\hline
\end{tabular}

9. Existem locais de pesca pré-determinados para cada pescador?

( ) não ( ) sim. Em que região e por quê?

10. Local onde vende o pescado

1. na represa (barco)/ barranca

2. em casa

3. feira. Onde?

4. outros

11 A quem vende o pescado?

1. atravessador/ peixeiro

2. cooperativa. Onde?

3. colônia de pesca. Onde?

4. varejo. Onde?

5. feira. Onde? 
6. CEASA. Onde?

7. consumidor

8. outros:

12. Qual é o preço que é vendido o quilo do pescado?

\begin{tabular}{|l|l|}
\hline Espécie & Preço R\$/kg \\
\hline & \\
\hline & \\
\hline & \\
\hline & \\
\hline
\end{tabular}

14. Conservação do pescado:

1. a fresco

2. a gelo

3. congelador/freezer

5. outros:

15. Pesca o ano inteiro?

( )sim ( )não, em que época?

16. Quantas pessoas pescam aqui?

17. Equipamento de pesca (quantidade):

\begin{tabular}{|l|l|l|l|l|}
\hline Equipamento & De quem é? & Características & Quanto duram? & Quanto custam? \\
\hline Barco de madeira & & c: & & \\
\hline Tarrafa: & & $\begin{array}{l}\text { malha: } \\
\text { h: }\end{array}$ & & \\
\hline Rede de espera & $\begin{array}{l}\text { malha: } \\
\text { h: } \\
\text { c: }\end{array}$ & & \\
\hline Rede de batida & $\begin{array}{l}\text { malha: } \\
\text { h: } \\
\text { c: }\end{array}$ & & \\
\hline
\end{tabular}

Outros:

( ) espinhel

( ) anzol de espera

( ) linhadas

( ) linha e anzol

( ) fisgas

( ) vara de pescar, no de anzóis

18. Renda mensal bruta da pesca:

19. Outras fontes de renda:

1. proprietário (renda da produção)

2. assalariado (empregado rural ou urbano)

3. renda por serviços prestados (autônomo)

4. renda de juros (poupança, etc.)

5. aposentadoria

6. agricultura

7. artesanato

8. extrativismo

9. venda de peixes de outros pescadores

10. trabalhador da construção civil

11. outros:

20. Quais os problemas que vem enfrentando na atividade pesqueira e quais as sugestões para solucionálas 
21. Acha que o estoque pesqueiro diminuiu?

( ) Não ( ) está igual ( ) Sim. A que atribui esta redução?

1. Pesca excessiva

2. Poluição

3. Pesca amadora

4. Outros:

22. Existe pesca esportiva no entorno?

( ) Não ( ) Sim

Afeta o estilo de vida da população residente?

Afeta a atividade pesqueira?

23. Presta serviço para pescadores amadores, como guia, piloto, etc.? （ ) Sim （ ) Não

24. Pertence a alguma associação?

( ) sim, qual?

( ) não

25. Acha que a situação atual da pesca melhoraria com a implementação de uma cooperativa/ associação? ( ) Não ( ) Sim. Onde?

26. Gostaria que o seu filho continuasse pescando?
() $\operatorname{sim}$
( ) não. Por quê?

OBSERVAÇÕES: 